LUANA PASCHOAL

\title{
A CONDUTA SOCIAL E A PERSONALIDADE DO AGENTE NA FIXAÇÃO DA PENA
}

\author{
Dissertação de Mestrado
}

Orientadora: Professora Associada Helena Regina Lobo da Costa

FACULDADE DE DIREITO DA UNIVERSIDADE DE SÃO PAULO

SÃO PAULO

2014 


\section{A CONDUTA SOCIAL E A PERSONALIDADE DO AGENTE NA FIXAÇÃO DA PENA}

Dissertação apresentada à Faculdade de Direito da USP, na área de concentração de Direito Penal, Medicina Forense e Criminologia para obtenção do título de Mestre.

Orientadora: Excelentíssima Senhora Professora Associada HELENA REGINA LOBO DA COSTA.

FACULDADE DE DIREITO DA UNIVERSIDADE DE SÃO PAULO

São Paulo 


\title{
A CONDUTA SOCIAL E A PERSONALIDADE DO AGENTE NA FIXAÇÃO DA PENA
}

\author{
Dissertação apresentada à Faculdade de Direito da \\ USP, na área de concentração de Direito Penal, \\ Medicina Forense e Criminologia para obtenção do \\ título de Mestre. \\ Orientadora: Excelentíssima Senhora Professora \\ Associada HELENA REGINA LOBO DA COSTA.
}

Aprovada em:

Banca Examinadora

Prof. Dr.

Instituição

Assinatura

Prof. Dr.

Instituição

Assinatura

Prof. Dr.

Instituição

Assinatura 
Dedico este trabalho ao meu filho Gregório, que apesar da pouca idade, melhor que qualquer adulto, soube suportar a minha necessária e dolorosa ausência, as minhas crises de ansiedade e de impaciência; e, ainda assim, continuou torcendo e rezando para que eu conseguisse levar esse projeto até o final. Obrigada por sua compreensão e confiança. Mais, obrigada por ter sido fonte de inspiração para uma parte de especial importância para mim neste trabalho. A que fala sobre Educação. Sem você, não teria sido possível, minha preciosidade! 


\section{AGRADECIMENTOS}

Muito e a muitas pessoas eu tenho a agradecer por este Trabalho.

A primeira pessoa, sem sombra de dúvida, é a minha querida orientadora, Professora Helena Regina Lobo da Costa, quem, além de me confiar uma vaga de Mestrado, realizou um grande e antigo sonho meu - o de estudar na USP. Serei eternamente grata!

Depois, aos meus amados pais, Ricardo e Regina, que são exemplos de dedicação amorosa aos filhos. Obrigada pela educação de caráter!

À minha irmã Janaina, cuja existência pautou grande parte da minha trajetória de vida, qualquer palavra é pouco para agradecer tudo o que você representa para mim.

À minha irmã Nohara, eu agradeço a companhia diária, regada com muita alegria e leveza. Qualquer fardo fica pequeno se você estiver ao meu lado.

Ao meu irmão Jorge, cujo amor é de filho, eu agradeço por todo apoio ao longo desta jornada acadêmica, na qual invertemos os papeis, tamanho o cuidado que você me prestou.

Aos professores da Pós-Graduação, cada um com sua centelha divina, obrigada pela felicidade que me proporcionaram ao longo do curso. Voltar para a Faculdade realmente me trouxe muita alegria!

Um agradecimento especial à Professora Lídia Reis de Almeida Prado, por ter me possibilitado "ser" em sua disciplina. Com você, eu dancei, cantei, ri e chorei. Agradeço imensamente pelo lúdico em suas aulas!

Ao amigo Elio Braz Mendes, obrigada pelo entusiasmo nas aulas, e por compartilhar os meus sonhos. Sem você, não teria tanta graça. E a amiga Grace Menck Figueroa, agradeço pelo incentivo continuo, e pela disposição em sempre ajudar!

Agradeço aos amores da minha vida, meu marido, Marcelo, pelo constante apoio com os cuidados com o filho, em minha ausência; pela paciência e mais paciência, porque se eu já era chata, só piorei nesse período! Meu filho Gregório, pela compreensão e torcida fanática pela conclusão deste projeto! E, por fim, ao meu Mestre Espiritual Sri Prem Baba por ter me orientado a fazer desse Trabalho o meu Karma Yoga! 


\section{RESUMO}

A presente dissertação, concebida a partir do modelo teórico desenvolvido por Luigi Ferrajoli, questiona a previsão da conduta social e da personalidade, do artigo 59 do Código Penal Brasileiro, como critérios orientadores aos magistrados, para fixação da pena-base entre o mínimo e o máximo. A pesquisa abordou o conceito dessas circunstâncias judiciais tanto na Doutrina quanto na Jurisprudência, sendo que o resultado do estudo revelou a excessiva carga moral que ainda orienta sua análise. Aborda-se a falácia do mito da neutralidade judicial, uma vez que não é possível apartar os juízes de sua natural condição de seres humanos, e de seus contextos de vida. Trata da necessária tomada de consciência de que toda decisão está contaminada de subjetividade, por parte daqueles que pretendem exercer a judicatura. E apresenta o Autoconhecimento como única via capaz de controlar a subjetividade nas decisões judiciais, na medida em que a investigação interna acarretará humanização, o confronto com o lado sombrio, e reconhecimento da dualidade convivendo em todos os seres humanos, de modo a demonstrar que ninguém está acima do bem e do mal. A pesquisa ainda demonstrou a incoerência da necessidade de analisar circunstâncias significativamente pessoais e subjetivas dos réus, quando o ser humano cresceu, aprendendo desconsiderar e atropelar qualquer particularidade própria e de outros indivíduos. Para tanto, faz uma análise de digressão aos primeiros anos de vida e aos bancos escolares, em que plantadas as primeiras sementes de desconsideração, e de valorização do externo em detrimento do interno, almejando-se profissões de prestígio, em prejuízo da realização pessoal. Faz uma crítica ao Sistema Judicial Brasileiro, a fim de que assuma seu lado humano, colocando um desafio à Magistratura para buscar aqueles que realmente são vocacionados para a função, fornecendo sugestões de modificações na Formação Jurídica.

PALAVRAS-CHAVE: Artigo 59 do Código Penal. Conduta social. Personalidade. Subjetividade nas decisões judiciais. Neutralidade nas decisões judiciais. Magistratura. Autoconhecimento. Educação. Aspectos psicológicos nas decisões judiciais. Formação jurídica. 


\begin{abstract}
The instant research took into consideration the theoretical model developed by Luigi Ferrajoli, which questions the prediction of social conduct and personality, in Article 59 of the Brazilian Criminal Code, as guiding criteria for judges to determine standards of minimum and maximum sanctions. The research addressed the concept of such legal circumstances both in doctrine and in case law, and the result of the study revealed excessive moral burden that still guides the judges' analysis. This research addresses the fallacy of the myth of judicial neutrality, since it is not possible to separate the judges from their natural condition of human beings and their life contexts. This separation requires awareness that every decision has a subjective component. And introduced the self-knowledge as the only way able to control subjectivity in judgments, as the internal investigation will result in humanization, the confrontation with the dark side, and recognition of duality in all living humans, in order to demonstrate that no one is above good and evil. The survey also showed the inconsistency of the need to analyze so personal and subjective circumstances of the defendant, when human beings were raised, learning to ignore its own and other individuals personal traits. To this end, an analysis of the early years as well as schooling system, where the first ideas of disregard, and enhancement of external rather than internal values arose, targeting prestigious positions, at the expense of personal fulfillment. This research criticizes the Brazilian Judicial System, so that it enhances its human side, posing a challenge to judges to seek those who are really devoted to the function, providing suggestions for changes in the Legal Training System.
\end{abstract}

KEYWORDS: Article 59 of the Brazilian Criminal Code. Social Conduct. Personality. Subjectivity in judgments. Neutrality in judicial decisions. Judiciciary. Self-Knowledge. Education. Psychological aspects in judicial decisions. Legal training system. 


\section{SUMÁRIO}

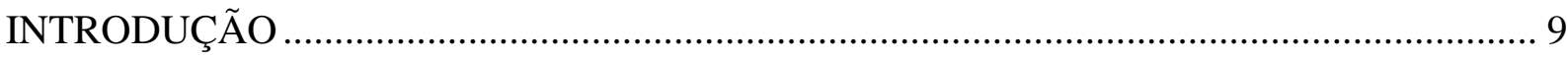

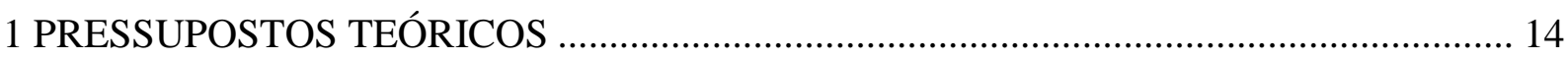

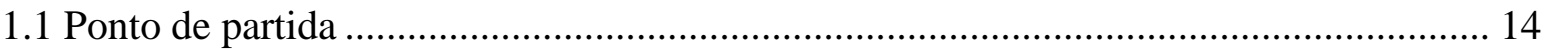

1.2 A nova concepção de delito: do delito pecado para o delito fato e o primeiro passo para uma maior racionalização do poder de punir.................................................................... 19 $1.3 \mathrm{O}$ modelo de Luigi Ferrajoli: legalidade não só na previsão dos delitos, mas também na cominação e aplicação das penas .......................................................................................... 20

2 CIRCUNSTÂNCIAS JUDICIAIS PESSOAIS DO ARTIGO 59 DO CÓDIGO PENAL .... 34

2.1 Breves observações introdutórias sobre as finalidades da pena ...................................... 34

2.1.1 Finalidade retributiva da pena (teorias absolutas) ................................................... 36

2.1.2 Finalidade preventiva da pena (teorias relativas) .................................................... 37

2.1.2.1 Prevenção geral negativa ............................................................................. 39

2.1.2.1.1 Prevenção geral positiva ............................................................................. 43

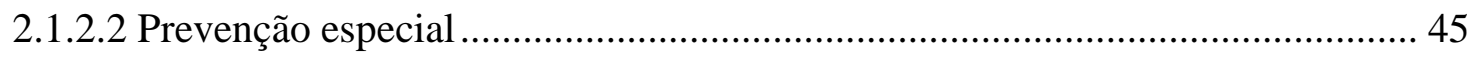

2.1.2.2.1 Prevenção especial negativa .................................................................... 45

2.1.2.2.2 Prevenção especial positiva .................................................................... 46

2.1.3 Teoria eclética (ou unitária) ............................................................................ 52

2.1.4 Teorias abolicionistas e teoria agnóstica ………………........................................ 53

2.2 A contribuição de Luigi Ferrajoli da razão (finalidade preventiva) e do como punir (de

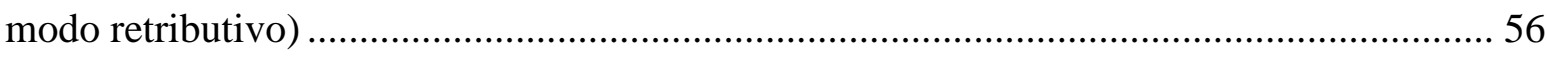

2.3 Finalidades da pena e sua individualização no ordenamento jurídico brasileiro............. 58

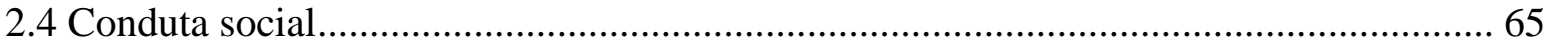

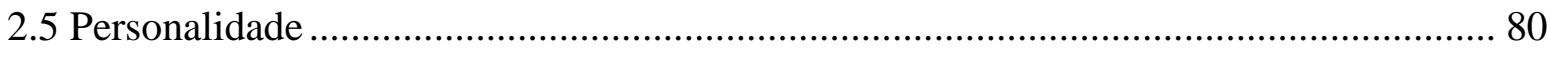

3 Análise de julgados sobre antecedentes, conduta social e personalidade na Jurisprudência

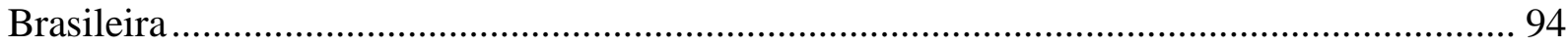

3.1. Análise da Súmula 444 do Superior Tribunal de Justiça .................................................. 94

3.2 Análise do impacto da Súmula 444 do STJ nas decisões do Superior Tribunal de Justiça,

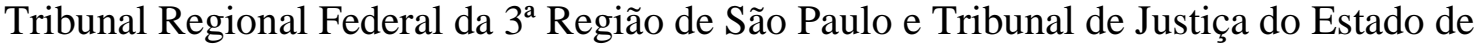
São Paulo. 
3.2.1 Decisões do Superior Tribunal de Justiça ............................................................... 100

3.2.2 Decisões do Tribunal Regional Federal da $3^{\mathrm{a}}$ Região............................................. 102

3.2.3 Decisões do Tribunal de Justiça de São Paulo....................................................... 111

3.3 Análise de julgados com o fim de verificar o que se considera como personalidade e conduta social para fins de aplicação da pena-base acima do mínimo legal ....................... 115

3.3.1 Decisões do Tribunal Regional Federal da $3^{\mathrm{a}}$ Região............................................ 115

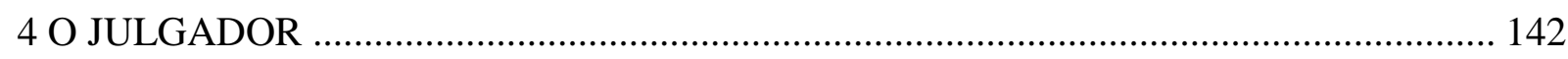

4.1 Uma educação com liberdade para alcançar a integração ........................................... 152

4.2 Conhecer o outro exige que primeiro conheça-te a ti mesmo........................................ 172

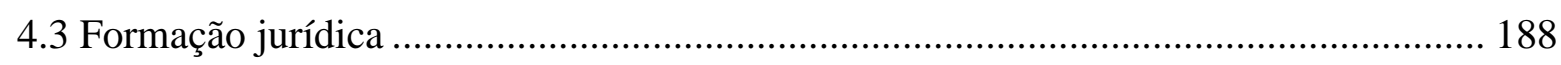

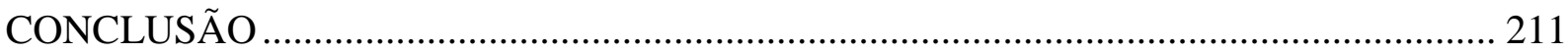

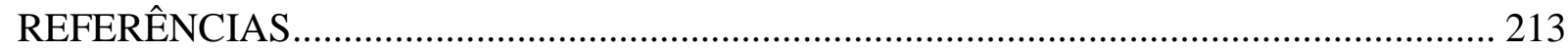




\section{INTRODUÇÃO}

A previsão da conduta social e personalidade, como circunstâncias judiciais pessoais, a serem levadas em consideração pelo julgador, para fixação da pena-base, entre o patamar mínimo e máximo, dentre outras funções, estabelecidas no artigo 59 do Código Penal, afasta o julgamento sobre o fato concreto, dirigindo-o a seu autor.

Servindo como forma de controle do Estado, não só regra o comportamento social, dirigindo modo e condução de vidas de seus agentes, como os pune, por conduzirem-se contrariamente ao esperado.

$\mathrm{Na}$ medida em que a nossa Carta Política de 1988 confere ampla liberdade de autodeterminação, de crença e de expressão, aos cidadãos brasileiros; imprimindo os valores do princípio da secularização, em que se separou o Direito da Moral; e conferindo posição de destaque ao princípio da legalidade, segundo o qual não há crime, sem lei anterior que o preveja; não há como compatibilizar a permanência dessas circunstâncias como norte para fixação da pena-base acima do mínimo legal, sem concluir por total afronta aos preceitos constitucionais.

Somente esta constatação já seria suficiente para questionar a presença dessas circunstâncias no Código Penal pátrio que não se coadunam com a Constituição Federal.

No entanto, ao verificar que a inferência em aspectos estritamente subjetivos dos agentes implica incremento do poder discricionário, quiçá arbitrário dos juízes na aplicação da reprimenda legal; uma vez que estes seres não estão acima do bem e do mal, não conseguindo se afastar, por completo, de suas próprias histórias de vida, recortes culturais e educacionais, sendo, portanto, falacioso o mito da neutralidade judicial; é que se entendeu por urgente aprofundar a reflexão sobre esse tema, que tem relevância ímpar em um Estado que se pretenda Democrático de Direito.

Esses são os temas abrangidos por este trabalho, que serão enfrentados ao longo dos três capítulos.

O primeiro capítulo trará os pontos de partida, no qual serão discutidas, ainda que brevemente, as diferenças entre o direito penal de autor e o direito penal do fato. Serão 
introduzidas as primeiras considerações sobre a irracionalidade das punições, e o quanto a aplicação das penas, ainda hoje em dia, se ressente de considerável carga emocional, e que seus julgadores, como seres humanos, não estão completamente livres de seus preconceitos, condicionamentos, crenças e etc., não havendo neutralidade nas decisões.

Nesse capítulo primeiro, serão também feitas referências ao modelo idealizado por Luigi Ferrajoli, que prega pela legalidade não só na previsão dos delitos, como na cominação e aplicação das penas. De certa forma, esse modelo é tomado como pressuposto deste trabalho, na medida em que propõe a construção de um sistema penal pautado na punição do fato, e não do autor.

No segundo capítulo, inicialmente, serão apresentadas breves observações introdutórias sobre as finalidades da pena, com destaque para o posicionamento de Luigi Ferrajoli, para quem o caráter retributivo do direito penal constitui-se na primeira garantia do cidadão de que a condição necessária da pena é, antes de mais nada, o cometimento de um delito.

Essa análise inicial será efetuada, em função de o artigo 59 do Código Penal disciplinar que o ordenamento jurídico prevê como fins da pena tanto a retribuição como a prevenção dos delitos.

Nesse mesmo capítulo, algumas notas sobre a individualização da pena serão feitas, antes de se adentrar ao conceito doutrinário atribuído à conduta social e personalidade, falando-se um pouco sobre os antecedentes, porque, ainda hoje, mesmo após a edição da Súmula 444 do STJ, aquilo que não pode ser considerado como tal tem sido indevidamente transportado para conceituar conduta social e personalidade.

O capítulo se encerra com uma compilação de diversos e variados posicionamentos de doutrinadores pátrios e alguns estrangeiros, no âmbito jurídico, do que seria conduta social e personalidade, do que pode ser englobado nessa análise, se há sustentáculo fático processual para referida análise, e por fim, se é possível aos magistrados desincumbirem-se desse encargo.

O capítulo terceiro destina-se a verificar na Jurisprudência pátria o que nossos julgadores compreendem como conduta social e personalidade, para fins de fixação da penabase. 
Dentro dessa busca, inicialmente esse capítulo trará o estudo dos precedentes que originaram a Súmula 444 do Superior Tribunal de Justiça, para observação de sua extensão.

Na sequência objetivará, por meio da análise de diversos acórdãos, checar o seu impacto no julgamento do próprio Superior Tribunal de Justiça, do Tribunal Regional Federal da $3^{\text {a }}$ Região e Tribunal de Justiça de São Paulo, verificando a resistência ou não dos desembargadores e juízes singulares em seu acatamento.

Ainda nesse capítulo serão analisados quase 500 acórdãos do Tribunal Regional Federal da $3^{\text {a }}$ Região, com o fim de verificar o que se considera como personalidade e conduta social para fins de aplicação da pena-base acima do mínimo legal.

Em função de o capítulo terceiro apontar diversidade de decisões judiciais para casos similares, em termos objetivos, o que escapa ao entendimento racional; e de desconstruir tão arraigada crença na tradicional ideia de que o juiz, ao julgar, interpreta a lei a partir de um procedimento lógico-dedutivo, no capítulo quarto, o enfoque do estudo será dado justamente à subjetividade dos julgadores.

No capítulo quarto, portanto, busca-se encontrar as razões das disparidades de decisões para casos parecidos, partindo-se, preliminarmente, do questionamento do mito da neutralidade judicial, por meio da constatação de que o exercício da jurisdição é influenciado pelo subjetivismo de seus atores, sendo que as decisões judiciais sofrem impacto de conteúdos metajurídicos, psicológicos, sendo também fruto da experiência individual do julgador e de seus preconceitos de ordem política, econômica, social.

Avançando nessa busca, a pesquisa é toda dirigida à necessidade dos julgadores tomarem conhecimento desses conteúdos internos, que permeiam suas decisões, sendo que na análise da conduta social e personalidade dos réus, a porta para a manifestação destes conteúdos inconscientes e desconhecidos está escancarada.

Para alcançar esse fim, nesse capítulo quarto faz-se uma crítica ao atual sistema Judiciário Brasileiro, que para se curar, inevitavelmente, terá como passo inicial a assunção do lado humano da Justiça, enxergando o julgador como um ser igual a todo e qualquer homem, que julga, com suas emoções e paixões. Colocando como desafio da magistratura buscar aqueles que são realmente vocacionados, que tenham interesse de conhecer a natureza vulnerável de qualquer ser humano, e de que assumindo sua fragilidade, procure se autoconhecer, para melhor servir aos jurisdicionados. 
Para se chegar a estas conclusões do capítulo quarto, a pesquisa a ser feita obedecerá a um processo de digressão em temas, que antecedem a própria escolha de ser juiz.

O primeiro item do capítulo quarto abordará a educação, desde sempre, pautada na cultura da separação, e na desconsideração das peculiaridades e belezas dos seres humanos, individualmente, considerados. Marcada pelo desrespeito com o "ser" e suas diversas manifestações, sejam elas quais forem, ainda, em infância. E na procura do referencial fora, de modo que até a escolha das profissões obedece à tônica da competição, com vistas a bons e reconhecidos empregos, ainda que sem qualquer identificação.

Nesse item, é que se pretende plantar a semente de que a educação uniforme recebida nas escolas, e a criação voltada à valorização de certos modelos em detrimento de outros, acarreta verdadeiro condicionamento do ser humano para desconsiderar as particularidades dos outros, o que implica completo contrassenso com a exigência legal de se avaliar, por conta da fixação da reprimenda legal, critérios tão subjetivos dos réus, que a vida inteira o indivíduo foi acostumado a negar.

No segundo item, partindo-se do pressuposto de que alguém que não se conhece não pode pretender conhecer o outro, serão apresentados conceitos da psicologia sobre o inconsciente, a sombra, as máscaras, falando-se da natureza dual de todos os indivíduos.

Será abordado o processo de projeção, que ocorre em todos os relacionamentos humanos, bem como serão tratados os mecanismos que os indivíduos se utilizam para afastar de si tudo aquilo que não admitem possuir, e o quanto a falta de reconhecimento desses processos acarreta verdadeiras tragédias. Aqui, será sugerido que os juízes se entreguem a um processo de autoconhecimento, que ao ver da pesquisadora, é o único meio capaz de frear as perversas projeções, na medida em que ele serve para trazer luz e chamar a atenção de que a maldade existe em todas as pessoas, não estando os magistrados ilesos. Sendo que só o reconhecimento do mal dentro de si já é portal para grandes transformações, tornando os julgadores seres mais sensíveis.

No terceiro e último item, por acreditar que o autoconhecimento não é algo que possa ser obrigado, devendo ser desejado pelo indivíduo que queira melhor conhecer-se, para melhor poder trabalhar para a sociedade; sugerem-se alterações na formação jurídica. 
Essas alterações teriam início com o questionamento do atual ensino universitário jurídico, passando pela forma como se recrutam os juízes, e na sequência o conteúdo e objetivo das escolas da magistratura.

Por fim, são expostas as conclusões do trabalho. 


\section{PRESSUPOSTOS TEÓRICOS}

\subsection{Ponto de partida}

O presente trabalho pretende estudar um tema muito problemático no direito penal. Diz respeito a uma das muitas manifestações do direito penal de autor, em que se costuma punir a pessoa mais pelo o que ela efetivamente é (o seu modo de ser) em comparação ao que ela faz (a sua conduta).

No direito penal de autor não se punem comportamentos, isto é, ações, mas sim status, padrões e/ou condições pessoais, criminalizando-se, na verdade, a interioridade do individuo ${ }^{1}$, o que tem um caráter nitidamente antidemocrático, discriminatório e seletivo, colocando em xeque a própria legitimação de todo o ius puniendi estatal.

É importante frisar que o direito penal de autor não só se manifesta por meio do direito penal, quer dizer, quando da emissão da sentença judicial, mas se concretiza ao longo de toda a persecução penal, isso desde o início do inquérito até o seu fim. E até mesmo depois do seu término, com o processo de execução penal, em caso de condenação definitiva.

Quer seja absolvido, quer seja condenado, o fato é que o sujeito sofre todo o processo como verdadeira pena, o que fica ainda mais latente nos processos penais alinhados ao sistema inquisitivo, como ocorre com o nosso Código de Processo Penal brasileiro, datado de 1941, que segue o modelo autoritário fascista italiano, há muito ultrapassado.

Evidentemente, neste trabalho não se pretendem estudar, em absoluto, todas as diversas formas de direito penal do autor (ou todas as manifestações de direito processual de autor). Quer-se circunscrever sua análise apenas no que tange, especificamente, à fixação da pena-base realizada pelo magistrado, com base nos critérios da personalidade e da conduta

\footnotetext{
1 "Não negamos que um dia, talvez, tenhamos todos (não só os criminosos) 'que responder pela personalidade total'. Mas não será, com toda certeza, perante um severo e falível juiz de carne e osso, nem segundo critérios exclusivamente jurídicos. Quando isso ocorrer estaremos provavelmente frente a um Deus-amor" (Francisco de Assis Toledo. Princípios básicos de direito penal. 5. ${ }^{a}$ ed. São Paulo: Saraiva, 1994, p. 248).
} 
social, os quais se mostram demasiadamente genéricos para permitir uma racional dosagem da pena, dando margem a modelos decisionistas, ao direito penal de autor ${ }^{2}$.

Esses critérios, dada sua vagueza e indeterminação, implicam, na verdade, uma grande margem de poder ao Estado, conferindo uma amplíssima dose de discricionariedade (ou melhor, de arbitrariedade) ao magistrado, o que não é nada desejável, sobretudo em um Estado que se pretenda Democrático de Direito.

Embora não se negue a necessidade de individualizar a pena, já que cada fato é um fato e cada pessoa é uma pessoa (afinal, "cada indivíduo é um mundo. Não existem dois delinqüentes iguais" ${ }^{3}$, de modo que as penas, por isso mesmo, devem ser dosadas de modo diferente), tem-se que o amplo recurso à análise da personalidade do sujeito pode referendar um direito penal arbitrário. Tem-se aqui um dilema entre a necessidade de bem individualizar a pena aplicada com o perigo em se permitir a punição da pessoa mais pelo que ela efetivamente é (ou aparenta sê-lo) se em comparação ao que ela efetivamente faz.

Com efeito, o dilema é que esses requisitos personalidade e conduta social admitem uma motivação muitíssimo aberta e ampla por parte do magistrado, em detrimento do modelo de legalidade estrita, ou melhor, de tipicidade fechada, que, como se terá oportunidade de destacar adiante, entende-se como o que melhor condiciona um sistema punitivo mais seguro e racional.

Tem-se que, em teoria, embora vigore um modelo de tipicidade estrita em direito penal, na prática o que se verifica é justamente o contrário, havendo ampla margem para a tomada de decisões arbitrárias e irracionais. Na verdade, as análises da personalidade e da conduta social do sujeito nada mais representam que um retorno da verificação de sua suposta

\footnotetext{
2 “Assim é que as 'circunstâncias judiciais' previstas no art. 59, do Código Penal, culpabilidade, antecedentes, conduta social, personalidade do agente, motivos e as circunstâncias e conseqüências do crime, precisam ser analisadas mais detidamente, uma vez que a 'pletora de significantes' é utilizada de maneira anti-garantista, desprezando-se o processo de secularização da sociedade contemporânea. De sorte que o julgamento, bom se lembrar, é da conduta e não da pessoa do acusado que, todavia, na fase de aplicação da pena é esquecido em nome da 'Defesa Social', pois como afirma Carvalho, em obra pioneira, "no momento da sentença penal condenatória, o sistema revela toda sua perversidade ao admitir o emprego de elementos essencialmente morais, desprovidos de significado com averiguação probatória." Neste pensar Andrade possui razão ao argumentar que tudo já se encontra em frases feitas repassadas nos 'cursinhos para concurso', depois utilizadas na prática forense, sem qualquer reflexão crítica, tornando as decisões absolutamente nulas num 'Estado Democrático de Direito'”. (Alexandre Morais da Rosa. Decisão no Processo Penal como Bricolage de Significantes. Tese de Doutoramento apresentada na Universidade Federal do Paraná, em 2004, p. 49). (destaques do autor).

${ }^{3}$ Fernando Falcón y Tella e Maria José Falcón y Tella. Fundamento e finalidade da sanção: existe um direito de castigar? Tradução de Claudia de Miranda Avena. São Paulo: RT, 2008, p. 219.
} 
periculosidade, tal qual sempre se fez nos regimes totalitários, o que é inadmissível, sobretudo se quisermos instituir um direito penal que esteja circunscrito à análise do fato.

Aliás, a história das penas bem demonstra o quanto o sistema penal tem se mostrado irracional e até mesmo mais vergonhosa que a da violência da prática dos próprios crimes.

A aplicação da pena ostenta em si uma carga emocional que não pode ser olvidada, já que o crime, mais que qualquer outro fenômeno social, choca a todos (inclusive ao magistrado) e causa certo clamor social: ainda que a aplicação da pena tenha sido retirada da esfera dos diretamente envolvidos para se tornar produto do monopólio estatal (retirando-se da vítima o amplo poder vingativo), essa carga emocional ainda se encontra presente nos dias de hoje (direito penal do inimigo), o que, em certa medida, explica a razão de sempre ter havido a aplicação de penas desproporcionais.

Por isso, bem afirma Anabela Miranda Rodrigues que "quaisquer que sejam os vínculos legalmente impostos à discricionariedade do juiz, a irracionalidade é, no entanto, um factor ineliminável do processso de determinação da medida da pena"4

Em síntese, o ato de punir sempre ostentou uma marca de irracionalidade e crueldade ínsita, cumprindo ao sistema jurídico instituir freios e balizas ao arbítrio desmedido.

Este estudo é importante, pois o direito penal de autor sempre esteve presente em qualquer Estado ou regime político. Não se trata de um privilégio deste ou daquele tipo ou modelo de Estado: um direito penal arbitrário esteve presente tanto nos Estados democráticos quanto nos mais autoritários; tanto nos regimes de direita quanto nos regimes de esquerda.

Hoje, de certa forma, existe um novo direito penal de autor, consubstanciado no direito penal do risco, que, como alertam, entre outros, Eugênio Raúl Zaffaroni e Nilo Batista, “antecipa a tipicidade na direção de atos de tentativa e mesmo preparatórios, o que aumenta a relevância dos elementos subjetivos e normativos dos tipos penais, pretendendo assim controlar não apenas a conduta, mas também a lealdade do sujeito ao ordenamento [...] Esta

\footnotetext{
${ }^{4}$ Anabela Miranda Rodrigues. A determinação da medida da pena privativa de liberdade. Coimbra: Coimbra, 1995, p. 88.
} 
orientação culmina com o retorno à presunção do dolo, através da chamada normatização, que prescinde da vontade real",

Não há como negar o fato histórico de que o direito penal sempre esteve mais voltado para incidir sobre determinados tipos de pessoas em comparação a outras. E essa (maior) incidência também se dá no momento de dosar a pena, já que aos sujeitos reputados mais indesejáveis sempre foram aplicadas penas mais rigorosas.

Pode-se afirmar, com Luigi Ferrajoli, que a história das punições foi, de fato, mais vergonhosa que toda a história dos próprios delitos ${ }^{6}$. A punição e a ojeriza ao delinqüente e aos delitos perpetrados, muitas vezes, guardam algo de irracional e inconsciente (já se teorizou que a punição deveria se dar de acordo com a beleza ou feiura ${ }^{7}$ ), e inclusive, até por razões mesmo inconfessáveis, também ostentam em si um misto de excitação e prazer por parte dos demais membros da comunidade que assistem ao horror do espetáculo punitivo.

Sempre foi assim, seja nos julgamentos mais antigos da história, como ocorria em Roma (ritual da crucificação, em que Jesus Cristo foi exposto como um animal ao povo), seja nos julgamentos eclesiásticos dos hereges e bruxas (chicotadas, fogueiras, etc.) ou mesmo no período das Luzes (terror da guilhotina da Revolução Francesa). Hoje, o que se tem é um espetáculo um tanto quanto diferenciado, cuja violência é mais amena e sutil se comparada às épocas mais remotas da história, mas que ainda assim existe, podendo-se citar os julgamentos sumários com a ampla exposição midiática.

O fato é que há um “complexo amálgama de sensações e paixões mais que uma paixão coletiva uniforme" que rondam o crime, aglutinando sentimentos muitas vezes absolutamente contraditórios como os de simpatia, piedade, amor, benevolência, perdão, como bem ensinam e, a esse respeito, ponderam Fernando Falcón y Tella e María José Falcón y Tella ${ }^{9}$ e,

\footnotetext{
${ }^{5}$ Alejandro Alagia et al. Direito Penal Brasileiro: teoria geral do direito penal. Rio de Janeiro: Revan, 2003, p. 133.

${ }^{6}$ Luigi Ferrajoli. Direito e razão: teoria do garantismo penal. Tradução de Ana Paula Zomer et al. São Paulo: RT, 2002, p. 310.

${ }^{7}$ Como aponta Sérgio Salomão Shecaira, os fisionomistas relacionavam os aspectos físicos ao aspecto moral da pessoa, de modo que para alguns estudiosos "tanto a beleza quanto a feiúra eram reflexos da bondade ou da maldade da pessoa" (Sérgio Salomão Shecaira. Criminologia. São Paulo: RT, 2004, p. 78).

${ }^{8}$ Fernando Falcón y Tella e Maria José Falcón y Tella. Fundamento e finalidade da sanção: existe um direito de castigar? Tradução de Claudia de Miranda Avena. São Paulo: RT, 2008, p. 66.

${ }^{9}$ Fernando Falcón y Tella e Maria José Falcón y Tella. Fundamento e finalidade da sanção: existe um direito de castigar? Tradução de Claudia de Miranda Avena. São Paulo: RT, 2008, p. 66.
} 
acrescentamos nós, até mesmo de certo heroísmo, o que, comumente, vem atrelado a algumas práticas terroristas, legitimadas por ideologias e pelo meio social.

Portanto, correto afirmar, que na hora de castigar, há um misto de sensações, emoções e impulsos, que não podem ser diferenciadas.

A excitação que a punição acarreta na generalidade das pessoas indica certo tipo de "prazer secreto", um gozo, o que tem algo de irracional e se encontra presente na sociedade como um todo, inclusive nos magistrados. Ao castigar os que praticaram o crime (os que não controlaram seus impulsos), aqueles que não delinquem, além de ver na punição do outro um acalento ao seu próprio sadismo, introjetam que é mesmo importante manter controladas as suas próprias pulsões.

A psicologia bem explica a razão de assim acontecer, ao tratar dos processos de projeções, que ocorrem com todos os mortais.

No presente trabalho, tendo em vista que o objetivo é o questionamento das circunstâncias personalidade e conduta social, como balizadoras da fixação da pena-base entre o mínimo e máximo, e como tal aferição é feita pelos juízes criminais, muito se falará desses seres que escolheram como profissão de vida julgar seus semelhantes. E nesta toada, na medida em que os condicionamentos, emoções e impulsos descritos acima pertencem a todos os humanos, não há possibilidade de afastar, ou melhor, de isentar os magistrados de serem afetados pelos mesmos sentimentos.

Nesse sentido, percucientes as palavras de Miguel Reale, ao dispor que:

Note-se que ninguém se liberta de sua condicionalidade existencial, porquanto quem se distingue, por virtudes de excelência, não pode pretender ser superior à sociedade, pois, no momento em que ele se ergue, eleva consigo a sociedade a que pertence. Esse sentido comunitário de vida veio alterar a perspectiva das ciências humanas, do Direito inclusive. Estamos, vendo, portanto, por estas considerações prévias, que a ética do juiz não pode ser reduzida a um catecismo de deveres abstratos, pressupondo, ao contrário, a vivência do Direito em sua circunstancialidade cultural. É óbvio que ele, antes de ser juiz, é homem, mas é esta nota "humana" comum que é freqüentemente esquecida, como se se tratasse de mero enunciador de juízos e sentenças, uma espécie de "robô" a elaborar silogismos com força obrigatória. ${ }^{10}$

\footnotetext{
${ }^{10}$ Miguel Reale. A Ética do Juiz na Cultura Contemporânea. In: José Renato Nalini (Coord.). Uma Nova Ética para o Juiz. São Paulo: RT, 1994, p. 138-139.
} 
A esse respeito, pondera-se que no Capítulo $4^{\circ}$, que tratará do Julgador, sob a perspectiva de sua interioridade, esta questão será retomada e aprofundada.

\subsection{A nova concepção de delito: do delito pecado para o delito fato e o primeiro passo para uma maior racionalização do poder de punir}

Sabe-se, na época mais recente, que não há um conceito naturalístico de crime.

O crime é, nesse aspecto, uma convenção, uma construção social, haja vista que nos mais diversos períodos históricos, ora se consideraram criminosos determinados fatos, ora não. A homossexualidade é um exemplo paradigmático, pois foi prática ora aceita, ora incentivada, ora tolerada e ora criminalizada em diversas épocas históricas, sendo, nos dias de hoje, aceita em alguns ordenamentos e criminalizada em tantos outros.

Haja vista não haver mais um conceito ontológico de crime, mas meramente axiológico, ou melhor, normativo, a prática do crime não indica por si só que o seu autor (criminoso) seja uma pessoa má. Com efeito, há pessoas más que não cometem crimes e pessoas boas que, pelas mais diversas razões da vida, são levadas a cometê-lo.

O delito perdeu a sua identificação com o pecado, o que também contribui para conferir maior racionalidade na sua punição. "Na realidade, todos somos bons e maus ao mesmo tempo, dependendo do momento. A arte, a literatura e o cinema contemporâneos se esforçam para demonstrar a complexidade do real e a irrealidade dos discursos em branco e preto", 1 .

Aliás, hoje já é conhecimento comum que uma sociedade sem crime é não só utópica, sendo o crime um fenômeno considerado absolutamente normal em qualquer sociedade, desde que, evidentemente, não quebre o equilíbrio social, colocando em risco o próprio arranjo social. Nas palavras de Miguel Reale Júnior, "nem sempre são o delito e o desvio efetivamente nocivos, pois, por vezes, historicamente, mostraram-se atos de transformação social, revelações de novas formas de pensar e sentir, rejeitadas e reprimidas pela sociedade

\footnotetext{
${ }^{11}$ Fernando Falcón y Tella e Maria José Falcón y Tella. Fundamento e finalidade da sanção: existe um direito de castigar? Tradução de Claudia de Miranda Avena. São Paulo: RT, 2008, p. 132.
} 
estabelecida, como a liberdade de manifestação de pensamento, e se não fosse o desrespeito às regras impeditivas, jamais teriam sido consagradas" $" 12$.

Tendo em vista o exposto, dado a mudança de concepção do significado do crime, acerta Francisco de Assis Toledo quando afirma que o direito penal "não pode, pois, ter pretensões de modelar, sob cominação de pena, o 'ser existencial' do homem. Essa missão não lhe compete. Corretíssimos os autores do Projeto Alternativo da Alemanha Federal, quando fizeram inserir em sua motivação esta expressão lapidar: 'Pena a ser aplicada não constitui um fenômeno metafísico' ('Strafe zu verhangen ist Jein metaphysicher Vorgang...')”,13.

Não sendo o crime um pecado, não há razão para se pretender punir a alma. Quando muito, se pode censurar o fato cometido, nunca a pessoa que é sua autora, o que tem relevância na hora de se examinar a aplicação, não sendo mais lícito que, em um Estado que se pretenda Democrático de Direito, os magistrados, quão semideuses na Terra, julguem a alma do criminoso (ou melhor, a sua personalidade).

\subsection{O modelo de Luigi Ferrajoli: legalidade não só na previsão dos delitos, mas também na cominação e aplicação das penas}

Luigi Ferrajoli formulou um modelo de legalidade e jurisdicionariedade estritas ideais. Embora esse modelo nunca seja realizável plenamente - conforme o próprio autor expõe ${ }^{14}$ até por conta da debilidade intrínseca a toda e qualquer forma de conhecimento, em que, fatalmente, sempre há alguma dose de discricionariedade, é um norte a ser seguido, em prol da liberdade e segurança de todos. O autor italiano pretendeu (e o fez, de modo efetivo) construir um sistema penal pautado na punição do fato, e não do autor, premissa com a qual se alinha este trabalho. Portanto, tratar um pouco da obra de Luigi Ferrajoli, nesta oportunidade, se

\footnotetext{
${ }^{12}$ Miguel Reale Júnior. Instituições de direito penal: parte geral. 3. a ed. Rio de Janeiro: Forense, 2009, p. 09.

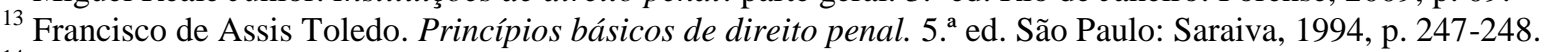

14 "Todo esquema epistemológico até aqui ilustrado e o modelo garantista que nele se informa tem o defeito fundamental de corresponder a um modelo limite, amplamente idealista, porque de fato nunca foi realizado nem nunca será realizável" (Luigi Ferrajoli. Direito e razão: teoria do garantismo penal. Tradução de Ana Paula Zomer et al. São Paulo: RT, 2002, p. 33).
} 
mostra imperioso, pois é a partir da sua teoria do garantismo penal que muitas das conclusões deste trabalho estarão alicerçadas.

Como expõe o autor em referência, o princípio da legalidade estrita é o único que pode vincular até mesmo o próprio legislador, na medida em que é "dirigida a excluir, conquanto arbitrárias e discriminatórias, as convenções penais referidas não a fatos, mas diretamente a pessoas e, portanto, como caráter 'constitutivo' e não 'regulamentar' daquilo que é punível: como normas que, em terríveis ordenamentos passados, perseguiam bruxas, os hereges, os judeus, os subversivos e os inimigos do povo; como as que ainda existem em nosso ordenamento, que perseguem os 'desocupados' e os 'vagabundos', os 'propensos a delinquir' os 'dedicados a tráficos ilícitos', os ‘socialmente perigosos' e outros semelhantes”.15.

A legalidade estrita constituiria o traço distintivo e peculiar à jurisdição penal, na medida em que "seus pronunciamentos, diferentemente do que ocorre em qualquer outra atividade pública, a lei pretende predeterminar não apenas as formas, mas também os conteúdos" "16. Como bem consigna Luigi Ferrajoli: "a lei não pode qualificar como penalmente relevante qualquer hipótese indeterminada de desvio, mas somente comportamentos empíricos determinados, identificados exatamente como tais e, por sua vez, aditados à culpabilidade de um sujeito" ${ }^{17}$, daí residindo a diferenciação entre $\underline{\text { mera }}$ legalidade e legalidade estrita.

O modelo pautado no cognitivismo judicial, conforme denomina o próprio Luigi Ferrajoli, privilegia o valor igualdade, na medida em que se punem apenas condutas (mediante ações determinadas, taxativas e certas) que sejam comuns a todos os indivíduos e, portanto, não, propriamente, especiais modos de ser de cada um. ${ }^{18}$

Somente por convencionalismo jurídico (convenção) e não por qualquer tipo de imoralidade ou anormalidade se pode considerar um fato como delituoso.

\footnotetext{
${ }^{15}$ Luigi Ferrajoli. Direito e razão: teoria do garantismo penal. Tradução de Ana Paula Zomer et al. São Paulo: RT, 2002, p. 31.

${ }^{16}$ Luigi Ferrajoli. Direito e razão: teoria do garantismo penal. Tradução de Ana Paula Zomer et al. São Paulo: RT, 2002 , p. 37.

${ }^{17}$ Luigi Ferrajoli. Direito e razão: teoria do garantismo penal. Tradução de Ana Paula Zomer et al. São Paulo: RT, 2002, p. 31.

18 "as ações ou fatos, por quem quer que os tenha cometido, podem ser realmente descritos pelas normas como 'tipos objetivos' de desvio e, enquanto tais, ser previstos e provados como pressupostos de igual tratamento penal; enquanto toda pré-configuração normativa de 'tipos subjetivos' de desvio não pode deixar de referir-se a diferenças pessoais, antropológicas, políticas ou sociais e, portanto, de exaurir-se em discriminações apriorísticas". (Luigi Ferrajoli. Direito e razão: teoria do garantismo penal. Tradução de Ana Paula Zomer et al. São Paulo: RT, 2002, p. 31).
} 
Só assim é possível discorrer, com certa dose de segurança e razoabilidade, se a afirmação feita com relação à ocorrência do delito é, ou não, verdadeira. Apenas com respeito a fatos (e não ao caráter ou a qualquer outra condição) se pode fazer algum juízo idôneo de verificação mediante provas racionalmente produzidas acerca da veracidade da imputação feita (e não com base em termos vagos e valorativos). ${ }^{19}$

Para Luigi Ferrajoli:

comportamentos como ato obsceno ou o desacato, por exemplo, correspondem a figuras delituosas, por assim dizer, 'em branco', cuja identificação judicial, devido à indeterminação de suas definições legais, remete inevitavelmente, muito mais do que a provas, a discricionárias valorações do juiz, que de fato esvaziam tanto o princípio formalista da legalidade quanto o empírico da fatualidade do desvio punível. Para que estes mesmos princípios sejam satisfeitos é necessário, além disso, que não só a lei, senão também o juízo penal, careçam de caráter 'constitutivo' e tenham caráter 'recognitivo' das normas e 'cognitivo' dos fatos por elas regulados ${ }^{20}$.

Um modelo de legalidade estrita não se restringe a fatos, abarcando igualmente as questões de direito. Assim, a legalidade estrita não apenas pressupõe a descrição, no tipo penal, de um fato certo, determinado e, por isso, verificável, mas também um direito que não seja muito vago e incerto, que não dê margem a amplas interpretações, mediante os quais poderia haver uma indevida ampliação da criminalização.

Sua atividade deve ser essencialmente recognitiva (do direito) e não criativa do direito. Dessa forma, também todas as questões de direito (classificação do delito) têm que ser suficientemente claras.

19 'Em que condições podemos usar sensatamente os termos 'verdadeiro' e 'falso' como predicados de
afirmações do tipo 'Tício cometeu o fato F' e 'o fato F cometido por Tício configura o delito G'? Em termos
gerais, numa concepção empirista do conhecimento são verificáveis e falseáveis no sentido de 'verdade', como
elucidado no parágrafo 3, apenas as afirmações dotadas de significado ou de referência empírica, quer dizer, que
descrevem fatos ou situações determinadas a partir do ponto de vista da observação: por exemplo, 'a terra é um
planeta que gira em torno do sol' ou 'Caio violou o limite de velocidade de 50 Km por hora ao dirigir no centro
de Roma a 60 Km por hora', ou similares. Não o são, ao contrário, os juízos de valor e as afirmações de fatos ou
situações a partir do ponto de vista da observação: por exemplo. 'Caio ofendeu a moral', 'Semprônio cometeu
atividades subversivas', 'Mévio é socialmente perigoso' ou 'a terra e o sol foram criados por Deus e se movem
segundo as regras por Ele estabelecidas'. As condições de verificabilidade e da falseabilidade, quer dizer, do uso
dos termos 'verdadeiro' e 'falso', a propósito de uma afirmação, dependem assim da semântica da linguagem na
qual seja formulada, quer dizer, do fato de que sabemos exatamente a que nos referimos com as palavras que nela
utilizamos" (Luigi Ferrajoli. Direito e razão: teoria do garantismo penal. Tradução de Ana Paula Zomer et al. São
Paulo: RT, 2002, p. 96). ${ }^{20}$ Luigi Ferrajoli. Direito e razão: teoria do garantismo penal. Tradução de Ana Paula Zomer et al. São Paulo: RT, 2002, p. 32. 
É evidente que, para a validez de semelhante silogismo, é necessário, em primeiro lugar, que o conceito classificatório seja suficientemente preciso, como para permitir demarcações exclusivas e exaustivas a respeito das permitidas por outros conceitos ditados por normas concorrentes e, inclusive, a respeito da categoria dos fatos penalmente irrelevantes. Esta precisão - como, ademais, ocorre em muitos conceitos classificatórios das ciências naturais - é quase sempre, segundo se sabe, insuficiente. Tome-se o caso já exemplificado das 'lesões graves', que corresponde a uma das figuras de delito definidas na lei de maneira mais precisa. Na presença de que condições se pode afirmar que a vida de uma pessoa é posta em perigo? Que significam 'ocupações habituais' e 'incapacidade' para atendê-las? Quando se pode falar de 'debilidade permanente de um sentido ou de um órgão'? É apenas o caso de sublinhar que cada uma destas expressões admite uma pluralidade de interpretações distintas, todas elas opinativas e que o juiz tem o poder de escolher a que considere mais apropriada mediante uma decisão discricionária que pode ser mais ou menos arbitrária e racional ${ }^{21}$.

E essa indeterminação acaba vulnerando todas as demais garantias instituídas em prol de um modelo racional de direito penal.

Tipos penais valorativos propiciam um direito penal fundado apenas no perigo (abstrato), em que não há, claramente, a visualização de uma lesão ao bem jurídico.

Sistemas orientados no direito penal de autor, como esclarece Luigi Ferrajoli, que são os sistemas ou normas “sem ação", reprimem, além de determinados comportamentos, atitudes ou situações subjetivas de imoralidade, de perigosidade ou de hostilidade ao ordenamento, independentemente de sua exteriorização em manifestações delituosas concretas. Tais "sistemas prescindem da lesão de bens jurídicos concretos, ou reprimindo antecipadamente a simples e freqüente colocação abstrata em perigo, ou mesmo punindo puramente o desvalor social ou político da ação, para além de qualquer função penal de tutela",22.

E o modelo de legalidade estrita pressupõe um sistema judicial que possa, da mesma forma, apurar adequadamente as imputações, pois constitui um abuso contra o direito de defesa haver acusações pautadas apenas em juízos de valor, acusações abertas, imprecisas, como, por exemplo, pela prática de ato obsceno, de maus tratos, etc. Um sistema está conectado ao outro. A vulneração de um implica (penal e processual) a do outro. O direito é um todo incindível. Não pode ser analisado em compartimentos estanques.

\footnotetext{
${ }^{21}$ Luigi Ferrajoli. Direito e razão: teoria do garantismo penal. Tradução de Ana Paula Zomer et al. São Paulo: RT, 2002, p. 45.

${ }^{22}$ Luigi Ferrajoli. Direito e razão: teoria do garantismo penal. Tradução de Ana Paula Zomer et al. São Paulo: RT, 2002, p. 80.
} 
O sistema idealizado por Luigi Ferrajoli pretende afastar, ao máximo possível, modelos pautados no decisionismo e no subjetivismo inquisitivo, que seriam próprios da epistemologia inquisitiva, e, portanto, antigarantista, fundada em uma análise ontológica ou substancialista do delito, considerado por si só imoral ou antissocial ${ }^{23}$.

\begin{abstract}
O primeiro aspecto da epistemologia antigarantista é a concepção não formalista nem convencional, mas sim ontológica ou substancialista do desvio penalmente relevante. Segundo esta concepção, objeto de conhecimento e tratamento penal não é apenas o delito enquanto formalmente previsto em lei, mas o desvio criminal enquanto em si mesmo imoral ou anti-social e, para além dele, a pessoa do delinqüente, de cuja maldade ou anti-sociabilidade o delito é visto como uma manifestação contingente, suficiente, mas nem sempre necessária para justificar a punição. Esta idéia, como veremos no parágrafo 27 , tem tido muitas e diversas versões: das doutrinas moralistas, que consideram o delito um pecado, às naturalistas, que individualizam nele um signo de anormalidade ou de patologia psicofísica do sujeito, até as pragmáticas e utilitaristas, que lhe conferem relevância somente enquanto sintoma privilegiado e alarmante da periculosidade de seu autor. No plano das técnicas jurídicas, estas representações se refletem em uma desvalorização do papel da lei como critério exclusivo e exaustivo de definição dos fatos desviados. A técnica mais difundida é a previsão de figuras de delito elásticas e indeterminadas, idôneas para conotar, em termos vagos ou valorativos, modelos globais de desvio - como a obscenidade, o desacato, a propaganda ou a associação subversiva, a associação de tipo mafioso, a ofensa à moral familiar e similares - em vez de indicar univocamente tipos de delito empiricamente determináveis ${ }^{24}$.
\end{abstract}

Como visto acima, há as doutrinas moralistas, sendo o delito interpretado e confundido com o pecado, sem falar as correntes naturalistas, que vislumbram no crime um sinal de anormalidade ou de patologia daquele que vem a delinquir. Luigi Ferrajoli também aponta as correntes pragmáticas, ou utilitaristas, "que lhe conferem relevância somente enquanto sintoma privilegiado e alarmante da periculosidade de seu autor, ${ }^{, 25}$.

Para o garantismo, mormente no sistema proposto pelo referido autor, a verdade é algo do que não se pode prescindir; mesmo porque, esse seria o único valor que fundamenta e

\footnotetext{
${ }^{23}$ Luigi Ferrajoli. Direito e razão: teoria do garantismo penal. Tradução de Ana Paula Zomer et al. São Paulo: RT, 2002, p. 35.

${ }^{24}$ Luigi Ferrajoli. Direito e razão: teoria do garantismo penal. Tradução de Ana Paula Zomer et al. São Paulo: RT, 2002, pp. 35-36.

${ }^{25}$ Luigi Ferrajoli. Direito e razão: teoria do garantismo penal. Tradução de Ana Paula Zomer et al. São Paulo: RT, 2002, p. 35.
} 
legitima todo o sistema penal garantista (devendo se afastar de outros tipos de legitimação), pois só a busca da verdade pode conformar o modelo penal do fato ${ }^{26}$.

Com efeito, somente o apreço à concepção de verdade pode afastar valorações subjetivas a respeito se o sujeito é ou não perigoso, se é ou não propenso à prática de crimes, isso tanto em âmbito legislativo como judicial.

Assim ocorre porque a concepção de verdade legitima e fundamenta o direito penal do fato, pois só pode ser analisado de acordo esse valor ações determinadas (se A praticou determinado fato) e não estados de ânimo (se A é perigoso, é vadio, etc., pois isso não tem como ser verificado). Os estados de ânimos, assim como o tipo da personalidade, nunca podem ser verificados, mas apenas são dados argumentáveis, com base em juízos de valor.

O ponto da questão é como se interpreta essa verdade e qual a forma de atingi-la. Cumpre aqui fazer um paralelo entre a verdade perseguida no modelo de direito alinhado à vertente do direito penal de autor e o alinhado a um direito penal mais garantista.

O sistema penal autoritário (direito penal de autor) visa a atingir uma verdade total, absoluta. Nesse tipo de sistema, poder-se-ia almejar o conhecimento absoluto e holístico não só do crime, mas também de seu agente. Em ditos sistemas, pretende-se julgar não só o fato, e suas circunstâncias, mas também a pessoa que o pratica. ${ }^{27}$

Diferentemente ocorre em sistemas mais garantistas, pautados na busca de uma verdade atingível, que só pode se circunscrever ao fato.

Assim, no direito penal liberal, que funda um sistema de legalidade estrita, não se busca uma verdade substancial, quer dizer "uma verdade absoluta e onicompreensiva em

\footnotetext{
26 "No direito penal, a única justificação aceitável das decisões é representada pela verdade de seus pressupostos jurídicos e fáticos, entendida a 'verdade' precisamente no sentido da 'correspondência' mais aproximada possível da motivação às normas aplicadas e aos fatos julgados." (Luigi Ferrajoli. Direito e razão: teoria do garantismo penal. Tradução de Ana Paula Zomer et al. São Paulo: RT, 2002, p. 56).

27 'É evidente que esta pretendida 'verdade substancial', ao ser perseguida fora de regras e controles e, sobretudo, de uma exata predeterminação empírica das hipóteses de indagação, degenera em juízo de valor, amplamente arbitrário, assim como o cognitivismo ético sobre o qual se baseia o substancialismo penal resulta inevitavelmente solidário com uma concepção autoritária e irracionalista do processo penal" ${ }^{27}$ (Luigi Ferrajoli. Direito e razão: teoria do garantismo penal. Tradução de Ana Paula Zomer et al. São Paulo: RT, 2002, p. 38).
} 
relação às pessoas investigadas, carente de limites e de confins legais, alcançável por qualquer meio, para além das rígidas regras procedimentais" 28 .

A verdade que se busca é sempre uma verdade formal, aproximativa em relação ao fato naturalístico, alcançada pelo respeito às regras, com relação somente a fatos e circunstâncias penalmente relevantes, sendo uma verdade mais controlada.

Mesmo porque a verdade absoluta é sempre utópica, inalcançável ${ }^{29}$, já que o juiz não é (nem nunca será) um ser neutro. Ele até muito bem pode (e tem que ser) imparcial, porém, dificilmente, será alguém absolutamente neutro ${ }^{30}$.

Como fala Luigi Ferrajoli: "por mais que se esforce para ser objetivo, está sempre condicionado pelas circunstâncias ambientais nas quais atua, pelos seus sentimentos, suas inclinações, suas emoções, seus valores ético-políticos. A imagem proposta por Beccaria do

${ }^{28}$ Luigi Ferrajoli. Direito e razão: teoria do garantismo penal. Tradução de Ana Paula Zomer et al. São Paulo: RT, 2002, p. 38.

29 "A impossibilidade de formular um critério seguro de verdade das teses judiciais depende do fato de que a verdade 'certa', 'objetiva' ou 'absoluta' representa sempre a 'expressão de um ideal' inalcançável" (Luigi Ferrajoli. Direito e razão: teoria do garantismo penal. Tradução de Ana Paula Zomer et al. São Paulo: RT, 2002, p. 42).

30 "Resulta, assim, completamente fundada a crítica à idéia de uma perfeita neutralidade do juiz e do jurista, formulada anos passados, sobretudo na Itália, pelos setores progressistas da cultura jurídica. Ainda que um sistema penal adira normativamente ao modelo cognitivo e garantista - e veremos quanto não o é o italiano -, jamais será de fato um sistema fechado e exigirá sempre, para seu funcionamento prático, heterointegrações remetidas à autonomia e discricionariedade, o juiz em particular jamais será neutro, se não se entender por 'neutralidade' apenas sua honestidade intelectual e seu desinteresse pessoal em relação aos interesses concretos da causa, mas uma impossível ausência de valorações ou uma apoliticidade das opções e uma ilusória objetividade dos juízos de valor. Se as escolhas são inevitáveis, e tanto mais discricionárias quanto mais amplo seja o poder judicial de disposição, será, quando menos, condição de seu controle e autocontrole, se não cognitivo, pelo menos político e moral, que aquelas sejam conscientes, explícitas e informadas em princípios, antes que acríticas, mascaradas ou, em todo caso, arbitrárias. $\mathrm{O}$ reconhecimento dos espaços existentes de poder dispositivo e discricionário que viciam a função judicial, o ônus de argumentar seus modos de exercício mediante princípios e sua exposição a controle público, assim, não só não contradizem o modelo de direito penal mínimo, mas constituem parte integrante dele. A repulsa do caráter político do juízo é, com efeito, fruto de um equívoco: confunde os espaços estruturais de arbítrio, deixados em aberto no ordenamento pela carência de garantias, com o débil remédio oposto diante deles. Na realidade, o que é ilegítimo, pois altera a jurisdição em sentido políticoadministrativo, é o poder de disposição, gerado pela colocação substancialista e decisionista do sistema e não, sem dúvida, os argumentos políticos ou substancialistas com os quais é exercido e controlado. Sob este aspecto, ainda perseguindo a fundamentação do poder judicial com bases o mais cognitivistas possível e sua redução aos estritos poderes de verificação e de conotação, o garantismo não tem nada a ver com o legalismo e o liberalismo. Pelo contrário, inclui a crítica à ideologia mecanicista da aplicação da lei. Com efeito, porque em nenhum sistema o juiz é uma máquina automática, concebê-lo como tal significa fazer dele uma máquina cega, presa da estupidez ou, pior, dos interesses e dos condicionamentos de poder mais ou menos ocultos e, em todo caso, favorecer sua irresponsabilidade política e moral." (Luigi Ferrajoli. Direito e razão: teoria do garantismo penal. Tradução de Ana Paula Zomer et al. São Paulo: RT, 2002, p. 139-140). 
juiz como 'investigador imparcial do verdadeiro' é, sob este aspecto, fundamentalmente ingênua" 31 .

\begin{abstract}
Mais além das alterações desonestas e partidárias do verdadeiro, na realidade são possíveis e em certa medida inevitáveis as deformações involuntárias, devidas ao fato de que toda reconstrução judicial minimamente complexa dos fatos passados equivale, em todo caso, à sua interpretação, que é obtida pelo juiz a partir de hipóteses de trabalho, que, ainda quando precisadas ou modificadas no curso da investigação, o levam a valorizar algumas provas e a descuidar-se de outras, e o impedem, às vezes, não apenas de compreender, mas inclusive de ver dados disponíveis em contraste com elas. Em todo juízo, em suma, sempre está presente uma certa dose de preconceito. ${ }^{32}$
\end{abstract}

É verdade que a investigação judicial se assemelha, de fato, a uma investigação histórica, mas há fatores que dificultam uma investigação isenta, como ocorre na investigação científica e histórica (que, ainda assim, não está totalmente despida de condicionamentos), principalmente, em se tratando de uma apuração levada a cabo na Justiça. ${ }^{33}$

E toda essa subjetividade é ainda mais agravada pela subjetividade das fontes de provas, que acabam influindo na apuração dos fatos.

Apesar disso, o autor afirma que não se deve ter uma postura cética radical com relação à verdade, pois esse ceticismo só contribui para tomadas de decisões irracionais.

Quando se perde qualquer esperança de chegar a uma conclusão razoável acerca da investigação judicial (a quem Luigi Ferrajoli chama de iluministas desiludidos), contribui-se para construir sistemas apartados de toda e qualquer verdade, o que é perigoso.

\footnotetext{
${ }^{31}$ Luigi Ferrajoli. Direito e razão: teoria do garantismo penal. Tradução de Ana Paula Zomer et al. São Paulo: RT, 2002, p. 46.

${ }^{32}$ Luigi Ferrajoli. Direito e razão: teoria do garantismo penal. Tradução de Ana Paula Zomer et al. São Paulo: RT, 2002 , p. 47.

33 "O objeto da investigação judicial costuma afetar mais no plano da moral e emocional do que os da investigação histórica ou científica, ainda que não de modo maior porque o conhecimento judicial deve chegar necessariamente a uma decisão prática. Isto intensifica o distanciamento do juiz para com os eventos que tem a tarefa de comprovar, e torna mais árdua sua serenidade de decisão, a qual resulta mais diretamente influenciada por suas convicções morais e políticas pessoais e pelos condicionamentos culturais e sociais exercidos sobre ele pelo ambiente externo" (Luigi Ferrajoli. Direito e razão: teoria do garantismo penal. Tradução de Ana Paula Zomer et al. São Paulo: RT, 2002, p. 47).
} 
A rigor, se se pensasse que o juízo penal devesse alcançar a verdade 'objetiva' e se tomasse ao pé da letra o princípio in dubio pro reo, as margens irredutíveis de incerteza, que caracterizam a verdade processual, deveriam comportar a ilegitimidade de qualquer condenação e, portanto, a paralisia da função judicial. Ou, ao contrário, poderiam gerar um resignado cepticismo judicial, disposto a afastar como ilusória qualquer pretensão de perseguir a verdade no processo e a avalizar modelos de direito e de processo penal abertamente substancialistas e decisionistas. Estas duas opções são inaceitáveis [...]. Também os decisionistas em matéria processual são mui frequentemente iluministas desiludidos. O fato de a investigação judicial não estar condicionada a alcançar a verdade objetiva, de estar condicionada pela subjetividade e até pela neutralidade do juiz, enfim, de haver lugar ali para momentos de decisão - todos elementos comuns, quando que em distinta medida, à investigação científica - pode na realidade conduzir a soluções decisionistas, sobretudo a quem não consiga conceber a busca da verdade no processo, senão segundo o velho espelho iluminista da aplicação mecânica da lei ao fato infalivelmente comprovado. O resultado do irracionalismo no direito, contudo, é incomparavelmente mais grave. Com efeito, se o mundo segue em frente e as ciências naturais progridem no aumento de seu conhecimento, a despeito dos irracionalistas desiludidos, no direito tanto a ciência quanto seu objeto são um produto dos homens e dependem do quanto eles, por interesse e cultura, pensam e querem em torno do direito. Por isso, uma opção teórica do tipo decisionista, pouco importa se devida à desconfiança céptica ou a convencida adesão política, favorece de fato a fundação de sistemas jurídicos com legalidade atenuada e modelos de intervenção penal do tipo potestativo e antigarantista. Enquanto isso, o reconhecimento da insuprimível, mas sempre relativa e redutível, certeza da verdade processual é o pressuposto necessário para nele se embasarem, no plano teórico e prático, critérios mais racionais de comprovação e de controle, além de certos hábitos de investigação mais rigorosos, e uma maior prudência no juízo ${ }^{34}$.

\section{Só assim se consegue um sistema penal mais racional.}

\section{Como discorre Luigi Ferrajoli:}

Um direito penal é racional e correto à medida que suas intervenções são previsíveis e são previsíveis; apenas aquelas motivadas por argumentos cognitivos de que resultem como determinável a 'verdade formal', inclusive nos limites acima expostos. Uma norma de limitação do modelo de direito penal mínimo informada pela certeza e pela razão é o critério do favor rei, que não apenas permite, mas exige intervenções potestativas e valorativas de exclusão ou de atenuação da responsabilidade cada vez que subsista incerteza quanto aos pressupostos cognitivos da pena. A este critério estão referenciadas instituições como a presunção de inocência do acusado até a sentença definitiva, o ônus da prova a cargo da acusação, o princípio in dubio por reo, a absolvição em caso de incerteza acerca da verdade fática e, por outro lado, a analogia in bonam partem, a interpretação restritiva dos tipos penais e a extensão das circunstâncias eximentes ou atenuantes em caso de dúvida acerca da verdade jurídica. Em todos estes casos teremos certamente discricionariedade, mas se trata de uma discricionariedade dirigida não para estender,

\footnotetext{
${ }^{34}$ Luigi Ferrajoli. Direito e razão: teoria do garantismo penal. Tradução de Ana Paula Zomer et al. São Paulo: RT, 2002, p. 51-52.
} 
mas para excluir ou reduzir a intervenção penal quando não motivada por argumentos cognitivos seguros ${ }^{35}$.

E para fundar um sistema mais garantista, em prol de um direito penal mais racional e mínimo possível (legalidade estrita), deve o juiz, bem como o legislador, se afastar de termos imprecisos e proposições vagas e valorativas. Por isso, cabe ao sistema formular hipóteses legais taxativas, precisas, afastando-se de termos vagos e imprecisos, sem falar daqueles valorativos, que abram demasiadamente o leque de possibilidades de poder e decisão, quer do legislador, quer do juiz. O que vale tanto para o momento da cominação do crime (preceito primário: norma de conduta incriminadora) quanto para o momento da cominação e aplicação da pena (preceito secundário: pena).

David Teixeira de Azevedo, em Tese de Livre-Docência, assim dispôs:

O requisito da taxatividade é basilar para a compreensão da tipicidade das normas penais, muito especialmente para as normas sancionadoras penais. Ele veda ao intérprete o recurso da analogia como instrumental ou ferramental hermenêutico para cobertura de lacunas no ordenamento. Se não houve a definição prévia de sanção de natureza criminal, com potencialidade de atingimento do direito fundamental de liberdade, não poderá ser aplicada norma assemelhada, ainda que tutele o mesmo bem jurídico ou bem jurídico da mesma natureza. A lei fluida imprecisa, cujos termos são caracterizados pela vagueza, um dispositivo marcado pela porosidade não permite a delimitação do próprio conteúdo normativo. Se toda norma contém em si porosidade, tratando-se de imanente elasticidade de compreensão, o requisito da taxatividade tanto mais impõe ser o texto normativo definido com a maior precisão possível, mediante terminologia comum e unívoca, a permitir a compreensão imediata por parte dos destinatários e, sem deformação ou refração, possibilitar a impregnação da personalidade dos valores trazidos pelo modelo jurídico. Nessa ordem de pensamento, a sanção penal deve vazar-se em termos precisos, claros e bem delimitados. Deve-se utilizar a linguagem comum e evitar tortuosos caminhos de fiação da reprimenda e de sua modificação ou modulação durante o tempo da execução penal [...]. Taxativo, assim, é o que impede ou delimita o espaço hermenêutico, situando-o dentro dos limites democráticos do Estado de direito". 36

Obviamente, no que tange à fixação da pena, não é possível haver uma certeza absoluta de qual será a pena aplicada. Contudo, dentro de uma ideia de moldura de pena, deve-se evitar ao máximo uma ampla discricionariedade.

\footnotetext{
${ }^{35}$ Luigi Ferrajoli. Direito e razão: teoria do garantismo penal. Tradução de Ana Paula Zomer et al. São Paulo: RT, 2002, p. 84.

${ }^{36}$ David Teixeira Azevedo. Tipicidade e consequência jurídica do crime. Tese de Livre-Docência apresentada à Universidade de São Paulo, São Paulo, 2013, p. 305-306.
} 
Como bem fala Anabela Miranda Rodrigues, “a vinculação à lei do juiz no âmbito da valoração é, pois, incompatível com a possibilidade de uma multiplicidade de quantidades de penas poderem ser consideradas equivalentes no caso concreto" ${ }^{37}$, isto é: para um único fato praticado não podem corresponder inúmeras possibilidades de penas.

Por fim, a esse respeito, cabe ressaltar que a legalidade estrita não afasta, mas antes pressupõe uma atividade equitativa do juiz (a equidade). ${ }^{38}$ Luigi Ferrajoli explica exemplificando duas hipóteses:

\begin{abstract}
As duas teses 'Tício cometeu um roubo' e 'Caio cometeu um roubo' podem ser ambas verdadeiras e ambas conforme aos princípios da legalidade estrita e estrita jurisdicionariedade. Por hipótese, com efeito, tanto o fato individual de Tício quanto o de Caio foram provados e possuam, ambos, as características essenciais que foram a intensão ou conotação do conceito legal de roubo e que determinam seu campo de denotação. Mas isto não quer dizer que o roubo de Tício e o roubo de Caio sejam iguais, da mesma forma que a verdade tanto da tese 'P é uma mesa' quanto da tese 'Q é uma mesa' não comporta mais do que a extensão das duas teses, que as mesas 'P' e 'Q' sejam iguais. Os dois roubos de Tício e de Caio (como as duas mesas 'P' e 'Q') terão, na realidade, caracteres acidentais necessariamente diversos, de modo que as duas teses que enunciam sua comissão expressarão conteúdos informativos diferentes em relação às diferentes e não repetíveis conotações dos dois fatos denotados, ambos, pela lei como 'roubos'. As diferentes características acidentais dos dois roubos, isto é, suas conotações específicas, formam precisamente o objeto de compreensão e de valoração no juízo de equidade. De acordo com elas, é equitativo considerar que o roubo de um pedaço de pão, cometido por Tício em estado de necessidade, é muito menos grave do que o roubo de um banco de 1 milhão cometido por Caio; ou que uma ferida infligida por Tício em um momento de ira é menos grave que a mesma ferida infligida por Caio pelo gosto de seviciar. Conotações e valorações deste tipo, ainda que sendo estranhas à questão da verdade e da certeza das quais depende a legalidade do juízo, constituem um aspecto essencial e iniludível da cognição judicial e fazem com que todos os juízos sobre um mesmo tipo de delito, ainda que igualmente extensivos no plano legal quer dizer, igualmente verdadeiros ou igualmente falsos, jamais seriam equitativamente intensivos por igual, mas casa um sempre novo e diferente do precedente. ${ }^{39}$
\end{abstract}

Concluindo, Luigi Ferrajoli entende que a equidade é também uma condição de imparcialidade do juiz, pois não só seria iníquo o juiz que não consegue captar as

${ }^{37}$ Anabela Miranda Rodrigues. A determinação da medida da pena privativa de liberdade. Coimbra: Coimbra, 1995 , p. 95.

38 "A individualização das características particulares do fato e as conseqüentes valorações configuram a chamada equidade do juízo, na qual se expressa um poder que chamarei poder de conotação. É a esta atormentada, mas fundamental noção e aos numerosos equívocos comumente associados a ela que, agora, se dirigirá nossa análise" (Luigi Ferrajoli. Direito e razão: teoria do garantismo penal. Tradução de Ana Paula Zomer et al. São Paulo: RT, 2002, p. 125).

${ }^{39}$ Luigi Ferrajoli. Direito e razão: teoria do garantismo penal. Tradução de Ana Paula Zomer et al. São Paulo: RT, 2002, p. 128. 
especificidades do caso julgado, mas também aquele que alcunha seu julgamento com sua subjetividade, sem conseguir enxergar a subjetividade do acusado. ${ }^{40}$

Conferiu-se posição de destaque ao entendimento e modelo idealizado por Luigi Ferrajoli, confessando a autora ter abusado de suas citações e considerações, pois nesse modelo, a subjetividade do julgador não é desconsiderada. Ao contrário, ela é tomada em conta, e por aceitar-se a sua existência, inevitável influência e, frágil controle, propõe um sistema fechado, de legalidade estrita, no qual pequenas serão as margens para o arbítrio do julgador, pois não se é possível torná-lo absolutamente nulo.

Por ora, é importante apenas que já fique plasmada a ideia que será desenvolvida ao longo desse trabalho de que o Julgador, como homem que $\mathrm{e}^{41}$, e participante da sociedade que julgará, dela não se afasta no que tange a seus conceitos culturais, educacionais, não podendo

\footnotetext{
40 "Nesse sentido, a equidade é também uma condição de imparcialidade do juiz. É iníquo não só o juiz obtuso, que não sabe captar as conotações específicas do caso julgado, mas também o que faz pesar sua subjetividade no julgamento, sem conseguir e talvez sem sequer atentar desprender-se dela para compreender a do acusado. Assim se explica, conforme a configuração aqui avençada da equidade como conotação e compreensão dos casos concretos, como foi possível que a equidade tivesse sido concebida sempre como uma dimensão do juízo favorável ao réu; 'Ser indulgente com as coisas humanas é também equidade', quer dizer, ser como 'aquele que, afastando-se da justiça estrita e de seus piores rigores, sabe ceder'. Esta função da equidade não é apenas o fruto de uma opção política em favor do direito penal mínimo; nem deriva apenas de um princípio geral de tolerância para com as valorações quando estas não servem para punir o réu, mas para atenuar ou excluir a responsabilidade e a pena. Uma compreensão perfeita, que chega a penetrar por completo todas as conotações e os condicionamentos singulares - psicológicos, materiais e sociais - do caso específico, comportaria talvez, em muitos casos, a absolvição, conforme o princípio tout comprendre est tout pardonner. Naturalmente, isto é vedado pela estrutura legal do ordenamento, que na presença (da verificação) de um delito permite a absolvição apenas se concorrerem circunstâncias eximentes previstas na lei. Nada impediria, contudo - ao contrário, tudo aconselharia - a previsão legal de circunstâncias 'eximentes genéricas', análogas às 'atenuantes genéricas', cuja compreensão conduz à exclusão do delito. Uma figura desse tipo é, por exemplo, a do perdão judicial prevista no direito penal de menores, onde é maior o espaço concedido pela lei à compreensão equitativa. A lei, no mais, reconhece o favor rei como critério inspirador daquilo que chamamos de poder de conotação, prevendo como figura tipicamente equitativa somente as circunstâncias 'atenuantes genéricas' e não também as 'agravantes genéricas'. Sob este aspecto, parece-me em contradição com o princípio da equidade a previsão por parte da lei de limites mínimos, junto aos limites máximos de pena, para tipo de delito. Tal previsão, na realidade, não apenas contradiz o modelo de direito penal mínimo, mas humilha a função do juiz, ao não lhe consentir valorar plenamente a possível falta de qualquer gravidade do caso concreto, relativamente à gravidade do tipo de delito abstratamente valorada pela lei, conforme suas exclusivas conotações constitutivas, mediante a estipulação dos limites máximos". (Luigi Ferrajoli. Direito e razão: teoria do garantismo penal. Tradução de Ana Paula Zomer et al. São Paulo: RT, 2002, p. 132-133).

41،"A Ciência do Direito, especialmente no Brasil, ainda está muito imbuída de "racionalidade abstrata", no sentido de que a experiência jurídica possa toda ela ser reduzida a uma sucessão de silogismos ou de atos atribuíveis a uma entidade abstrata, ao "homo juridicus.". A técnica jurídica, operando com meros dados lógicoformais, vai, aos poucos, firmando a convicção errônea de que o juiz deve ser a encarnação desse mundo abstrato de normas, prolatando sentenças como puros atos de razão. Na realidade, sabemos que o juiz, antes de ser juiz, é homem partícipe de todas as reservas afetivas, das inclinações e das tendências do meio social, e que nós não podemos prescindir do exame dessas circunstâncias, numa visão concreta da experiência jurídica, por maior que deva ser necessariamente a nossa aspiração de certeza e objetividade." (Miguel Reale. Filosofia do Direito. $20^{\mathrm{a}}$ ed. São Paulo: Saraiva, p.136).
} 
se despir de seu natural recorte de vida, de suas próprias idiossincrasias, estando seu julgamento, desde logo, contaminado.

Dessa forma, por não se compartilhar do entendimento de que a sentença seja um ato mecânico, resultado de um mero silogismo ${ }^{42}$, no qual a premissa maior é a lei, a menor o caso, e a conclusão a decisão; negando-se, portanto, a existência de critérios valorativos morais do julgador, na fixação da pena; é que se entende necessário afastar do ordenamento jurídico as circunstâncias judiciais conduta social e personalidade, da fixação da reprimenda, em sua primeira fase, porque são portais para o arbítrio do juiz, nos termos bem esclarecidos por Luigi Ferrajoli, em seu sistema idealizado.

Por que se é verdade que não se pode negar a influência da subjetividade de qualquer intérprete sob o objeto analisado e tampouco retirá-la do ato decisório; sendo, destarte, precário ainda o controle dessa interferência, que requer um preparo, pouco desenvolvido, nos julgadores em geral $^{43}$. Então, entende-se premente e necessário o afastamento dessas condições, uma vez que, como ficará evidenciado nos Capítulos 2 e 3, não apresentam clareza de seu objetivo, abrindo uma margem muito grande para injustiças, para a projeção dos

\footnotetext{
${ }^{42}$ Aliás, esta ideia é originária de Cesare Beccaria que, no clássico Dos Delitos e Das Penas, dispõe que: "O juiz deve fazer um silogismo perfeito. A maior deve ser a lei geral: a menor, a ação conforme ou não à lei; a conseqüência, a liberdade ou a pena. Se o juiz for obrigado a elaborar um raciocínio a mais, ou se o fizer por sua conta, tudo se torna incerto e obscuro. [...] Cada homem tem a sua maneira de ver; e o mesmo homem, em épocas distintas, vê diversamente os mesmos objetos. O espírito de uma lei seria, pois, o resultado da boa ou da má lógica de um juiz, de uma digestão fácil ou penosa, da debilidade do acusado, da violência das paixões do magistrado, de suas relações com o ofendido, enfim, da reunião de todas as pequenas causas que modificam as aparências e transmutam a natureza dos objetos no espírito mutável do homem". (Cesare Beccaria. Dos Delitos e das Penas. Tradução de Torrieri Guimarães. São Paulo: Editora Martin Claret, 2004, p. 22-23).

43 “a) verificou-se, filosoficamente, uma total impossibilidade de apreensão e transmissão cognitiva de forma inteiramente neutra e desvinculada de aspectos representativos da subjetividade do indivíduo cognoscente/transmissor. Para além de uma equivocada noção que jamais teve como possuir o reforço de uma comprovação cabal empírica ou fática, o sujeito cientista neutro é muito mais uma construção idealizada por epistemes paradigmáticas que com ela se mostravam coniventes (do ponto de vista de uma História das Ideias) do que uma realidade crível, não se sustentando, a ideia, diante de um embate filosófico-crítico mínimo (o que hoje é corroborado, igualmente pelo saber das neurociências, bem como pelas hodiernas teorias psicológicas). Não obstante essa verificada incongruência na crença em um modelo científico de sujeito cognoscente neutro, a epistemologia jurídica segue trabalhando nos moldes de uma filosofia da consciência de forte (ainda que velada, omitida ou mesmo despercebida) inspiração cartesiana: a preparação-padrão para o exercício da atividade jurisdicional (sobretudo jurisdicional-decisória) é pródiga em desconsiderar a problemática psíquico-subjetiva da pessoa do Magistrado, e permite a entrada no mercado de profissionais forjados em um delineamento essencialmente técnico-legalista, na maioria das vezes, sem um necessário reforço doutrinário de ordens deontológica e zetética e sem serem dotados de qualquer postura crítica quanto à importância da discussão sobre a (im)possibilidade de neutralidade no exercício das funções atinentes à própria atividade-fim. Ao contrário: a problemática, na maioria das vezes, é sonegada da agenda "necessária" de discussão;" (Gabriel Antinolfi Divan. Decisão judicial nos crimes sexuais: o julgador e o réu interior. Porto Alegre: Livraria do Advogado Editora, 2010, p. 186).
} 
conteúdos internos e desconhecidos dos julgadores em seus réus; não havendo razões para sua mantença, pelos motivos que melhor serão abordados nos Capítulos seguintes. 


\section{CIRCUNSTÂNCIAS JUDICIAIS PESSOAIS DO ARTIGO 59 DO CÓDIGO PENAL}

\subsection{Breves observações introdutórias sobre as finalidades da pena}

A pena decorre do sancionamento de uma conduta praticada pelo agente que é desvalorada pelo direito e pela sociedade como um todo. Obviamente, pressupõe-se no agir humano uma margem de liberdade, sem a qual não seria possível justificar a aplicação de reprimenda. Afinal, só se pune o sujeito que pode se conduzir livremente. Não fosse isso possível, não haveria sentido em se punir.

Sabe-se hoje que essa liberdade não é total. Ninguém é totalmente livre ${ }^{44}$. Estamos condicionados por uma série de fatores, segundo a neurociência. Somos todos, de certa forma, pessoas neuróticas e compulsivas, conforme mostra a moderna psicologia, haja vista a perda da liberdade total e plena, que nutríamos no estado de natureza, para que pudéssemos viver em sociedade.

De toda forma, é difícil negar que o sujeito não tenha certa margem de escolha na sua conduta. É a eterna briga entre o princípio do livre-arbítrio ${ }^{45}$ e o do determinismo ${ }^{46}$, sendo que há argumentos para privilegiar tanto um quanto outro ponto de vista.

\footnotetext{
44 "O você consciente - o eu que ganha vida quando você acorda pela manhã - é a menor parte do que se revela de seu cérebro. [...] Sua consciência é como um passageiro clandestino mínimo em um vapor transatlântico, assumindo o crédito pela viagem sem dar pela presença da maciça engenharia sob seus pés. [...] Como observa Carl Jung: "Em cada um de nós há um outro que não conhecemos." Como diz o Pink Floyd: "Tem alguém na minha cabeça, mas não sou eu."'” (David Eagleman. Incógnito: as vidas secretas do cérebro. Tradução de Ryta Vinagre. Rio de Janeiro: Rocco, 2012, p. 12-16).

45 "As consequências das controvérsias humano-biológicas para a justiça penal são evidentes. Pode-se apenas recomendar à justiça penal que contorne amplamente essa controvérsia. Se ela se deixar arrastar pela controvérsia, então seu trabalho chegou ao fim. Ela não tem escolha, seu problema é estrutural e não pode ser resolvido com boa vontade e uma postura aberta: A justiça penal tem tarefas, cuja realização, também no interesse de melhores compreensões futuras, não pode ser postergada, e essas tarefas apresentam-se modo transversal à opinião do determinismo humanobiológico. A justiça penal deve, dia a dia, avaliar se alguém é ou não imputável, se agiu dolosa ou culposamente, se circunstâncias mitigadoras em sua personalidade o favorecem. Com cada avaliação desta natureza, a justiça penal pressupõe faticamente a possibilidade do livre arbítrio e da culpabilidade e a reconhece. Ela não pode postergar suas decisões até o fim da controvérsia sobre o livre arbítrio, o que pode durar décadas ou séculos, ou seja: ela não pode fazer valer para si o determinismo. Os juízes e promotores precisam executar o princípio da culpabilidade durante a semana e somente no fim de semana poderiam redigir um parecer inflamado a favor do determinismo. Vislumbra o leitor um fim deste dilema ou mesmo uma solução deste problema? Eu não." (Winfried Hassemer. Neurociências e culpabilidade em direito penal. Revista Brasileira de Ciências Criminais, São Paulo, volume 100, 2013. Tradução de Helena Regina Lobo da Costa, p. 214).
} 
$\mathrm{Na}$ verdade, isso mostra que "apesar de existir um grau de causalidade em nossas ações e eleições, entretanto, manteríamos certa porcentagem de liberdade nelas. Determinismo e causalidade são compatíveis em suas versões fracas" ${ }^{\text {47 }}$.

Para que alguém seja penalmente responsável, não é necessária uma conduta totalmente livre, mas que seja livre de uma influência que se mostre irresistível.

A pena é um mal, pois acarreta uma dor e sofrimento a alguém que praticou uma conduta considerada desvaliosa. O castigo, nesse sentido, constitui um mal, sendo que os Códigos Penais são nada mais que leis da dor. Sendo o delito um evento desvalorado pelo direito, castiga-se o crime para que se retribua um mal (o fato praticado) com outro mal (a pena). Nítido o caráter retributivo da pena, que não pode ser negado.

Como aponta Miguel Reale Júnior, “a pena é vivida e sentida por todos, réu, vítima, sociedade, operadores do Direito, como um castigo, e este dado de cunho retributivo concretamente aferido não pode deixar de ter o seu peso na análise do significado da pena, que não constitui um significado de experimentação nos gabinetes dos penalistas, mas que é um fenômeno da realidade a ser compreendido" 48

Contudo, ao lado da retribuição, aponta-se a necessidade de haver algumas finalidades preventivas à pena, principalmente, em função do que dispõe o artigo 59 do Código Penal, na medida em que disciplina que a fixação da pena, entre os limites mínimo e máximo, deverá servir, por um lado, à justa retribuição da culpabilidade, e por outro, a um fim preventivo.

\footnotetext{
46 "Em efecto, como también sabemos, algunos de los protagonistas de la investigación neurocientífica, y algunos penalistas, piensan que lo que se está descubriendo en estos últimos años acerca del funcionamento del cérebro, específicamente, acerca de cómo tienen lugar los procesos de toma de decisiones, revelan que nuestros puntos de partida fundamentales a la hora de establecer la responsabilidad penal estarían errados. ... Entonces, si es cierto, como afirman los (rectius: algunos) neurocientíficos, que en realidad las decisiones - todas las decisiones - no se toman em aquel estrato del cérebro que llamamos "yo", es decir, por parte de las estructuras neuranales que configuran la conciencia; sino que la decisión em realidad se acomoda a procesos neuronales no conscientes, en suma, si es cierto que no "hacemos lo que queremos", sino que "queremos lo que hacemos" (Prinz), todo el edifício de la responsabilidad jurídico-penal debería caer por su base, y, com él, todo nuestro sistema penal basado em la libertad de elección, el reproche y la culpabilidad, para dar paso a um nuevo modo de tratar el comportamiento desviado, asentado sobre la perigrosidad y su tratamiento, y no sobre la culpabilidad y su castigo." (Manuel Cancio Meliá. Psicopatía y Derecho Penal: Algunas Consideraciones Introductorias. p. 529530. Disponível em: <http://www.fder.edu.uy/contenido/penal/cancio.pdf $>$. Acesso em: $13 \mathrm{dez} .2013)$.

${ }^{47}$ Fernando Falcón y Tella e Maria José Falcón y Tella. Fundamento e finalidade da sanção: existe um direito de castigar? Tradução de Claudia de Miranda Avena. São Paulo: RT, 2008, p. 163.

${ }^{48}$ Miguel Reale Júnior. Instituições de direito penal. $3^{\text {a }}$ ed. Rio de Janeiro: Forense, 2009, p. 57.
} 
Em função de o objetivo deste trabalho estudar a conduta social e personalidade como circunstâncias, a serem avaliadas pelos magistrados, para o alcance dessa dupla finalidade da reprimenda penal, é que se julgou necessário tecer, abaixo, breves esclarecimentos sobre as finalidades da pena.

Passemos ao estudo das finalidades da pena.

\subsubsection{Finalidade retributiva da pena (teorias absolutas)}

A retribuição penal, vista como finalidade da sanção penal, decorre de Kant e de Hegel. Em Kant, a pena é vista como um imperativo categórico, sendo decorrência de uma necessidade ética. Nada mais que isso. Dever-se-ia retribuir com a pena o mal causado pelo infrator. Já em Hegel, que veio a melhor desenvolver o conceito jurídico de pena, tem-se que a pena seria a negação do delito, o qual seria nada mais que a negação do direito, de modo que a negação da negação restabeleceria a paz.

Argumenta-se contra a finalidade retributiva da pena, já que, supostamente, não haveria racionalidade em se pagar um mal com outro mal, sendo que, por isso mesmo, "a ideia de retribuição não pode ser explicada racionalmente, mas tão somente como uma expressão de uma crença" ${ }^{49}$. Na verdade, a objeção não procede.

Conforme afirma José de Faria Costa, "o princípio da retribuição nada tem de metafísico ou irracional e que é antes um pilar da mundividência e vivência ética que percorre todo o nosso pensamento jurídico" ${ }^{„ 5}$. Segundo Guilherme de Souza Nucci, não é incogitável, ou mesmo irracional, retribuir o mal com o mal, pois, "na verdade, não se trata de algo ‘impensável', mas simplesmente uma realidade, passível de verificação prática. O ser humano sofre castigos a vida toda, de variadas maneiras, desde o berço até a fase madura, bastando

\footnotetext{
${ }^{49}$ Fernanda Ravazzano Lopez Baqueiro. As funções não declaradas da ressocialização e a tentativa do discurso legitimador. Ciências penais, São Paulo, ano 6, n. 11, jul.-dez./2009, p. 247.

${ }^{50}$ José de Faria Costa. Linhas de direito penal e de filosofia: alguns cruzamentos reflexivos. Coimbra Editora, 2005, p. 209.
} 
que, para isso, desvie-se do caminho considerado 'correto' pelas inúmeras regras sociais, éticas, morais ou legais" ${ }^{, 51}$.

Pertinente a observação de Víctor Gabriel Rodríguez de que "não se pode dizer que a concepção kantiana seja reducionista, ou seja, pouco refletida simplesmente porque não concede à pena uma função transcendente, que ultrapasse o indivíduo e o mal causado. Na verdade, a concepção kantiana é muito coerente com a sua ideia de fundamentação ética da norma: a pena deixa de ser uma retribuição moral e desaparece a preocupação com os efeitos que ela possa causar no condenado ou na sociedade como um todo. Isso, porém, é proposital. Afinal, Kant elaborava o pensamento de que, se a pena tivesse um fim social, político, o condenado seria utilizado como um instrumento para a pacificação social. E, se o homem é um fim em si mesmo, ele não pode ser instrumentalizado para o bem da coletividade" ${ }^{, 52}$.

É difícil, hoje em dia, encontrar autores que focam a finalidade da pena apenas na retribuição. Cita-se, a esse respeito, Janaina Conceição Paschoal, para quem a melhor forma de prevenção se perfaz com a retribuição justa, residindo aí, na verdade, a principal finalidade da pena.

De toda forma, mesmo a doutrina, que se mostra mais reticente à retribuição como uma finalidade da pena, reconhece que, de fato, uma "importante contribuição foi deixada pela teoria retribucionista: somente dentro dos limites da justa retribuição é que se justifica a sanção penal. Com efeito, a principal virtude desta concepção retributiva é a idéia de medição de pena, o que podemos chamar de princípio da proporcionalidade, dado informativo de qualquer moderna legislação penal" ${ }^{, 53}$.

\subsubsection{Finalidade preventiva da pena (teorias relativas)}

Mais que, meramente, causar um mal (pena) pelo mal praticado (delito), passou-se a entender que a pena, antes que uma mera retribuição pelo dano, deveria trazer alguma

\footnotetext{
${ }^{51}$ Guilherme de Souza Nucci. Individualização da pena. 2. ed. São Paulo: RT, 2007, p. 77.

${ }^{52}$ Víctor Gabriel Rodríguez. Fundamentos de Direito Penal Brasileiro. São Paulo: Atlas, 2011, p. 17.

${ }^{53}$ Alceu Corrêa Júnior e Sérgio Salomão Shecaira. Teoria da pena: finalidades, direito positivo, jurisprudência e outros estudos de ciência criminal. São Paulo: RT, 2002, p. 131.
} 
utilidade para a sociedade e para o indivíduo. A tônica deveria se dar na prevenção do delito, e não na repressão. A esse respeito, Cesare Beccaria afirmava que seria melhor prevenir os crimes que puni-los.

Das simples considerações das verdades até aqui expressas advém a evidência de que a finalidade das penalidades não é torturar e afligir um ser sensível, nem desfazer um crime que já está praticado. Como pode um organismo político que, em lugar de se dar às paixões, deve ocupar-se exclusivamente em colocar um freio nos particulares, exercer crueldades inócuas e utilizar o instrumento do furor, do fanatismo e da covardia dos tiranos? Poderão os gritos de um desgraçado nas torturas tirar do seio do passado, que não volta mais, uma ação já praticada? Não. Os castigos têm por finalidade única obstar o culpado de tornar-se futuramente prejudicial à sociedade e afastar os seus concidadãos do caminho do crime. Entre as penalidades e no modo de aplicá-las proporcionalmente aos delitos, é necessário, portanto, escolher os meios que devem provocar no espírito público a impressão mais eficaz e mais durável e, igualmente, menos cruel no corpo do culpado. ${ }^{54}$

A concepção da prevenção, como o próprio nome diz, tem função de prevenir delitos ${ }^{55}$. Assim, enquanto a retribuição visa o passado, a prevenção visa o futuro.

As teorias da prevenção são também conhecidas por teorias relativas, em contraposição às absolutas, pois as necessidades da prevenção são sempre relativas e circunstanciais. E se bifurcam entre prevenção geral e especial.

Prevenção geral é aquela que se dá perante a coletividade.

No antigo regime, a prevenção geral era exercida por meio das penas e execuções efetivadas perante a coletividade.

Modernamente, a prevenção vem sendo focada não mais na ideia do terror (ou terrorismo penal - seja em âmbito legislativo ou judicial), mas na de intimidação ${ }^{56}$, a qual tem sido muito questionada, já que é difícil afirmar, categoricamente, que a pessoa deixe, de fato, de cometer o delito por medo da futura aplicação da pena.

\footnotetext{
${ }^{54}$ Cesare Beccaria. Dos delitos e das penas. Tradução de Torrieri Guimarães. São Paulo: Editora Martin Claret, 2004, p. 49.

${ }^{55}$ Santiago Mir Puig. Direito penal: fundamentos e teoria do delito. Tradução de Cláudia Viana Garcia e José Carlos Nobre Porciúncula Neto. São Paulo: RT, 2007, p. 62.

56 "Reconhece, também, a sociedade um fim preventivo, intimidatório na pena, na crença inabalável de que a ligação imediata entre crime e punição desestimula os demais a praticar fatos delituosos pois paira a ameaça, como realidade visível, de que nesta hipótese haverá uma sanção.” (Miguel Reale Júnior. Instituições de direito pena: parte geral. $3^{\mathrm{a}}$ ed. Rio de Janeiro: Forense, 2009, p. 43).
} 
Contudo, o fato é que se revela complicadíssimo negar, peremptoriamente, que não exista essa intimidação. Sopesados os excessos e posições radicais - seja para defender um ponto de vista ou outro, é de se convir e concordar com parte da doutrina quando afirma que a criminalidade aumenta de forma significativa quando a policia entra em greve. ${ }^{57}$

Passemos à análise dessas questões.

\subsubsection{Prevenção geral negativa}

A pena deveria produzir um efeito de intimidação em relação à generalidade das pessoas, para que estas não cometam atos da mesma magnitude. Conforme apontam Alejandro Alagia, Alejandro Slokar, Eugenio Raúl Zaffaroni e Nilo Batista, o modelo da prevenção geral negativa são Feuerbach e Romagnosi ${ }^{58}$, partindo-se da premissa de que ao praticar o delito o sujeito sempre faria uma comparação custo-benefício entre o benefício decorrente do crime e o malefício proveniente da respectiva sanção ${ }^{59}$.

Assim, quanto mais duras fossem as penas, haveria um maior contraestímulo para que a generalidade das pessoas não praticasse mais crimes.

Como relata a doutrina, a "história do Brasil é repleta de exemplos de aplicação de penas que tinham efeito de desestimular os potenciais criminosos ao cometimento de crimes, a exemplo da utilização do pelourinho e da morte na forca, sempre realizada em praça pública, de grande visibilidade" 60 .

Dos anos de 1990 até hoje, Sérgio Salomão Shecaira cita várias leis que maximizaram a intervenção punitiva, com base em um possível efeito dissuasório da pena; cita a Lei dos Crimes Hediondos, a Lei de Falsificação de remédios, a Lei de Arma de Fogo, o Código de

\footnotetext{
${ }^{57}$ Fernando Falcón y Tella e Maria José Falcón y Tella. Fundamento e finalidade da sanção: existe um direito de castigar? Tradução de Claudia de Miranda Avena. São Paulo: RT, 2008, p. 205. Vide também: Miguel Reale Júnior. Instituições de direito penal: parte geral. 3. ${ }^{\mathrm{a}}$ ed. Rio de Janeiro: Forense, 2009, p. 54.

${ }^{57}$ Alejandro Alagia et al. Direito Penal Brasileiro: teoria geral do direito penal. Rio de Janeiro: Revan, 2003, p. 115.

${ }^{58}$ Alejandro Alagia et al. Direito Penal Brasileiro: teoria geral do direito penal. Rio de Janeiro: Revan, 2003, p. 115.

${ }^{59}$ Alejandro Alagia et al. Direito Penal Brasileiro: teoria geral do direito penal. Rio de Janeiro: Revan, 2003, p. 117.

${ }^{60}$ Víctor Gabriel Rodríguez. Fundamentos de Direito Penal Brasileiro. São Paulo: Atlas, 2011, p. 19.
} 
Trânsito, a Lei do Meio Ambiente, entre diversas outras leis no plano econômico, fenômeno que pode ser qualificado como a expansão do direito penal ${ }^{61}$.

Um inconveniente dessa ideia é que a pena tenderia levar ao "terror penal", pois "quanto maior a pena, teoricamente seria mais eficaz a prevenção"62. "o que implicaria um dever moral de graduá-la ao máximo"63. Argumenta-se contra essa finalidade da pena, pois ela propiciaria uma punição exemplar, punindo-se o agente não pela sua punibilidade em si, mas para servir de exemplo aos demais, o que, de fato, atentaria contra o Estado Democrático de Direito, segundo Alceu Corrêa Júnior e Sérgio Salomão Shecaira ${ }^{64}$.

Ademais, quanto mais freqüente um delito, o fato é que, para a sua prevenção, maior deveria ser a pena. Como relatam, entre outros, Eugênio Raúl Zaffaroni e Nilo Batista, "a pena não manteria qualquer relação com o conteúdo do injusto do fato praticado, mas sim sua medida dependeria de fatos alheios. Em situações de crise econômica, os delitos contra a propriedade tendem a aumentar e, segundo a lógica dissuasória, as penas deveriam aumentar; ou seja, para essa lógica, durante as crises econômicas as penas devem ser maiores para os mais prejudicados" ${ }^{\prime 2}$. Levando-se às ultimas consequências essa lógica, os delitos patrimoniais, porque mais frequentes, ainda que sem violência, deveriam ser apenados de modo mais rígido que um delito mais grave, como um homicídio, o que configuraria um completo nonsense.

No mesmo sentido pondera Santiago Mir Puig que, de fato, se deve ter cautela com ditas teorias, pois poderiam levar ao terror estatal, ou, senão, poderiam acarretar a cominação de penas altas a delitos que se praticam com certa freqüência, entre eles, aqueles de pouca ou baixíssima lesividade, como pequenos furtos a supermercados; as penas assim seriam aumentadas para frear os impulsos criminosos de todos, o que se afiguraria inadmissível, por

\footnotetext{
${ }^{61}$ Sérgio Salomão Shecaira. Pena e política criminal. A experiência brasileira. In: Alvino Augusto de Sá e Sérgio Salomão Shecaira (orgs.). Criminologia e os problemas da atualidade. São Paulo: Atlas, 2008, p. 333-334.

${ }^{62}$ Alceu Corrêa Júnior e Sérgio Salomão Shecaira. Teoria da pena: finalidades, direito positivo, jurisprudência e outros estudos de ciência criminal. São Paulo: RT, 2002, p. 131.

${ }^{63}$ Alceu Corrêa Júnior e Sérgio Salomão Shecaira. Teoria da pena: finalidades, direito positivo, jurisprudência e outros estudos de ciência criminal. São Paulo: RT, 2002, p. 132.

${ }^{64}$ Alceu Corrêa Júnior e Sérgio Salomão Shecaira. Teoria da pena: finalidades, direito positivo, jurisprudência e outros estudos de ciência criminal. São Paulo: RT, 2002, p. 131.

${ }^{65}$ Alejandro Alagia et al. Direito Penal Brasileiro: teoria geral do direito penal. Rio de Janeiro: Revan, 2003, p. 119-120.
} 
atentar contra o princípio da proporcionalidade das penas ${ }^{66}$. Por outro lado, ainda com essa (equivocada) concepção de prevenção (se levada ao extremo), sempre haveria o perigo de fatos da máxima "reprovabilidade" ou de altíssima "danosidade social" serem apenados com penas menores, justamente porque a "sua gravidade, socialmente sancionada, constitui um eficaz freio que torna muito menos necessário recorrer à pena estatal"67. Pense-se assim: já que o número de casos de filhos que matam os pais é reduzido em relação aos casos de crimes patrimoniais, não seria necessário prever penas maiores àqueles em relação a estes - já que se repetem continuamente.

Deve-se concluir que a prevenção geral não pode contradizer os valores sociais, de maneira que, conforme assevera Santiago Mir Puig, isso não quer dizer que a prevenção, tomadas e guardadas as devidas proporções, não seja um meio adequado para se legitimar corretamente o bom uso do direito penal ${ }^{68}$.

Argumenta-se, outrossim, contra a teoria da prevenção geral negativa, que o efeito da intimidação não é certo, sendo muitíssimo questionável, já que "os motivos que levam ao delito são complexos" ${ }^{\prime 69}$.

$\mathrm{Na}$ verdade, a punição exemplar (rigorismo penal, ou melhor, o terror penal) não é e nem nunca foi a melhor forma de prevenção. Muito melhor a certeza de uma punição (ainda que mais branda) que a alta probabilidade de impunidade de uma pena mais rigorosa.

A esse respeito, já alertava Cesare Beccaria que:

o rigor do suplício não é o que previne os delitos com maior segurança, porém a certeza da punição, o zelo vigilante do juiz e essa severidade inalterável que só é uma virtude no magistrado quando as leis são brandas. A perspectiva de um castigo moderado, porém inflexível, provocará sempre uma impressão mais forte do que o vago temor de um suplício horrendo, em relação ao qual aparece alguma esperança de impunidade. ${ }^{70}$

\footnotetext{
${ }^{66}$ Santiago Mir Puig. Direito penal: fundamentos e teoria do delito. Tradução de Cláudia Viana Garcia e José Carlos Nobre Porciúncula Neto. São Paulo: RT, 2007, p. 64-65.

${ }^{67}$ Santiago Mir Puig. Direito penal: fundamentos e teoria do delito. Tradução de Cláudia Viana Garcia e José Carlos Nobre Porciúncula Neto. São Paulo: RT, 2007, p. 66.

${ }^{68}$ Santiago Mir Puig. Direito penal: fundamentos e teoria do delito. Tradução de Cláudia Viana Garcia e José Carlos Nobre Porciúncula Neto. São Paulo: RT, 2007, p. 66.

${ }^{69}$ Víctor Gabriel Rodríguez. Fundamentos de Direito Penal Brasileiro. São Paulo: Atlas, 2011, p. 19.

${ }^{70}$ Cesare Beccaria. Dos delitos e das penas. Tradução de Torrieri Guimarães. São Paulo: Editora Martin Claret, 2004, p. 64.
} 
Por isso, procede a afirmação de Eduardo Reale Ferrari quando sugere que existe, de fato, um viés inibitório quando há certeza da punição. O autor se manifesta nesses termos:

\begin{abstract}
ainda que coloquemos em causa a eficácia da intimidação na cominação das normas, não chegaria ao ponto de negar relevância à intimidação, enquanto execução de todo modo secundária, se comparada ao fim de prevenção geral positiva. A pena tem um fim de intimidação, resultante da rapidez e seriedade em sua execução, e não de sua cominação legal abstrata. Ainda que possível que muitos delinquentes não se atemorizem com a cominação da sanção, entendemos possível o efeito inibitório à conduta, se presente a relativa rapidez e seriedade em sua execução. Mesmo que a cominação tenha um efeito inibitório inicial, frustrante será o seu fim, se inerte a operatividade $^{71}$.
\end{abstract}

A intimidação, tal qual pensada na teoria geral negativa, de toda forma, resta vulnerada pelo argumento das altas cifras negras (ou douradas, nos crimes dos mais abastados) e da alta seletividade do sistema, já que, existindo esses fatores de desfuncionalidade da justiça penal, a intimidação perde muito de sua força. Afinal, uma justiça débil, que não consegue repreender e sequer apurar grande parte dos fatos supostamente delituosos não tem o condão de intimidar quem quer que seja.

Tem-se entendido que a intimidação, ou melhor, inibição da tendência de delinqüir, não deve ser a única função do direito penal (ou finalidade principal), devendo existir aquilo que se denomina por "afirmação positiva do direito", ou de uma atitude de respeito ao direito. É a conhecida função geral positiva, "estabilizadora" ou "integradora",72, que Helena Regina Lobo da Costa bem adverte a respeito da sua diversidade, ao tratar, em sua obra, acerca das teorias da prevenção geral positiva, com foco na sua compatibilidade com o respeito à dignidade da pessoa humana ${ }^{73}$. Passemos à sua análise.

\footnotetext{
${ }^{71}$ Eduardo Reale Ferrari. Medidas de segurança e direito penal no Estado Democrático de Direito. São Paulo: RT, 2001, P. 54.

${ }^{72}$ Santiago Mir Puig. Direito penal: fundamentos e teoria do delito. Tradução de Cláudia Viana Garcia e José Carlos Nobre Porciúncula Neto. São Paulo: RT, 2007, p. 64.

${ }^{73}$ Helena Regina Lobo da Costa. Dignidade humana: teorias de prevenção geral positiva. São Paulo: RT, 2008. Em nosso ordenamento jurídico a autora tratou profundamente do assunto, sendo que, no exterior, conhecido é também o entendimento de Santiado Mir Puig que procura diferenciar uma tendência da prevenção geral (1) fundamentadora do direito de punir e (2) limitadora do direito de punir. Aquela teria como expoentes Hans Welzel e Jakobs, que levam a uma expansão antigarantista do direito penal, e a de Claus Roxin e Hassemer (teoria limitadora), que conferem balizas seguras a um direito penal mais racional. Tratando especificamente sobre isso, vide também: Fernando Falcón y Tella e Maria José Falcón y Tella. Fundamento e finalidade da sanção: existe um direito de castigar? Tradução de Claudia de Miranda Avena. São Paulo: RT, 2008, p. 211-212.
} 


\subsection{Prevenção geral positiva}

Ao lado da prevenção geral negativa, de função intimidatória da pena, para que a generalidade das pessoas se abstenha de praticar crimes, haveria uma finalidade preventiva geral, integradora, na medida em que ao se punir se estabelece a confiança das pessoas na força da lei (confirmação da norma). Com a aplicação da pena, haveria um efeito positivo em relação aos terceiros não criminalizados, "não porém para dissuadi-los pela intimidação, e sim como valor simbólico produtor de consenso, e, portanto, reforçador de sua confiança no sistema social em geral (e no sistema penal em particular ${ }^{\text {"74 }}$.

Aqui, nesta vertente, há uma corrente mais radical e outra mais moderada, de modo que (1) para os adeptos da corrente fundamentadora das penas (teoria mais radical, de Jakobs) haveria apenas a finalidade de reafirmação do ordenamento e de seus valores, ao passo que (2) para os adeptos da corrente da prevenção geral positiva limitadora (Claus Roxin) "a finalidade da pena deve ser restringida pelos princípios da intervenção mínima, da proporcionalidade, da ressocialização, da culpabilidade, etc" ${ }^{\text {75 }}$.

$\mathrm{Na}$ verdade, pioneira e muito interessante a observação de Helena Regina Lobo da Costa ao observar que, dadas as diferentes concepções da prevenção geral positiva, não existe apenas uma corrente de prevenção geral positiva, mas sim "teorias de prevenção geral positiva", conforme está logo expresso no título de sua obra ${ }^{76}$.

Segundo expõe Helena Regina Lobo da Costa, "se considerados os limites formais e materiais que devem se impor a qualquer concepção de finalidades da pena em um Estado Democrático de Direito, entre eles os decorrentes da dignidade humana como princípio e como postulado normativo, a prevenção geral positiva exsurge como finalidade legítima e adequada ao direito penal contemporâneo"77. Na América Latina (Argentina), outro grande

\footnotetext{
${ }^{74}$ Alejandro Alagia et al. Direito Penal Brasileiro: teoria geral do direito penal. Rio de Janeiro: Revan, 2003, p. 121. (destaques do autor).

${ }^{75}$ Alceu Corrêa Júnior e Sérgio Salomão Shecaira. Teoria da pena: finalidades, direito positivo, jurisprudência e outros estudos de ciência criminal. São Paulo: RT, 2002, p. 132.

${ }^{76}$ Helena Regina Lobo da Costa. Dignidade humana: teorias de prevenção geral positiva. São Paulo: RT, 2008.

${ }^{77}$ Helena Regina Lobo da Costa. Dignidade humana: teorias de prevenção geral positiva. São Paulo: RT, 2008, p. 163. Frisando a finalidade preventiva geral positiva da pena em qualquer momento da persecução penal, desde que "devidamente limitada pelos princípios constitucionais": Fernando Vernice dos Anjos. Análise crítica da finalidade da pena na execução penal: ressocialização e o direito penal brasileiro. Dissertação de Mestrado apresentada à Universidade de São Paulo, 2009, p. 149.
} 
expoente e defensor da prevenção geral positiva é Enrique Bacigalupo, o qual afirma que "uma teoria como esta permite superar a crítica das outras teorias absolutas baseada em sua irracionalidade, vale dizer, na ausência de uma finalidade social que justifique a aplicação das penas" ${ }^{, 78}$.

Com efeito, conquanto a pena tenha a finalidade de estabilizar a vigência da norma violada pelo autor, adquire uma função social utilitária, consistente na comunicação de uma determinada mensagem destinada a fortalecer a confiança na vigência da norma infringida. Por isso, constitui um meio para lograr um fim socialmente positivo. Tudo isso não exclui, como fica claro, a possibilidade de uma articulação da teoria da prevenção geral positiva com teorias absolutas na forma própria das teorias da união ${ }^{79}$.

As teorias da prevenção geral positiva suscitam, contudo, seja na doutrina nacional, seja na estrangeira, muitos questionamentos ${ }^{80}$.

Víctor Gabriel Rodríguez fala que "por útil que seja a pena à coletividade, e por mais que a prevenção geral positiva aponte para um fim construtivo da pena, a crítica kantiana deve ser levada em consideração: quando se condena alguém não por castigo a seu próprio pecado, mas para que a sociedade sinta um valor positivo do ordenamento, ou uma intimidação, está-se visando a uma finalidade utilitarista" ${ }^{\prime 81}$. Na verdade, a crítica, de todo, não procede, pois a reafirmação de valores também tutela a dignidade do próprio ofensor, já que o mesmo estará protegido de ataques contra a sua pessoa. Enfim, não há uma instrumentalização do condenado pelo resto da comunidade, pois também ele se beneficia da reafirmação de valores caros para a sociedade e para ele próprio (respeito à vida, à honra, ao patrimônio, à correta administração pública, à autodeterminação sexual, etc).

\footnotetext{
${ }^{78}$ Enrique Bacigalupo. Direito Penal: parte geral. Tradução de André Estefam. São Paulo: Malheiros, 2005, p. 33.

${ }^{79}$ Enrique Bacigalupo. Direito penal: parte geral. Tradução de André Estefam. São Paulo: Malheiros, 2005, p. 33-34.

80 “A prevenção geral positiva observa, em certa medida, dados que são reais, porém sua falha mais notória é de natureza ética: legitima o que acontece pelo simples objetivo de que continue acontecendo, pois não passa disso reforçar positivamente o sistema, elevado assim a um valor supremo e imutável" (Alejandro Alagia et al. Direito Penal Brasileiro: Teoria Geral do Direito Penal. Rio de Janeiro: Revan, 2003, p. 124).

${ }^{81}$ Víctor Gabriel Rodríguez. Fundamentos de Direito Penal Brasileiro. São Paulo: Atlas, 2011, p. 21.
} 
Há quem sugira que a prevenção geral positiva nada mais constituiria que uma decorrência da tese hegeliana de negação de delito (a negação da negação neutralizaria o mal do delito), vendo "uma ponte entre essa teoria preventiva e Hegel" 82 .

Eugênio Raúl Zaffaroni, um ferrenho crítico da prevenção geral positiva, afirma que ela pretende legitimar o status quo, na medida em que apela para o caráter meramente simbólico da pena: ainda que opere em relação a um número reduzido de indivíduos (bodes expiatórios do sistema), a teoria poderia conviver com a seletividade do sistema penal (já que o efeito integrativo é apenas e meramente simbólico) e com as altas cifras negras, as quais tanto causam problemas às demais teorias da pena, em especial à teoria da prevenção geral na vertente negativa (intimidação), conforme já tivemos oportunidade de analisar mais acima.

\subsubsection{Prevenção especial}

Diferente da prevenção geral, que mira a coletividade, a prevenção especial tem especial foco no sujeito delinqüente singularmente considerado. Como colocam Fernando Falcón y Tella e María José Falcón y Tella, o ideal aqui está em castigar da forma melhor e mais proveitosa possível ${ }^{83}$.

\subsection{Prevenção especial negativa}

A prevenção especial negativa tem o fim de neutralização do delinquente. É um efeito imediato que decorre, geralmente, do cumprimento da pena. Fala-se geralmente, pois, uma vez preso, nem sempre o recluso deixa de cometer delitos, já que os comete dentro do presídio, sendo que, hoje em dia, não é incomum que mande executar crimes na rua, de dentro da instituição carcerária.

\footnotetext{
${ }^{82}$ Alejandro Alagia et al. Direito Penal Brasileiro: teoria geral do direito penal. Rio de Janeiro: Revan, 2003, p. 121-122.

${ }^{83}$ Fernando Falcón y Tella e Maria José Falcón y Tella. Fundamento e finalidade da sanção: existe um direito de castigar? Tradução de Claudia de Miranda Avena. São Paulo: RT, 2008, p. 218.
} 
Não é um fim imediatamente visado pelo direito, sobretudo no Estado Democrático, em que se espera que a pena traga algo de útil para a sociedade e ao próprio indivíduo. Tratase de um efeito colateral ao cumprimento da pena, principalmente na privativa de liberdade. A neutralização completa (mais radical), seja pela segregação definitiva, seja pela pena de morte, é o que pretende, em última análise, a prevenção especial negativa ${ }^{84}$.

\subsection{Prevenção especial positiva}

A pena, pela prevenção especial positiva, deveria ser pensada como uma espécie de remédio, como um bem $^{85}$ para o detento, mediante o conjunto das ideologias re (ressocialização, repersonalização, reeducação, reinserção, etc) ${ }^{86}$, o que, como veremos, é muitíssimo discutível e até mesmo perigoso, tendo referendado Estados de vertente totalitária.

O nascimento da pena como um remédio, ou medida profilática, se dá com a Escola Positiva italiana, que nega os pressupostos em que se baseava a Escola Clássica, pautada na responsabilidade individual da pessoa (vontade e livre-arbítrio) e na noção de pena como a retribuição de um mal por outro mal praticado. Assim, embora com algumas diferenciações, por diversos fundamentos, esse tão propalado livre arbítrio dos clássicos veio a ser questionado pelos teóricos do Positivismo jurídico italiano, especialmente Lombroso, Ferri e Garófalo.

Conforme anota Eduardo Reale Ferrari:

Partindo do fato de que o delinquente era fruto de uma concepção antropologicamente anormal, ou, quando muito, de má influência social, positivistas italianos defendiam a tese de que a punição se justificava apenas por responsabilidade social. Se por um lado a ausência do livre-arbítrio denotava falta de alternatividade por parte do indivíduo, por outro demonstrava incompatibilidade com o fim de retribuição; nascia a indagação de qual seria a justificativa para castigar o

\footnotetext{
${ }^{84}$ Fernando Falcón y Tella e Maria José Falcón y Tella. Fundamento e finalidade da sanção: existe um direito de castigar? Tradução de Claudia de Miranda Avena. São Paulo: RT, 2008, p. 219.

85 "No plano teórico este discurso parte do pressuposto de que a pena é um bem para quem a sofre, de caráter moral ou psicofísico. Em qualquer um dos casos oculta a natureza dolorosa da pena e chega mesmo a negar-lhe o próprio nome, substituído por sanções ou medidas" (Alejandro Alagia et al. Direito Penal Brasileiro: teoria geral do direito penal. Rio de Janeiro: Revan, 2003, p. 126).

${ }^{86}$ Alejandro Alagia et al. Direito Penal Brasileiro: Teoria Geral do Direito Penal. Rio de Janeiro: Revan, 2003, p. 116.
} 
delinqüiente, se o mesmo nunca tivera possibilidade de escolha. A resposta estava condicionada ao fato de que o fim de tal sanção não poderia ser o castigo, mas sim a inocuização ou correção do delinqüente, constituído, segundo Ferri, por fatores antropológicos, psíquicos e sociais, impondo-se a sanção por motivos relacionados a sua periculosidade e responsabilidade social ${ }^{87}$.

No que tange à prevenção especial, ela opera no momento da execução da pena.

Foi defendida, no século XIX, pela Escola Positiva da Itália e pela Escola da Alemanha, preconizada por Franz von Lizst, o qual - ainda que não pretendesse o referido desfecho do Nacional Socialismo - motivou diversas das atrocidades cometidas no Nazismo.

O delito deixa de se contemplar como um pecado, ao modo em que se fazia nas concepções absolutas e metafísicas anteriores. Agora, considera-se como uma enfermidade, com um substrato biológico e inclusive genético. $\mathrm{O}$ delinqüente é visto como alguém enfermo ao que há de tratar. É a idéia do tratamento, em face de seu precursor, a emenda moral ${ }^{88}$.

No Brasil, essas mesmas ideias frutificaram, podendo-se citar Raimundo Nina Rodrigues, o qual afirmava quanto ao negro que este seria rixoso, com uma potência sexual proeminente, muito dado à embriaguez, o que teria imediato reflexo na sua criminalidade. Segundo aponta a doutrina, ele chegou a sustentar a necessidade de haver quatro Códigos Penais para atender todas as raças e diversidades regionais no Brasil ${ }^{89}$.

Hoje, de certa forma, a doutrina tem sido muito reticente ao fim ressocializador da pena, haja vista a realidade penitenciária e a falência das penas privativas de liberdade.

A esse respeito, afirma Adauto Suannes:

Tais considerações são absolutamente incompatíveis com o pensamento da Criminologia contemporânea, que não mais vê na pena propósitos reeducacionais ou recuperadores, mas tão somente aquilo que, na prática, ela realmente é: uma retribuição por aquilo que se fez. Fez, pagou. Caso encerrado ${ }^{90}$.

\footnotetext{
${ }^{87}$ Eduardo Reale Ferrari. Medidas de segurança e direito penal no Estado Democrático de Direito. São Paulo: RT, 2001, p. 21-22.

${ }^{88}$ Fernando Falcón y Tella e Maria José Falcón y Tella. Fundamento e finalidade da sanção: existe um direito de castigar? Tradução de Claudia de Miranda Avena. São Paulo: RT, 2008, p. 17.

${ }^{89}$ A respeito de Raimundo Nina Rodrigues, vide: Sérgio Salomão Shecaira. Criminologia. São Paulo: RT, 2004, p. 106-107.

${ }^{90}$ Adauto Suannes. Os fundamentos éticos do devido processo penal. São Paulo: RT, 1999, p. 239.
} 
O efeito ressocializador da pena, portanto, em verdade, "não existe senão em discurso, que advém de um plano ideológico bastante distante da realidade" ${ }^{\prime 91}$.

Como ensina Heleno Cláudio Fragoso, sobretudo dentro dos códigos de cumprimento da pena privativa de liberdade, tal sistema constitui um mundo de regras tão à parte que é difícil vislumbrar alguma possibilidade de reeducação ou reinserção social daquele que tem que sofrer a pena privativa de liberdade e viver em uma instituição assim:

A prisão constitui um sistema de convivência anormal e violento, sujeito a pressões intoleráveis. As rebeliões são fatos comuns nas prisões e se devem ao ambiente autoritário e opressivo. O mau comportamento pode ser revelação do caráter e da dignidade do preso e o bom comportamento pode indicar apenas deformação da personalidade, adaptada a padrões carcerários (prisionização) ${ }^{92}$.

Ante todos esses motivos, qualquer pretensa teoria que atribua às penas privativas de liberdade a missão de ressocializar quem quer que seja, em um sistema tão desvirtuado como o prisional - ainda mais no caso do Brasil - se mostra fadada ao fracasso.

[...] ressocialização perante o quê? Ressocializar perante que conjunto normativo? Ressocializar perante que ideologia? Que normas? Que conjunto de valores? O conjunto de valores próprios de uma comunidade? O conjunto de valores defendido por um determinado pensamento político? O conjunto de valores propugnado por uma religião? Ou o conjunto de valores que se encontra encartado na legislação penal? Ressocializar seria condicionar, ou amoldar o homem condenado à legalidade penal? Mas qual legalidade penal? Amoldá-lo a toda legislação penal, inclusive à legislação extravagante? Mas submetê-lo, então, a uma lavagem cerebral e fazer inserir no seu espírito tudo aquilo que consta do Estatuto Penal e de toda a legislação penal? Ou apenas inserir no seu espírito a validade do valor, que ele desrespeitou pela crítica delituosa? [...] E mais uma pergunta se faz obrigatória: por que métodos e porque meios realizar esta propalada ressocialização social? É de se admitir que o delito é apenas uma oportunidade que o delinqüente dá para o Estado o recupere, pela utilização de métodos das ciências comportamentais, transformando a figura etérea, porque não existe na realidade científica, do 'criminoso', em outra realidade também etérea que é a do não criminoso $?^{93}$

Conforme acima exposto, o próprio conceito de "ressocialização", ou terapia social, mostra-se discutível, visto que, além de ser muito vago, não há qualquer constatação de que

\footnotetext{
${ }^{91}$ Víctor Gabriel Rodríguez. Fundamentos de Direito Penal Brasileiro. São Paulo: Atlas, 2011, p. 23.

${ }^{92}$ Heleno Cláudio Fragoso. Lições de direito penal: parte geral. Rio de Janeiro, Forense, 2003, pp. 360-361. A esse respeito, vide também: Erving Goffman. Manicômios, prisões e conventos. Tradução de Dante Moreira Leite. $5^{\text {a }}$ ed. São Paulo: Editora Perspectiva, 1996.

${ }^{93}$ Miguel Reale Júnior. Instituições de Direito Penal: parte geral. $3^{\text {a }}$ ed. Rio de Janeiro: Forense, 2009, p. 411412.
} 
realmente consiga lograr êxito. Outrossim, errôneo afirmar-se que todo e qualquer tipo de “criminoso" é um indivíduo que não esteja já devidamente socializado. Importante, nesse aspecto, aduzir acerca da problemática em se admitir que a reprimenda tenha um fim de recuperação do preso, transferindo-se a análise da necessidade da pena, frise-se desde já, pautada em critérios objetivos, como na ideia de retribuição pela conduta culpável praticada, conferindo-lhe, por isso, proporcionalidade ao seu cumprimento, para critérios um tanto quanto subjetivos.

Dessa forma, segundo Raúl Cervini:

Como preocupante sequiela natural da função que se atribui à pena, sua aplicação sai das mãos do juiz e passa às da equipe de tratamento, a qual, conforme as necessidades do tratamento ressocializador, determinará sua duração, extensão e tipo, de forma que "a pena tende a tornar-se indeterminada e se apaga a diferença em relação à medida de segurança, até quase ser suprimida ${ }^{94}$.

Como expõe Aury Lopes Júnior, começa a haver uma "desjurisdicionalização", na medida em que há uma tendência no sentido de os juízes da execução penal adotarem a posição de meros homologadores de laudos criminológicos, o que gera uma preocupante fundição da ciência jurídica com a psiquiátrica, podendo ocasionar, possivelmente, uma eventual "ditadura do modelo clínico"95.

Qualquer juízo que se faça quanto a uma eventual periculosidade do indivíduo mostrase, no mínimo, inseguro, pois, mesmo para estudiosos em ciências psicossociais, não há qualquer previsibilidade, ou mesmo dados plausíveis, para discorrer se o indivíduo irá ou não delinqüir futuramente ${ }^{96}$; o próprio conceito de ilícito é uma construção inerente a determinado nicho social, em uma determinada época e, portanto, mutável. Muito embora a criminalidade

\footnotetext{
${ }^{94}$ Raúl Cervini. Os processos de descriminalização. São Paulo: RT, 2002, p. 39.

${ }^{95}$ Aury Lopes Júnior. Introdução crítica ao processo penal: fundamentos da instrumentalidade garantista. $3^{\mathrm{a}}$ ed. Rio de Janeiro: Lumen Juris, 2005, p. 36, n. 88.

${ }^{96}$ Nas assertivas de Miguel Reale Júnior, o "juízo de periculosidade, repita-se, é absolutamente inseguro, basta atentar-se para a dicção do parágrafo único, ou seja, a constatação de condições pessoais que façam presumir que não voltará a delinqüir. As condições pessoais de ex-carcerário, sem a devida assistência, são manifestamente as piores, pois lesionado em sua personalidade pela subcultura carcerária, com a rejeição da sociedade. É evidente que as condições pessoais não podem ser as melhores. Os exames criminológicos, aliás, prendem-se às circunstâncias dos crimes para aferir se o condenado presumivelmente irá ou não delinqüir no futuro, o que se constitui em inadmissível bis in idem, e em manifesta inconstitucionalidade de julgar novamente o fato pelo ângulo da periculosidade não apreciada na sentença condenatória" (Miguel Reale Júnior. Instituições de Direito Penal. $3^{a}$ edição. Rio de Janeiro: Forense, 2009, p. 466).
} 
não seja um problema que se restrinja tão-somente a questões sócio-econômicas, mostra-se pertinente a seguinte indagação: "[...] como pretender ressocializar alguém que por razões conjunturais de desemprego, grave crise econômica, etc., comete um delito contra a propriedade, enquanto tais razões de desocupação e crise econômica continuam existindo?"97

Outra questão que agrava a situação do preso/sentenciado é o caráter altamente estigmatizante da condição de egresso. O indivíduo, na condição de ex-presidiário, dificilmente conseguirá encontrar um emprego digno, sendo induzido, conforme assevera Raúl Cervini, “à busca de um grupo em circunstâncias semelhantes à sua, e por isso costumam tomar parte de subculturas, nas quais terá normas, valores e formas de comportamento exigidos por outros membros desse grupo, mas geralmente condenados pela sociedade global. Isso tende a reafirmar seu comportamento desviante" ${ }^{, 98}$.

Nesse diapasão, conforme propõe Janaina Conceição Paschoal, quem, não obstante seja cética quanto ao caráter ressocializador da pena, estatui ser sempre desejável que se espere algo de bom da aplicação da pena, frise-se, não por meio de uma autoritária imposição de valores e de um tratamento à força, mas como forma de oferta a uma vida digna, sendo que esse dever não só corresponde ao Estado, mas a toda a sociedade, que deve fazer sua parte para dar mais dignidade às pessoas que por qualquer razão foram para o ilícito. ${ }^{99}$

\footnotetext{
${ }^{97}$ Raúl Cervini. Os processos de descriminalização. São Paulo: RT, 2002, p.42.

${ }^{98}$ Raúl Cervini. Os processos de descriminalização. São Paulo: RT, 2002, p.51. Nesse mesmo sentido, pondera Aury Lopes Júnior: "O sistema é autofágico. Ele se alimenta de si mesmo. Primeiro vem a exclusão (econômica, social, etc.), depois o sistema penal seleciona e etiqueta o excluído, fazendo com que ele ingresse no sistema penal. Uma vez cumprida a pena, solta-o, pior do que estava quando entrou. Solto, mas estigmatizado, volta às malhas do sistema, para mantê-lo vivo, pois o sistema penal precisa deste alimento para existir. É um círculo vicioso, que só aumenta a exclusão social e mantém a impunidade dos não excluídos (mas não menos delinqüentes)" (Aury Lopes Júnior. Introdução crítica ao processo penal: fundamentos da instrumentalidade garantista. $3^{a}$ ed., Rio de Janeiro: Editora Lumen Juris, 2005, p.18).

99 '“[...] muito se pode duvidar do caráter 'ressocializador' da pena; mas não se pode questionar a necessidade de criarem-se incentivos para que o egresso tenha condições mínimas de iniciar uma nova vida. É certo que o desemprego atinge a todos, parecendo, à primeira vista, injusto privilegiar os sujeitos que já passaram pelo sistema penitenciário. No entanto, mais que sofrer os efeitos do desemprego, o egresso sofre os efeitos do preconceito do Estado, que lhe veda participar de concursos e/ou assumir cargos públicos; e dos particulares que, vindo a saber de seus antecedentes, deixam de contratá-lo ou lhe dispensam [...]. O ideal, na verdade, seria reduzir o âmbito de aplicação das penas privativas de liberdade, de efeitos sabidamente deletérios; privilegiandose as penas alternativas. No entanto, enquanto houver pena de prisão; enquanto esse tipo de pena tiver larga aplicação, como ocorre no país, não é possível continuar a fingir que os presídios não existem, que as pessoas que se encontram dentro dos presídios não existem; e mais, que essas pessoas não irão sair. $\mathrm{O}$ ser humano tem a tendência a fugir da realidade, afastando de si tudo aquilo que lhe parece feio. Assim, bairros e cidades mobilizam para não receberem presídios ou unidades da Febem, quando deveriam buscar aproximação e, consequentemente, a integração que a pena privativa de liberdade, por si só, não é capaz de propiciar. A questão da segurança passa pela assunção de responsabilidade e, principalmente, pela admissão de que fingir que os
} 
Entre nós, Alamiro Velludo Salvador Netto entende relevante a finalidade da pena especial positiva, já que, a seu ver, “a prevenção especial positiva é, por certo, aquela que melhor se coaduna com o Estado social, dado que consegue, como nenhuma outra, entender a própria sociedade como criminógena, como propulsora do delito" ${ }^{100}$. Referido autor frisa que a prevenção especial positiva é um importante mecanismo de individualização da pena, devendo ser afastado, contudo, o caráter de segregação ou mesmo de tratamento, devendo ser uma oferta de oportunidades sociais, "de redimensionamento da maneira pela qual o agente se insere na sociedade capitalista" ${ }^{, 101}$.

A prevenção especial positiva visa emendar o infrator, por meio da sua reeducação ou reinserção social. O grande problema desses objetivos é "como identificar os riscos de reincidência futura que aconselham a neutralização na prisão? Cada indivíduo é um mundo. Não existem dois delinqüentes iguais" $" 102$.

As ideias de causas empíricas do delito (personalidade do delinqüente) preponderaram na Itália e França, através do movimento da "Defesa Social" (fascista italiano) e da "Nova Defesa Social" (francês), tendo acarretado a prática de muitas injustiças e diversas barbaridades. Também na Espanha os mesmos problemas se deram, podendo-se citar o ideário reabilitador da pena pensado por Montero Aroca.

Sobre a arbitrariedade e a violência no uso das punições, com vistas à emenda do delinqüente, mesmo em tempos mais recentes, há trabalhos interessantíssimos e inclusive produções cinematográficas a respeito, podendo-se citar o caso de Laranja Mecânica, de Anthony Burges, no qual "o personagem central se converte de vilão em vítima ao ser submetido a métodos de tratamento na prisão" ${ }^{\prime 103}$.

problemas não existem ou fingir que são apenas uma questão de Estado não ajuda a solucioná-los. Talvez a grande atribuição do Estado nessa nova forma de luta contra a violência seja assumir a sua insuficiência para enfrentar o problema; e ter coragem para suscitar o debate sobre o papel da sociedade nessa seara". (Janaina Conceição Paschoal. Segurança pública - poder e dever de todos. Das políticas de segurança pública às políticas públicas de segurança. São Paulo, Ilanud, 2002, p. 83-84).

${ }^{100}$ Alamiro Velludo Salvador Netto. Finalidades da pena, conceito material de delito e sistema penal integral. Tese de Doutoramento apresentada à Universidade de São Paulo, 2008, p. 214.

${ }^{101}$ Alamiro Velludo Salvador Netto. Finalidades da pena, conceito material de delito e sistema penal integral. Tese de Doutoramento apresentada à Universidade de São Paulo, 2008, p. 216.

${ }^{102}$ Fernando Falcón y Tella e Maria José Falcón y Tella. Fundamento e finalidade da sanção: existe um direito de castigar? Tradução de Claudia de Miranda Avena. São Paulo: RT, 2008, p. 219.

${ }^{103}$ “'O mais cru condutivismo e técnicas como as infligidas a Alec em Laranja mecânica ocorreram não apenas na ficção, mas igualmente na realidade, usando os prisioneiros como ratos de laboratório em experimentos com 


\subsubsection{Teoria eclética (ou unitária)}

A teoria eclética ou teoria unitária, que procura ver na pena não apenas uma, mas sim várias finalidades, é francamente vitoriosa na doutrina penal. Ao lado da retribuição, elencamse fins preventivos à pena, estatuindo-se tanto a prevenção de ordem geral (positiva e negativa) quanto de ordem especial (positiva e negativa).

A esse respeito, já discorria Basileu Garcia que "embora o Direito Penal não tenha conseguido eximir a pena da eiva de castigo, são inegáveis as suas múltiplas utilidades"104. Modernamente, tem-se entendido que a retribuição, a prevenção geral e a especial são distintos aspectos do fenômeno complexo da pena ${ }^{105}$.

Enfim, em suas versões moderadas, são teorias naturalmente conciliáveis (da retribuição e as da prevenção), servindo de um sistema de freios e contrapesos aos excessos possivelmente atribuíveis a uma e outra ${ }^{106}$. Em realidade, vemos, ultimamente, que o castigo, no direito penal, cumpre funções diversificadas dependendo da fase, podendo-se notar que "são os tribunais, os políticos e boa parte do grande público que continuam tratando o tema castigo de um modo moral, passional, invocando valores substantivos, adotando atitudes emocionais e implorando um castigo retributivo"107, ao passo que "as instituições penitenciárias atuais são geridas de um modo cada vez mais tecnocrático e instrumental, mais desapaixonado, em suma"108. Uns focam o caráter preventivo da pena (especialmente na ameaça da pena, no momento legislativo de cominação da pena) na intimidação (prevenção

drogas psicotrópicas, com substâncias como lítio ou, em casos mais extremos, submetendo-os a intervenções cirúrgicas para curar-lhes das tendências que lhes induziam a crimes como o estupro e a pederastia. Em Laranja mecânica o assalto dos baderneiros e a impotência de suas vítimas parecem exemplificar um encontro de irremediáveis contrários e, quando o chefe dos assaltantes violadores cai em mãos da polícia, o sistema começa a exercer sobre ele a violência não somente estrutural e administrativa, mas também terapêutica, plasmada no tratamento condutivista de seus impulsos criminais. O leitor assiste à brutal violência dos agressores desalmados e logo contempla a réplica assistencial do Estado neutral, cabendo o mesmo panorama de terror diante de ambos os tratamentos". (Fernando Falcón y Tella e Maria José Falcón y Tella. Fundamento e finalidade da sanção: existe um direito de castigar? Tradução de Claudia de Miranda Avena. São Paulo: RT, 2008, p. 96 e 97).

${ }^{104}$ Basileu Garcia. Instituições de direito penal. Volume I. Tomo II. 7. a ed. São Paulo: Saraiva, 2008, p. 05.

${ }^{105}$ Santiago Mir Puig. Direito penal: fundamentos e teoria do delito. Tradução de Cláudia Viana Garcia e José Carlos Nobre Porciúncula Neto. São Paulo: RT, 2007, p. 71.

${ }^{106}$ Fernando Falcón y Tella e Maria José Falcón y Tella. Fundamento e finalidade da sanção: existe um direito de castigar? Tradução de Claudia de Miranda Avena. São Paulo: RT, 2008, p. 54 e p. 174.

${ }^{107}$ Fernando Falcón y Tella e Maria José Falcón y Tella. Fundamento e finalidade da sanção: existe um direito de castigar? Tradução de Claudia de Miranda Avena. São Paulo: RT, 2008, p. 75.

${ }^{108}$ Fernando Falcón y Tella e Maria José Falcón y Tella. Fundamento e finalidade da sanção: existe um direito de castigar? Tradução de Claudia de Miranda Avena. São Paulo: RT, 2008, p. 75. 
geral negativa), restando outras funções para outros momentos da persecução (sentença: retribuição e prevenção geral positiva) e execução (prevenções especiais negativa e positiva).

Já outros, nessa fase, preferem trabalhar com a ideia de reafirmação do direito (prevenção geral positiva). Para Alamiro Velludo Salvador Netto:

\begin{abstract}
Quando da edição da norma de conduta (antijuridicidade) o legislador está pautado por finalidade preventiva-geral positiva, de modo a reafirmar o valor por trás da imperatividade jurídica. A pena deve estar justificada e limitada pelo conceito de merecimento, antevendo aspectos quantitativos e qualitativos que posteriormente sejam coordenados com os ideais de prevenção especial. Em segundo lugar, no tocante à norma de sanção (culpabilidade), a finalidade da pena é preventivo-especial positiva, admitindo-se, como elemento de correção, hipóteses de aplicabilidade da reprimenda sob o discurso de efeitos pragmáticos. Trata-se do ideal de necessidade da pena. Por fim, o conceito de merecimento e, particularmente, o de necessidade voltarão a ordenar as valorações político-criminais na determinação judicial da pena. ${ }^{109}$
\end{abstract}

Bem críticos quanto à junção das mais diversas teorias, Nilo Batista, entre nós, e Eugênio Raúl Zaffaroni, na Argentina, afirmam que "as combinações teóricas incoerentes, em matéria de pena, são muito mais autoritárias do que qualquer uma das teorias puras, pois somam as objeções de todas as que pretendem combinar e permitem escolher a pior decisão em cada caso. Não se trata de uma solução jurídico-penal, mas de uma entrega do direito penal à arbitrariedade e da conseqüente renúncia à sua função mais importante". ${ }^{110}$

\title{
2.1.4 Teorias abolicionistas e teoria agnóstica
}

As teorias abolicionistas não reconhecem qualquer legitimidade ao Direito Penal, sustentando que a pena estatal seja substituída por instrumentos pedagógicos, aplicados sem a intervenção do Estado.

\footnotetext{
${ }^{109}$ Alamiro Velludo Salvador Netto. Finalidades da pena, conceito material de delito e sistema penal integral. Tese de Doutoramento apresentada à Universidade de São Paulo, 2008, p. 217-218.

${ }^{110}$ Alejandro Alagia et al. Direito Penal Brasileiro: teoria geral do direito penal. Rio de Janeiro: Revan, 2003, p. 141.
} 
Com efeito, ao combaterem a apropriação do conflito pelo Estado, por entender faltar à Instituição conhecimento profundo das situações problemas, reconhecem como solução eficaz para a solução dos litígios a autogestão, no âmbito das próprias comunidades.

Denunciam a ilegitimidade dos sistemas penais, especialmente nos países latinoamericanos, em que as características fundamentais são a seletividade, a repressividade e a estigmatização. ${ }^{111}$

Concluindo que o sistema não se determina a punir todas as pessoas que cometam crimes, questionam como reconhecer legitimidade para a intervenção repressiva estatal.

Trabalhando com a ideia de dominação, e de igualdade apenas no âmbito formal, entendem que somente com a extinção do Estado, é que serão alcançadas a plena e total igualdade e liberdade.

$\mathrm{Na}$ sua versão mais radical, os abolicionistas entendem que a pena privativa de liberdade é a maior expressão da crueldade da repressão, e que não conseguem alcançar resultados eficazes na prevenção da criminalidade. "A pena não se presta a realizar os fins propostos, não se dirige a todos os autores de crimes e ainda importa em excessivo dispêndio de recursos sociais. Então, por que aplicá-la somente a alguns indivíduos?" 112

Os abolicionistas mais radicais estariam presos numa visão romântica, em que os indivíduos poderiam se autogerir, de forma que não seria necessária a existência do Direito Penal.

Os menos radicais não questionam a existência do Direito Penal, pretendendo sua construção como mínima intervenção e máxima garantia ao indivíduo.

Adepto do abolicionismo moderado, Eugênio Raúl Zaffaroni enxerga como única função do direito penal a imposição de limites à arbitrariedade estatal, não vendo mais qualquer objetivo na aplicação de pena.

\footnotetext{
${ }^{111}$ Fernando A. N. Galvão da Rocha. Direito Penal: curso Completo: parte geral. $2^{\mathrm{a}}$ ed. Belo Horizonte: Del Rey, 2007, p. 38.

${ }^{112}$ Fernando A. N. Galvão da Rocha. Direito Penal: curso completo: parte geral. $2^{\mathrm{a}}$ ed. Belo Horizonte: Del Rey, 2007, p. 51.
} 
Tobias Barreto, apesar de não ter se declarado adepto de uma teoria ou outra, em 1881, já denunciava a mania de tornar as coisas fáceis em difíceis, entendendo que seria inútil questionar a finalidade da pena, porque por mais que se questione, ela seria sacrificar ${ }^{113}$. E procurar o fundamento jurídico da pena seria o mesmo que procurar o fundamento da guerra. $^{114}$

Traçando um paralelo entre os dois autores, Salo de Carvalho dispõe que:

Entendida como fenômeno da política, a pena, assim como a guerra, não encontra sustentação no direito, pelo contrário, simboliza a própria negação do jurídico. Ambas (pena e guerra) se constituem através da potencialização da violência e da imposição incontrolada de dor e sofrimento. O caráter incontrolável, desmesurado, desproporcional e desregulado da política reivindica, no âmbito das sociedades democráticas, limite. ${ }^{115}$

Salo de Carvalho entende que a Constituição de 1988 assumiu a teoria agnóstica da pena, na medida em que seus princípios referem-se à forma e limite de punição, e não a qualquer tipo de justificação.

A cadeia principiológica definida pela Constituição, ao optar pela exclusiva fixação de limites à forma (meios), supera as finalidades históricas das penas, concebendo política criminal ciente dos danos causados. Outrossim, reconhece a tendência natural do poder punitivo em extravasar os limites da legalidade, preocupando-se,

113 "Podem phrases theoreticas encobrir verdadeira feição da cousa, mas no fundo o que resta é o fato incontestavel de que punir é sacrificar, sacrificar, em todo ou em parte, o indivíduo ao bem da communhão social, sacrifício mais ou menos cruel, conforme o gráo de civilisação deste ou daquelle povo, nesta ou n'aquella época dada, mas sacrificio necessario, que, se por um lado não se accommoda á rigorosa medida juridica, por outro lado também não póde ser abolido por effeito de um sentimentalismo pretendido humanitario, que não raras vezes quer ver extinctas por amor da humanidade cousas, sem as quaes a humanidade não poderia talvez existir". (Tobias Barreto de Meneses. Fundamentos do Direito de Punir. Estudos de Direito. História do Direito Brasileiro. Vol. 5. Brasília: Senado Federal, 2004. p. 171).

114 Tobias Barreto de Meneses. Fundamentos do Direito de Punir. Estudos de Direito. História do Direito Brasileiro. Vol. 5. Brasília: Senado Federal, 2004, p. 178.

115 Salo de Carvalho. Garantismo e direito de punir: teoria agnóstica da pena. Disponível em: $<$ http://www.grupos.com.br/group/cienciascriminais8/Messages.html?action=download\&year=10\&month=6\&id $\equiv 1276553255444592 \&$ attach=Garantismo+e+direito+de+punir+SALO+DE+CARVALHO.doc $>$ Acesso em: 15 dez. 2013. 
essencialmente, em reduzir ao máximo as hipóteses de transbordamento punitivo. Não por outro motivo se pode verificar na Constituição perspectiva agnóstica. ${ }^{116}$

\subsection{A contribuição de Luigi Ferrajoli da razão (finalidade preventiva) e do como punir (de modo retributivo)}

Apesar de negar (e ser taxativamente contra) uma finalidade apenas retributiva (que seria um fim em si mesmo), Luigi Ferrajoli não desconsidera que o direito penal, como um todo, tem e deve mesmo ostentar um caráter retributivo. Retributividade que lhe confere proporcionalidade; ainda mais quando entra em jogo a questão consistente em como se punir adequadamente, já que é justamente a retribuição que confere razoabilidade e sensatez entre a pena cominada e a lesão efetivamente causada.

Luigi Ferrajoli chega até mesmo a falar em princípio retributivo do direito penal, tal a sua importância. $\mathrm{O}$ autor diz que quem fala em finalidade retributiva da pena, na verdade, faz uma confusão com o caráter retributivo do direito penal, que está sempre presente. Confundese o porquê se pune (que tem em vista o utilitarismo, a prevenção) com o como se pune (a forma retributiva). Assim coloca o autor:

Referida confusão, por sua vez, depende da não distinção entre razão legal e a razão judicial da pena. Usando a linguagem com a qual decompus e reformulei o problema da legitimação do direito penal, podemos dizer que trocou-se a questão do 'porquê punir?", atinente à legitimidade externa da pena, com a questão do 'como punir?', que, ao contrário, diz respeito à legitimação interna, admitindo, assim, como resposta, precisamente o princípio retributivo, isto é, a primeira garantia do direito penal em razão da qual a condição necessária da pena é, antes de mais nada, o cometimento de um delito ${ }^{117}$.

\footnotetext{
${ }^{116}$ Salo de Carvalho. Antimanual de criminologia. $5^{\text {a }}$ ed. São Paulo: Saraiva, 2013, p. 261.

${ }^{117}$ Luigi Ferrajoli. Direito e razão: teoria do garantismo penal. Tradução de Ana Paula Zomer et al. São Paulo: RT, 2002, p. 207. Entre nós, na Universidade de São Paulo, Adjair de Andrade Cintra defendeu que a pena tem função retributiva e finalidade preventiva, posição muito parecida com a de Luigi Ferrajoli. A esse respeito, consultar Adjair de Andrade Cintra. Prescrição penal e finalidades da pena. Dissertação de Mestrado apresentada à Universidade de São Paulo, 2007, p. 43.
} 
Para Luigi Ferrajoli, então, conforme suas próprias palavras: “o utilitarismo, não fosse pelo fato de que exclui as penas sociamente inúteis, é, resumindo, o pressuposto necessário de toda e qualquer doutrina penal sobre os limites do poder punitivo estatal"118.

$\mathrm{O}$ autor pontua que dependendo do tipo de utilitarismo, tanto ele pode fundar um sistema de direito penal máximo quanto um direito penal mínimo. Assim, por exemplo, se nele houver uma finalidade à máxima utilidade possível garantida à maioria formada pelos não desviantes, isso pode fundamentar um direito penal máximo, já que as penas tenderão a ser mais rígidas e exemplares, pois só se foca na utilidade e bem estar das pessoas que não cometeram o crime. Contudo, se o utilitarismo for interpretado em prol - além do bem estar da maioria - também do mínimo sofrimento necessário à minoria formada pelos desviantes, já este tipo de utilitarismo pode fundar um sistema penal mínimo. ${ }^{119}$

A retribuição, nesses termos, fundamenta uma filosofia de política liberal, que vê na proporcionalidade um limite como garantia ao indivíduo, entre pena e delito praticado.

Tem, dessa forma, servido de fundamentação e combate a ditas teorias utilitárias que fundamentaram as arbitrariedades que cometera a Alemanha, em nome dos excessos da prevenção $^{120}$. No mesmo sentido manifesta-se Helena Regina Lobo da Costa quando diz que:

no que se refere à retribuição, malgrado não seja mais aceita isoladamente como fim da pena, há aspectos fundamentais trazidos por essa vertente ao direito penal que devem ser mencionados. Assim, a ideia de que a pena configura um mal aplicável em decorrência de outro mal (crime) é essencial para a imposição de limites às sanções, por meio da concepção de que a pena não pode ultrapassar a medida da culpabilidade. $^{121}$

\footnotetext{
${ }^{118}$ Luigi Ferrajoli. Direito e razão: teoria do garantismo penal. Tradução de Ana Paula Zomer et al. São Paulo: RT, 2002, p. 209.

119 "Se, realmente, a finalidade a ser alcançada contra a repetição de futuros delitos for somente aquela da máxima segurança social, tal fato, por si só, serviria para legitimar, aprioristicamente, os meios máximos, ou seja, as penas mais severas, inclusive aquela de morte, bem como os procedimentos mais antigarantistas, compreendidas a tortura e as medidas policiais mais pervasivas e não liberais. Obviamente, o utilitarismo, se concebido neste sentido, não é garantia, de modo algum, diante do arbítrio potestativo, ao passo que se a finalidade é, também, aquela do mínimo sofrimento necessário na prevenção de males futuros, justificar-se-ão somente os meios mínimos, vale dizer, o mínimo das proibições, o mínimo das penas..." (Luigi Ferrajoli. Direito e razão: teoria do garantismo penal. Tradução de Ana Paula Zomer et al. São Paulo: RT, 2002, p. 211).

${ }^{120}$ Santiago Mir Puig. Direito penal: fundamentos e teoria do delito. Tradutores: Cláudia Viana Garcia e José Carlos Nobre Porciúncula Neto. São Paulo: RT, 2007, p. 60.

${ }^{121}$ Helena Regina Lobo da Costa. Direito Penal Econômico e Direito Administrativo Sancionador: ne bis in idem como medida de política sancionadora integrada. Tese de Livre-Docência apresentada à Universidade de São Paulo, 2013, p. 149.
} 


\subsection{Finalidades da pena e sua individualização no ordenamento jurídico brasileiro}

Inegável que da leitura do artigo 59, do Código Penal, são fins da pena, no ordenamento jurídico brasileiro, tanto a retribuição quanto a prevenção do delito. Da análise da lei, é "impossível dizer que a lei nacional determine que a finalidade da pena projete-se apenas para o futuro. A finalidade da lei é também o castigo" ${ }^{\prime 122}$.

De fato, consta da redação do artigo 59, do Código Penal, que “o juiz, atendendo à culpabilidade, aos antecedentes, à conduta social, à personalidade do agente, aos motivos, às circunstâncias e consequências do crime, bem como ao comportamento da vítima, estabelecerá, conforme seja necessário e suficiente para reprovação e prevenção do crime".

O uso dos termos reprovação e prevenção deixam nítido que esses são os dois desideratos da lei, tanto retributivo quanto preventivo.

Não obstante o desejo da lei, ao estipular a análise de circunstâncias tão subjetivas dos acusados, seja alcançar o duplo objetivo de retribuir e prevenir, os estudos do conceito de conduta social e personalidade, na doutrina (abaixo), e a verificação de seu entendimento, em julgados dos Tribunais Pátrios (Capítulo $3^{\circ}$ ) revelaram o quanto, ainda, tal objetivo se encontra desorientado, afastado de qualquer baliza, e permeado por excessiva carga moralista, punindose mais o ser pelo o que é do que efetivamente fez.

Sabe-se que o objetivo da individualização da pena é encontrar a justa e adequada sanção penal ao indivíduo condenado, de forma que sua reprimenda seja um ato único e distinto de eventuais outros infratores.

Sua finalidade e importância, nas palavras de Guilherme de Souza Nucci, “é a fuga da padronização da pena, da "mecanizada" ou "computadorizada" aplicação da sanção penal, que prescinda da figura do juiz, como ser pensante, adotando-se em seu lugar qualquer programa ou método que leve à pena pré-estabelecida, segundo um modelo unificado, empobrecido e, sem dúvida, injusto."123

\footnotetext{
${ }^{122}$ Víctor Gabriel Rodríguez. Fundamentos de Direito Penal Brasileiro. São Paulo: Atlas, 2011, p. 25.

${ }^{123}$ Guilherme de Souza Nucci. Individualização da Pena. $2^{\text {a }}$ ed. São Paulo: RT, 2007, p. 30.
} 
A fixação da pena é regulada por regras e princípios constitucionais previstos na Constituição Federal, no Código Penal e no Código de Processo Penal. A título de exemplo, destacamos os seguintes dispositivos: Artigos 5 incisos XLV, XLVI, XLVII da Constituição Federal, 59 do Código Penal e 387 do Código de Processo Penal.

Não obstante a vigência de regras constitucionais, no artigo 59 do Código Penal, é que estão elencados os critérios balizadores da fixação da pena na primeira fase do procedimento trifásico.

As circunstâncias judiciais do artigo 59 do Código Penal, além de nortearem a fixação da pena-base, também são utilizadas para o estabelecimento de quais penas serão aplicadas, dentre as cominadas; para a fixação do regime de cumprimento de pena; e para a determinação de eventual substituição da pena privativa de liberdade.

Não só no momento de aplicação da pena e da fixação de regime de cumprimento de pena se fazem presentes as circunstâncias pessoais do artigo 59, mas também para a suspensão condicional da pena (artigo 77, II), para a concessão de livramento condicional (artigo 83, I e parágrafo único), bem como para os fins de aplicação dos benefícios da Lei 9.099/95, dentre outros.

Dentre as circunstâncias judiciais pessoais, constantes do artigo 59, as que serão objeto do presente trabalho são a conduta social e a personalidade.

Apesar de a circunstância judicial dos antecedentes não ser objeto do trabalho, será tratada, de forma indireta, uma vez que, como será demonstrado pela apresentação do estudo dos julgados dos Tribunais pátrios, antes da Súmula 444 do Superior Tribunal de Justiça, havia diversos e polêmicos posicionamentos acerca do que comporiam os antecedentes criminais, sendo certo que mesmo após a edição desta Súmula, os apontamentos que não podem ser considerados, tecnicamente, como antecedentes, são indevidamente valorados como, por exemplo, má conduta social ou personalidade desajustada ou voltada ao crime.

Portanto, ainda que existente o entendimento sumulado do Superior Tribunal de Justiça, deve-se ponderar não se tratar de súmula vinculante e que, infelizmente, muitos juízes de primeira instância simplesmente não a aplicam. 
O dissenso não pertence somente à jurisprudência, existindo igualmente na doutrina, conforme se depreende dos trechos que seguem.

Os antecedentes não dizem respeito à "folha penal", e seu conceito é bem mais amplo, pois como assinala Nilo Batista "o exame do passado judicial do réu é apenas uma fração". Por antecedentes deve-se entender a forma de vida em uma visão abrangente, examinando-se o seu meio de sustento, a sua dedicação a tarefas honestas, a assunção de responsabilidades familiares. Em suma, a lição de Hungria é exata: 'Ao juiz compete extrair-lhe a conta corrente, para ver se há saldo credor ou devedor' 124 .

Ao serem analisados os antecedentes, serão enfocados aqueles judiciais, que não se acham contemplados pelo Código, como causas legais de agravamento ou atenuação da pena. Serão assim considerados processos paralisados por superveniente extinção da punibilidade: inquéritos arquivados, condenações não transitadas em julgado, processos em curso, absolvições por falta de prova. De grande valia averiguar que se trata de criminoso habitual ou episódico, quando o delito pelo qual estiver sendo julgado for um ato isolado em sua vida precedente. ${ }^{125}$

Na hipótese de prescrição da reincidência, a condenação que caducou para esse fim continua válida para gerar maus antecedentes. É claro que, com o passar do tempo, os processos e condenações anteriores vão perdendo a influência sobre a pena de futuros crimes, mas, de acordo com as peculiaridades de cada caso concreto, não se podendo falar em prazo fixo de prescrição. ${ }^{126}$

Mais grave é atestar que aquilo que sequer poderia se configurar antecedentes, ainda que na sua mais ampla forma do termo, pode ser indevidamente considerado na qualidade de conduta social.

Assim, quando o fato delituoso for levado ao tribunal, os estragos que ele já provocara anteriormente, sem ter havido julgamento criminal - se houvesse, certamente estaria essa situação incluída no contexto de antecedentes ou mesmo da reincidência - devem ser levados em conta como conduta social, a fim de buscar a pena-justa. O relacionamento social do indivíduo é fruto e função do seu caráter. ${ }^{127}$

Independentemente do conceito que se atribua aos antecedentes, bem como de em qual circunstância judicial será valorado aquilo que não puder, tecnicamente, ser considerado como

${ }^{124}$ Miguel Reale Júnior. Instituições de Direito Penal: parte geral. $3^{a}$ Ed., Rio de Janeiro: Editora Forense, 2009 p. 407.

${ }^{125}$ Paulo José da Costa Jr. Curso de Direito Penal. São Paulo: Saraiva, 2009, p. 195.

${ }^{126}$ Fernando Capez. Curso de Direito Penal: parte geral. Volume 1. São Paulo: Saraiva, 2002, p. 390.

${ }^{127}$ Guilherme de Souza Nucci. Individualização da Pena. $2^{\mathrm{a}}$ ed. São Paulo: RT, 2007, p. 183-184. 
tal, tais inscrições rotulam as pessoas, estampando-as com as duras marcas da estigmatização, o que acarreta um pré-julgamento, em afronta ao princípio constitucional da presunção de inocência.

O ser humano não consegue se desvincular dos seus julgamentos, e lançar sobre o outro olhar neutro, que transcenda qualquer tipo de valoração. Só se consegue valorar a vida dos outros, sob a ótica de quem observa. Esta questão será enfrentada no Capítulo $4^{\circ}$.

Uma pergunta desempenhou um grande papel na gênese desta obra [Tipos Psicológicos]: em que eu me distinguia de Freud? E de Adler? Que diferenças havia entre as nossas concepções? Refletindo sobre isso deparei com o problema dos tipos. É o tipo que precisa e limita de antemão os julgamentos do homem. O livro sobre os tipos psicológicos trata principalmente do confronto do indivíduo com o mundo, das suas relações com os homens e coisas. Nele descrevo os diferentes aspectos da consciência, as possibilidades de sua atitude em relação ao mundo. [...] Meu livro sobre os tipos psicológicos conclui que todo julgamento de um homem é limitado pelo seu tipo de personalidade e que toda maneira de ver é relativa. ${ }^{128}$

Conforme já ponderado no primeiro Capítulo, não há como negar o valor da interferência do observador sobre o observado. Com razão David de Paiva Costa Tangerino quando dispõe que:

Bem verdade que há muito se abandonou, ao menos em sede das ciências humanas, o hoje referido como "mito da neutralidade científica", que poderia ser sintetizado na crença de que a aplicação rigorosa dos métodos científicos levaria a conclusões neutras, válidas universalmente, isto é, invariáveis conforme o pesquisador que a executa. O abandono deu-se em face da incontornável contestação de que o pesquisador terá sido talhado em um determinado momento histórico, inserido em uma dada condição social, marcado por sua história de vida de tal sorte que sua mundividência marcará sua condução de vida, abrangida inclusive a produção científica. ${ }^{129}$

Cada um vive em seu quadrado, sendo a intersecção dos quadrados uma proeza ímpar, daí a dificuldade de enxergar o outro com olhos completamente isentos.

A valoração de tais máculas na vida do réu, seja na qualidade de antecedentes, seja na de conduta social ou personalidade, é algo preocupante, na medida em que o ser humano não tem preparo suficiente para considerar a vida alheia, sem projetar seus conteúdos internos, fato que impossibilitaria um julgamento neutro.

\footnotetext{
${ }^{128}$ Carl Gustav Jung. Memórias, Sonhos, Reflexões. Tradução de Dora Ferreira da Silva. Rio de Janeiro: Nova Fronteira, 2006, p. 246-247.

${ }^{129}$ Davi de Paiva Costa Tangerino. Culpabilidade. Rio de Janeiro: Elsevier, 2011, p. 10.
} 
De nada serve um sistema constitucional de garantias para o processo penal, se descuidarmos do "juiz", não como figura jurídico-processual (actum trium personarum - Bulgaro), mas como "sujeito". Não se navega no contravento sem saber usar o vento. Isso é primário. Como bem aponta o autor, existe farta possibilidade de que o julgador termine por incutir (ou sorrateiramente incluir, é óbvio), em meio à maquinagem argumentativa jurídica, aspectos única e exclusivamente de cunho pessoal, de descarrego psíquico. Por elementar, não há como evitar isso, mas é fundamental desvelar e assumir a subjetividade. Só através da assunção desse risco é que poderemos construir mecanismos mais eficazes de redução de danos, até porque, a eliminação da subjetividade não é possível e tampouco desejada. Um conceito de "garantias" processuais somente pode ser concebido a partir da assunção dos riscos, ou seja, a falta sempre será constitutiva. ${ }^{130}$

Alvino Augusto de Sá relata que toda relação entre duas pessoas é permeada por projeções de conteúdos internos, e que certas características da pessoa em exame podem ser salientadas ou minimizadas, a depender da reação pessoal do examinador, tendo em vista sua história, sua identificação com elas, enfim, seu conteúdo interno.

Para a psicologia de orientação psicodinâmica, a relação entre duas pessoas ou entre uma pessoa e um objeto por ela percebido e analisado é sempre um caminho por onde passam projeções dos conteúdos internos. Consequentemente, a "valorização" (avaliação) que uma pessoa faz da outra ou do objeto é permeada pelos conteúdos internos de quem avalia. Trata-se de um processo normal de intercâmbio sujeitoambiente, inevitável na relação entre examinador e examinando (pessoa avaliada), bem como entre o examinador e o crime ("objeto" avaliado) praticado. Certas características do examinando podem ser realçadas ou minimizadas pelo examinador, dependendo de sua reação pessoal diante delas e diante do tipo de crime cometido, objeto de análise, ou da própria sintonia ou identificação dele com esse crime etc. Por conseguinte, a relação reflexiva existe sempre ${ }^{131}$.

Ainda com referência a essa relação reflexiva, importante consignar que o problema não está com o fenômeno da reflexividade em si, mas sim com a possibilidade de o examinador não ter consciência deste processo, algo que, aliás, é uma condição difícil de alcançar até para um clínico, exigindo muita experiência para isso.

O que pode não existir sempre é a atividade reflexiva, que se interpretaria aqui como sendo uma atividade consciente, na qual o sujeito se posiciona par a par (e não hierarquicamente ou estranhamente) com a pessoa e o objeto, consegue ficar atento para as identificações suas com a pessoa e o objeto, distinguindo inclusive aquelas

\footnotetext{
${ }^{130}$ Prefácio de Aury Lopes Junior in Gabriel Antinolfi Divan. Decisão judicial nos crimes sexuais: o julgador e o réu interior. Porto Alegre: Livraria do Advogado Editora, 2010.

131 Alvino Augusto de Sá. Criminologia clínica e execução penal: proposta de um modelo de terceira geração. São Paulo: RT, 2011, p. 107-108.
} 
identificações que são verdadeiras daquelas que são unicamente fruto de projeções, transferências e contratransferências. Esta é uma qualidade muito difícil na prática clínica, mas que se espera seja desenvolvida com a experiência ${ }^{132}$.

Se até a um clínico, um profissional especializado em psicologia e psiquiatria, somente a experiência poderia trazer a consciência real dos processos que envolvem um atendimento pessoal (a troca constante de seus conteúdos internos), que dizer da relação entre juiz e réu? ${ }^{133}$.

Alvino Augusto de Sá alerta que este tipo de relação, muito embora seja mais afeta ao que denomina setting analítico, ocorre nas relações diárias, entre as pessoas.

Tendo-se discorrido sobre os termos acima, convém agora deixar o contexto analítico e refletir sobre eles na vida cotidiana, na vida social, institucional. Se a transferência não é exclusiva do paciente, se a contratransferência não é exclusiva do paciente, se a contratransferência não é exclusiva do analista, é de se acrescentar agora que ambas não são exclusivas do setting analítico. Transferência e contratransferência, enquanto fenômenos da dinâmica psíquica, são comumente referidas ao setting analítico, pois é aí que elas foram identificadas, estudadas e aproveitadas na prática. É aí que elas acontecem com mais intensidade, sobretudo a transferência, em função do ambiente de neutralidade criado por parte do analista ou terapeuta. Entretanto, elas ocorrem na vida diária, nas relações pessoais, de grupo, sociais e institucionais, nas relações entre dirigentes e dirigidos, líderes e liderados, patrões e empregados, exploradores e explorados, examinador e examinando, professor e aluno. ${ }^{134}$

A existência dos processos internos elencados por Alvino Augusto de Sá, que ocorrem com qualquer ser humano, nos seus mais variados relacionamentos, inspira demasiada preocupação, quando referidos à análise da conduta social e personalidade do agente, pois abrem justamente uma porta muito ampla para tais trocas de conteúdos entre os julgadores e seus réus. Conteúdos estes perigosos, pois passam despercebidos até para quem tem experiência clínica, que dirá para um juiz, que, a princípio, não tem qualquer conhecimento sobre o assunto.

Importante frisar que nosso trabalho não se presta a tecer qualquer juízo de valor sobre as pessoas dos magistrados e convidamos o leitor a fazer o mesmo. Estamos

\footnotetext{
${ }^{132}$ Alvino Augusto de Sá. Criminologia clínica e execução penal: proposta de um modelo de terceira geração. São Paulo: RT, 2011, p. 107/108.

133 "É bom que se entenda que reflexividade está sendo tomada aqui no sentido de um fluxo de interações permeadas de projeções, transferências e contratransferências, ou seja, um fenômeno psíquico pelo qual um protagonista se reflete no outro." (Alvino Augusto de Sá. Criminologia clínica e execução penal: proposta de um modelo de terceira geração. São Paulo: RT, 2011 p. 107).

${ }^{134}$ Alvino Augusto de Sá. Criminologia clínica e execução penal: proposta de um modelo de terceira geração. São Paulo: RT, 2011, p. 104-105.
} 
interessados exclusivamente em apontar o quanto o exercício da jurisdição acaba se pautando também por aspectos metajurídicos, de natureza psicológica, incidentes no curso da atuação de cada julgador - e tão alheios à sua vontade quanto mais inconsciente ele estiver deles. ${ }^{135}$

Também tratando do processo de projeção havido entre julgador e acusado ou julgador e vítima se manifestou Alexandre Morais da Rosa:

\begin{abstract}
Quem julga pode ser julgado, no próprio ato, a saber, na mesma sentença em que julga o outro, pode acontecer um processo de projeção, quer com a vítima, quer com o acusado. Enfim, das armadilhas da subjetividade, não se escapa. Afinal, ainda se é humano, ou se aparenta ser. O orgulhoso sujeito da modernidade é ficção que embala os sonhos dogmáticos de gente que perambula nos foros ouvindo a voz do legislador ou mesmo colocando a orelha no Código para ver o que a lei lhe diz. Gente como esta precisa de ajuda, porque, de fato, o quadro instaurado é de ordem diversa. E disto se faz as decisões judiciais. No enleio entre texto, norma, sujeitos e indivíduos, no crime, uma sentença é produzida. Na fusão de horizontes (Gadamer) que a decisão judicial é o sintoma, não se pode dizer tudo o que foi condicionante. Pode-se, quem sabe, abrir uma clareira, mas ela, dizia Heidegger, possui uma floresta que lhe dá sentido. ${ }^{136}$
\end{abstract}

Com efeito, permitir ao juiz, que não é conhecedor destes mecanismos psicológicos internos de cada um, e, portanto, não sabe como guardar a devida distância, a fim de não se identificar com a situação, ter conhecimento da vida pregressa do réu, de como ele se comporta em sociedade, ou mesmo, como é sua personalidade, se é que se pode realmente afirmar da real possibilidade disso, é permitir a indevida manifestação da arbitrariedade no julgamento. Arbitrariedade há que se dizer desconhecida do próprio julgador, pois é canal da transmissão invisível de tais conteúdos pessoais que, certamente, se imiscuirão no julgamento.

Por ora, entende-se que antes de destrinçar os caminhos internos das decisões judiciais, tema a que dedicamos o Capítulo $4^{\circ}$ deste trabalho, julgamos importante relatar como a doutrina, e na sequência, a jurisprudência, conceituam e compreendem "conduta social" e "personalidade", para fins de fixação da pena acima do mínimo legal.

\footnotetext{
135 Antoin Abou Khalil. A personalidade do juiz e a condução do processo. São Paulo: Antoin Abou Khalil, 2011, p. 124.

${ }^{136}$ Apresentação de Alexandre Morais da Rosa in Gabriel Antinolfi Divan. Decisão judicial nos crimes sexuais: o julgador e o réu interior. Porto Alegre: Livraria do Advogado Editora, 2010, p.13.
} 


\subsection{Conduta social}

Conceituar conduta social é complexo. Critério altamente subjetivo. Pode-se dizer da conduta que o indivíduo tem na sociedade (escola, trabalho, família, cultos). Pode-se dizer da conduta de liberdade de escolha de crença, de liberdade de orientação sexual, de escolha política.

O leque de possibilidades é enorme; assim como também são as formas de julgamento sobre o que seja bom ou ruim.

Existem, por exemplo, pessoas que gozam de ótima reputação social, sendo irreparáveis em seus trabalhos, escolas, igrejas (leia-se: cultos em geral), na vizinhança, mas dentro de casa são verdadeiros carrascos, espancadores de familiares. Outras, no entanto, que gozam de péssima reputação social, mas são pais zelosos, maridos/esposas primorosos.

Há ainda aqueles que são pais carinhosos, mas completamente descuidados com alguns deveres básicos, por assim dizer, fumam na frente dos filhos, não os alimentam adequadamente (maus hábitos alimentares), são relapsos com os deveres de escola.

Há pessoas que caracterizam uma mãe ruim a que não força o filho a se alimentar, respeitando, portanto, o seu apetite. De forma totalmente contrária, há outras pessoas que julgam más mães as que não respeitam seus filhos, forçando-os a se alimentarem quando não querem. É complicado mensurar.

O que dizer ainda daqueles indivíduos que, sendo casados, ainda assim, a fim de desafogar o seu furor lascivo, flertam com outras pessoas; ou dos que ganham a vida com a prostituição. Que conduta social pode se aferir daqueles que passam noites na esbórnia, acompanhado de todo tipo de pessoa, muitas vezes bebendo, usando drogas, fazendo sexo sem segurança, mas que são filhos respeitosos, arrimo de família, trabalhadores.

Como perquirir conduta social desviada ou qualquer outra forma pejorativa de julgamento de alguém que, não obstante exerça função respeitada no trabalho, tenha como lazer freqüentar casas de swing, clubes noturnos e jogatinas. 
Como estimar a conduta social de uma mãe de santo, dona de terreiro de umbanda que, para os frequientadores, é vista como uma santa; e para os de fora é temida e considerada uma "macumbeira".

Como julgar os movimentos jovens de rock, conhecidos como punks, darks, góticos e afins, como conduta social desviada, voltada ao crime. E o que se dirá dos homossexuais.

Os exemplos são infinitos, tanto quanto infinitas são as possibilidades de conclusões acerca do que seja e esteja englobado no conceito de conduta social, assim como as mais diversas conclusões sobre condutas sociais positivas ou negativas, influenciadas por todo tipo de carga valorativa, com subjetivismos, preconceitos, falta de respeito e intolerância às diferenças, além do interesse de imposição do que se entende certo.

Podem parecer exemplos alheios ao Direito Penal, mas, na medida em que o legislador abre ao juiz uma porta tão larga como a da conduta social, para fins de dosar a pena-base acima do mínimo legal; e uma vez que somente a conduta social, negativamente orientada é tomada em consideração, é urgente o aprofundamento do estudo para trazer luz às questões acima reportadas.

A análise da jurisprudência pátria, conforme se verificará do Capítulo $3^{\circ}$, demonstra que a permanência desta circunstância é somente para prejudicar, pois não se encontrou um único caso em que, em função de ótima conduta social, a pena-base tenha sido aplicada abaixo do mínimo legal. Fato que demonstra a reprimenda dos indivíduos pelo que são, mas do que pelo o que fazem.

A permanência desta circunstância judicial, que não guarda qualquer relação com o fato em si, somente será palco de julgamentos preconceituosos, baseados em subjetivismos, nos termos dos entendimentos dos doutrinadores abaixo.

As pessoas pobres, pelo ambiente em que vivem, estão mais sujeitas a envolver-se na ação policial, aparecendo em processos. ${ }^{137}$

É imprescindível, no entanto, haver uma análise do meio e das condições onde o agente se formou e vive, pois o bem-nascido que tende ao crime deve ser mais

${ }^{137}$ Heleno Cláudio Fragoso. Lições de Direito Penal: parte geral. Rio de Janeiro: Forense, 2003, p. 407. 
severamente apenado do que o miserável que tenha praticado uma infração penal para garantir sua sobrevivência. ${ }^{138}$

Abaixo, segue o entendimento de vários doutrinadores acerca do conceito conduta social.

Dos posicionamentos amealhados, em grande parte fica clara a redução da análise da conduta social à vida pregressa do condenado e à sua relação na família e trabalho, como um resquício do que era englobado, a título de antecedentes, por ocasião da análise do antigo artigo 42 do Código Penal, anteriormente à reforma de 1984.

Com efeito, Nelson Hungria, quando tratou dos antecedentes previstos no artigo 42, como sendo todos os fatos ou episódios da vita ante acta do réu, que fossem importantes na avaliação subjetiva do crime, além de mencionar os antecedentes judiciais, que compreendiam também os de natureza cível ou comercial, falou da necessária pesquisa da vida pregressa do réu, nos seguintes termos:

Por outro lado, deve ser pesquisado, na medida do possível, o sistema de vida pregressa do réu, quer do ponto de vista individual, quer do ponto vista familiar ou social. Deve ser o réu identificado, notadamente, no seu ambiente social, no clima de moralidade em que se fez homem, nas suas boas ou más condições de educação. Cumpre indagar se o crime praticado é um episódio acidental de sua vida, ou se é um consectário de sua propensão ou habitual orientação para o mal e a indisciplina. Embora sem antecedentes judiciários, um indivíduo pode ter uma vida pontilhada de deslizes, de pequeninas infâmias ou faltas morais, que revelam nêle um elemento mal-ajustado à ordem social. Para que se reconheçam bons antecedentes ao réu, não basta que êle seja sceleris purus: é também necessário que seja integer vitae. Pode acontecer igualmente que um indivíduo com antecedentes judiciários já tenha praticado atos de benemerência ou de especial valor social. Ao juiz compete extrairlhe a conta-corrente, para ver se há saldo credor ou devedor. ${ }^{139}$

Como bem ponderam Alberto Silva Franco e Juliana Belloque:

${ }^{138}$ Guilherme de Souza Nucci. Manual de Direito Penal: parte geral: parte especial. São Paulo: RT, 2007, p. 442.

${ }^{139}$ Nelson Hungria. Comentários ao Código Penal. Vol. V. $4^{a}$. ed., Rio de Janeiro: Forense, 1958, p. 471. 
A conduta social, como elemento norteador do juiz no processo de fixação da pena, constitui, apenas na aparência, uma inovação do legislador de 1984. É que tal conceito era abrangido pelo de antecedentes, e o simples fato de ter agora assumido a categoria de fator autônomo de determinação da pena não significa que não fosse antes objeto de consideração. A conduta social deve ser avaliada enquanto o comportamento desenvolvido pelo agente na comunidade em que vive, abrangendo as suas relações familiares e de vizinhança, o seu modo de vida no trabalho e nos espaços comunitários de lazer, as condutas que - de maneira recorrente - apresenta no inter-relacionamento humano e social. ${ }^{140}$

Estão entre os autores que também partilham desse entendimento Jair Leonardo Lopes, que dispõe "Quanto à 'conduta social', já era, de algum modo, considerada, quando se atendia aos antecedentes; contudo, quis o legislador dar ênfase a este aspecto da vida pregressa do agente $^{141}$.

Encontra-se também Miguel Reale Junior, ao afirmar que "Destaca-se, também, a referência à conduta social, dando-se ênfase, portanto, dentre os antecedentes, ao comportamento do réu no seu trabalho, no meio social, cidade, bairro, associações a que pertence, mesmo porque cada mais se acentua o nível de participação em entidades as mais diversas, e o comportamento social espelha em que medida o agente é digno de maior ou menor censura, por ter-se conduzido de molde a que o delito se inseriu no contexto de sua vida, ou constitua um fato alheio e isolado" ${ }^{\prime 142}$.

No mesmo sentido, Celso Delmanto, Roberto Delmanto, Roberto Delmanto Júnior e Fábio M. de Almeida Delmanto, para os quais a conduta social "Abrange seu comportamento no trabalho e na vida familiar, ou seja, seu relacionamento no meio onde vive"143.

Do mesmo modo o entendimento de Paulo José da Costa e Paulo José da Costa Júnior, ao afirmarem que:

Por conduta social deverá entender-se o papel que o acusado teve em sua vida pregressa, na comunidade em que se houver integrado. Se foi um homem voltado ao trabalho, probo, caridoso, altruísta, cumpridor dos deveres, ou se transcorreu os seus dias ociosamente, exercendo atividades parasitárias ou antissociais. Será ainda considerado o comportamento do agente na família, no ambiente de trabalho, de lazer ou escolar. Alguns se adaptam às normas de convivência social, outros reagem,

\footnotetext{
${ }^{140}$ Alberto Silva Franco e Juliana Belloque. Capítulo III. Da Aplicação da pena. In: Alberto Silva Franco e Rui Stoco (coords.). Código Penal e sua interpretação: doutrina e jurisprudência. 8a. ed. São Paulo: RT, 2007, p. 344345.

${ }^{141}$ Jair Leonardo Lopes. Curso de direito penal. Parte geral. 3. a ed. São Paulo: RT, 1999, p. 226.

142 Miguel Reale Júnior. Instituições de direito penal. Parte Geral. 3a . Ed. Rio de Janeiro: Forense, 2009 , p. 407.

${ }^{143}$ Celso Delmanto et al. Código Penal Comentado. 7. a ed. Rio de Janeiro: Renovar, 2007, p. 188.
} 
manifestando condutas de agressividade ou inconformismo. É este comportamento que servirá de guia ao magistrado na fixação da pena ${ }^{144}$.

Cezar Roberto Bitencourt dispõe que para avaliar a conduta social "Deve-se analisar o conjunto do comportamento do agente em seu meio social, na família, na sociedade, na empresa, na associação de bairro etc. Embora sem antecedentes criminais, um indivíduo pode ter sua vida recheada de deslizes, infâmias, imoralidades, reveladores de desajuste social. Por outro lado, é possível que determinado indivíduo, mesmo portador de antecedentes criminais, possa ser autor de atos beneméritos, ou de grande relevância social ou moral. No entanto, nem sempre os autos oferecem elementos para analisar a conduta social do réu; nessa hipótese, a presunção milita em seu favor" ${ }^{, 145}$.

Na contramão aos autores acima, Francisco Vani Benfica compreende a conduta social como uma inovação do legislador de 1984, ao dispor que "Esse elemento norteador do juiz no processo de aplicação da pena foi inovação do legislador de 1984. É levado em conta segundo o seu comportamento junto à comunidade, seu modo de agir nas suas ocupações, sua cordialidade ou agressividade, egocentrismo ou prestatividade, rispidez ou finura de trato"146.

Há outros doutrinadores que, igualmente relacionando a conduta social do agente ao seu ambiente familiar e profissional, ponderam a necessidade de que tal avaliação seja feita no ambiente próprio do condenado (seu estrato social), não podendo sofrer valoração negativa pelo magistrado, por este não considerar como adequado meio social.

Nesses termos, manifesta-se Fernando A. N. Galvão da Rocha, ao dispor que:

\begin{abstract}
Não se pode deixar de perceber que o critério da conduta social deve ser considerado em relação à sociedade na qual o acusado esteja integrado, e não em relação à sociedade formal dos homens tidos como de bem pelo juiz. Sem dúvida, um indivíduo que, por exemplo, more em uma favela e tenha um bom relacionamento com as pessoas que com ele interagem nesse ambiente social não pode receber uma valoração negativa, porque o juiz entende que existem melhores ambientes o desenvolvimento das relações sociais ${ }^{147}$.
\end{abstract}

\footnotetext{
${ }^{144}$ Fernando José da Costa e Paulo José da Costa Júnior. Curso de direito penal. 12. a ed. São Paulo: Saraiva, 2010, p. 245.

${ }^{145}$ Cezar Roberto Bitencourt. Tratado de direito penal: parte geral. São Paulo: Saraiva, 2013, p. 771-772.

${ }^{146}$ Francisco Vani Benfica. Da lei penal, da pena e sua aplicação, da execução da pena. Rio de Janeiro: Forense, 1995, p. 92.

${ }^{147}$ Fernando A. N. Galvão da Rocha. Direito Penal: curso completo: parte geral. $2^{\mathrm{a}}$ ed. Belo Horizonte: Del Rey, 2007 , p. 656.
} 
E também Ney Moura Teles quando diz que:

O juiz deve verificar a integração do condenado no meio social em que ele vive, e não no meio social que o juiz considera adequado. Deve verificar se seu comportamento é compatível com o aceito no ambiente de seu estrato social, por exemplo, na favela, com todas as suas características. Se, em seu meio, o condenado cumpre seus deveres, suas obrigações sociais, respeita os valores ali cultivados, convive harmonicamente com seus pares, tal circunstância lhe será favorável, militará em seu favor, beneficiando-o com pena-base próxima do mínimo. Se, todavia, o condenado não se ajusta às regras da comunidade - é por ela considerado um revoltado -, se a ela se opõe, se não a respeita, se é rejeitado, por suas atitudes, por seus concidadãos, então terá um comportamento social desajustado a seu meio, o que importará em considerar a circunstância desfavorável, tendente a autorizar o afastamento da pena do grau mínimo? Essa é uma circunstância que nada tem a ver com o fato criminoso praticado pelo agente e que diz respeito exclusivamente a seu passado anterior ao crime e à sentença. Tanto quanto os antecedentes, essa circunstância colide com o princípio da culpabilidade, e só pode ser examinada do ponto de vista positivo. Se o condenado tiver conduta social harmônica, ajustada a seu meio, será beneficiado por isso, mas, do contrário, a circunstância não deve ser levada em consideração no momento da fixação da pena, pois que representaria o julgamento do homem pelo que ele é, e não do homem pelo que ele fez ${ }^{148}$

No que tange ao posicionamento de Ney Moura Teles, acima esposado, vê-se que ele não concorda com a análise da circunstância da conduta social, para o fim de prejudicar o condenado, o que entende como ofensa ao princípio da culpabilidade, uma vez estar-se punindo o agente pelo o que é e não pelo que fez. A análise dessa circunstância, sob o ponto de vista desse autor seria justificada apenas para beneficiar a situação do réu.

Em sentido um pouco distinto é o entendimento de André Stefam, para quem só é justificável a análise dessa circunstância, na dosimetria da pena, se a conduta social do agente tiver alguma importância direta com o fato praticado. Em suas próprias palavras:

É preciso frisar que não se trata de punir o agente por seu modo de vida (seja ela qual for), porquanto a pena não pode ser mensurada com base em tais elementos. Conforme já tivemos a oportunidade de analisar, o Direito Penal democrático baseiase no fato e não no autor. Daí por que só devem ser tomadas como relevantes para a dosimetria da pena atitudes que tenham alguma relação com o ato praticado. Por exemplo: pode o juiz considerar má a conduta social de quem agride verbalmente seus colegas de trabalho, quando condenar o réu por delito de ameaça praticada no ambiente laborativo $^{149}$.

\footnotetext{
${ }^{148}$ Ney Moura Teles. Direito penal: parte geral. São Paulo: Atlas, 2006, p. 365.

${ }^{149}$ André Stefam. Direito penal. 1. São Paulo: Saraiva, 2010, p. 342.
} 
Por fim, importante ponderar o posicionamento de Rogério Greco, que se coaduna com o entendimento do Superior Tribunal de Justiça, na Súmula 444, mesmo antes de sua publicação, na medida em que afasta da análise da conduta social aquilo que se proibiu considerar como antecedentes. Entende, portanto, que:

\begin{abstract}
Por conduta social quer a lei traduzir o comportamento do agente perante a sociedade. Verifica-se o seu relacionamento com seus pares, procura-se descobrir o seu temperamento, se calmo ou agressivo, se possui algum vício, a exemplo de jogos ou bebidas, enfim, tenta-se saber como é seu comportamento social, que poderá ou não ter influenciado no cometimento da infração penal. Importante salientar que conduta social não se confunde com antecedentes penais, razão pela qual determinou a lei as suas análises em momentos distintos. Alguns intérpretes, procurando, permissa vênia, distorcer a finalidade da expressão conduta social, procuram fazê-la de 'vala comum' nos casos em que não conseguem se valer dos antecedentes penais do agente para que possam elevar a pena-base. Afirmam alguns que se as anotações na folha de antecedentes criminais, tais como inquéritos policiais ou processos em andamento, não servirem para atestar maus antecedentes dos réus, poderão ser aproveitadas para fins de aferição de conduta social. Mais uma vez, acreditamos, tenta-se fugir à finalidade da lei. Os antecedentes traduzem o passado criminal do agente; a conduta social deve buscar aferir o seu comportamento perante a sociedade, afastando tudo aquilo que diga respeito à prática de infrações penais. Assim, se inquéritos em andamento não poderão servir para fins de verificação de maus antecedentes, da mesma forma não se prestarão para efeitos de aferição de conduta social. Pode acontecer, até mesmo, que alguém tenha péssimos antecedentes criminais, mas, por outro lado, seja uma pessoa voltada à caridade, com comportamentos filantrópicos e sociais invejáveis. Concluindo, não podemos confundir conduta social com antecedentes penais. Estes jamais servirão de base para a conduta social, pois esta abrange todo o comportamento do agente no seio da sociedade, afastando-se desse raciocínio seu histórico criminal, verificável em sede de antecedentes penais. ${ }^{150}$
\end{abstract}

Das disposições acima, vê-se o quão aberto é o conceito de conduta social. Podendo ser aferida na vida particular do indivíduo, por meio de seus relacionamentos pessoais, profissionais, e formas de condução de vida, tendo a tendência de ditar comportamentos que as pessoas devem possuir, privilegiando-se sempre a bondade, a caridade. E de outro lado, mal avaliando aqueles que são imorais, viciados, ainda que tais fatos não tenham qualquer relação com os crimes praticados.

A Constituição Federal assegura que o indivíduo não sofrerá pena sem prévia cominação legal. O princípio da legalidade é a mais pura manifestação desta garantia. No

${ }^{150}$ Rogério Greco. Curso de direito penal: parte geral. Niteroi: Impetus, 2008, p. 564. 
entanto, como compatibilizá-la com a possibilidade de o juiz aumentar a pena-base com fundamento em conduta social?

\begin{abstract}
No decurso da sua evolução, a partir da Magna Carta, dos documentos norteamericanos e da Revolução Francesa, o princípio da legalidade foi dissociando do seu contexto as várias funções de garantia que hoje apresenta: não há crime nem pena sem lei anterior, e então o princípio se opõe à retroatividade da norma penal incriminadora, trazendo a necessária precisão e segurança ao Direito; não há crime nem pena sem lei escrita, o que importa em negar ao Direito costumeiro função criadora ou agravante de tipos ou sanções penais; não há crime nem pena sem lei estrita, com o que se impõe uma limitação à aplicação da lei e se torna defeso, do domínio das normas incriminadoras, o emprego da analogia. Esse princípio, que é uma das características dos regimes democráticos nascidos das idéias liberais do século XVIII, do liberalismo e do individualismo das correntes filosóficas e políticas que então se desenvolveram, tem sido posto modernamente em discussão e vem sendo abolido mesmo em algumas legislações, ou como expressão de um regime de hipertrofia estatal, em que a defesa de um sistema político, de um partido, de uma classe social, exige uma ordem penal que se tem chamado de autoritária, em condição de atuar sem a limitação daquele princípio liberal, ou como forma de transição entre um Direito Penal de normas incriminadoras tipificadas e um Direito Penal sem parte especial e sem dosimetria das penas. ${ }^{151}$
\end{abstract}

Como conciliar esta garantia constitucional, quando o indivíduo, que praticou um crime, é duplamente penalizado. Pelo que fez, e pelo modo que conduz sua vida, haja vista a fixação de pena acima do mínimo legal, com fundamento em má (a critério do julgador) conduta social.

Como bem pondera Mariângela Gama de Magalhães Gomes, "A concepção substancial que é conferida ao Estado Democrático de Direito, expresso na Constituição brasileira, implica que a sua política criminal, que tem como fundamentos a liberdade e a dignidade humana, não pode desconsiderá-las a ponto de converter as pessoas em meros instrumentos ou sujeitos de tutela. O ponto de partida é, pois, a relação livre destas com o sistema, sendo este composto por um Estado a serviço do indivíduo voltado para sua felicidade, e a pessoa reconhecida como ente autônomo e sujeito de direitos e garantias. Podese dizer, com isto, que o programa político criminal deve estar dirigido a propiciar o máximo de liberdade para os indivíduos." 152

\footnotetext{
${ }^{151}$ Aníbal Bruno. Direito Penal: parte geral. Tomo I. Rio de Janeiro: Forense, 2003, p. 125. (Destaques nossos). ${ }^{152}$ Mariângela Gama de Magalhães Gomes. O princípio da proporcionalidade no direito penal. São Paulo: RT, 2003, p. 73.
} 
Se a Carta Magna brasileira garante a máxima liberdade aos seus cidadãos, a ponto de protegê-los, inclusive, frente à força do próprio Estado punidor, exigindo o cumprimento de regras claras relativas ao limite de intervenção punitiva, tais como menos aflitiva, estigmatizante, dentre outros, não parece lógico que o sujeito experimente valoração negativa pela forma que conduz sua vida, e pior, sofra penalização criminal por isso.

Parágrafo 1. O princípio do Estado de Direito conduz, como na exposição anterior já por várias vezes se revelou, a que a protecção dos direitos, liberdades e garantias seja levada a cabo não apenas através do direito penal, mas também perante o direito penal. Até porque uma eficaz prevenção do crime, que o direito penal visa em último termo atingir, só pode pretender êxito se à intervenção estadual forem levantados limites estritos - em nome da defesa dos direitos, liberdades e garantias das pessoas perante a possibilidade de uma intervenção estadual arbitrária ou excessiva. A esta possibilidade de arbítrio ou de excesso se ocorre submetendo a intervenção penal a um rigoroso princípio de legalidade, cujo conteúdo essencial se traduz em que não pode haver crime, nem pena que não resultem de uma lei prévia, escrita, estrita e certa (nullum crimen, nulla poena sine lege) ${ }^{153}$.

A conduta social analisada pela doutrina, como visto acima, não é taxativa do que realmente se engloba no conceito, falando vaga e genericamente, da convivência familiar, social e profissional; de probidade e moralidade. Critérios complexos de conceituar e repletos de conteúdos subjetivos.

Para analisá-la, de um modo geral, entende-se que o julgador deverá basear-se nos conteúdos do interrogatório e testemunhos.

O magistrado precisa conhecer a pessoa que está julgando, a fim de saber se merece uma reprimenda maior ou menor, daí por que a importância das perguntas que devem ser dirigidas ao acusado, no interrogatório, e às testemunhas, durante a instrução. ${ }^{154}$

Obviamente que, para encontrar elementos suficientes para a justa individualização da pena, o juiz deve coletá-los ao longo da instrução, não se preocupando unicamente, como tem sido hábito de muitos, com a colheita da prova da materialidade do delito e de sua autoria. Sobre o tema, no dizer de Sérgio Salomão Shecaria e Alceu Corrêa Junior, referindo-se ao disposto no art. 59, caput, do Código Penal, "a consideração dos elementos mencionados dependem de uma boa colheita de provas na fase instrutória. Muitas das questões que, posteriormente, servirão para fundar o quantum da pena fixada dependem de um eficiente interrogatório (art. 188 do CPP [atual art. 187], o que nem sempre é feito. Como saber, por exemplo, sobre a

\footnotetext{
153 Jorge de Figueiredo Dias. Direito Penal: parte geral: tomo I: questões fundamentais: a doutrina geral do crime. São Paulo: RT; Portugal: Coimbra Editora, 2007, p.177.

${ }^{154}$ Guilherme de Souza Nucci. Individualização da Pena. $2^{\mathrm{a}}$ ed. São Paulo: RT, 2007, p. 182.
} 
conduta social prévia do agente do crime se o próprio agente e as testemunhas arroladas não o disseram? ${ }^{155^{2}}$

No enfoque da conduta social, não pode o Magistrado restringir-se a afirmar que o réu "aparentemente não possui boa conduta social", sem tomar por base minimamente os elementos probatórios dos autos. Não bastam meras conjecturas, é necessário que se ponderem as provas, geralmente orais, produzidas nos autos: a palavra das testemunhas que conviveram com réu (inclusive das abonatórias), eventuais declarações, atestados, abaixo-assinados, etc, que demonstrem um comportamento habitual. A constatação de um fato isolado na vida do condenado não revela sua conduta social, que é sempre permanente. ${ }^{156}$

Entretanto, a experiência profissional, muitas vezes, mostra que os julgadores não estão preocupados em perquirir a conduta social do indivíduo, na medida em que indeferem oitivas de testemunhas de antecedentes, não expedem cartas precatórias para tal fim, e para a expedição de rogatórias, exigem que a defesa faça prova da imprescindibilidade de sua oitiva, mas, em nenhum momento, aceitam efetivamente, ser tal oitiva imprescindível.

Tal fato, de certa forma, corrobora a hipótese de que a existência desse critério se deve somente à justificação do aumento da pena-base, em prejuízo do indivíduo, pois do contrário, o julgador teria mais interesse em colher provas, que normalmente são trazidas pela defesa, demonstrando a boa conduta do réu.

O Direito Penal não pode ser instrumento para imposição e reforço de padrões morais, sob o risco de retrocesso aos tristes períodos ditatoriais, onde a pura expressão era vetada. Viver era proibido.

O direito de ser livre, de viver conforme as crenças, orientações sexuais, escolhas políticas, de freqüentar bares, ser tatuado, ser usuário de drogas, enfim, não pode ser mitigado para fins de controle de padrões e comportamentos. O indivíduo não pode servir de instrumento de controle social.

\footnotetext{
${ }^{155}$ Guilherme de Souza Nucci. Individualização da Pena. $2^{\mathrm{a}}$ ed. São Paulo: RT, 2007, p. 312-313.

${ }^{156}$ Juliana de Andrade Colle. Critérios para a valoração das circunstâncias judiciais (art. 59, do CP) na dosimetria da pena. Jus Navigandi, Teresina, ano 10, n. 572, 30 jan. 2005. Disponível em: 〈http://jus.com.br/artigos/6232〉. Acesso em: 13 set. 2013.
} 
A imposição de que o fato típico seja ofensivo indica a existência de quatro funções conexas a esse princípio, como ensina Nilo Batista. A primeira diz respeito à proibição da incriminação de uma atitude interna, uma vez que ideias, convicções, desejos, aspirações e sentimentos humanos não podem fundamentar um tipo penal, nem mesmo quando estejam orientados para a prática de um delito (a simples cogitação não é punível). A segunda função é proibir a incriminação de uma conduta que não exceda o âmbito do próprio autor. Deste modo, os atos preparatórios para a prática de um crime que não ocorre não podem ser punidos, assim como o mero acordo entre duas ou mais pessoas para a prática de um delito não autoriza a punição se este não se realizar: sob este fundamento, são igualmente proibidas as incriminações de autolesão, do suicídio e do uso de drogas, pois apesar de haver uma conduta externa lesionando um bem jurídico, esta não excede a esfera do próprio autor. A terceira função é no sentido de proibir a incriminação de simples estados ou condições existenciais, posto que o direito penal do autor é incompatível com as exigências do Estado de Direito; veda-se, dessa forma, a incriminação de um simples estado ou condições do homem, tendo em vista o respeito à autonomia moral da pessoa, pois o direito, sendo ordem reguladora da conduta, jamais pode apenar o ser, senão o fazer dessa pessoa. A quarta função, por fim, é proibir a incriminação de condutas desviadas, ou seja, orientadas em direção oposta àquela aprovada pela coletividade, que não afetem qualquer bem jurídico; esta proibição funda-se no chamado "direito à diferença", de práticas e hábitos de grupos minoritários que não podem ser criminalizados. ${ }^{157}$

O indivíduo só pode responder por aquilo que fez, e não pelo que é, por onde vive, ou com quem anda. O Direito Penal deve estar estritamente vinculado ao fato, reprimindo condutas lesivas a bens jurídicos concretos; se abstendo de penalizar pensamentos e comportamentos sociais, que em nada concorreram para a prática de crime.

Como leciona Luigi Ferrajoli, "a tentação comum a todas essas técnicas de atenuação ou dissolução da estrita legalidade penal é, na realidade, punir não quia prohibitium, senão quia peccatum, e, em conseqüência, perseguir nem tanto pelo que se faz, senão pelo que é ${ }^{158,}$.

Pelos diversos conceitos de conduta social expostos, bem como pelo que os autores reputam válido para melhor analisá-la, é importante notar o quanto de conteúdo moral ainda se projeta sobre esta circunstância judicial.

Aliás, com razão a crítica de Alexandre Morais da Rosa, quando diz que:

A conduta social, também na linha da 'mentalidade criminológica' (Rauter) vasculha qualquer situação da vida pessoal para ali encontrar, retoricamente, um

\footnotetext{
${ }^{157}$ Mariângela Gama de Magalhães Gomes. O princípio da proporcionalidade no direito penal. São Paulo: RT, 2003, p. 89-90.

${ }^{158}$ Luigi Ferrajoli. Direito e razão: teoria do garantismo penal. Tradução de Ana Paula Zomer et al. São Paulo: RT, 2002, p. 36.
} 
motivo para majoração da pena. Qualquer pessoa possui na sua 'história pregressa' situações traumáticas, geradoras de situações psicológicas (neuroses, psicoses, etc.) e qualquer acontecimento é pescado para justificar a majoração da pena. O passado é retomado, não no sentido que pretende a psicanálise, mas para justificar o presente, a pena. 2 - Rauter sustenta que partindo de um modelo de família ideal - pai, mãe, casa, filhos, carro, cachorro, etc - valores típicos da classe dominante, acolhidos como paradigma e obliterando qualquer contradição e luta de classes, no melhor estilo de justiça neoliberal, o parecer aponta um lugar-comum, um 'estereótipo', fundamentador da exasperação: a) famílias onde ocorreu a morte do pai ou o abandono precoce por parte deste; b) famílias onde o pai bebe, está preso ou doente; c) famílias onde a mãe cria o filho sem o pai, ou onde a mãe tem filhos de homens diferentes; d) famílias onde a mãe está ausente, mesmo que seja por ter que trabalhar; e) famílias onde a mãe bebe, está presa, é prostituta, etc. Ninguém discute que a 'seleção' e o 'etiquetamento' daqueles que serão pegos pelas malhas da Justiça recai sobre a população excluída (Cap. 6o), onde o modelo 'tradicional' de família não vigora, e é tão democrático como o de qualquer outro; inexiste um modelo 'chapa branca' de família, malgrado alguns totalitarista ainda de plantão. A miséria, a exclusão, então, no momento da aplicação da pena são novamente invocados para, desde uma perspectiva de 'periculosidade' e 'Defesa Social', prevenir-se do 'outro', do 'estranho' (Freud), prendendo-o o maior tempo possível. Pura canalhice. ${ }^{159}$

De acordo com Cezar Roberto Bitencourt, uma vida cheia de imoralidades contaria em desfavor de seu agente. Aqui, caberia questionar que tipo de imoralidade o autor estaria se referindo, e sob quais critérios poderia ser aferida.

Poderia ser reputado imoral aquele que, mesmo casado, e participante de uma sociedade que elegeu a monogamia (e na qual não seja crime o adultério) não se absteve de ter outros parceiros?

Para exemplificar a fragilidade dos julgamentos, com base em critérios muito abertos, é interessante mencionar estudo relatado, por David Eagleman, no livro Incógnito: as vidas secretas do cérebro, em que se verificou, por exemplo, que a monogamia não seria uma decisão baseada em caráter moral, mas sim uma programação genética, ligada à recepção do hormônio vasopressina.

Relacionada com a questão do vínculo com os pais está a da fidelidade ao parceiro. O bom senso nos diria que a monogamia é uma decisão baseada em caráter moral, não é? Mas isso, antes de mais nada, leva à questão do que constituiria "caráter". Poderia também ser guiado por mecanismos abaixo do radar da consciência? [...] A vasopressina se liga a receptores numa parte do cérebro chamada de núcleos accumbens, e o vínculo medeia uma sensação agradável que se torna associada com a fêmea em questão. Isso o prende à monogamia, que é conhecida como ligação do par. Se você bloquear este hormônio, a ligação do par desaparecerá. [...] Será que a

\footnotetext{
${ }^{159}$ Alexandre Morais da Rosa. Decisão no Processo Penal como Bricolagem de Significantes. Tese de Doutoramento apresentada à Universidade Federal do Paraná, 2004, p. 354-355. (Destaques do autor).
} 
vasopressina tem importância nos relacionamentos humanos? Em 2008, uma equipe de pesquisa do Instituto Karolinska, na Suécia, examinou o gene para o receptor de vasopressina em 552 homens em longos relacionamentos heterossexuais. Os pesquisadores descobriram que uma seção do gene chamada RS3 334 pode ter números variáveis: um homem pode não carregar cópias desta seção, um cópia, ou duas delas. Quanto mais cópias, mais fraco o efeito que a vasopressina da corrente sanguínea teria no cérebro. $\mathrm{O}$ resultado foi de uma simplicidade surpreendente. $\mathrm{O}$ número de cópias correlacionava-se com o comportamento de ligação do par nos homens. Homens com mais cópias de RS3 334 tiveram pior classificação nas medições de ligação do par - inclusive medições de força de seus relacionamentos, problemas conjugais percebidos e qualidade conjugal percebida pela esposa. Aqueles com duas cópias tinham uma probabilidade maior de não se casar e, se fossem casados, era mais provável que tivessem problemas conjugais. ${ }^{160}$

Entende-se relevante relatar esta experiência para mostrar que muitas vezes, somos tomados por julgamentos morais, daquilo que se convencionou como correto em certa sociedade, e descuidamos de possíveis causas físicas e até químicas de determinados comportamentos, como no caso acima.

Apesar de se entender que independentemente da causa ou origem que motive o comportamento, que no campo da moral, até poderia ser reprovável; no campo do direito, não temos como admiti-lo, principalmente como circunstância a ser valorada negativamente, no momento da fixação de pena, pela prática de delito, totalmente independente.

Como ponderam Eugênio Raúl Zaffaroni e José Henrique Pierangeli quando dissertam sobre Aristóteles e a culpabilidade pela conduta de vida:

O direito não é uma teoria moral, e sim jurídica. [...] Aristóteles não escreveu sua Ética Nicomaquéia partindo do que devia ter em conta que "ninguém será obrigado a fazer ou deixar de fazer alguma coisa senão em virtude de lei" $\left(\mathrm{CF}\right.$, art. $\left.5^{\circ}\right)$. Este princípio não tem vigência no campo da moral, mas é o fundamento de todo o direito penal, de modo que, se o abandonamos, o direito penal deixa de cumprir sua função de segurança jurídica e passa a pretender cumprir qualquer outra (a defesa da superioridade da raça, da ditadura do proletariado etc.), ainda que, na realidade, esteja cumprindo a função de dar sustento àqueles que detêm o poder conforme o seu arbítrio. ${ }^{161}$

E continuam:

${ }^{160}$ David Eagleman. Incógnito: as vidas secretas do cérebro. Tradução de Ryta Vinagre. Rio de Janeiro: Rocco, 2012, p. 108-109.

${ }^{161}$ Eugenio Raúl Zaffaroni e José Henrique Pierangeli. Manual de direito penal brasileiro: parte geral. $2^{\mathrm{a} e d}$., São Paulo: RT, 1999, p. 609-610. 
Exemplificando: o sujeito de maus hábitos os terá adquirido por freqüentar tabernas e prostíbulos; esta conduta é claramente atípica, mas quando a ele se reprova "sua conduta de vida", que desemboca num homicídio, estaremos reprovando sua conduta anterior de freqüentar tabernas e prostíbulos, isto é, a reprovação da conduta de vida é a reprovação de condutas anteriores atípicas, que o juiz considera contrárias à ética (quando na realidade podem ser contrárias apenas a seus próprios valores subjetivos). A culpabilidade pela conduta de vida é o mais claro expediente para burlar a vigência absoluta do princípio da reserva e estender a culpabilidade em função de uma actio inmoral in causa, por meio da qual se pode chegar a reprovar os atos mais íntimos do indivíduo. Poucos conceitos podem ser mais destrutivos para uma sã concepção do direito penal. Se, com o exposto, a teoria já não resultasse suficientemente aberrante, cabe acrescentar outro argumento muito claro: a personalidade do homem integra-se com caracteres adquiridos mediante vivência ou condutas anteriores, mas também com elementos herdados, isto é, com elementos que provêm de uma carga genética recebida. Uma reprovação da personalidade implica uma reprovação da carga genética, isto é, a reprovação de algo que é absolutamente estranho a qualquer conduta do sujeito. ${ }^{162}$

No campo da neurociência, pode-se encontrar explicação química para tudo. Aliás, a se pautar exclusivamente por seus estudos, e dificilmente algum indivíduo seria responsabilizado, uma vez que segundo afirmam os neurocientistas, nossa parte consciente é a que menos tem controle sobre a maquinaria mental, portanto, a que menos nos determina. ${ }^{163}$

Em uma passagem interessante do livro Incógnito, em que o autor trata dos danos cerebrais que alteraram completamente o comportamento dos indivíduos afetados, fica claro que até o livre-arbítrio resta questionado. Até que ponto se é, de fato, livre para se autodeterminar segundo a lei, e/ou as regras sociais de convivência, se somos tão suscetíveis a toda e qualquer alteração química em nosso cérebro, a carga biológica, ao ambiente em que crescemos; questionando-se que as pessoas não escolhem seu caminho de desenvolvimento.

\footnotetext{
${ }^{162}$ Eugenio Raúl Zaffaroni e José Henrique Pierangeli. Manual de direito penal brasileiro: parte geral. $2^{\mathrm{a} e d}$., São Paulo: RT, 1999, p. 610.

163 "não somos os únicos que dirigem o barco de nosso comportamento, pelo menos não tanto como acreditamos. Quem nós somos corre bem abaixo da superfície de nosso acesso consciente, e os pormenores remontam a tempos anteriores a nosso nascimento, quando o encontro de um espermatozoide com um óvulo nos dotou de determinados atributos e não de outros. Quem podemos ser começa com nossas plantas moleculares - uma série de códigos alheios escritos em sequências invisíveis de ácidos - bem antes de termos algo a ver com isso. Somos o fruto de nossa história microscópica e inacessível." (David Eagleman. Incógnito: as vidas secretas do cérebro. Tradução de Ryta Vinagre. Rio de Janeiro: Rocco, 2012, p. 171-172).
} 
Independentemente de se acatar ou não os argumentos dos neurocientistas, concedendo-se valor/crédito para suas experiências e pesquisas, é fato que não convém fechar os olhos para o estudo que eles apresentam.

No que cabe ao tema da conduta social, que é o objeto deste tópico do trabalho, tal estudo tem especial valia, na medida em que desmente muitas de nossas crenças morais de que determinados comportamentos, mal vistos, mal avaliados, estão dentro do autodomínio de seus portadores, e que poderiam agir de outra maneira se assim quisessem.

Com isto, não se quer desculpar determinados comportamentos, quer-se, na verdade, ponderar a existência de outras explicações para tais fenômenos comportamentais, que estariam completamente afastados da possibilidade de se fazer diferente, de atuar em conformidade com as regras morais da sociedade.

Esse novo viés de compreender os acontecimentos humanos também combate a manutenção da conduta social dos indivíduos, como critério de fixação de pena, na medida em que se questiona até a existência da liberdade para se determinar de uma forma ou outra, que dirá para questionar atitudes que não são criminosas, consoante as disposições legais.

Se hoje em dia, estuda-se o impacto destas teorias no direito penal, sob o ponto de vista da atribuição da responsabilidade penal por condutas, efetivamente, criminosas, o que dizer da atribuição de penalidade, para condutas que nada tem de ilícitas, ferindo, no máximo a moral do senso comum de determinada sociedade ou a expectativa de valores que ela busca praticar.

Além dos aspectos abordados nesse item, que visam expor a questão sob o ponto de vista da liberdade do ser humano se autodeterminar, e nesse exercício constitucionalmente garantido, não poder ser penalizado por ser diferente, fora do padrão, esclarece-se que no Capítulo $4^{\circ}$, a abordagem para a defesa do afastamento dessa circunstância judicial será feita por outro ângulo, dessa vez, pelo prisma de quem a analisa, o julgador. 


\subsection{Personalidade ${ }^{164}$}

A circunstância judicial personalidade do agente revela-se um critério ainda mais questionável, principalmente porque tal conceito, indiscutivelmente, não advém da ciência jurídica, não podendo ser atestado por juristas.

Segundo Willian Stern, “A personalidade humana não é, evidentemente, uma estrutura rígida, definida em todas as direções e encarcerada no seu "ser assim" individual, como uma prisão; bem pelo contrário, ela contém algo de polivalente, de subjacente, de periférico. Assim, em cada homem, o âmbito das possibilidades é muito mais vasto do que a realidade

164 "Em grande medida superado nos meios acadêmicos, Lombroso ainda se faz sentir quando, por exemplo, percebemos a persistência da personalidade no art. 59 do Código Penal (bem como em demais diplomas vigentes, como é o caso da Lei 11.343/06) e a insistência dos tribunais em seguir lhe dando ouvidos. [...] O problema, entretanto, não reside exatamente em como se determinar a personalidade legalmente prevista, mas na questão da personalidade em si. Nesse sentido, questões de três ordens deveriam recomendar o imediato afastamento do conceito do nosso corpo legislativo penal. A primeira é intrassistêmica e diz respeito a certa incoerência. Em rápida análise, temos, no Brasil, um sistema legal penal baseado na dicotomia pena-medida de segurança, esta associada a uma noção de recuperação/tratamento de patologias que, à revelia da vontade pura de um agente, determinariam uma prática criminosa, e aquela derivada da responsabilidade (imputabilidade) do sujeito. A seguirmos tal distinção, se uma conduta é determinada por uma personalidade "desajustada", "deformada", ou mesmo "voltada à prática criminosa" - como constantemente se lê em decisões - qual a pertinência da categoria personalidade dentro de um sistema de penas fundamentada na imputabilidade? Faz sentido que alguém tenha sua pena exacerbada com base em seu caráter ou seus traços de comportamento? Em um nível intrassistêmico, portanto, trata-se da incompatibilidade de um direito penal do autor, em uma principiologia orientada para um direito penal do fato. Uma segunda ordem de questões toca à inconstitucionalidade da influência da personalidade no momento da fixação das penas. Ao estatuir a liberdade de consciência, a vedação da discriminação e a presunção de inocência, a Constituição Federal aponta para uma dupla proibição. A primeira delas diz respeito à impossibilidade de o Estado valer-se de juízos morais ou "moralizadores" no campo jurídico. Ninguém pode ser, assim, penalizado por aquilo que é em termos políticos, religiosos, ideológicos, étnicos. O Estado não é somente laico, mas também amoral. A segunda de tais proibições é a de considerar-se elementos anteriores à prática do delito como critérios de exacerbação de pena. Explica-se: àquele que comete um homicídio simples deve corresponder exatamente a mesma pena daquele que, em condições idênticas, cometeu exatamente o mesmo crime, independentemente de juízos morais que possam recair sobre uma suposta "personalidade" essencial ou tendencialmente criminosa. Surge uma impossibilidade objetiva de atender-se ao princípio constitucional da fundamentação das decisões, sendo que, não raro, se faz referência em sentenças e acórdãos a uma personalidade "voltada à prática de delitos", em uma tautologia lógica e constitucionalmente inadmissível. A terceira ordem de questões é, por assim dizer, externa. Não há qualquer consenso mínimo no terreno das ciências do comportamento que autorize uma visão razoável sobre o conteúdo de "uma personalidade desajustada". [...]. Ademais, as únicas conseqüências práticas da previsão de atribuir-se à personalidade o poder de elevar uma pena são a perpetuação de uma mentalidade evolucionista arcaica e o cultivo de um preconceito maniqueísta que divide o mundo entre amigos e inimigos, cidadãos de bem e criminosos, condutas normais e personalidades "desajustadas". Sobre esse pequeno termo escondido sobre o art. 59 do Código Penal, doutrina e jurisprudência, salvo exceções, têm-se mantido silentes, ou assumido uma postura racionalizadora, amparada no mito de um legislador a priori sábio e infalível que, por algum motivo, deve ter feito constar no ordenamento positivo a referência à personalidade do agente. (Marcelo Soares de Souza. Lombroso entre nós: a perspectiva da personalidade como critério de aumento de pena no direito brasileiro. Boletim IBCCRIM, São Paulo, ano 19, $\mathrm{n}$ 299, dez., 2011, p. 12). 
correspondente; é preciso que ele faça repercutirem essas possibilidades, se pretende compreender a vida psíquica de outrem. Como poderia o psicólogo ocupar-se, agora, da psicologia do criminoso, logo da do artista, e em seguida da criança ou da do homem primitivo, se algo de tudo isso não se encontrasse - em germe e em potência - dentro dele?"165

Referido autor, apontado como um dos pioneiros da psicologia da personalidade, não a conceitua de forma fechada e única, dispondo, pelo contrário, pela múltipla possibilidade de manifestação em cada homem.

Por assim acreditar, entende que "por este valor informativo insubstituível na formação do homem, a psicologia deveria estar incluída na preparação profissional de qualquer indivíduo que, como, por exemplo, o professor, o juiz, o médico, tenha de compreender e tratar, mais tarde, a vida psíquica de outrem.",166

Compartilhamos do posicionamento de Willian Stern, quanto à necessidade da inserção da psicologia na formação dos profissionais que trabalharão com a saúde mental de outras pessoas, e acrescentamos, ainda, a necessidade, conforme será esclarecido no Capítulo $4^{\circ}$, que estes profissionais se submetam a um processo de autoconhecimento, que certamente os auxiliará a reconhecer diversas realidades, muito distantes do mundo hermético que se encontram, e dos quais partem para julgar os outros.

A seguir, breve levantamento de doutrinadores jurídicos acerca do conceito de personalidade. Fica claro do posicionamento da maioria deles o resquício do Direito Penal do Autor, remontando a teorias que visavam atestar à propensão biológica do indivíduo à delinqüência.

Esclarecem Eugênio Raúl Zaffaroni e Nilo Batista que:

Enquanto, para alguns autores, o delito constitui uma infração ou lesão jurídica, para outros ele constitui o signo ou sintoma de uma inferioridade moral, biológica ou psicológica. Para uns, seu desvalor - embora haja discordância no que tange ao objeto - esgota-se no próprio ato (lesão); para outros, o ato é apenas uma lente que permite ver alguma coisa daquilo onde verdadeiramente estaria o desvalor e que se encontra em uma característica do autor. Estendendo ao extremo esta segunda opção, chega-se à conclusão de que a essência do delito reside numa característica do autor,

\footnotetext{
${ }^{165}$ Willian Stern. Psicologia geral. Tradução de Fritz Berkemeier. Lisboa: Fundação Calouste Gulbenkian, 1981, p, 93.

${ }^{166}$ Willian Stern. Psicologia geral. Tradução de Fritz Berkemeier. Lisboa: Fundação Calouste Gulbenkian, 1981, p, 93.
} 
que explica a pena. $\mathrm{O}$ conjunto de teorias que este critério compartilha configura $\mathrm{o}$ chamado direito penal de autor ${ }^{167}$.

Há muita dissonância na doutrina jurídica acerca do conceito de personalidade, uns a definem como algo característico de cada ser, sendo um dado particular de manifestação individual, que não se repete em outra pessoa, da mesma forma e com igual intensidade - "a personalidade é a forma viva fundamental do indivíduo humano por oposição a todos os outros." $" 168$

Outros a entendem como traços genéticos, herdados, ou caracteres adquiridos, que influenciam o comportamento humano.

A personalidade é um complexo, herdado ou adquirido, que influi no comportamento humano. Má personalidade não é o mesmo que maus antecedentes. Ela diz respeito à índole do agente, maneira de agir e de sentir, grau de senso moral. Há agentes que, na prática de certos crimes, revelam distorções psicológicas, agindo audaciosamente ou pouco ou nada lhes importando, por exemplo, se o resultado de sua ação deletéria seja difundida, como no caso do traficante habitual de drogas ou em outros casos em que sua distorção psicológica rompe as amarras da moral ${ }^{169}$

Trata-se do conjunto de caracteres exclusivos de uma pessoa, parte herdada, parte adquirida. Exemplos: agressividade, preguiça, frieza emocional, sensibilidade acentuada, emotividade, passionalidade, bondade, maldade. 'A personalidade tem uma estrutura muito complexa. Na verdade é um conjunto somatopsíquico (ou psicossomático) no qual se integra um componente dinâmico- humoral ou fisiológico, que é o temperamento; e o caráter, que é a expressão psicológica do temperamento [...] $\mathrm{Na}$ configuração da personalidade congregam-se elementos hereditários e sócio-ambientais, o que vale dizer que as experiências da vida contribuem para a sua evolução. Esta se faz em cinco fases, bem caracterizadas: infância, juventude, estado adulto, maturidade e velhice' (Guilherme Oswaldo Arbenz, Compêndio de medicina legal). [...] Por outro lado, personalidade não é algo estático, mas encontra-se em constante mutação. Estímulos e traumas de toda ordem agem sobre ela. Não é demais supor que alguém, após ter cumprido vários anos de pena privativa de liberdade em regime fechado, tenha alterado sobremaneira sua personalidade. O cuidado do magistrado, nesse prisma, é indispensável para realizar justiça $^{170}$.

O agente será mais ou menos reprovável se, na formação de sua personalidade (que se compõe de genótipos e fenótipos), tenha dado prevalência ao desenvolvimento de

\footnotetext{
${ }^{167}$ Alejandro Alagia et al. Direito Penal Brasileiro I. Rio de Janeiro: Revan, 2003, p. 131.

${ }^{168}$ Jorge Figueiredo Dias. Liberdade, culpa e direito penal. Coimbra: Biblioteca Jurídica Coimbra, 1983, p, 263.

${ }^{169}$ Francisco Vani Benfica. Da lei penal, da pena e sua aplicação, da execução da pena. Rio de Janeiro: Forense, 1995, p. 92.

${ }^{170}$ Guilherme de Souza Nucci. Manual de direito penal: parte geral e especial. 3. ${ }^{a}$ ed. São Paulo: RT, 2007, p. 442.
} 
tendências negativas, aderindo a valores básicos na constituição de seu modo de ser, de forma que a decisão pelo ato delituoso se insira no projeto negativo de vida que escolheu para si mesmo. Esta inafastável definição de si mesmo obriga a que se atente para o exame da culpa na formação da personalidade, dado, contudo, que apenas pode conduzir a uma individualização da pena, pois o cerne da culpabilidade reside na análise da formação da vontade relativa ao ato efetivamente cometido. Repetimos que é inegável que uma ação será tanto mais de alguém, quando mais é adequada à sua personalidade, quanto mais é irrepudiável, posto que negá-la seria negar a si mesmo. $\mathrm{O}$ homem, que decide uma ação e se decide como projeto ao agir, está em situação, sendo sua liberdade de decidir uma liberdade situada, como atmosfera cultural circundante, mas também de circunstâncias mais palpáveis. A formação da escolha da ação, enquanto objeto de um juízo de censurabilidade, não pode pairar em uma instância superior, em que se emite uma decisão prévia, através da qual o núcleo central e espiritual da personalidade decide sobre sua própria existência. Assim, FIGUEIREDO DIAS propõe a culpabilidade 'como violação do dever de conformar sua existência por tal forma que não lese ou ponha em perigo bens jurídico-penais', superando-se desse modo a dificuldade de se ter por base uma autodeterminação indiferente e inverificável. ${ }^{171}$

Outros a relacionam, quase que exclusivamente, com a índole e o caráter do indivíduo.

Nelson Hungria a define como caráter, nos seguintes termos:

Quando se diz personalidade, quer-se dizer, antes de tudo, caráter, síntese das qualidades morais do indivíduo. É a pisque individual no seu modo permanente. $\mathrm{O}$ juiz deve ter em atenção a boa ou má índole do delinqüente, seu modo ordinário, de sentir, de agir ou reagir, a sua maior ou menor irritabilidade, o seu maior ou menor grau de entendimento e senso moral. Deve retraçar-lhe o perfil psíquico. Deve procurar reconhecê-lo no seu temperamento, sua moralité foncière (como diz Saleilles), quer em face do crime, quer fora dêle. É por essa identificação psicológica que se pode apurar a criminosidade do réu ou a sua capacidade de delinqüir, não se devendo, porém, confundir esta com a periculosidade, que é critério para a imposição de medida de segurança (arts. 76, n. II, e 77), de caráter meramente preventivo, e não para fixação da pena, de cunho essencialmente repressivo. Como ensina Petrocelli, a capacidade de delinqüir não é a probabilidade futura de que o réu venha a cometer novos crimes, mas o grau atual de rebeldia contra a lei. A pena não pode ser irrogada pelo que pode acontecer, mas pelo que já realmente aconteceu. ${ }^{172}$

\section{No mesmo sentido Galdino Siqueira dispõe que:}

Personalidade do agente - Esta personalidade pode ser tomada em tríplice aspecto antropológico, psíquico e jurídico. O Código fala em personalidade do agente, sem mais adminículos. Desde que repele a classificação antropológica do criminoso, pela carência de dados adquiridos, como se vê da Exposição de motivos, n. 24, parece que tem em vista o aspecto psicológico. É o que faz o código italiano, sem empregar termo de significação vária, mas o adequado de caráter do réu (art. 123, 1. ${ }^{\circ}$ ). Que

\footnotetext{
${ }^{171}$ Miguel Reale Júnior. Instituições de direito penal: parte geral. $3^{\mathrm{a}}$. ed. Rio de Janeiro: Forense, 2009, p. 407408.

${ }^{172}$ Nelson Hungria. Comentários ao Código Penal. Vol. V. Rio de Janeiro: Forense, 1958, p. 471-472.
} 
também é êsse o sentido em que foi empregada a expressão - personalidade do agente, é o que diz um dos ilustres formuladores do código, explicando que, 'quando se diz, personalidade, quer-se dizer, antes de tudo, caráter, síntese das qualidades morais do indivíduo. É a psique individual no seu modo de ser permanente (797). Entendida a personalidade, segundo a intentio legis, como o caráter do indivíduo, tem o juiz de entrar na difícil, quão delicada averiguação das particularidades físiopsíquicas que individuam e o diferenciam de outros, visando a adaptação completa da pena. Substancialmente, a parte divergências teóricas, o caráter se apresenta como a marca, o cunho pelo qual um homem se distingue dos outros homens, quer se procure a nota diferencial no conjunto das funções intelectivas, voluntárias, sentimentais, quer, segundo Ribot, se tenha em vista restritivamente o conjunto das qualidades afetivas /// e ativas, em todo o caso mergulhando suas raízes no inconsciente, condicionando-se, no que tem de inato, pelo temperamento e pela hereditariedade, e no que tem de adquirido, pelo ambiente e pela educação. ${ }^{173}$

Celso Delmanto, Roberto Delmanto, Roberto Delmanto Junior e Fábio M. de Almeida Demalto também estão entre aqueles que relacionam a personalidade ao caráter, ao assim disporem: "Diz respeito à sua índole, à sua maneira de agir e sentir, ao próprio caráter do agente. Deve-se averiguar se o crime praticado se afina com a individualidade psicológica do agente, caso em que essa sua personalidade voltada ao delito pesará em seu desfavor e, ao contrário, em seu favor" 174 .

Também há controvérsia sobre o que analisar sob o âmbito da personalidade, entendendo Cezar Roberto Bitencourt que "Na análise da personalidade deve-se verificar a sua boa ou má índole sua maior ou menor sensibilidade ético-social, a presença ou não de eventuais desvios de caráter de forma a identificar se o crime constitui um episódio acidental na vida do réu." 175

Referido autor vai além, para incluir, inclusive, neste critério, a análise das eventuais infrações cometidas pelo indivíduo durante a menoridade, já que tecnicamente não poderiam constar de antecedentes criminais, no seguinte sentido: "As infrações criminais praticadas pelo réu durante a menoridade, que, segundo o melhor entendimento, não podem ser admitidas como maus antecedentes, podem servir, contudo, para subsidiar a análise da personalidade do agente, assim como outras infrações criminais praticadas depois do crime objeto do processo em julgamento. Essas duas circunstâncias - infrações penais praticadas durante a menoridade

\footnotetext{
${ }^{173}$ Galdino Siqueira. Tratado de direito penal: parte geral. tomo II. Rio de Janeiro: José Konfino, 1947, p. 780781.

${ }^{174}$ Celso Delmanto et al. Código Penal Comentado. 7. a ed. Rio de Janeiro: Renovar, 2007, p. 188.

${ }^{175}$ Cezar Roberto Bitencourt. Tratado de direito penal: parte geral. São Paulo: Saraiva, 2013, p. 771.
} 
ou depois do crime objeto do cálculo de pena - constituem elementos concretos reveladores da personalidade identificada com o crime, que não podem ser ignorados, embora sejam fundamentais nessa valoração". 176

Há autores, como Lydio Machado Bandeira de Mello, que trabalham o conceito da personalidade, levando em consideração a formação do agente, nos seguintes termos: "São elementos constitutivos ou formadores da personalidade: a idade do réu, o seu desenvolvimento físico e mental, a educação que recebeu, o meio em que foi criado e em que tem vivido, o ter sido ele menor abandonado, o seu grau de instrução ou de cultura, a sua inteligência, a sua sensibilidade, a sua fôrça de vontade, a sua sensibilidade ou insensibilidade moral, o fato de sentir ou não remorso, de mostrar ou não cinismo ou indiferença para com o julgamento moral do próximo a respeito de seu crime, etc" ${ }^{\prime 177}$

Para Ney Moura Teles, o juiz quando da análise da culpabilidade, já estará examinando a personalidade do agente, o que implica inegável bis in idem a sua posterior verificação. Razão pela qual não admite a sua avaliação, exceto se for para levar em conta os aspectos positivos da personalidade.

Se, como se observou, o elemento que fundamenta e limita a pena é a culpabilidade, e se essa é a reprovabilidade do comportamento, de todo óbvio que qualquer conduta é determinada também pela personalidade do homem. Por exemplo: um homem agressivo, que reage ao primeiro impulso, e agride um bem jurídico, tendo plena consciência da proibição, e não se tendo contido, podendo plenamente fazê-lo, será culpado em grau elevado, pelo que realizou e não exatamente por ser dotado de personalidade desequilibrada, violenta. Inegável, entretanto, que, quando o juiz examina a culpabilidade, estará examinando implicitamente a personalidade do agente. Não poderá fazê-lo outra vez, isoladamente, o que seria um verdadeiro bis in idem. $^{178}$

Ney Moura Teles é um dos poucos doutrinadores cujo magistério é pelo afastamento da análise da personalidade, quando negativa, para fins de fixação da pena-base acima do mínimo legal, admitindo a verificação dessa circunstância apenas no viés positivo.

\footnotetext{
${ }^{176}$ Cezar Roberto Bitencourt. Tratado de direito penal: parte geral. São Paulo: Saraiva, 2013, p. 771.

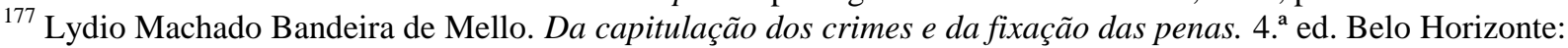
Bernardo Alvares, 1963, p. 123.

${ }^{178}$ Ney Moura Teles. Direito penal: parte geral. São Paulo: Atlas, 2006, p. 366.
} 
Essas circunstâncias, vale repetir, desde que positivas, devem ser levadas em conta no sentido de conduzir a fixação de uma menor pena-base, mas próxima /// do grau mínimo. Se negativas, não poderão fazer a pena-base distanciar-se do mínimo. A doutrina e a jurisprudência não têm tratado essa questão com o cuidado que ela exige. Talvez a insuficiente compreensão da culpabilidade - enquanto juízo de reprovação, puramente normativo - por grande parte dos operadores do direito penal tenha levado a que, na prática, se limitem os juízes, quando da fixação da pena-base, a analisar, isoladamente, cada uma das circunstâncias pessoais - antecedentes conduta social e personalidade - referindo-se aos fatores conhecidos, e, em razão deles, fixando a pena-base, deixando de, como deve ser, aprofundar o exame da culpabilidade, para encontrar seu grau. Talvez seja mesmo, mais fácil, para o juiz, fixar a pena, verificar dois ou mais três fatos antecedentes, uma notícia de mau comportamento social, ou lembrar-se da atitude agressiva do acusado no interrogatório, para encontrar o quantum da pena. Até porque analisar o grau da reprovação - e, principalmente, fundamentar a opção - exige maior atividade intelectual, principalmente na formulação das idéias em sua transposição para o papel. Essas dificuldades, todavia, não podem autorizar a inexistência de qualquer discussão a esse respeito, e tampouco impedir a busca de sua superação. ${ }^{179}$

Ney Moura Teles também acredita que o juiz não tem condições de bem analisar essa circunstância, por falta de capacidade profissional, quando assim dispõe: "O exame da personalidade, de outro lado, não pode ser feito a contento pelo juiz, no âmbito restrito do processo penal, sem o concurso de especialistas - psiquiatras, psicólogos, etc. O magistrado não é formado e preparado para o exame aprofundado de características psíquicas do homem, e permitir-lhe exame apenas superficial, para um desiderato tão grave - perda da liberdade -, seria de uma leviandade inaceitável num ordenamento jurídico democrático e sério. Facultar ao juiz a consideração sobre a personalidade do condenado importa em conceder ao julgador um poder quase divino, de invadir toda a alma do indivíduo, para julgá-la e aplicar-lhe pena pelo que ela é, não pelo que ele, homem, fez. Por isso, ao fixar a pena-base, deve o juiz limitar-se - quanto às circunstâncias judiciais do agente - a examinar em profundidade o grau de culpabilidade - conceito jurídico - do condenado, não se detendo em exames superficiais, incompletos, para os quais nem está preparado, dos antecedentes, da conduta social e da personalidade" 180

Aliás, outro não era o entendimento de Galdino Siqueira, que já se manifestava pela falta de preparo dos juízes, quando dizia que "Nessa intuição, terá o juiz de verificar se o caráter, que estuda, tem suas condições essenciais, de unidade ou coerência de tendências, e a estabilidade ou a própria unidade continuada no tempo e, assim, distinguindo os amorfos, que

\footnotetext{
${ }^{179}$ Ney Moura Teles. Direito penal: parte geral. São Paulo: Atlas, 2006, p. 366-367.

${ }^{180}$ Ney Moura Teles. Direito penal: parte geral. São Paulo: Atlas, 2006, p. 366.
} 
não possuem unidade de forma própria, e os instáveis, alternativamente inertes e explosivos, incertos e desproporcionados na sua reação, agindo da mesma maneira em circunstâncias diferentes e diferentemente em circunstâncias idênticas. Em face de um normal, teria de verificar se era um sensitivo, em que predominava a sensibilidade; um ativo, em que predominava a ação ou um apático, manifestando pouco sentimento e pouca atividade. Todo o expendido mostra que o juiz deve ser especializado em psicologia e psico-patologia, pois só pode recorrer à perícia médico-psiquiátrica quando o caso transcende o normal para o patológico." 181

No mesmo sentido, é o posicionamento de Fernando Galvão Rocha, para quem "A consideração sobre a personalidade alheia, assim, apresenta-se tanto mais difícil quanto falte formação profissional adequada, bem como quando a personalidade do investigado não seja semelhante à personalidade do investigador. A circunstância judicial da personalidade do acusado, dessa forma, manifestamente representa uma análise que, seja pela desinformação de natureza psicológica ou pela distância mantida em relação ao homem comum do povo, supera as forças do magistrado que possa ser considerado 'padrão' em nosso país" ${ }^{182}$

Rogério Greco, enfatizando que a análise dessa circunstância é ofensiva ao direito penal do autor, também refuta a possibilidade de os julgadores fazerem correta aferição da personalidade do agente, por lhes faltar condições técnicas e de conhecimento, no âmbito do processo, uma vez que não é possível um levantamento histórico da vida do réu. $\mathrm{O}$ autor manifesta, inclusive, sua dúvida quanto à efetiva possibilidade de os profissionais de saúde poderem bem analisar essa circunstância judicial.

Acreditamos que o julgador não possui capacidade técnica necessária para a aferição de personalidade do agente, incapaz de ser por ele avaliada sem uma análise detida e apropriada de toda a sua vida, a começar pela infância. Somente os profissionais de saúde (psicólogos, psiquiatras, terapeutas, etc), é que, talvez, tenham condições de avaliar essa circunstância judicial. Dessa forma, entendemos que o juiz não deverá levá-la em consideração no momento da fixação da pena-base. Merece ser frisado, ainda, que a consideração da personalidade é ofensiva ao chamado direito penal do fato, pois que prioriza a análise das características penais do seu autor. ${ }^{183}$

\footnotetext{
${ }^{181}$ Galdino Siqueira. Tratado de direito penal: parte geral. tomo II. Rio de Janeiro: José Konfino, 1947, p. 780781.

${ }^{182}$ Fernando A. N. Galvão da Rocha. Aplicação da pena. Belo Horizonte: Del Rey, 1995, p. 150.

${ }^{183}$ Rogério Greco. Curso de direito penal: parte geral. Niteroi: Impetus, 2008, p. 565.
} 
Amilton Bueno de Carvalho igualmente manifesta-se no sentido de que os juízes não têm habilitação técnica para essa análise, advertindo sobre o caráter retórico das diversas alegações de "personalidade distorcida".

A pena-base tenho que merece ficar no mínimo. A personalidade não por vir contra o apelante porque o cidadão não pode sofrer sancionamento por ela cada um a tem como entende. [...] Mais, a alegação de "personalidade distorcida, com perfil psicológico apropriado aos delitos praticados" é retórica, juízes não tem habilitação técnica para proferir juízos de natureza antropológica, psicológica ou psiquiátrica, não dispondo o processo judicial de elementos hábeis (condições mínimas) para o julgador proferir "diagnósticos" desta natureza. ${ }^{184}$

Alexandre Morais da Rosa, para quem a personalidade é o inimigo secreto, pois quem julga é julgado, diz que:

$\S 21$ - A personalidade: o inimigo secreto. Quem julga, é julgado. 1 - Sobre a 'personalidade' do agente, os julgamentos moralizantes desfilam com todo o vigor. Auto-arvorando-se em censores de toda-a-ordem-moral, a maioria dos magistrados adjetivam muito mais do que democraticamente poderia se esperar. Julgam, enfim, o 'pária' com um desdém demoníaco, em nome da 'segurança jurídica' e do 'bem', obviamente. Apesar de assim procederem, suas pseudoconstatações são o mais puro exercício de imaginação, quiçá um auto-julgamento, projetando no 'outro' seu ‘inimigo interno' (Abreu), sem, ademais, qualquer hipótese comprovada, refutável em contraditório, mas tão-somente impressões pessoais, lugares-comuns, incontroláveis, fascistas. ${ }^{185}$

Conclui sua exposição sobre a personalidade, dizendo que:

Neste espaço ressurge o discurso matreiro da 'Escola Positiva' (Cap. 6o) arraigado
no (in)consciente do um-julgador, onde "eles permanecem vivos, ainda que
vampirescamente refugiados nas próprias tumbas, à espera dos enigmas chocantes-
um maníaco do parque, por exemplo - cujo sangue lhes garantirá mais sobrevida."
Ainda que recentemente tenha sido defenestrada - já vai tarde - a 'opinião
criminológica' tocaia o acusado, irrompendo neste momento da aplicação da pena.
Lá está ela, a 'personalidade', o acusado, sendo julgado arbitrariamente. Em face da
série de condicionantes anteriormente construídas, dependendo dos fatores pessoais
do um-juiz, será manejada retoricamente para aumentar a pena, partindo-se da lógica
de que o criminoso é um 'doente moral' e, como tal, a pena seria seu 'tratamento' -

${ }^{184}$ Amilton Bueno de Carvalho. Personalidade não pode prejudicar cidadão. Atenuantes podem deixar a pena abaixo do mínimo. Prescritibilidade da medida de segurança. Boletim IBCCRIM, São Paulo, n.129, Agost., 2003.

185 Alexandre Morais da Rosa. Decisão no Processo Penal como Bricolagem de Significantes. Tese de Doutoramento apresentada à Universidade Federal do Paraná, em 2004, p. 351. (Destaques do autor). 
ela pode curar - e o juiz é o legitimado para aplicar a salvação, no eterno: "jogo do culpado e do pastor, onde opera simbolicamente uma cena de sacrificio." ${ }^{\text {"186 }}$

Fernando José da Costa e Paulo José da Costa entendem que não é possível desvincular a análise da personalidade de sua conduta social. E manifestam-se no seguinte sentido:

\begin{abstract}
A personalidade está intimamente ligada à conduta. Em função dela, poderá o juiz exacerbar ou atenuar a pena. Se revelar personalidade de acentuada indiferença afetiva, de analgesia moral, haverá exacerbação da reprimenda imposta. Se não revelar traços de agressividade, mostrando tratar-se de meliante que visa ao lucro sem ostentar a brutalidade, ser-lhe-á concedido um tratamento mais benigno. Deverá o magistrado 'ter em atenção a boa ou má índole do delinqüente, seu modo ordinário de sentir, de reagir, sua maior ou menor irritabilidade e o seu maior ou menor grau de entendimento (JTACrim, 39:167). A personalidade, para ser valorada em seu aspecto dinâmico e global, considerando o agente em seu meio social circundante ocasional ou permanente, que o pressiona e o faz reagir de forma passiva ou agressiva, não pode ser analisada isoladamente, destacada da conduta social. ${ }^{187}$
\end{abstract}

André Stefam, assim como na análise da conduta social, entende que a pena não pode ser aumentada com base na pessoa do réu, mas sim pela gravidade de seu ato. E seria levada em consideração apenas se tivesse alguma relação com o tipo de crime praticado.

Trata-se de seu perfil psicológico (ex.: personalidade voltada para o crime, bom ou mau caráter etc.). Cabe aqui a mesma ressalva feita no item acima, isto é, devem-se analisar com cautela os dados indicativos da personalidade do agente, para que não balize a pena com base, exclusivamente, na pessoa do réu. Este deve ser punido pela gravidade do ato que cometeu e não pela boa ou má pessoa que seja. Por exemplo: se o réu comprovadamente possui uma personalidade acentuadamente erotizada, relevando depravamento sexual, esse fator poderá ser validamente ponderado se ele for condenado por crime de estupro (CP, art. 213); jamais num processo por estelionato, pois a característica nada teria a ver com o ilícito cometido ${ }^{188}$.

Alvino Augusto de Sá, em parecer ${ }^{189}$ ofertado sobre a sentença condenatória de E.P.A.T, a noventa e quatro anos e seis meses de reclusão, abordou exclusivamente a personalidade da ré, como circunstância judicial prevista no artigo 59, para fins de

\footnotetext{
186 Alexandre Morais da Rosa. Decisão no Processo Penal como Bricolagem de Significantes. Tese de Doutoramento apresentada à Universidade Federal do Paraná, em 2004, p. 353. (Destaques do autor).

${ }^{187}$ Fernando José da Costa e Paulo José da Costa Júnior. Curso de direito penal. 12. ${ }^{\text {a }}$ ed. São Paulo: Saraiva, 2010, p. 246.

${ }^{188}$ André Stefam. Direito penal. 1. São Paulo: Saraiva, 2010, p. 342.

${ }^{189}$ Alvino Augusto de Sá. Parecer sobre a sentença condenatória de E.P.A.T. (Este parecer não foi publicado. Foi disponibilizado pelo autor, por email em 07/10/2012, com expressa autorização para utilização, nesse trabalho).
} 
individualização e fixação da pena base, por ter sido tomada pela magistrada sentenciante como "voltada integralmente para o crime".

Com efeito, em referido Parecer, o autor traz diversos entendimentos doutrinários sobre o tema, havendo uns que admitem a avaliação da personalidade do réu pelos juízes, outros que a rechaçam por completo, e alguns que a admitem, porém com ressalvas.

Concluindo a exposição doutrinária, Alvino Augusto de Sá apresenta síntese da posição dos autores, de acordo com os seguintes tópicos: 1) o que os autores entendem por personalidade; 2) o que deve aferir na personalidade do agente, os dados que devem nortear e fundamentar a avaliação e motivar a decisão do juiz; 3) a questão do preparo do juiz para avaliar a personalidade; e 4) a avaliação da personalidade e o direito penal do autor.

Por personalidade, os autores citados por Alvino, em seu Parecer, têm o seguinte entendimento: "Personalidade é o conjunto de caracteres exclusivos de cada indivíduo, é o núcleo de sua individualidade, de sua originalidade. A personalidade do agente é característica individual, sendo assim temerário avaliar os co-réus como tendo personalidades idênticas. Ela é o retrato psíquico do agente, refere-se à sua índole, à sua maneira de agir e sentir, ao seu próprio caráter. Ela não é estática, mas está em constante interação com o meio, sendo o crime produto dessa interação. Por outro lado, numa compreensão algo diversa, a personalidade é entendida como se referindo ao conjunto de qualidades morais do indivíduo, aos padrões de moralidade e de honestidade."190

No aspecto daquilo que deve ser considerado para se aferir a personalidade do agente, Alvino sumarizou o pensamento dos autores da seguinte forma: "O juiz, na apreciação da personalidade do réu, deverá levar em conta dados concretos, objetivos, relativos à sua conduta geral: vida familiar, comunitária, escolar, social, profissional. A avaliação da personalidade do réu tem como objeto, não suas qualidades morais, mas sua capacidade para delinquir. (Em compreensão diversa, há quem entenda que se deve procurar aferir padrões de honestidade, relacionados aos critérios de moralidade). São aspectos negativos da personalidade a serem levados em conta: agressividade, insensibilidade acentuada, emotividade desequilibrada, passionalidade exacerbada, maldade, irresponsabilidade no

\footnotetext{
${ }^{190}$ Alvino Augusto de Sá. Parecer sobre a sentença condenatória de E.P.A.T., p. 14. (Este parecer não foi publicado. Foi disponibilizado pelo autor, por email em 07/10/2012, com expressa autorização para utilização, nesse trabalho).
} 
cumprimento das obrigações, ambição desenfreada, soberba inveja, intolerância, perversidade. Outros aspectos a serem valorados: comportamento delinquente durante a menoridade e uso de intensa violência na perpetração do crime. Em todo caso, há quem alerte para o fato de que não existe um caráter, um tipo ou uma constituição que sejam típicos do criminoso, que o predisponham à prática criminosa. Por outro lado, deve-se também avaliar as características positivas da personalidade, tais como persistência, responsabilidade nos afazeres, coragem, e maturidade. Além disso, sem que se pretenda nenhuma indulgência especial por parte do juiz para com privilegiados, há que se levar em conta até mesmo o valor social do agente, a saber, seu grau de ascendência social, prestígio pessoal, prestígio profissional, pois tudo isso é expressão de seus méritos pessoais. Muitos autores enfatizam a idéia de o julgador deve evitar apelar para afirmações vagas, superficiais, fórmulas estereotipadas e "preguiçosas" (expressão de Costa Júnior), expressões de uma "falsa retórica da personalidade" (Alves), resultantes de uma valoração arbitrária, superficial, preconceituosa e aplicáveis a múltiplos casos. São citados como exemplos dessas expressões e afirmações: personalidade deturpada ou voltada ao crime, personalidade desajustada, personalidade agressiva, personalidade impulsiva, personalidade voltada para práticas delitiva, personalidade desvirtuada, personalidade desviada, personalidade comprometida pela falta de valores éticos e morais. As expressões estereotipadas acarretam uma rotulação dos indivíduos e a redução de suas peculiaridades, em flagrante contramão da individualização."191

No quesito preparo do juiz para avaliar a personalidade, Alvino fez os seguintes apontamentos: "Segundo alguns autores, o juiz não tem necessidade de recorrer à assessoria de outros profissionais, como psicólogo, psiquiatra, para fazer a avaliação da personalidade, ou até mesmo nem é conveniente que o faça, tratando-se de prerrogativa sua. No entanto, mesmo reconhecendo ter o juiz condição de proceder a essa avaliação, há quem reconheça eventual necessidade dele recorrer a um exame técnico, especializado. A maioria dos autores, porém, entende que o juiz não domina os conceitos e conhecimentos da psicologia e psiquiatria, não tem condições de fazer uma avaliação científica da personalidade do criminoso e pode se deixar levar por uma valoração superficial e preconceituosa (o que o conduziria às tais

\footnotetext{
191 Alvino Augusto de Sá. Parecer sobre a sentença condenatória de E.P.A.T., p. 14-15. (Este parecer não foi publicado. Foi disponibilizado pelo autor, por email em 07/10/2012, com expressa autorização para utilização, nesse trabalho).
} 
expressões estereotipadas de que se falou acima). A personalidade é um conceito que deve ser explorado, analisado e compreendido nas áreas da psicologia, psiquiatria e antropologia." 192

Por fim, quanto à avaliação da personalidade e o direito penal do autor, aponta que “diversos autores alertam para o risco do juiz, ao proceder à avaliação da personalidade, acabar se deixando guiar pela culpabilidade do autor, em detrimento da culpabilidade do ato, e regredir do direito penal do ato para o direito penal do autor, o que facilmente o remeteria ao direito penal do inimigo."193

Alvino, em seu parecer, dispõe que:

É nosso entendimento, todavia, que nenhum diagnóstico criminológico nos permitirá dizer que determinada personalidade está integralmente voltada para o crime. Sequer das personalidades psicopáticas poder-se-ia afirmar tal coisa, mesmo porque existem psicopatas não produtivos criminalmente, ainda que sempre se caracterizem por serem antissociais. Talvez se possa afirmar que determinada pessoa, em certo momento de sua vida, encontra-se (integralmente?) voltada para o crime, dentro de um contexto de avaliação de sua conduta social. Mas isto não nos permite, de forma absolutamente alguma, do ponto de vista da psicologia e psiquiatria, concluir que sua personalidade está (integralmente) voltada para o crime, pois estaríamos passando indevidamente de uma avaliação pontual da conduta social para uma avaliação psicológica, para uma avaliação de personalidade, de caráter. Esta exige um olhar muito mais profundo e tecnicamente acurado, com fundamentos e justificativas que vão muito além das que são necessárias para a avaliação da conduta social. Repita-se e frise-se: personalidade voltada (integralmente) para o crime é uma coisa; pessoa voltada (integralmente) para o crime (a partir de certa época de sua vida) é outra coisa bem diversa. A primeira hipótese refere-se à circunstância judicial personalidade. A segunda não pode jamais ser lavada em conta na avaliação da circunstância judicial personalidade, mas na avaliação da circunstância judicial conduta sócia. ${ }^{194}$

Poderíamos continuar pontuando o entendimento de outros autores jurídicos sobre o conceito de personalidade, o que engloba, e, por fim, a possibilidade de os juízes a analisarem de forma eficaz.

\footnotetext{
${ }^{192}$ Alvino Augusto de Sá. Parecer sobre a sentença condenatória de E.P.A.T., p. 15-16. (Este parecer não foi publicado. Foi disponibilizado pelo autor, por email em 07/10/2012, com expressa autorização para utilização, nesse trabalho).

${ }^{193}$ Alvino Augusto de Sá. Parecer sobre a sentença condenatória de E.P.A.T., p. 16. (Este parecer não foi publicado. Foi disponibilizado pelo autor, por email em 07/10/2012, com expressa autorização para utilização, nesse trabalho). (Destaques do autor).

${ }^{194}$ Alvino Augusto de Sá. Parecer sobre a sentença condenatória de E.P.A.T., p. 19. (Este parecer não foi publicado. Foi disponibilizado pelo autor, por email em 07/10/2012, com expressa autorização para utilização, nesse trabalho). (Destaques do autor).
} 
No entanto, entendemos que os posicionamentos já colocados bem expressam o pensamento que permeia o significado de personalidade, para fins de aplicação da pena.

Renova-se, nesta oportunidade, a argumentação desenvolvida no item 2.4, em relação à conduta social, no sentido de que, no âmbito do processo penal, as poucas oportunidades, em que seria possível perquirir sobre a personalidade do agente - interrogatório e oitiva de testemunhas - esta investigação não é feita de forma exitosa.

Então, seja por acreditar na completa impossibilidade de aferir esta circunstância judicial, do ponto de vista técnico, seja por entender que não há interesse de sua real avaliação, na prática, seja, por fim, por verificar que sua manutenção no artigo 59 do Código Penal acarreta julgamento moral do agente, penalizando seu "ser", mais que seu agir, é que julgamos pelo necessário afastamento desta circunstância judicial do ordenamento jurídico.

Aliás, esse é o entendimento constante no último Relatório, de 10/12/2013, do Senador Pedro Taques sobre o Projeto de Alteração do Código Penal (236/12), no qual o artigo $73^{195}$, substituindo o atual artigo 59, exclui a conduta social e a personalidade do dispositivo legal.

No próximo capítulo, serão tratados os conceitos de conduta social e personalidade na Jurisprudência Pátria, passando-se pela análise da Súmula 444 do Superior Tribunal de Justiça, que funcionou como divisor de águas daquilo que se levava em conta para a aferição dessas circunstâncias judiciais pessoais.

\section{5 “Circunstâncias judiciais}

Art. 73. O juiz, atendendo à culpabilidade, aos motivos e fins, aos meios e modo de execução, às circunstâncias e consequências do crime, bem como eventual contribuição da vítima para o fato, estabelecerá, conforme seja necessário e suficiente para reprovação e prevenção do crime:

I - as penas aplicáveis dentre as cominadas;

II - a quantidade de pena aplicável, dentro dos limites previstos;

III - o regime inicial de cumprimento da pena de prisão;

IV - a substituição da pena de prisão aplicada por outra espécie de pena, se cabível.

$\S 1^{\circ} \mathrm{Na}$ análise das consequências do crime, o juiz observará especialmente os danos suportados pela vítima e seus familiares, se previsíveis.

$\S 2^{\circ}$ Não serão consideradas circunstâncias judiciais as elementares do crime ou as circunstâncias que devam incidir nas demais etapas da dosimetria da pena." Disponível em: $\langle$ http://www.pedrotaquesmt.com.br/uploads/downloads/Relatorio-Novo-Codigo-Penal-10-12-13.pdf $>$. Acesso em: 11 dez. 2013. 


\section{Análise de julgados sobre antecedentes, conduta social e personalidade na Jurisprudência Brasileira}

\subsection{Análise da Súmula 444 do Superior Tribunal de Justiça}

Em virtude de a pesquisa, de certa forma, abranger o estudo da manutenção dos antecedentes como condição para aumento da pena-base, na fixação da reprimenda, imperiosa a análise da Súmula 444 do Superior Tribunal de Justiça, editada em 28/04/2010, cuja publicação no DJE ocorreu em 13/05/2010, por ter pacificado o entendimento do que não pode ser levado, negativamente, em conta para agravar a pena-base.

Enuncia a Súmula 444 que "É vedada a utilização de inquéritos policiais e ações penais em curso para agravar a pena-base."

Para sua edição, o Superior Tribunal de Justiça considerou nove julgamentos precedentes. São eles o HC 81866/DF 2007/0092884-0, j. 25/9/2007 (DJ 15/10/2007); HC 96670/DF 2007/0297509-4, j. 15/12/2009 (DJe 08/02/2010); HC 97857/SP 2007/0310354-7, j. 21/10/2008 (DJe 10/11/2008); HC 106089/MS 2008/0100443-9, j. 03/11/2009 (DJe 30/11/2009); HC 128800/MS 2009/0028469-0, j. 15/12/2009 (DJe 22/02/2010); HC 142241/RJ 2009/0139174-7, j. 15/12/2009 (DJe 01/02/2010); HC 150266/MS 2009/01996087, j. 19/11/2009 (DJe 07/12/2009); REsp 730352/RS 2005/0034133-5, j. 29/09/2009 (DJe 19/10/2009); e REsp 898854/PR 2006/0224582-9, j. 22/05/2007 (DJ 29/06/2007).

Analisando cada precedente, conclui-se que a Súmula, ao mencionar que inquéritos policiais e ações penais em andamento não devem ser considerados para agravar a pena-base, não restringe a abordagem somente à análise dos antecedentes, estendendo o entendimento também à impossibilidade de transferir tais apontamentos para conduta social e personalidade do agente.

Para evitar distorcidas aplicações, até porque um dos precedentes é controverso, como se verificará a seguir, acredita-se que a Súmula deveria ter sido bem explícita, dispondo de forma taxativa sobre a impossibilidade de utilização de inquéritos, ações penais em curso, e 
condenações sem trânsito em julgado, na análise de antecedentes, conduta social, ou personalidade.

Importante essa ponderação, em virtude de o REsp 898.854/PR (2006/0224582-9), julgado em 22/05/2007, ter sido alçado à condição de precedente, inexplicavelmente, uma vez que demonstra total incongruência com o constante dos demais precedentes, e com o espírito que norteou a criação desta Súmula, que primou pela consagração do princípio da presunção de inocência.

De fato, tal julgado demonstra a incoerência na avaliação dos apontamentos constantes da folha de antecedentes do "réu", na medida em que a Quinta Turma deu, por unanimidade, provimento a Recurso Especial do Ministério Público, para cassar acórdão do Tribunal "a quo", com o fim de restabelecer a sentença de primeiro grau, que aumentou a pena-base, considerando o registro de antecedentes do "menor" como mácula à conduta social e personalidade.

\begin{abstract}
O entendimento pacificado neste Superior Tribunal de Justiça, de fato, é no sentido de que a existência de inquéritos ou ações penais em andamento não maculam o réu como portador de maus antecedentes, suficientes para, na análise das circunstâncias do art. 59 do CP, isoladamente, aumentar a pena-base acima do mínimo legal. Ocorre que, conforme já referido, o magistrado singular não valorou as ações penais em andamento a título de maus antecedentes criminais, mas como fatos que maculavam a personalidade e sua conduta social do réu. Sendo assim, não se vislumbra qualquer incorreção da dosimetria efetuada em primeiro grau, razão pela qual a mesma merece ser restabelecida, cassando-se o acórdão a quo. ${ }^{196}$
\end{abstract}

O precedente, ao invés de referendar entendimento de que os apontamentos no histórico do condenado, à época em que era menor de idade, não poderiam ser avaliados como antecedentes, visto não o serem tecnicamente, e nem aproveitados para desvalorizar a conduta social e/ou personalidade, na verdade, veio, na contramão, enunciar que ditos apontamentos podem ser considerados, no âmbito do artigo 59 do Código Penal, na avaliação negativa da conduta social e/ou personalidade do agente. O que revela inconcebível ter servido de precedente à Súmula 444, esta sim de caráter genérico, a demonstrar que a extensão dos apontamentos alcança as demais circunstâncias judiciais.

${ }^{196}$ Resp. 898.854/PR, Relator Ministro Gilson Dipp, $5^{\text {a }}$ Turma, j. 22/5/2007, DJ 29/06/2007. 
Já o precedente consistente no HC 81.866/DF (2007/0092884-0), julgado em 25/09/2007, também pela Quinta Turma, em sua ementa, estatui que:

Inquéritos policiais e ações penais em andamento não constituem maus antecedentes, má conduta social nem personalidade desajustada, porquanto ainda não se tem contra o réu um título executivo definitivo. 3. Os atos infracionais praticados durante a adolescência do acusado não podem ser considerados como geradores de antecedentes, nem de personalidade desajustada.

Em seu voto, a Ministra Relatora Jane Silva (Desembargadora convocada do TJ/MG) diz que:

Após a Constituição da República de 1988, antecedentes devem resultar de decisão condenatória transitada em julgado, sendo que processos em andamento, ou inquéritos não podem servir para agravar a pena do réu, nem mesmo para se considerar que ele possui má conduta social, ou personalidade deformada, porquanto poderá, no final dos processos, ser absolvido. A condenação só produz qualquer efeito, em relação ao apenado, após o seu trânsito em julgado, sendo abundante a jurisprudência neste sentido, tanto do Supremo Tribunal Federal, como deste Sodalício. $^{197}$

E conclui que "a pena deve ser refeita para se desconsiderar os antecedentes com base em processos em andamento e a personalidade desajustada fundada em atos infracionais."

Ambos precedentes retro mencionados foram julgados por unanimidade, pela Quinta Turma, por praticamente os mesmos Ministros (Felix Fischer, Laurita Vaz, Arnaldo Esteves Lima), excetuando-se que, no segundo, também julgou o Ministro Napoleão Nunes Maia Filho. Os relatores foram diferentes. No primeiro caso o relator foi o Ministro Gilson Dipp, enquanto, no segundo, a Ministra Jane Silva (Desembargadora Convocada do TJ/MG).

Será que os quatro meses transcorridos entre os dois julgamentos e a alteração da relatoria contribuíram para a alteração de entendimento?

Pois, a partir de então, os demais precedentes, mesmo sem uniformidade quanto ao entendimento da vedação de inquéritos policiais e ações penais em curso, para configurar maus antecedentes, má conduta social e personalidade desajustada, em função de ainda não se

\footnotetext{
${ }^{197}$ HC 81866/DF, Relatora Ministra Jane Silva (Desembargadora Convocada do TJ/MG), $5^{\text {a }}$ Turma, j. 25/9/2007, DJ 15/10/2007.
} 
ter um título executivo penal definitivo, jamais retrocederam para considerar aquilo que não pode ser considerado tecnicamente como antecedente na avaliação negativa da conduta social ou personalidade.

Como se constatará abaixo, os precedentes ora englobam os impedimentos à análise dos antecedentes, ora à verificação de antecedentes e conduta social, e ora tratam destes e da personalidade, o que valida a ideia inicial de que para afastar aplicações equivocadas, a Súmula deveria ter enunciado, de forma enfática, a proibição da avaliação de inquéritos, ações penais em andamento, sentenças condenatórias sem trânsito em julgado, e também apontamentos de atos infracionais, à análise dos antecedentes, conduta social e personalidade do agente, não podendo fundamentar, em nenhuma hipótese, o aumento da pena-base.

Vê-se que no HC 97857/SP (2007/0310354-7), julgado em 21/10/2008, em sua ementa lê-se que "4. Em obediência ao princípio constitucional da presunção de inocência, ações penais em curso não podem ser tidas como maus antecedentes." ${ }^{198}$, demonstrando que o impedimento se restringiria apenas à análise dos antecedentes.

Já do precedente consistente no Resp 730352/RS (2005/0034133-5), julgado em 29/09/2009, se verifica, nos termos do voto da Ministra Relatora Maria Thereza de Assis Moura, a extensão da vedação do computo de inquéritos e processos em curso também à análise da conduta social e personalidade.

De fato, entendeu a Corte de origem, acerca do primeiro ponto, que os maus antecedentes a partir de processos em curso não poderiam prevalecer para aumentar a pena base. Este o posicionamento desta Corte, que tem destacado que inquéritos e processos judiciais em curso não sejam tidos como maus antecedentes, assim também que não sirvam para valorar negativamente a conduta social ou a personalidade do agente, sendo preferível a fixação da pena-base no mínimo legal. ${ }^{199}$

O HC 106089/MS, precedente julgado em 03/11/2009, por sua vez, restringe a extensão da avaliação dos inquéritos e ações penais em curso somente aos antecedentes e conduta social, quando, consoante sua ementa diz que "2. Conforme orientação há muito firmada nesta Corte de Justiça, inquéritos policiais, ou mesmo ações penais em curso, não

\footnotetext{
${ }^{198}$ HC 97857/SP, Relator Ministro Og Fernandes, 6a Turma, j. 21/10/2008, DJe 10/11/2008.

${ }^{199}$ Resp 730352/RS, Relatora Ministra Maria Thereza de Assis Moura, 6a Turma, j. 29/9/2009, DJe 19/10/2009.
} 
podem ser considerados como maus antecedentes ou má conduta social para exacerbar a penabase ou fixar regime mais gravoso.",200

Vê-se que nem mesmo os precedentes que deram origem à promulgação da Súmula pela Terceira Turma do Superior Tribunal de Justiça são uniformes quanto ao que será objeto de exclusão para fins de aumento da pena-base. Há julgados em que se estende o conceito também à análise da personalidade, enquanto outros se limitam à conduta social. Todos são unânimes, no entanto, quanto à impossibilidade de mensurá-los como maus antecedentes.

E tal conclusão fica clara também da verificação do precedente constante do HC 150266/MS (2009/0199608-7), cuja ementa dispõe que "2. É pacífica a jurisprudência desta Corte no sentido de ser vedada a utilização de processos e inquéritos em andamento para a caracterização de maus antecedentes.",201

O precedente consistente no HC 142241/RJ (2009/0139174-7), julgado em 15/12/2009, não só estipula que os inquéritos e ações penais em curso não servem para valorar negativamente os antecedentes, a conduta social e a personalidade do agente, nos termos de sua ementa, como vai além, citando entendimento do eminente Ministro Felix Fischer em outro julgamento, quando assevera que:

A personalidade do paciente, por sua vez, foi considerada desfavorável, ao argumento de que é "inclinada para a prática delitiva" (fl. 149). Ocorre que é lamentável que a personalidade ainda conste do rol das circunstâncias judiciais do art. 59, do CP, pois se trata, na verdade, de resquício do Direito Penal de Autor. Além do mais, dificilmente constam dos autos elementos suficientes para que o julgador (que, de regra, não é psiquiatra e nem psicólogo - não sendo, portanto, expert) possa chegar a uma conclusão cientificamente sustentável. Por conseguinte, não havendo dados suficientes para a aferição da personalidade do agente, mostra-se incorreta sua valoração negativa a fim de supedanear o aumento da pena-base. (HC 137.995/MS, Quinta Turma, DJe 13/10/09). ${ }^{202}$

Tal precedente, mais abrangente que os demais, dispõe com clareza que também a personalidade não pode ser negativamente considerada em função da existência de apontamentos na vida pregressa do sujeito. Sendo importante ressaltar o entendimento

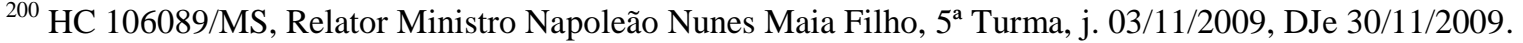

${ }^{201}$ HC 150266/MS, Relator Ministro Haroldo Rodrigues (Desembargador Convocado do TJ/CE), 6 ${ }^{\text {a }}$ Turma, j. 19/11/2009, DJe 07/12/2009.

${ }^{202}$ HC 142241/RJ, Relator Ministro Arnaldo Esteves Lima, 5a Turma, j. 15/12/2009, DJe 01/02/2010.
} 
desposado pelo Ministro Felix Fischer de que é resquício de direito penal de autor a mantença deste critério como condição de aumento da pena, e a dificuldade de encontrar nos autos dados suficientes, que permitam ao juiz, que não detém capacidade técnica, analisar a personalidade de alguém.

E no HC 96670/DF (2007/0297509-4), julgado em 15/12/2009, em sua ementa lê-se que "1. Conforme entendimento desta Corte, inquéritos policiais e ações penais em andamento não podem ser utilizados como fundamento para majoração da pena-base, a título de maus antecedentes, má conduta social e personalidade voltada para o crime."

Em seu voto a Ministra Relatora Laurita Vaz diz que "A análise das circunstancias judiciais, mormente quanto à conduta social e à personalidade do agente, está a merecer reparos. Destarte, conforme entendimento desta Corte, inquéritos policiais e ações penais em andamento não podem ser utilizados como fundamento para majoração da pena-base, a título de maus antecedentes, má conduta social e personalidade voltada ao crime."203

Finalmente, o último precedente, HC 128800/MS (2009/0028469-0), julgado em $15 / 12 / 2009$, muito embora diga que inquéritos e ações penais em andamento não possam ser considerados como maus antecedentes para aumento da pena, na sequência, de forma indireta, também referenda a extensão do entendimento à análise da personalidade, ao dispor que não há elementos para aferir a personalidade do agente, demonstrando a impossibilidade da transferência de tais apontamentos à análise da personalidade.

IV - In casu, verifica-se que a r. decisão de primeiro grau apresenta em sua fundamentação incerteza denotativa ou vagueza, carecendo, na fixação da resposta penal, de fundamentação objetiva imprescindível, utilizando-se, entre outras, de expressões como: "culpabilidade intensa", "conduta socialmente censurável", "motivos egoísticos" e "circunstâncias e conseqüências que causam abalo social". Dessa forma, não existem argumentos suficientes a justificar, no caso concreto, a exacerbação da reprimenda. V - Inquéritos e ações penais em andamento, por si, não podem ser considerados como maus antecedentes, para fins de exacerbação da penabase ou, consequentemente, para a fixação de regime inicial de cumprimento de pena mais gravoso (Precedentes desta Corte e do Pretório Excelso). VI - Não havendo elementos suficientes para a aferição da personalidade do agente, mostra-se incorreta

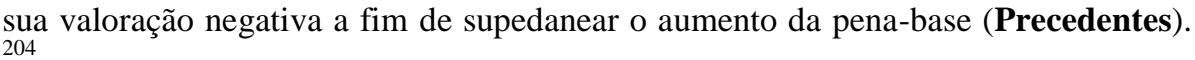

\footnotetext{
${ }^{203}$ HC 96670/DF, Relatora Ministra Laurita Vaz, 5 a Turma, j. 15/12/2009, DJe 08/02/2010.

${ }^{204}$ HC 128800/MS, Relator Ministro Felix Fischer, $5^{\text {a }}$ Turma, j. 15/12/2009, DJe 22/02/2010.
} 
Por observar que os precedentes originários da Súmula 444 não são uníssonos, entendemos importante a análise dos julgados havidos, após a edição da Súmula, a fim de averiguar qual entendimento e extensão lhe têm sido conferidos.

\subsection{Análise do impacto da Súmula 444 do STJ nas decisões do Superior Tribunal de Justiça, Tribunal Regional Federal da $3^{\text {a }}$ Região de São Paulo e Tribunal de Justiça do Estado de São Paulo.}

\subsubsection{Decisões do Superior Tribunal de Justiça}

A referida pesquisa dos julgados foi efetuada segundo os seguintes critérios. Primeiro, analisou-se como o próprio Superior Tribunal de Justiça se comportou após a edição da Súmula 444. Para tal fim, a pesquisa foi efetuada, no dia 27/03/2012, no sitio eletrônico do STJ www.stj.gov.br, e no Campo Jurisprudência, as palavras chaves pesquisadas foram "Aplicação da Súmula 444 STJ".

O filtro apontou 57 (cinqüenta e sete) julgados. Descartaram-se 12 (doze), porque não tinham qualquer relação com o assunto pesquisado, ou porque julgados antes da edição da Súmula.

Os 45 (quarenta e cinco) casos analisados demonstraram que a Súmula 444 tem caráter genérico, proibindo a análise de inquéritos policiais, ações penais em andamento e condenações sem trânsito em julgado para mal avaliar antecedentes, conduta social e personalidade do agente.

Os casos analisados plasmaram o entendimento de a conduta social e a personalidade do sujeito não serem maculadas pela presença de apontamentos na ficha de antecedentes, caso não sirvam para caracterizá-los tecnicamente.

A reforma dos julgamentos efetuada pelo Superior Tribunal de Justiça baseia-se na soberania do princípio da presunção de não culpabilidade, do estado de inocência. 
Em virtude de a análise dos julgados editados pelo Superior Tribunal de Justiça pós Súmula 444 ter demonstrado, de forma cabal, o caráter genérico de seu enunciado, abarcando, portanto, a vedação de se computar a presença de inquéritos policiais e ações penais em andamento tanto na análise do critério antecedentes, como nos critérios conduta social e personalidade, passamos para uma segunda fase da pesquisa jurisprudencial, analisando os julgados do Tribunal Regional Federal da $3^{\text {a }}$ Região e Tribunal de Justiça do Estado de São Paulo.

A escolha dos Tribunais paulistas foi feita, em função de abarcar os julgamentos que envolvem o Estado mais populoso do país.

O objetivo deste levantamento jurisprudencial em sede dos Tribunais de São Paulo, em âmbito Estadual e Federal, é verificar, primeiramente, se os desembargadores acataram integralmente a Súmula 444 do Superior Tribunal de Justiça, aplicando o entendimento; e em segundo lugar, se os magistrados de primeiro grau julgam contrariamente à Súmula ou se as reformas dos julgados nos Tribunais ocorreram após sua edição.

A pesquisa nesta fase, portanto, deverá responder aos questionamentos abaixo. Primeiro dirigido aos desembargadores, e depois aos magistrados de primeiro grau, se for permitida a inferência da resposta nos acórdãos pesquisados.

Desembargadores.

1) Os desembargadores aplicam a Súmula 444 do STJ?

2) Qual a extensão que lhe é conferida? A) antecedentes; B) conduta social ou C) personalidade.

3) Não aplicam a Súmula, sob qual fundamento?

Juízes de Primeiro Grau 
1) Quantos julgamentos de primeiro grau ocorreram antes da edição da Súmula 444 do STJ?

2) Nos julgamentos havidos anteriormente à Súmula, o fundamento do aumento da penabase foi antecedentes, considerando-se, equivocadamente, inquéritos policiais, ações em andamento, sentenças condenatórias sem trânsito em julgado e até atos infracionais? 2.1) Foi conduta social? 2.2) Personalidade do agente?

3) Após a edição da Súmula, os magistrados de primeiro grau a aplicaram?

\subsubsection{Decisões do Tribunal Regional Federal da $3^{\text {a }}$ Região}

A pesquisa foi efetuada, inicialmente, pelo Tribunal Regional Federal da $3^{\text {a }}$ Região, por meio de seu sitio eletrônico www.trf3.jus.br, no ícone Jurisprudência, no Campo Pesquisa Livre, com as seguintes palavras-chave "Aplicação da Súmula 444 do STJ". A data da realização da pesquisa foi 03/04/2012.

O filtro trouxe 125 (cento e vinte e cinco) julgados, sendo o mais recente a Apelação Criminal no 0000431-62.2001.4.03.6181/SP, julgada em 26/03/2012, pela $5^{\text {a }}$ Turma, sob a relatoria da Desembargadora Federal Ramza Tartuce.

É importante esta ponderação para que se firme o corte da pesquisa, que terá como limite máximo o julgamento retro mencionado.

Releva mencionar que a verificação dos julgados não teve finalidade de avaliar a aplicação da Súmula, como caráter vinculante, ou a quantidade de julgados que a aplicaram, de forma a traçar um estudo estatístico. Mesmo que se fale em números, quer-se deixar claro que não se objetiva um estudo quantitativo, mas sim exemplificativo, que permita, dentro do universo pesquisado, tirar algumas conclusões, para responder aos questionamentos já ponderados acima, se possível.

A análise dos 125 (cento e vinte e cinco) acórdãos revelou que o Tribunal Federal Regional da $3^{\text {a }}$ Região, na sua esmagadora maioria, acatou a Súmula 444 do STJ, uma vez que, em 90 (noventa) dos casos julgados, houve sua aplicação. Sendo importante dizer que dos 125 , 
17 não guardam qualquer relação com a Súmula, seja porque são referentes a casos cíveis e tributários, seja porque julgados em datas anteriores à edição da Súmula.

A observância da Súmula nem sempre implicou redução da pena. Houve casos em que a sanção se manteve acima do mínimo legal, em função de outras peculiaridades, como nos dois exemplos abaixo.

De fato, na Apelação Criminal 0000786-97.2010.4.03.6006/MS, de relatoria do Desembargador Federal José Lunardelli, da $1^{\text {a }}$ Turma, julgada em 20/03/2012, em que se apurou o crime de contrabando, o Tribunal reformou a sentença de primeiro grau, para afastar os antecedentes analisados contrariamente à Súmula 444 do STJ, mantendo, no entanto, a pena acima do mínimo legal, pela expressiva quantidade de cigarros apreendidos ${ }^{205}$.

3. DA DOSIMETRIA. A pena-base foi fixada acima do patamar mínimo, em 1 (um) ano e 4 (quatro) meses de reclusão, em regime aberto, ao argumento de que o réu possui maus antecedentes, tendo em vista que já respondeu pelo crime de descaminho/contrabando, conforme consta da ação penal $n^{\circ}$ 000093772.2010.403.6003, em trâmite na Subseção Judiciária de Três Lagoas/MS. No entanto, observo que não há nos autos prova de que o acusado possui condenação com trânsito em julgado e a culpabilidade e as consequências dos delitos são as normais à espécie. Assim, nos moldes da Súmula 444 do Superior Tribunal de Justiça cuja aplicabilidade restou salientada pela $1^{\mathrm{a}}$ Seção desta Corte, por ocasião do julgamento da Revisão Criminal no 2006.03.00.097397-0, Rel. Desembargador Federal Johonsom Di Salvo, DJF3 14.07.10, p.108, mister reconhecer que não ensejam a exasperação da pena-base inquéritos policiais e ações penais em curso em virtude do princípio constitucional da presunção de inocência. Por outro lado, tendo em vista a grande quantidade de cigarros apreendida, a pena-base deve ser fixada um pouco acima do mínimo legal. Assim, mantenho a pena-base em 01 (um) ano e 10 (dez) meses de reclusão.

Também exemplifica a aplicação da Súmula, relativamente à impossibilidade de consideração dos antecedentes não qualificados para tanto, a Apelação Criminal $00034948720104036114^{206}$, de relatoria do Desembargador Federal Nelton dos Santos, da $2^{\mathrm{a}}$ Turma, julgada em 06/09/2011, que tratando do crime de roubo, previsto no artigo 157, parágrafo $2^{\circ}$, incisos I e II, c/c o artigo 29 do Código Penal, reformou a sentença no que se refere à indevida análise dos antecedentes, mas manteve a pena-base acima do mínimo por outras circunstâncias, nos termos abaixo:

\footnotetext{
205 Apelação Criminal 0000786-97.2010.4.03.6006/MS, Rel. Des. Fed. José Lunardelli, 1 ${ }^{\mathrm{a}}$ Turma, TRF3, j. 20/03/2012.

${ }^{206}$ Apelação Criminal 0003494-87.2010.4.03.6114/SP, Rel. Des. Fed. Nelton dos Santos, $2^{\mathrm{a}}$ Turma, TRF3, j. 06/09/2011.
} 


\begin{abstract}
Note-se que o MM. Juiz considerou, como circunstâncias desfavoráveis, alguns feitos criminais não encerrados definitivamente, o que contraria a Súmula 444 do Superior Tribunal de Justiça. Por outro lado, são tantas as circunstâncias desfavoráveis ao réu que a pena-base deveria ter sido fixada em patamar superior, máxime quando do corpo da sentença ainda se colhem outras circunstâncias que também evidenciam a maior gravidade da conduta. Veja-se: "As circunstâncias da ação criminosa especificadas nos depoimentos testemunhais mostram que o acusado e seus comparsas preparam-se ardilosamente para execução do crime. Escolheram o horário mais adequado para acessar o estabelecimento bancário, comunicaram-se por rádio, inclusive com pessoas que estavam fora da agência, conheciam os procedimentos de abertura dos cofres e alarme, evitavam tocar em gavetas, sabiam quem era a gerente, estavam conectados com a freqüência da polícia, agiram em equipe para controlar reféns e não levantar suspeita e voltaram à cena do crime para subtrair fitas de gravação e assegurar a impunidade" (f. 695-verso). Assim, ainda que sejam desconsiderados os feitos criminais não encerrados definitivamente, as circunstâncias apontadas pelo próprio juiz a quo no tópico específico da dosimetria, somadas àquelas colhidas do corpo da sentença, justificam uma penabase de 7 (sete) anos de reclusão, não havendo aí qualquer exagero, já que se trata apenas do ponto médio entre o mínimo e o máximo previstos em lei. A pena de multa, por sua vez, pode e deve ser elevada para 60 (sessenta) dias-multa, quantum que guarda melhor relação de proporcionalidade com a gravidade do delito.
\end{abstract}

Outros casos em que o Tribunal, acatando pleito da Acusação, reformou sentença absolutória, para condenar o réu, e aplicando a Súmula 444, fixar a pena base no mínimo legal. $^{207}$

Por outro lado, também houve julgamento em que se rechaçou recurso do Ministério Público, que objetivava o recebimento de denúncia, rejeitada pelo juízo de primeiro grau, pela aplicação do princípio da insignificância, uma vez que a Acusada não possuía antecedentes, em conformidade com a Súmula 444 do STJ.

Este caso é interessante, pois trata de Recurso em Sentido Estrito, interposto pelo Ministério Público, contra decisão que rejeitou denúncia contra a ré, que lhe imputava o crime previsto no artigo 334, parágrafo primeiro, alínea “c”, por ter sido apreendida com 540 pacotes de cigarros de procedência alienígena, introduzidos clandestinamente a partir do Paraguai, para venda na Cidade de Ribeirão Preto, uma vez que o juízo de primeira instância, baseado no valor de $\mathrm{R} \$ 1.620,00$, atribuído pela denúncia, aos cigarros, aplicou o princípio da insignificância, tanto pelo valor dos cigarros, como pela suposta carga tributária elidida, posto que inferior a $\mathrm{R} \$ 10.000,00$.

207 Apelação Criminal 0005430-92.2000.4.03.6181/SP, Rel. Des. Fed. Ramza Tartuce, 5a Turma, TRF3, j. 19/03/2012; e Apelação Criminal 0012402-49.1999.4.03.6105/SP, Rel. Juíza Convocada Silvia Rocha, 5ª Turma, TRF3, j. 30/08/2011. 
Tal Recurso objetivava questionar a aplicação do princípio da insignificância ao crime imputado a ré, e também demonstrar que não lhe era possível eventual aplicação, uma vez ostentar antecedentes criminais, o que seria incompatível com o princípio bagatelar.

E o Tribunal, aplicando a Súmula, afastou a incidência dos antecedentes, uma vez que desconforme com a orientação sumular.

Enfim, na singularidade do caso é irrelevante para afastar a incidência do princípio da insignificância a presença de antecedentes referidos na "folha de antecedentes" que se encontra a fls. 77/78, porque se referem a inquéritos e processos em andamento, que são inaproveitáveis para esse fim na dicção da Súmula n ${ }^{\circ} 444 / S T J$. O mesmo ocorre com um processo que tramitou no Juizado Especial Criminal, já que consta a extinção da punibilidade do mesmo. Ante o exposto, nego provimento ao recurso em sentido estrito. ${ }^{208}$

Dos 125 (cento e vinte e cinco) acórdãos, 11 (onze) não se tratavam diretamente da Súmula, ora porque se referiam a casos de tráfico de drogas, nos quais a pena-base fora fixada acima do mínimo legal, por conta da quantidade da droga apreendida, não guardando relação com as condições da Súmula $444^{209}$; ora porque os casos estudados não possuíam as características necessárias à aplicação da Súmula, e as sentenças de primeiro grau tinham fixado pena mínima ${ }^{210}$; ora porque, em função de ter sigilo decretado, não foi possível acessar o conteúdo, e verificar se houve aplicação da Súmula ou não ${ }^{211}$.

Do universo estudado, 7 (sete) não aplicaram a Súmula. Dentre estes, 3 (três) são acórdãos proferidos em revisões criminais, em que o Tribunal entendeu não ser possível a redução da pena, uma vez que inexistente a Súmula na ocasião do julgamento dos casos, não

\footnotetext{
${ }^{208}$ RSE 0008251-39.2005.4.03.6102/SP, Rel. Johonsom di Salvo, $1^{\text {a }}$ Turma, TRF3, j. 22/11/2011.

${ }^{209}$ A título de exemplo as Apelações Criminais 0005746-30.2009.4.03.6104/SP, Rel. Des. Fed. Vesna Kolmar, $1^{\mathrm{a}}$ Turma, TRF3, j. 20/09/2011, 0000430-88.2009.4.03.6119/SP, Rel. Des. Fed. José Lunardelli, $1^{\text {a }}$ Turma, TRF3, 17/05/2011 e 0003159-66.2007.4.03.6181/SP, Rel. Des. Fed. Cotrim Guimarães, 2 ${ }^{\mathrm{a}}$ Turma, TRF3, j. 26/10/2010.

${ }^{210}$ Apelação Criminal 0105371-75.1998.4.03.6119/SP, Rel. Des. Fed. Antonio Cedenho, 5a Turma, j. 9/11/2011 (neste caso, a sentença havia fixado pena mínima, mas o Tribunal aumenta em função das circunstâncias do crime) e Apelação Criminal 0009240-70.2003.4.03.6181/SP, Rel. Des. Fed. Cotrim Guimarães, 2a Turma, j. 10/05/2011 (neste caso, o Ministério Público apelou para majorar a pena, por entender que o crime causou muitos prejuízos ao Estado, mas o Tribunal manteve a pena-base no mínimo).

${ }^{211}$ Apelação Criminal 0082006-69.2005.4.03.0000/SP e Apelação Criminal 29380 (proc. 2004.61.81.000243-2). Em função de tramitarem em segredo de justiça, não foi possível acessar os dados dos julgamentos.
} 
existindo, portanto, erro do magistrado de primeiro grau no momento da sentença, não podendo os efeitos da Súmula retroagirem ${ }^{212}$.

Encontram-se, dentre estes, aqueles em que o Tribunal declara ter conhecimento da Súmula, negando-lhe efeito vinculante, entendendo por deliberadamente não aplicá-la.

O mais emblemático em que o Tribunal optou por não aplicar a Súmula 444 é o da Apelação Criminal 0003562-45.2001.4.03.6181/SP, de relatoria do Desembargador Federal Luiz Stefanini, da $5^{\text {a }}$ Turma, julgada em 11/04/2011.

De fato, neste caso, houve tanto apelação do réu, que fora condenado pelo crime de estelionato majorado contra a previdência, como do Ministério Público, com o objetivo de reformar sentença absolutória de outras duas rés. E o Tribunal negou provimento a ambas as apelações, mantendo para o réu condenado os termos da sentença de primeira instância, por também considerar que os inúmeros feitos criminais ostentados, nas mesmas condições de tempo, lugar e modo de execução, deviam ser considerados para aferição da personalidade delitiva, não havendo violação ao princípio da presunção de inocência.

Passo ao exame da dosimetria da pena objeto do recurso. Entendo por irretocável a sanção imposta. Por primeiro, ressalto não desconhecer a Súmula $n^{\circ} 444$ do STJ. Porém, considerando os inúmeros feitos criminais a que responde o acusado, todos perpetrados nas mesmas condições de tempo, lugar e modo de execução, já com diversas condenações, inclusive, provenientes desta E. $5^{\text {a }}$ Turma e também das demais Turmas da E. $1^{\text {a }}$ Seção deste Tribunal, entendo que tais fatores, evidentemente, devem ser considerados para aferição da personalidade delitiva, não havendo falar-se, em casos como tais, em infringência ao princípio da presunção de inocência. É notório, pois, ao menos no âmbito da E. $1^{\text {a }}$ Seção desta Corte, os inúmeros julgamentos já proferidos por este Tribunal, reconhecendo as fraudes perpetradas pelo apelante, não se podendo fechar os olhos para tais circunstâncias. Assim, em que pese a inexistência de notícia de trânsito em julgado em tais feitos criminais, tenho que, considerando todo o contexto e histórico da conduta delitiva perpetrada pelo réu (foram centenas de casos de obtenção de benefícios previdenciários por meio fraudulento, com inúmeras condenações em primeiro e segundo graus de jurisdição perante a Justiça Federal da $3^{\text {a }}$ Região), entendo que devem ser mantidas as reprimendas impostas em primeiro grau, assim como o regime prisional aplicado, sendo incabível, pelas mesmas razões, a substituição da pena privativa de liberdade por restritivas de direitos. Com efeito, tem o réu inúmeros registros criminais, todos eles voltados à prática de crime da mesma modalidade, com utilização de documentos falsos tendo causado prejuízo de grande monta ao INSS e a toda sociedade composta por segurados e pessoas que necessitam da Previdência Social para sobreviver. Por essa razão, tenho por adequada pena acima

${ }^{212}$ Revisões Criminais 0014445-52.2010.4.03.0000/SP, Rel. Des. Fed. Johonsom di Salvo, $1^{\mathrm{a}}$ Turma, TRF3, j. 15/09/2011, 0041815-26.1998.4.03.0000/SP, Rel. Des. Fed. Cotrim Guimarães, $1^{a}$ Turma, TRF3, j. 21/10/2010 e 0097397-30.2006.4.03.0000/SP, Rel. Des. Fed. Johonsom di Salvo, $1^{\text {a }}$ Turma, j. 06/05/2010. 
do mínimo legal, em 02 (dois) anos de reclusão e 30 dias-multa, como acertadamente deduzido pelo MM. Juiz. ${ }^{213}$

Já, na Apelação Criminal 0007070-23.2002.4.03.6000/MS ${ }^{214}$, o Tribunal não fala diretamente em negar vigência à Súmula, justificando sua não aplicação ao fato de a personalidade e conduta social do acusado terem sido avaliadas com base em elementos idôneos, e não nos maus antecedentes (entendam-se apontamentos que não podem ser tecnicamente considerados maus antecedentes). Entretanto, a Corte não aponta sequer um elemento idôneo que pudesse fundamentar a má avaliação da personalidade e conduta social.

Na Apelação Criminal 0002082-03.1999.4.03.6181/SP ${ }^{215}$, o Tribunal não aplicou a Súmula para redução de pena, porque considerou condenação não transitada em julgado, na época dos fatos, na avaliação da personalidade do réu, como voltada ao crime. Negou, portanto, vigência à Súmula.

\begin{abstract}
Além disso, foi também definitivamente condenado, no ano de 2007, nos autos da ação penal $\mathrm{n}^{\circ}$ 0105498-89.1996.4.03.6181, posteriormente, pois, ao fato ora em apuração, conforme consulta ao sistema processual de primeira instância da Justiça Federal da $3^{a}$ Região, tendo este E. Tribunal negado provimento ao recurso da defesa em agosto de 2007. Assim, ainda que a condenação definitiva supracitada tenha ocorrido após a prática delitiva em questão, e não possa, assim, ser considerada como reincidência ou maus antecedentes, resta claro que o acusado possui personalidade distorcida e voltada à prática de crimes, razão por que entendo correta a aplicação da pena-base em dois anos e seis meses de reclusão.
\end{abstract}

A seguir as respostas aos quesitos que se pretendeu investigar, mediante a pesquisa guiada.

Desembargadores

1) Os desembargadores aplicam a Súmula 444 do STJ?

213 Apelação Criminal 0003562-45.2001.4.03.6181/SP, Rel. Des. Fed. Luiz Stefanini, 5 ${ }^{\mathrm{a}}$ Turma, TRF3, j. 11/04/2011.

214 Apelação Criminal 0007070-23.2002.4.03.6000/MS, Rel. Des. Fed. José Lunardelli, 1 ${ }^{\mathrm{a}}$ Turma, TRF3, j. 14/06/2011.

215 Apelação Criminal 0002082-03.1999.4.03.6181/SP, Rel. Des. Fed. Luiz Stefanini, 5 ${ }^{\mathrm{a}}$ Turma, TRF3, j. 14/03/2011. 
Sim. Dos 125 (cento e vinte e cinco) casos analisados, em 90 (noventa), houve sua aplicação, valendo enfatizar, como já dito anteriormente, que dos 125 (cento e vinte e cinco), 28 (vinte e oito) não se tratam da súmula diretamente, seja porque são de matéria cível e tributária, seja porque julgados antes de sua edição, seja porque envolvem casos de aumento da pena mínima por outras circunstâncias dos casos. Destaca-se, ainda, que houve 22 (vinte e dois) feitos, em que a Súmula foi aplicada de ofício, ou seja, sem pleito expresso da defesa.

2) Qual a extensão que lhe é conferida? A) antecedentes; B) conduta social ou C) personalidade.

Ficou claro na pesquisa que a extensão é genérica. Englobando tanto antecedentes, quanto conduta social e personalidade. Assim como no Superior Tribunal de Justiça, a Súmula é entendida como a impossibilidade de se avaliarem os apontamentos criminais (aqueles que não são tecnicamente considerados como maus antecedentes) na vida pregressa do réu, seja a título de antecedentes, seja para desvalorizar a conduta social, ou personalidade.

Dos casos analisados, verificou-se que a reforma das decisões deu-se, na grande maioria, porque os apontamentos na ficha criminal dos réus foram equivocadamente considerados como maus antecedentes. Em termos de números, estes somaram 56 (cinqüenta e seis) casos.

No entanto, houve muitos em que o Tribunal também manifestou entendimento de que tais apontamentos não podiam servir para aumentar a pena mínima, seja por indevidamente serem considerados como antecedentes, seja por conduta social. Estes somaram 26 (vinte e seis) julgados. Já os casos em que indicavam tais apontamentos para avaliar a personalidade totalizaram 32 (trinta e dois).

Nestes, percebe-se que os juízes de primeiro grau utilizaram dos apontamentos criminais para atribuir aos acusados conduta social desvirtuada dos valores morais, personalidade delitiva, voltada para o crime, dentre outros adjetivos, que como bem pontuado nos acórdãos, que os reviu, não tinham fundamento em elementos idôneos nos autos. 
A análise demonstrou a real necessidade de a Súmula ter sido compreendida como a impossibilidade de avaliar os apontamentos criminais em sede de conduta social e personalidade também, pois do contrário, aquilo que não podia ser tecnicamente atribuído aos antecedentes, seria utilizado, indevidamente, para valorar de forma negativa personalidade e conduta social dos réus.

4) Não aplicam a Súmula, sob qual fundamento?

Em 7 (sete) julgados, a Súmula não foi aplicada. Como já mencionado acima, os que tratavam de revisão criminal, o Tribunal entendeu que não tinha efeito retroativo. Em um caso, o Tribunal manifestou entendimento de que não é vinculante e, portanto, não obrigatório sua observância. E, em outro, que a desvalorização da conduta social e personalidade do acusado baseavam-se em elementos idôneos nos autos, não tendo sido levados em conta os apontamentos criminais. O que, de forma, tergiversada, também demonstra a negação da Súmula, na medida em que não se apontam quais elementos idôneos são esses.

A pesquisa em sede do Tribunal Regional Federal da Terceira Região oportunizou acesso, na maioria dos casos, às sentenças de primeira instância, o que possibilitou a verificação dos questionamentos dirigidos aos juízes de primeiro grau. Abaixo, seguem as respostas aos questionamentos inicialmente feitos.

Juízes de Primeiro Grau

1) Quantos julgamentos de primeiro grau ocorreram antes da publicação da Súmula 444 do STJ?

Dos casos analisados, 86 (oitenta e seis) foram julgados anteriormente, sendo interessante mencionar que em 2 (dois) deles, houve o julgamento conforme a orientação da 
Súmula, mesmo antes de sua existência ${ }^{216}$. Há, além desses, 3 (três) sob segredo de Justiça, portanto, sem acesso.

2) Nos julgamentos havidos anteriormente à Súmula, o fundamento do aumento da pena base foi antecedentes, considerando-se, equivocadamente, inquéritos policiais, ações em andamento, sentenças condenatórias sem trânsito em julgado e até atos infracionais? 2.1) Foi conduta social? 2.2) Personalidade do agente?

Os julgamentos são os mais variados possíveis, e na esteira do já apontado em sede de Tribunal, seguem a mesma proporção. A maioria é de antecedentes, considerando-se inquéritos policiais e ações penais em andamento, indevidamente. Tais apontamentos foram muitas vezes utilizados para avaliar como reprovável a conduta social dos acusados, e julgar a personalidade desvirtuada ou voltada para a prática delituosa.

3) Após a edição da Súmula, os magistrados de primeiro grau a aplicaram?

Não, pois dos casos analisados, 6 (seis) se deram após a publicação da Súmula e, em apenas 1 (um), o juiz monocrático a aplicou. Nos demais, houve completa desconsideração à letra da Súmula. Emblemático o da Apelação 0003494-87.2010.4.03.6114-SP ${ }^{217}$, em que o juiz entende que os "antecedentes" seriam gravíssimos, desfavorecendo o acusado na análise de sua personalidade. O mesmo se diz da Apelação 0000379-60.2011.4.03.6102-SP ${ }^{218}$, em que foram consideradas, pelo juízo monocrático, as passagens policiais do acusado como conduta social desfavorável.

\footnotetext{
${ }^{216}$ RSE 0008251-39.2005.4.03.6102-SP, Rel. Des. Fed. Johonsom di Salvo, $1^{\text {a }}$ Turma, TRF3, j. 22/11/2011 e ACR 0003379.18.2000.4.03.6114-SP, Rel. Des. Fed. Nelton dos Santos, $2^{\text {a }}$ Turma, TRF3, 30/08/2011. Em ambos os casos, o Ministério Público recorreu. No primeiro caso, a fim de que fosse recebida denúncia, por conta dos antecedentes do acusado; e no segundo para que houvesse aumento da pena mínima, considerando os apontamentos criminais como má conduta social.

${ }^{217}$ Apelação Criminal 0003494-87.2010.4.03.6114, Rel. Des. Fed. Nelton dos Santos, 2 $2^{\mathrm{a}}$ Turma, TRF3, j. 06/09/2011.

${ }^{218}$ Apelação Criminal 0000379-60.2011.4.03.6102, Rel. Des. Fed. Cotrim Guimarães, $2^{\mathrm{a}}$ Turma, TRF3, j. 06/09/2011.
} 
A amostra utilizada para estudo demonstrou que o impacto da Súmula é maior junto à segunda instância. Tanto que em esmagadora maioria, houve a aplicação nos julgamentos. Já quanto aos juízes monocráticos, mesmo após a edição da Súmula, viu-se a resistência em acatá-la.

Ainda que não conste expressamente na pesquisa, interessante apontar que, em praticamente todos os casos levados à revisão do Tribunal, os pareceres do representante do Ministério Público em segunda instância eram pelo não provimento dos recursos da defesa, e pelo provimento dos da acusação, demonstrando, de certa forma, desrespeito com a letra da Súmula.

\subsubsection{Decisões do Tribunal de Justiça de São Paulo}

No Tribunal de Justiça de São Paulo, a pesquisa foi efetuada, por meio do sitio eletrônico www.tjsp.jus.br, no ícone Jurisprudência, no Campo Pesquisa Livre, com as seguintes palavras-chave "Aplicacao da Sumula 444 do STJ". A data da realização da pesquisa foi $01 / 07 / 2013$.

Para a pesquisa no Tribunal Estadual, além do Campo Pesquisa Livre, é necessário especificar um período de 1 (um) ano, para o filtro dos julgados. Inicialmente, até para acompanhar a data final da pesquisa efetuada no Tribunal Regional Federal da $3^{\mathrm{a}}$ Região, fixou-se o interregno de 27/03/2011 a 26/03/2012.

O filtro dos julgados trouxe o elevado número de 1276 (um mil, duzentos e setenta e seis) acórdãos.

Como a pesquisa não tem caráter quantitativo, não objetivando traçar estatística dos julgados, optou-se por restringir o período, de forma que novo filtro fora efetuado. Desta feita, entre o interregno de 26/01/2012 a 26/03/2012, o que trouxe 225 (duzentos e vinte e cinco) acórdãos para análise. Dentre estes, estavam julgados de Câmaras Privadas e Públicas, que foram afastados, por não terem função para o estudo em questão.

Separamos 59 (cinqüenta e nove) julgados, que tratavam da Súmula, para fins de estudo. 
O estudo no âmbito do Tribunal Estadual foi menos detalhado se comparado ao Federal, porque não franqueou acesso às sentenças de primeiro grau, e em apenas alguns casos, foi possível verificar as datas dos julgamentos em primeira instância, porque citados no corpo dos acórdãos. Portanto, a segunda parte da enquete, direcionada aos juízes, não pôde ser realizada.

De toda forma, apenas a título ilustrativo, e para referendar a resistência dos magistrados singulares em aplicar a Súmula, citam-se cinco casos em que as sentenças, ocorridas após a sua publicação, não a observaram. São as apelações criminais 003890490.2010.8.26.0050-SP ${ }^{219}, \quad$ 0005870-62.2009.8.26.0082-Boituva ${ }^{220}, \quad$ 000680328.2010.8.26.0073-Avaré ${ }^{221}, \quad 0005160.13 .2010 .8 .26 .0048-$ Atibaia $^{222}$, e $\quad 0003046-$ 20.2010.8.26.0366-Mongaguá ${ }^{223}$.

A falta de acesso ao inteiro teor das sentenças não permitiu aferir, com precisão, a justificativa para o não acatamento da Súmula.

No entanto, no acórdão relativo à apelação da Comarca de Mongaguá ${ }^{224}$, ficou claro e expresso que a juíza de primeiro grau julgou contrariamente à Súmula, por entender que não havia efeito vinculante.

Com efeito, neste caso, a magistrada de primeira instância condenou o réu, pela prática do crime previsto no artigo $157, \S 2^{\circ}$, incisos I e II, do Código Penal, e procedeu ao aumento da pena-base em 1/6 acima do mínimo legal, considerando, indevidamente, inquéritos policiais em andamento, como antecedentes, por não conferir obrigatoriedade à Súmula 444 do STJ.

Foi fixada a pena-base em 1/6 acima do mínimo legal, sob o fundamento de que não são favoráveis ao acusado as circunstâncias judiciais, afastando-se expressamente a

\footnotetext{
${ }^{219}$ Apelação Criminal 0000379-60.2011.4.03.6102, Rel. Des. Poças Leitão, $15^{\text {a }}$ Câmara de Direito Criminal, TJSP, j. 15/03/2012.

${ }^{220}$ Apelação Criminal 0005870-62.2009.8.26.0082-Boituva, Rel. Des. Souza Nucci, 16a Câmara de Direito Criminal, TJ-SP, j. 20/03/2012.

${ }^{221}$ Apelação Criminal 0006803-28.2010.8.26.0073-Avaré, Rel. Des. Paulo Rossi, $2^{\text {a }}$ Câmara de Direito Criminal, TJ-SP, j. 12/03/2012.

${ }^{222}$ Apelação Criminal 0005160.13.2010.8.26.0048-Atibaia, Rel. Des. Paulo Rossi, 2a Câmara de Direito Criminal, TJ-SP, j. 12/03/2012.

${ }^{223}$ Apelação Criminal 0003046-20.2010.8.26.0366-Mongaguá, Rel. Des. Silmar Fernandes, 6a Câmara de Direito Criminal, TJ-SP, j. 02/02/2012.

${ }^{224}$ Apelação Criminal 0003046-20.2010.8.26.0366-Mongaguá, Rel. Des. Silmar Fernandes, $6{ }^{a}$ Câmara de Direito Criminal, TJ-SP, j. 02/02/2012. (destaques nossos)
} 
aplicação da Súmula 444 do Superior Tribunal de Justiça, por considerar o seu caráter não vinculante." Mas não é assim. Em que pese o entendimento do MM. Juiz a quo, a majoração da pena basilar em razão dos maus antecedentes não se justifica. Compulsando-se os autos, verifica-se a inexistência de qualquer informação acerca de condenações anteriores transitadas em julgado ostentadas pelo réu, não obstante o expressivo número de inquéritos tramitando em seu desfavor. Aliás, a jurisprudência é pacífica em entender que apenas condenações irrecorríveis incapazes de gerar reincidência podem ser consideradas como maus antecedentes, afastando-se, assim, a possibilidade de serem utilizados inquéritos policiais e processos em curso. Nesse sentido, o Colendo Superior Tribunal de Justiça editou a Súmula $\mathrm{n}^{\circ} .444$, segundo a qual "É vedada a utilização de inquéritos policiais $e$ ações penais em curso para agravar a pena-base".

No Tribunal, pode-se afirmar que os desembargadores cumpriram a Súmula, aplicando-a, inclusive, de ofício, naqueles casos em que não havia pleito específico da defesa.

Diferentemente do ocorrido no Tribunal Federal, no Estadual, houve aplicação da Súmula, em sede da Revisão Criminal 0232754-65.2010.8.26.0000-Jales ${ }^{225}$, para afastar os antecedentes equivocadamente avaliados, para aumento da pena mínima.

A Revisão Criminal foi ajuizada, com objetivo de desconstituir acórdão, que por votação unânime, negou provimento à apelação do réu contra sentença que o condenou à pena de 13 (treze) anos, 8 (oito) meses e 20 (vinte) dias de reclusão, em regime fechado, e 34 (trinta e quatro) dias-multa, no piso, por infringir os artigos 157, § 2o, I e II e 157, § 2o, I, c.c. o artigo 71, todos do Código Penal e artigo 157, § 2o, I e II, do mesmo diploma.

Um dos fundamentos da Revisão Criminal era justamente a redução da pena imposta, uma vez que baseada em juízo equivocado de maus antecedentes, por se levar em conta processos que estavam em curso, mas sem trânsito em julgado.

A Revisão foi parcialmente provida, deferindo-se o pedido de redução de pena, sob a justificativa que em situações de evidente injustiça e erro técnico, é possível a correção do julgado, nos seguintes termos:

O pedido de redução das penas impostas pelos crimes de roubos biqualifícados comporta parcial deferimento, para afastar o aumento pelos maus antecedentes, como adiante se verá. Em que pese não ser admissível o reexame da pena, em sede de revisão criminal, anote-se, por outro lado, que há sólido entendimento de que, em situações de evidente injustiça e erro técnico na dosimetria, é possível a correção do

${ }^{225}$ Revisão Criminal 0232754-65.2010.8.26.0000-Jales, Rel. Des. Antonio Manssur, 6º Grupo de Câmara de Direito Criminal, TJ-SP, j. 29/02/2012. 
julgado. ... No caso, há de ficar consignado que não se discute a autoria e a materialidade delitivas, pelo que se afigura desnecessária qualquer discussão a respeito. a) Do aumento de pena pelos maus antecedentes: Razão assiste ao peticionário. Com efeito, verifíca-se dos autos que não há trânsito em julgado referente às condenações anteriores à prática dos crimes retratados nesses autos, de forma que não poderia ter sido a pena-base exacerbada sob o fundamento de que o peticionário ostenta maus antecedentes. Nesse sentido é o disposto no enunciado da Súmula 444, do C. STJ: "£ vedada a utilização de inquéritos policiais e ações penais em curso para agravar a pena-base." Do exposto, defere-se parcialmente o pedido revisional, para reduzir as penas do peticionário para 12 (dozes) anos, 4 (quatro) meses e 14 (quatorze) dias de reclusão, em regime fechado, e 4 (quatro) dias-multa, no mínimo legal, por infringência dos artigos 157 , § 2o, I e II e 157 , § 2o, I, c.c. o artigo 71, e artigo 157, § 2o, I e II, todos do Código Penal.

Do estudo efetuado junto ao Tribunal de Justiça de São Paulo, não se verificou casos em que a Súmula 444 deixou de ser aplicada.

Desembargadores.

1) Os desembargadores aplicam a Súmula 444 do STJ?

Sim. Em todos os casos analisados, a Súmula foi aplicada. Inclusive, de ofício, ou seja, sem pleito expresso da defesa.

2) Qual a extensão que lhe é conferida? A) antecedentes; B) conduta social ou C) personalidade.

Dos 59 (cinqüenta e nove) casos analisados, 49 (quarenta e nove) trataram de antecedentes, 9 (nove) de personalidade e apenas 1 (um) de conduta social.

3) Não aplicam a Súmula, sob qual fundamento? 
Não houve casos.

Tendo finalizado a análise dos julgados quanto à aplicação da Súmula 444 do STJ, passamos a estudar a jurisprudência do Tribunal Regional Federal da $3^{\mathrm{a}}$. Região, com objetivo de verificar o que referida Corte toma por conduta social e/ou personalidade, para fins de fixar a pena-base, acima do mínimo legal. Diferentemente do que ocorrera até o presente momento, no tópico seguinte, tomar-se-á a liberdade de detalhar um pouco mais os casos, com o intuito de bem delinear o conceito emprestado às mencionadas circunstâncias judiciais.

\subsection{Análise de julgados com o fim de verificar o que se considera como personalidade e conduta social para fins de aplicação da pena-base acima do mínimo legal}

\subsubsection{Decisões do Tribunal Regional Federal da $3^{\text {a }}$ Região}

A pesquisa foi realizada, por meio do sitio eletrônico www.trf3.jus.br, no ícone Jurisprudência, no Campo Pesquisa Livre, com as seguintes palavras-chave "Fixação da pena e conduta social e personalidade". A data da realização da pesquisa foi 08/07/2013.

O filtro trouxe 446 (quatrocentos e quarenta e seis) julgados, sendo o mais recente a Apelação Criminal no 0000430-25.2008.4.03.6119/SP, julgada em 25/06/2013, pela $1^{\text {a }}$ Turma, sob a relatoria do Juiz Federal Convocado Márcio Mesquita.

Conforme já ponderado acima, igualmente nessa parte da pesquisa não se objetivou obter dados quantitativos, não obstante falar-se em números. A verificação dos julgados teve como meta analisar o que os julgadores, tanto de primeiro quanto de segundo graus de jurisdição, compreendem como conduta social e personalidade, para fixação da pena-base.

Importante mencionar que, independentemente da análise restringir-se à verificação das circunstâncias conduta social e personalidade, ou seja, à averiguação do que foi levado em conta para se aumentar a pena-base, a título destas circunstâncias; o estudo da jurisprudência, no âmbito do Tribunal Regional Federal da $3^{\text {a }}$ Região, revelou a inexistência de uma ordem, organização ou método, no processo de individualização das penas, como um todo. Revelou, 
ainda, que na fixação da pena, apesar de o artigo 59 do Código Penal estabelecer necessária observância aos critérios de prevenção e retribuição, como finalidades da pena, tal objetivo não é focado pelos julgadores pátrios.

Com efeito, pelo estudo dos julgados, ficou claro não haver por parte dos julgadores um norte certo a ser seguido, na atribuição da pena-base. Vê-se, principalmente, nos crimes de tráfico internacional de drogas, que totalizaram 270 (duzentos e setenta) dos casos analisados, uma enorme variedade de penas estipuladas, sem a observância de qualquer critério lógico.

Há exemplos em que a quantidade da droga apreendida era pequena, e não havia outra circunstância a demandar o aumento da pena-base, tendo este acontecido sem qualquer justificativa. Outros em situações similares, em que se verificou apenamento de forma bem diferenciada, em termos de quantidade.

Tudo a evidenciar o quanto o indivíduo ainda está sujeito ao arbítrio dos julgadores, no momento de receber a pena (principal momento processual para o réu, importa dizer), uma vez que a análise dos julgados demonstrou a falta de critério objetivo a ser seguido.

Como dito acima, até mesmo nos casos onde o critério é objetivo, qual seja, quantidade e natureza da droga apreendida, houve acórdãos, com decisões completamente díspares, para quantidades semelhantes e natureza do entorpecente, e sem qualquer outra especificidade, que justificaria a diferença das penas aplicadas.

Em função desta parte da pesquisa buscar o detalhamento daquilo que é relevante aos magistrados, quando da fixação da pena-base, no que se refere ao trato da conduta social e personalidade, vamos, na medida do possível, colacionar os acórdãos, que a nosso ver, demonstram as incoerências entre os julgados, a falta de critério a ser seguido, e muitas vezes, o total descaso na fixação da pena, vez que lacunosas as justificativas apresentadas, dificultando o controle das decisões.

A análise da jurisprudência pátria foi muito importante à demonstração do quão afastados de limites estão os julgadores, no momento da fixação da pena-base, revelando, por um lado, o perigo para os jurisdicionados e, por outro, a orfandade de nossos juízes de sólidas diretrizes no momento da aplicação da pena. 
Feitas estas considerações prévias, abaixo seguem alguns apontamentos obtidos a partir da análise dos 446 (quatrocentos e quarenta e seis) acórdãos encontrados.

Com efeito, dos 446 (quatrocentos e quarenta e seis) acórdãos analisados, 270 (duzentos e setenta) se referem ao tráfico internacional de drogas. Acredita-se que o elevado número dos casos filtrados envolvendo o assunto diz respeito ao disposto no artigo 42, da Lei 11.343/06, pois expressamente prevê que “o juiz, na fixação das penas, considerará, com preponderância sobre o previsto no art. 59 do Código Penal, a natureza e a quantidade da substância ou do produto, a personalidade e a conduta social do agente”.

Não obstante nesses casos o aumento da pena-base tenha se dado muito mais em função da natureza e quantidade de droga apreendida, que da averiguação da personalidade e conduta social dos agentes, propriamente ditas, a análise dos julgados demonstrou, como já ponderado acima, o quão falho é o sistema de fixação da pena, que não consegue observar um padrão sequer no que tange a critérios palpáveis, como a quantidade da droga.

Seguem dois exemplos de fixação da pena-base com fulcro exclusivo na quantidade e natureza do entorpecente, em que as justificativas dos desembargadores são completamente díspares.

Na Apelação 0008337-85.2007.4.03.6119/SP, de relatoria da Desembargadora Federal Vesna Kolmar, da $1^{\text {a }}$ Turma, julgada em 09/12/2008, o Réu, em função de ter sido apreendido com $1.385 \mathrm{~kg}$ de cocaína, teve a pena-base fixada no mínimo legal, sob a justificativa de que a quantidade não destoava do ordinariamente apreciado na Turma, e não era uma droga extraordinária no âmbito da traficância, nos seguintes termos:

Na primeira fase do procedimento dosimétrico, pretende a defesa a redução da penabase ao mínimo legal. Pois bem. Nos termos do artigo 42 da Lei n $11.343 / 06$, devese considerar com preponderância a natureza e a quantidade da substância entorpecente, bem como a personalidade e conduta social do agente. Com relação às duas últimas circunstâncias acima elencadas, nada se sabe, pois o réu é estrangeiro. Quanto à natureza da substância, trata-se, na verdade, de cocaína, que representa a "droga do momento", cujo consumo superou o da maconha, e assim sendo, não é uma droga extraordinária no âmbito da traficância, não tendo aptidão para impressionar no caso concreto. Por último, a quantidade - pouco mais de um quilo não destoa do ordinário que se tem apreciado a cada sessão de julgamento da Egrégia Primeira Turma, portanto, também não pode ser tida como de especial repercussão para fins de exacerbação da reprimenda. Pelas razões discorridas, a pena-base deve ser fixada no patamar mínimo de 05 (cinco) anos de reclusão. 
Já na Apelação Criminal 0008025-75.2008.4.03.6119/SP, de relatoria da Desembargadora Federal Ramza Tartuce, da $5^{\text {a }}$ Turma, julgada em 26/04/2010, o Réu, apesar de ter sido apreendido com 550 gramas de cocaína, teve a pena-base fixada em 1/6 (um sexto) acima do mínimo legal, pois os julgadores entenderam que tal montante de cocaína é quantidade considerável a justificar maior reprimenda, nos seguintes termos:

No que se refere à fixação da pena-base, como se observa do auto de apreensão (fls. fls. 18/19, 44/45) e do laudo de exame em substância (fls. 131/133 e 138/139), foi apreendida, em poder do acusado, certa quantidade de substância entorpecente altamente deletéria, com enorme poder de criar vício e dependência (cocaína) e em montante considerável, como já dito (550 gramas), o que denota, sem dúvida, uma maior culpabilidade e lesão mais intensa ao bem jurídico tutelado (saúde pública), justificando o recrudescimento da sanção penal, atendendo, inclusive, o comando normativo inserto no art. 42 da Lei $\mathrm{n}^{\mathrm{o}}$ 11.343/06: "O juiz, na fixação das penas, considerará, com preponderância sobre o previsto no art. 59 do Código Penal, a natureza e a quantidade da substância do produto, a personalidade e a conduta social do agente". E não há que se falar que a quantidade apreendida com o apelante não é considerável, uma vez que, após o seu "preparo" pelos traficantes, sua massa se multiplicaria e seria capaz de alcançar um enorme número de usuários, trazendo gravíssimas consequiências à saúde pública.

Em ambos os casos, nenhuma circunstância judicial foi tomada como desfavorável à determinação da pena-base, que foi fixada com fulcro, exclusivamente, na quantidade do entorpecente, uma vez que a natureza era a mesma nos dois acórdãos paradigmas. De modo que fica o questionamento sobre o que é levado em consideração para deliberação da pena, se até nas hipóteses de critério objetivo, vê-se a falta de baliza para a determinação da quantidade que seria suficiente ao aumento da pena-base além do mínimo.

Os dois exemplos acima são apenas alguns dos tantos existentes dentro do espectro estudado, relativos às injustificadas diferenciações no apenamento dos acusados, que foram apreendidos com quantidades semelhantes de drogas. Eles foram os escolhidos porque, ao ver da pesquisadora, melhor plasmam a esquizofrenia do sistema de fixação de penas.

Como não se pretende traçar um gráfico, com os números levantados, de forma rígida, mas tão somente uma fotografia da situação dos julgados e suas penas-bases, ressalta-se que seguindo a mesma sistemática mencionada acima, somente serão colacionados os julgados que melhor ilustram as falhas na aplicação das penas. 
Dessa forma, seguem-se outras disparidades, a fim de verificar a situação de incerteza e falta de segurança, que se encontra a Justiça Brasileira.

Ainda com relação ao aumento da pena-base, com fundamento exclusivo na quantidade do entorpecente, cabe advertir que a maioria dos acórdãos estudados tratou das "mulas"226, sendo possível afirmar que os julgadores não levam em consideração que, em grande parte dos casos, estas pessoas não têm informação da quantidade e natureza dos produtos transportados.

Não se pretende, neste trabalho, travar qualquer discussão quanto à justiça ou não do aumento da pena, com fulcro apenas na quantidade da droga, mas tão somente ponderar que, consoante consigna o defensor público federal Pablo Luiz Amaral, as ditas "mulas" não possuem qualquer ingerência sobre o "quantum" e a natureza do entorpecente transportada, de forma que vincular o aumento da pena-base à sua quantidade, como fator preponderante sobre qualquer outro, desconsiderando este dado da falta de conhecimento dos "transportadores", pode consistir sim em injustiça. ${ }^{227}$

\footnotetext{
${ }^{226}$ Pessoas utilizadas pelos traficantes para transportar a droga.
}

227 “A saída para uma justa fixação da pena, como já dito acima, encontra-se na necessidade imediata que o Estado Julgador reconheça a situação de vulnerabilidade daquelas pessoas que foram utilizadas pelos grandes cartéis para transportar suas drogas para outras localidades. Dentro desta ótica, o magistrado não poderia nem deveria invocar a aplicação do art. 42 da Lei 11343/2006 para elevar à pena-base em razão da "natureza e a quantidade da substância ou do produto". Isso porque, e esta parece ser a regra geral, o transportador da droga não detém conhecimento do montante e nem da natureza do produto que lhe é repassado. A droga, geralmente, é acondicionada em fundos falsos ou posta no interior de objetos inseridos nas bagagens que são entregues por integrantes das organizações criminosas aos transportadores. Estes, por sua vez, as recebem lacradas ou, então, desconhecem o teor e a quantidade do produto que foi armazenado em seu interior. Assim, eventual elevação da pena em razão do montante de drogas encontrado com o transportador não se justificaria. O magistrado, na hipótese de elevar a pena em razão desta circunstância, provavelmente presumirá que o transportador detinha ciência do quantitativo de entorpecente que trazia consigo. Tal presunção, é bom esclarecer, geralmente não é acompanhada de nenhum suporte probatório. Primeiro, porque o transportador, em juízo, geralmente declara desconhecer a quantidade e a natureza da substância transportada; segundo, não há a determinação de realização de perícia técnica nas substâncias entorpecentes apreendidas, capaz, por si só, de apontar se o transportador havia ou não as manipulado, o que poderia gerar uma certeza quase absoluta sobre o seu conhecimento a respeito do quantitativo e natureza do objeto transportado. Injustificável, pois, a elevação da pena com base em presunções ou suposições". (Pablo Luiz Amaral, Da mitigação do art. 42 da lei 11343/2006 em face da realidade sombria enfrentada pelas "mulas" do tráfico. Artigo publicado em 15/02/2013, no Conteúdo Jurídico. Disponível em: <http://www.conteudojuridico.com.br/artigo,da-mitigacao-do-art-42-da-lei-113432006-em-face-da-realidadesombria-enfrentada-pelas-mulas-do-trafico,42097.html>. Acesso em 09 ago. 2013. 
Dos acórdãos estudados, o que se percebe é que não há qualquer interesse na perquirição do envolvimento real do réu, na organização criminosa. Parte-se do pressuposto que existe, apenas porque se não fosse pelo trabalho das "mulas", o tráfico restaria prejudicado, o que evitaria a distribuição da droga. Colocam-se as "mulas" na cadeia de distribuição da droga, atribuindo-lhes papel nada coadjuvante ${ }^{228}$.

Não há como deixar de concluir que as chamadas "mulas" contribuem para o êxito da organização dedicada ao tráfico de entorpecentes, sobretudo por se tratar de tráfico internacional entre dois continentes, que, por óbvio, exige maior elaboração. ${ }^{229}$

XI - Embora não tenha sido comprovado que o réu integra organização criminosa, a sua situação beira aquela em que a causa de diminuição é vedada, pois a chamada "mula", embora não se compare com os chefes do tráfico internacional, exerce papel de grande importância para o esquema criminoso, atuando no transporte da droga. ${ }^{230}$

Descuidam os julgadores, quando assim procedem, que muitas vezes, as hoje "mulas" são as prostitutas de outrora, que não servindo mais para este ofício, ficam à mercê de seus aliciadores, para o trabalho que determinarem.

Parece que nossos julgadores desconhecem a triste realidade do tráfico de seres humanos, que transformam prostitutas e escravos em "mulas", que temendo por suas vidas e a de seus familiares, executam qualquer trabalho, inclusive a ingestão da droga para o transporte ${ }^{231}$.

Com relação às "mulas", é interessante notar que há julgados em que a ingestão da droga foi o fator determinante pelos julgadores, para se aferir a personalidade negativa.

\footnotetext{
228 “Ainda que o condenado por tráfico transnacional de drogas seja primário, de bons antecedentes e que não existam provas de que se dedique a atividades criminosas, se figurou, ainda que de forma eventual, na ponta de uma organização criminosa, a ela prestando serviços e colaborando para a distribuição mundial do entorpecente cocaína, ao exercer a função de "mula" de grande quantidade de drogas para o exterior mediante remuneração, integrou a organização criminosa, não preenchendo, pois, de forma cumulativa os requisitos exigidos para a aplicação da causa de redução de pena prevista no $\S 4^{\circ}$ do artigo 33, da Lei 11.343/06. Exclusão do benefício.” (ACR 0010410-28.2009.4.03.6000/MS, Rel. Juiz Convocado Rubens Calixto, 5a Turma, TRF3, j. 17/12/2012).

${ }^{229}$ ACR 0008830-62.2007.4.03.6119/SP, Rel. Des. Fed. Cotrim Guimarães, $2^{\mathrm{a}}$ Turma, TRF3, j. 19/05/2009.

${ }^{230}$ ACR 0012884-03.2009.4.03.6119/SP, Rel. Des. Fed. Cecilia Mello, $2^{\mathrm{a}}$ Turma, TRF3, j. 29/11/2011.

${ }^{231}$ Palestra "O Tráfico de Pessoas", proferida pelo Dr. Edmundo Oliveira, no $1^{\circ}$ Fórum Mundial Sobre Crime, a Segurança e as Metas da ONU para o Novo Milênio, na data de 06/08/2013, em São Paulo.
} 
Curioso que na questão da ingestão da droga, os julgadores não só desconsideram que, na maior parte das vezes, nos casos das "mulas", tal fato não é uma opção, mas uma obrigação, executada por ameaça, como pior, não conferem importância ao fato de na legislação pátria, não haver punição para a autolesão, não sendo razoável, portanto, aumentar a pena-base do sujeito, sob a justificativa que ao ingerir o entorpecente, assumiu o risco de morrer.

Se não há sequer a possibilidade de incriminar e punir o agente que se autolesiona ou até mesmo tenta o próprio suicídio, como sustentar o aumento de pena da pessoa que ingeriu a droga, sob o pretexto de ter assumido o risco de morte? Ou de melhor suportar o sofrimento? Em que tal fato resvalesce para desvalorizar a personalidade do agente?

O sistema deve ter coerência. O que, definitivamente, não se vislumbra nas decisões em que se tomou a ingestão da droga como mote para o aumento da pena.

Vê-se exemplo do quanto mencionado na Apelação Criminal 000883062.2007.4.03.6119/SP, de relatoria do Desembargador Federal Cotrim Guimarães, da $2^{\mathrm{a}}$ Turma, julgada no dia 19/05/2009, nos seguintes termos:

Sobre a dosimetria da pena, a ingestão de cápsulas de cocaína traduzem uma culpabilidade merecedora de maior reprovabilidade, pois, além de dificultar a ação policial, pressupõe um preparo físico e psicológico do réu ainda maior no cometimento da conduta delituosa e portanto maior periculosidade do agente. A natureza do entorpecente também colabora para a majoração da pena, tendo em vista a amplitude de seu poder de destruição frente a outras drogas. O artigo 42, da Lei 11.343/2006 dispõe, expressamente, que o Juiz, na fixação das penas, considerará, com preponderância sobre o previsto no artigo 59, do Código Penal, a natureza e a quantidade da substância ou do produto, a personalidade e a conduta social do agente. 4. Tratando-se de ingestão de cápsulas de cocaína, não há que se falar em pequena quantidade, levando-se em conta o sofrimento, o risco de morte e o preparo orgânico exigido para que uma pessoa possa engolir 70 (setenta) cápsulas de aproximadamente $11 \mathrm{gr}$ (onze gramas) cada. 5. Dessa maneira, a pena base deve ser estabelecida em 06 (seis) anos e 600 (seiscentos) dias-multa, ou seja, elevada em 1/5 (um quinto), frente às demais circunstâncias não desfavoráveis ao réu, como expressamente constou da r.sentença. ... 7. Na terceira fase, o índice estipulado pela i.Magistrada (metade), no tocante à causa de diminuição da pena referente ao artigo $33, \S 4^{\circ}$, da Lei $11.343 / 2006$, merece reforma. 8. Não há como deixar de concluir que as chamadas "mulas" contribuem para o êxito da organização dedicada ao tráfico de entorpecentes, sobretudo por se tratar de tráfico internacional entre dois continentes, que, por óbvio, exige maior elaboração. Entretanto, o artigo $33, \S 4^{\circ}$, da Lei 11.343/2006 é expresso em elencar os requisitos necessários para sua configuração, quais sejam: agente primário, de bons antecedentes, que não se dedique às atividades criminosas nem integre organização criminosa. Dessa maneira, considerando que o réu é primário e não possui maus antecedentes, inexistindo provas concretas de que, 
efetivamente, se dedicava às atividades criminosas ou integrava organização criminosa, penso não ser possível afastar por completo a mencionada causa de causa de diminuição de pena. Por outro lado, o réu não demonstrou, por qualquer meio, ser merecedor da minorante em seu patamar máximo, tampouco no patamar estabelecido na r.sentença. Ao contrário, as circunstâncias com que o delito foi cometido e a periculosidade intrínseca que o meio utilizado traz, uma vez que dispôs do seu próprio corpo para transportar considerável quantidade de cocaína, revela que a contestada causa de diminuição de pena deve ser aplicada em seu grau mínimo, ou seja, em 1/6 (um sexto), restando a pena estipulada em 04 (quatro) anos e 07 (sete) meses de reclusão.

Como visto, o Tribunal manteve a pena-base fixada acima do mínimo legal, sob o argumento de maior periculosidade do agente, pela ingestão da droga.

O que atualmente é insustentável, na medida em que tal expressão encontra-se abolida do ordenamento jurídico, estando reservada apenas aos inimputáveis.

O réu experimentou prejuízo duplo, pois além da pena-base acima do mínimo, foi lhe conferido menor percentual da causa de diminuição, prevista no artigo $33, \S^{\circ}$, da Lei 11.343/2006, e tudo sob a alegação da periculosidade do meio utilizado para o transporte da droga, com a utilização do próprio corpo.

Outro exemplo encontra-se na Apelação Criminal 00039436920064036119, de Relatoria do Desembargador Federal Johonsom di Salvo, da $1^{\text {a }}$ Turma, julgada no dia 24/06/2008, nos seguintes termos:

A dosimetria da pena não comporta reparo. Ao contrário do entendimento da defesa exposado nas razões recursais, depreende-se do teor do artigo 42 da novel Lei $n^{\circ}$ 11.343/06, que a natureza e a quantidade da substância, bem como a personalidade e a conduta social do agente, são circunstâncias a serem consideradas com preponderância em relação às elencadas no artigo 59 do estatuto repressivo, na primeira etapa da fixação da pena. Como correta e suficientemente fundamentado pelo douto Juiz sentenciante (fls. 189): “(...) Por se tratar de tráfico de cocaína, substância entorpecente de elevado potencial lucrativo no exterior e conseqüências deletérias diante do alto poder tóxico para a saúde pública no consumo disseminado, na quantidade de pouco mais de um quilo, e considerando aspecto da personalidade relacionado ao destemor para o crime na ingestão de cápsulas cuja abertura poderia levar à morte, fixo a pena-base em 05 anos e 06 meses de reclusão e 550 dias-multa". Destaco, outrossim, que a apenação do réu nesta primeira fase revelou-se até módica - aumento de apenas 1/10 sobre o mínimo legal previsto no preceito secundário do artigo 33 da Lei $\mathrm{n}^{\circ}$ 11.343/06 - tendo em vista que o ilustre magistrado de primeira instância deixou de sopesar o motivo propulsor da atuação criminosa, qual seja, a obtenção de dinheiro fácil: MALIK receberia a quantia de U\$2.500 (dois mil e quinhentos dólares) pelo transporte da droga (fls. 100/101). Contudo, impossível corrigir-se a pena ante a ausência de recurso ministerial. 
Neste julgado, percebe-se que o Tribunal referendou o entendimento do juiz de $1^{\mathrm{a}}$ Instância, mantendo a pena-base acima do mínimo, ressentindo não ter havido maior acréscimo, pelo motivo propulsor de obtenção de dinheiro fácil.

Este é um exemplo excelente para demonstrar o que baliza nossos julgadores, no momento de fixação da pena-base. Como visto, a personalidade foi tomada de forma negativa, exclusivamente, pela ingestão da droga, pois nada nos autos desabonava a personalidade do réu, que por ser estrangeiro, não foi possível averiguar.

Extrai-se, igualmente, que a busca do lucro fácil teria sido alçada a circunstância passível de aumento da pena-base, caso o Tribunal pudesse falar sobre o motivo.

No entanto, a busca do lucro fácil já se encontra no próprio elemento do injusto, previsto no artigo 33. Com efeito, as figuras típicas que compõem o núcleo do artigo 33, caput, da Lei 11.343 /06 quase sempre pressupõem comércio e o lucro, de forma que não é possível a exasperação da pena pela promessa de recompensa ou pelo preço recebido, já que está implícita no tipo legal.

Este entendimento, aliás, está plasmado na Apelação Criminal 001041028.2009.4.03.6000/MS, de Relatoria do Juiz Convocado Rubens Calixto, da $5^{\text {a }}$ Turma do TRF3, julgada em 17/12/2012, em que não houve aumento da pena do réu, por entender que o desejo do lucro é intrínseco ao próprio tipo penal, ao qual está subsumida a conduta.

Se as diversas interpretações dos critérios subjetivos constantes do artigo 59 do Código Penal já causam mal estar, demandando o questionamento quanto à sua manutenção, o que dirá quando se verificam diferentes resultados de julgamentos para critérios objetivos, relacionados aos tipos penais a que os réus estão submetidos.

Os dois acórdãos colacionados mais que demonstrar que a Justiça Brasileira encontrase carente de critérios normativos de individualização e graduação das circunstancias judiciais, na fixação da pena-base, evidenciam completa irracionalidade dos julgamentos, o que implica insegurança jurídica. $^{232}$

\footnotetext{
${ }^{232}$ Tatiana de Oliveira Stoco. A Personalidade do Agente na Fixação da Pena. Dissertação de Mestrado apresentada à Universidade de São Paulo, em 2013, p. 105-106.
} 
Com referência aos casos de tráfico, que foram maioria no filtro, verificou-se em alguns que "cruzar fronteiras" para transportar a droga foi determinante para o aumento da pena-base, desvalorizando-se a personalidade do agente, por não medir esforços para obtenção de lucro.

No caso tratado pela Apelação Criminal 0002135-58.2008.4.03.6119/SP, de relatoria da Juíza Federal Convocada Silvia Rocha, da $1^{a}$ Turma, julgado em 22/11/2011, o Tribunal reformou o entendimento da juíza "a quo", que procedeu ao aumento da pena-base da ré, em razão de má avaliação da personalidade e conduta social, pela busca de lucro fácil e por cruzar fronteiras internacionais para angariar dinheiro.

Por outro lado, a menção ao motivo de lucro fácil que, segundo a magistrada de primeiro grau, é circunstância desfavorável para a traficância, integra-se ao tipo, porque a intenção de lucro é ínsita ao comportamento delituoso no caso concreto. No que tange à personalidade voltada para a prática de delitos e conduta social desfavorável, entendo que a fundamentação acostada na sentença contraria a Súmula n. 444 do STJ, de forma que se processos em andamento não podem ser considerados como maus antecedentes, conduta social reprovável e personalidade perniciosa do agente, com menos razão pode se majorar a pena com a simples menção a disposição de cruzar fronteiras internacionais para angariar dinheiro. Nesse raciocínio, diminuo a pena-base anteriormente fixada em 7 (sete) anos de reclusão, reputando adequada e suficiente o patamar de 6 (seis) anos de reclusão e 600 (seiscentos) dias-multa, um pouco acima do mínimo legal estabelecido.

Com efeito, o Tribunal, neste caso, relativamente ao motivo de lucro fácil, reconheceuo como ínsito ao fato delituoso, de forma que não tem qualquer cabimento para comportar aumento de pena, sob este argumento. Já, no que tange ao "cruzar fronteiras", da íntegra do acórdão, a conclusão a que se chegou é que o Tribunal não entendeu cabível aumentar a pena, fazendo a análise exclusiva do ponto de vista do objetivo do lucro.

Em nenhum momento, evidenciou-se que a transnacionalidade do delito já é objeto de causa de aumento de pena, prevista no artigo 40, inciso I, da Lei 11.343/06, implicando verdadeiro bis in idem a dupla punição. ${ }^{233}$

Já, na Apelação 0012884-03.2009.4.03.6119/SP, de relatoria da Desembargadora Cecilia Mello, da 2a . Turma, julgada em 29/11/2011, o Tribunal acatou a decisão do juízo $a$

\footnotetext{
${ }^{233}$ No mesmo sentindo a ACR 0010311-26.2008.4.03.6119/SP, Rel. Juíza Federal Convocada Silvia Rocha, $1^{\text {a }}$. Turma, TRF3, j. 20/03/2012.
} 
quo, que considerou desabonadoras a personalidade e conduta social do réu, pela disposição em cruzar fronteiras, nos seguintes termos:

\begin{abstract}
Na primeira fase da dosimetria da pena, o juízo a quo, atento aos ditames do art. 42, da Lei 11.343.06, fixou-a em 06 (seis) anos de reclusão. ... Considerou desabonadoras a personalidade e a conduta social do agente, de nacionalidade romena, na medida em que, ao se dispor a cruzar fronteiras em troca de numerário de pequena monta, age com desprezo à vida ordeira e frieza, a demonstrar maior danosidade social, denotando maior censurabilidade da conduta, o que impõe maior endurecimento na repressão. Quanto à culpabilidade, afirmou a sentença não ter o réu agido impulsivamente, analisando premeditadamente a conduta, tendo-se em cheque o que o motivou a cometer o crime - consistente no lucro fácil - considerando, por final, as circunstâncias e conseqüências perniciosas do ato, verificáveis com o derrame da droga no local de destino e sua indetermináveis conseqüências no seio social. Verifica-se, pois, que o magistrado elevou a pena-base considerando todos os elementos acima elencados mencionando, inclusive, a quantidade e a natureza da droga apreendida, ex vi do disposto no artigo 42, da Lei n. 11.343.06. ... Assim, entendo razoável o estabelecimento da pena-base acima do mínimo legal, nos termos acima expendidos, valendo-me dos mesmos argumentos como razão de decidir para manter a elevação da pena do tipo do artigo 33, caput, da Lei 11.343.06, em 6 (seis) anos de reclusão.
\end{abstract}

Aqui, pelas razões já expostas, entende-se que os julgadores incorreram em equívoco ao mal avaliarem a personalidade dessa forma, uma vez que o "cruzar fronteiras" é objeto da causa de aumento, prevista no artigo 40, inciso I, da Lei 11.343/06, de forma que o injusto já foi devidamente considerado, quando da fixação do percentual do aumento, entre 1/6 e 2/3. $\mathrm{O}$ mesmo se diz do lucro fácil. Primeiro, porque tal objetivo já consta do tipo, e segundo porque, como retro ponderado, nem sempre o que move o agente é qualquer tipo de lucro, mas sim a garantia da própria vida e a de seus parentes.

Outro ponto que chamou atenção foi constatar que são levados, indevidamente, em consideração, para aumento da pena-base, eventuais crimes praticados após o crime que se encontra em julgamento.

De fato, não obstante a Súmula 444 do Superior Tribunal de Justiça tenha sido editada em 28/04/2010 e publicada em 13/05/2010, e pelo seu teor, inquéritos policiais, ações penais em andamento e condenações sem trânsito em julgado, de fatos pretéritos, não possam ser considerados para caracterização de maus antecedentes, tampouco para valorar negativamente personalidade e conduta social do agente, verificou-se acórdãos proferidos posteriormente à edição e publicação da Súmula, em que não só a desconsideraram por completo, como fizeram 
a valoração equivocada, a teor da Súmula, para fatos praticados após a data do crime, que está em julgamento.

Com efeito, os crimes futuros ao crime "sub judice" foram tomados em conta para demonstrar personalidade perniciosa, delituosa, voltada a pratica de crimes, insolente, dentre outros adjetivos.

Seguem abaixo três exemplos em que os juízes de primeiro grau procederam ao aumento da pena-base, atribuindo o desvalor à personalidade dos agentes, e o Tribunal referendou, mantendo a reprimenda além do mínimo legal.

Destarte, na Apelação Criminal 0001399-04.2003.4.03.6123/SP, de relatoria do Desembargador Federal Johonsom di Salvo, da $1^{\text {a }}$. Turma, julgada em 15/06/2010, em que cuida de crime de moeda falsa e roubo, um dos réus, condenado pelos dois crimes, teve desvalorizada sua personalidade e conduta social com base em condenação por crime perpetrado posteriormente ao crime discutido nos autos, referendada em segunda instância.

Primeiramente, esclareço que a reincidência constitui circunstância agravante, a ser considerada na segunda fase de aplicação da pena privativa de liberdade, e não no momento de fixação da pena-base. Ainda, constata-se à vista da folha de antecedentes carreada aos autos (fls. 202), que o crime de roubo - frise-se: a condenação foi por crime de furto (fls. 446) - perpetrado por $\mathrm{A}^{234}$. e considerado pelo magistrado a quo para fins de reincidência, foi perpetrado em 23 de agosto de 2003, portanto, posteriormente ao fato discorrido nos presentes autos, o que impede sua consideração, até mesmo, como mau antecedente. Nesse sentido: STJ, HC 72.024/DF, Rel. Ministra Laurita Vaz, Quinta Turma, julgado em 10.06.2008, DJe 30.06.2008. Todavia, não ostenta boa conduta social e apresenta personalidade perniciosa o agente ousado insolente que, 07 (sete) meses após ter sido preso em flagrante pela prática de crime de roubo e moeda falsa, investe novamente contra $o$ patrimônio de outrem, razão pela qual mantenho a pena-base de A. em 03 (três) anos e 06 (seis) meses de reclusão.

Igualmente aconteceu no julgamento da Apelação Criminal 000079206.2006.4.03.6181/SP, de relatoria do Desembargador Federal Johonsom di Salvo, da $1^{\text {a }}$. Turma, julgada em 13/10/2009, em que também tratou do crime de moeda falsa.

\footnotetext{
${ }^{234}$ Optou-se por manter apenas as iniciais do nome para preservação de identidade, não obstante não haja segredo de justiça.
} 
Quanto à F.M de $\mathrm{O}^{235}$, à vista de sua culpabilidade acentuada, personalidade vocacionada à prática de ilícitos contra a fé pública, e conduta social incompatível com a vida comunitária, a pena-base foi fixada acima do mínimo legal, em 04 (quatro) anos de reclusão, montante que restou imutável ante a ausência de circunstâncias agravantes ou atenuantes, e, de causas de aumento ou diminuição da pena. Não preenchidos os requisitos subjetivos reclamados pelo artigo 44 do Código Penal, não foi promovida a substituição por penas restritivas de direitos. À vista das circunstâncias judiciais desfavoráveis, foi fixado o regime prisional fechado para início do cumprimento da pena detentiva. ... A sanção penal infligida é insuscetível de reparo. Com efeito, verifica-se que durante o gozo do benefício da liberdade provisória concedida no presente feito, F. foi surpreendido praticando o mesmo delito ora discorrido - guardava consigo, no bolso da calça, 12 (doze) cédulas falsas de $R \$ 50,00$ (cinqüenta reais), 10 (dez) delas com a mesma numeração de série -, donde se conclui que o citado recorrente tem como hábito a prática do crime em questão. E ainda que nos respectivos autos não exista édito condenatório - ressalta-se que em consulta via internet, apurou-se que os autos de n. 2007.61.81.004633-3 estão conclusos para a prolação da sentença - é fato inconteste que o ilustre magistrado a quo não considerou unicamente tal ocorrência para exacerbar a pena-base, mas também sopesou a culpabilidade acentuada, conduta social reprovável e personalidade perniciosa.

\section{Ainda da lavra do eminente Desembargador Federal Johonsom di Salvo, da $1^{\text {a }}$ Turma,} tem-se a Apelação Criminal 0007808-21.2000.4.03.6181/SP julgada em 17/04/2007, na qual restou mantida a sentença condenatória, pela má avaliação da personalidade do réu, em função de crime praticado após o delito dos autos.

A condenação referida na sentença, além de não poder gerar reincidência também não pode ser considerada mau antecedente, porque o próprio ato delituoso de desacato foi praticado após o período descrito na denúncia do crime do artigo 168-A do Código Penal. É lógico que só são antecedentes os episódios da vida anteacta do agente. É caso de se afastar a reincidência e o reconhecimento de maus antecedentes. Por outro lado, para a realização da Justiça, é indispensável que se analise a personalidade do agente e sua conduta pessoal (art. 59 do Código Penal). Não se pode ignorar que na ocasião em que já era réu na presente ação penal, cometeu um crime de desacato contra um oficial de justiça no momento em que legitimamente representava este Poder Estatal. Os fatos foram apurados e a ação penal culminou com o trânsito em julgado (fl. 792). A despeito de ter uma ação penal movida contra si, não teve o menor pudor em desferir palavras de baixíssimo calão contra um oficial de justiça, na confiança da impunidade. Assim, tal circunstância deve ser levada em conta como diretriz judicial para a fixação da pena-base, pois como ensina Cezar Bitencourt: "na análise da personalidade deve-se verificar a sua boa ou má índole, sua maior ou menor sensibilidade ético-social, a presença ou não de eventuais desvios de caráter de forma a identificar se o crime constitui um episódio acidental na vida do réu" (Tratado de Direito Penal, vol. 1, p. 555, Saraiva, 8 a edição)."

\footnotetext{
${ }^{235}$ Optou-se por manter apenas as iniciais do nome para preservação de identidade, não obstante não haja segredo de justiça.
} 
Nos três casos tratados acima, percebe-se que o Tribunal referendou entendimento dos magistrados de primeiro grau, validando suas justificativas da plausibilidade de desvalorização da personalidade do agente, com base em crimes posteriores.

A leitura da íntegra dos acórdãos revelou que o mote para o aumento da pena-base, pela desvalorização da personalidade foram os crimes praticados posteriormente aos fatos que estavam em julgamento, não havendo qualquer outra circunstância desfavorável a nenhum dos réus.

Os fatos ocorridos após o delito em julgamento não podem ser considerados para valoração do artigo 59 do Código Penal, por implicar bis in idem, uma vez que o réu que teve sua pena-base aumentada indevidamente, com fulcro em fatos posteriores; quando do julgamento destes, terão considerados em seu desfavor os fatos anteriores, seja a título de maus antecedentes, seja a título de reincidência, a depender do caso. O que leva a uma dupla penalidade.

Esta constatação permite concluir que não há nada certo no campo da fixação da penabase, permanecendo os jurisdicionados reféns de todo tipo de elucubração dos julgadores, que a seu bem entender, ditam o que pertence ao espectro da aplicação das penas, sem qualquer possibilidade de controle de suas decisões.

Ademais, há que se dizer que se a Súmula 444 do Superior Tribunal de Justiça impede que inquéritos policiais, ações penais em curso, e até condenações sem trânsito em julgado de casos pretéritos, sejam considerados para se caracterizar maus antecedentes, ou desvalorizar a personalidade e conduta social, dos agentes, em homenagem ao princípio da presunção de inocência, o que dizer dos fatos futuros?

No mínimo, a mesma justificativa para se valer a Súmula para casos pretéritos deve ganhar ainda mais força para repudiar a valoração de casos de crimes futuros.

Ainda com referência à consideração de crimes futuros para o aumento da pena-base, citam-se abaixo dois casos, em que os magistrados de primeiro grau fixaram a pena acima do mínimo legal, porém o Tribunal reformou o entendimento.

Estes casos, não obstante demonstrem o entendimento acertado do Tribunal em não validar as sentenças monocráticas, o que por si só já ensejaria sua inclusão no presente 
trabalho, para evidenciar o contraponto ao exposto nos três acórdãos acima; foram também escolhidos para exemplificar a situação de fragilidade da fixação da pena ainda na primeira instância, na medida em que restou claro a inexistência de critério na fixação das penas, cuja semelhança dos casos jamais demandaria a distinção das reprimendas.

Com efeito, em ambos, o crime em julgamento era o de circular moeda falsa, sendo que a apreensão foi de apenas uma nota falsa de $\mathrm{R} \$ 50,00$, fixando-se a pena-base além do mínimo, pela desvalorização da personalidade dos agentes, em razão de crimes futuros.

Na Apelação Criminal 0002143-19.2003.4.03.6181/SP, de relatoria do Desembargador Federal Cotrim Guimarães, da $2^{\mathrm{a}}$. Turma, julgada em 15/05/2012, a Ré foi condenada, pelo MM Juízo "a quo", a 4 (quatro) anos de reclusão, em regime semi aberto, e ao pagamento de 48 dias-multa, à razão de 1/30 do salário mínimo vigente, não tendo sua pena corporal substituída por restritivas de direito, justamente pela consideração da personalidade voltada à prática de crimes.

\footnotetext{
Nesta apelação, trata-se de caso em que a Ré foi condenada a 4 (quatro) anos de reclusão, em regime semi aberto, e ao pagamento de 48 (quarenta e oito) dias-multa, cada qual à razão de 1/30 do salário mínimo vigente, pelo crime previsto no artigo 289, parágrafo primeiro, do Código Penal, por ter no dia 19.08.2002, introduzido em circulação uma cédula falsa de $\mathrm{R} \$ 50,00$ no Mercado Liu Ltda., tendo a juíza de primeira instância procedido ao aumento de sua pena-base, com fundamento em condenação com trânsito em julgado de feito ocorrido após o cometimento do delito sob julgamento, concluido que sua personalidade era propensa à prática de crime, deixando, inclusive, de substituir a reprimenda corporal por penas restritivas de direito, por entender que as circunstâncias judiciais não a tornavam recomendável.
}

O Tribunal reformou a sentença, mencionando sólida orientação do Superior Tribunal de Justiça, quanto à impossibilidade de caracterização de personalidade desabonadora ou de má conduta social com base em condenação por fatos posteriores aos descritos na denúncia, ainda que tenha ocorrido o seu trânsito em julgado. E diminuiu a pena para 3 (três) anos de reclusão, 10 (dez) dias-multa, calculadas sobre o valor mínimo unitário. Determinou, outrossim, a substituição da pena privativa de liberdade por duas restritivas de direito, sendo uma de prestação de serviços comunitários e outra pecuniária no valor de 5 (cinco) salários mínimos. Segue trecho do acórdão. 
Cumpre observar, entretanto, que há sólida orientação do colendo Superior Tribunal de Justiça quanto à impossibilidade de caracterização de personalidade desabonadora ou de má conduta social com base em condenação por fatos posteriores aos descritos na denúncia, ainda que tenha ocorrido o seu trânsito em julgado. Confira-se: HABEAS CORPUS. ROUBO. PENA-BASE ACIMA DO MÍNIMO LEGAL SEM SUFICIENTE FUNDAMENTAÇÃO. PROCESSOS EM CURSO. PRESUNÇÃO DE INOCENNCIA. CONDENAÇÃO TRANSITADA EM JULGADO REFERENTE A FATO POSTERIOR À DENÚNCIA. 1. Conforme jurisprudência desta Corte, inquéritos ou ações penais em andamento não podem ser levados em conta para efeito de fixação da pena-base acima do mínimo legal, ainda que a título de "personalidade voltada a prática de crimes" ou de "má conduta social", em respeito ao princípio da presunção de inocência. 2. Não se admite, no estabelecimento da pena-base, a valoração de condenações transitadas em julgado referentes a fatos posteriores aos indicados na denúncia. 3. A circunstância de o paciente não haver eventualmente comprovado o exercício de atividade laboral não pode militar em seu desfavor na dosimetria da pena, por falta de amparo legal e constitucional, até porque o fato de estar desempregado não traduz conduta ilícita. 4. Ordem concedida para para reduzir a sanção do paciente de 4 (quatro) anos e 8 (oito) meses de reclusão e 11 (onze) dias-multa para 4 (quatro) anos de reclusão, no regime aberto, e 10 (dez) dias-multa. (STJ, Sexta Turma, HC 127096, Relator Ministro Og Fernandes, DJ 14/12/2009) HABEAS CORPUS. ROUBO TRIPLAMENTE CIRCUNSTANCIADO (ART. 157, \& 2o., I, II E V DO CPB). DOSIMETRIA DA PENA. PENA BASE ACIMA DO MÍNIMO LEGAL: 7 ANOS E 9 MESES DE RECLUSÃO. REGIME INICIAL FECHADO. MAUS ANTECEDENTES, PERSONALIDADE E CONDUTA SOCIAL NEGATIVAMENTE VALORADAS COM BASE EM INQUÉRITOS E AÇÕES PENAIS EM CURSO E CONDENAÇÃO TRANSITADA EM JULGADO POR CRIME POSTERIOR. CONSTRANGIMENTO ILEGAL EVIDENCIADO. PRECEDENTES DO STF E STJ. RESSALVA DO ENTENDIMENTO DO RELATOR. UTILIZAÇÃO DE DUAS CAUSAS DE AUMENTO COMO CIRCUNSTÂNCIAS JUDICIAIS NEGATIVAS E UMA NA TERCEIRA FASE DA DOSIMETRIA DA PENA. OPERAÇÃO QUE REDUNDOU EM ACENTUADO PREJUÍZO PARA O RÉU. PENA REDIMENSIONADA: PENA BASE FIXADA EM 5 ANOS DE RECLUSÃO, AUMENTADA DE 1/3, EM RAZÃO DA RESTRIÇÃO À LIBERDADE DA VÍTIMA, TOTALIZANDO 6 ANOS E MESES DE RECLUSÃO, EM REGIME INICIAL FECHADO. PARECER DO MPF PELA DENEGAÇÃO DA ORDEM. ORDEM PARCIALMENTE CONCEDIDA, PARA O FIM ACIMA ESPECIFICADO. 1. Segundo pacífico entendimento desta Corte e do colendo STF, ações penais em andamento ou inquéritos penais em curso ou por fatos cometidos posteriormente aos em exame, bem como condenações transitadas em julgado por fatos posteriores ao exposto na denúncia não podem subsidiar o aumento da pena base a título de maus antecedentes, má personalidade ou conduta social inadequada. 2. Esta Corte tem considerado ausente constrangimento ilegal quando, constatada mais de uma causa de aumento no crime de roubo, algumas forem utilizadas como circunstâncias judiciais desfavoráveis e outras para aumentar a reprimenda na terceira fase. (...) 5. Parecer do MPF pela denegação da ordem. 6. Ordem parcialmente concedida, para o fim de refazer o apenamento do paciente, como acima especificado. (STJ, Quinta Turma, HC 135502, Relator Ministro Napoleão Nunes Maia Filho, DJ 30/11/2009). Deste modo, ausente qualquer circunstância judicial desfavorável, fixo a pena-base em 3 (três) anos de reclusão, a qual, à míngua da circunstâncias agravantes e atenuantes, ou de causas de aumento ou de diminuição de pena, torna-se definitiva. Proporcionalmente, reduzo a pena de multa para 10 (dez) dias-multa, calculados sobre o valor mínimo unitário. Diante da inexistência de circunstância contraindicativa dentre os critérios do art. 59 do Código Penal, fixo o regime aberto de cumprimento de pena. Pelos mesmos motivos, entendo que não está configurado o requisito obstativo da conversão da pena privativa de liberdade em restritivas de direitos previsto n o art. 44, III, do Código 
Penal. Destarte, presentes as demais condições para a concessão do benefício, determino que a pena privativa de liberdade seja substituída por duas penas restritivas de direitos, sendo uma consistente em prestação de serviços à comunidade ou a entidade com destinação social, na forma disposta no art. 46 , $\S 3^{\circ}$, do Código Penal, e a outra de prestação pecuniária, no importe de 05 (cinco) salários mínimos, ambos em favor de entidade pública ou privada com destinação social, a ser designada pelo Juízo das Execuções.

Já na Apelação Criminal 0008484-19.2004.4.03.6119/SP, de relatoria do Juiz Convocado Márcio Mesquita, 1 ${ }^{\text {a }}$. Turma, julgada em 22/01/2013, tal qual o caso acima, o réu foi condenado pelo crime de moeda falsa, por fazer circular cédula falsa de $\mathrm{R} \$ 50,00$ (cinqüenta) reais. No entanto, sua pena-base foi fixada acima do mínimo legal, em 3 (três) anos, 7 (sete) meses e 6 (seis) dias de reclusão e 12 (doze) dias multa, levando-se em consideração a conduta social desvirtuada e personalidade voltada para o cometimento de delitos, em razão de haver condenações com trânsito em julgado, porém cujos fatos são posteriores ao cometimento do delito em julgamento.

Após a reforma da sentença pelo Tribunal, redimensionou-se a pena final em 3 (três) anos de reclusão e 10 (dez) dias multa, no valor de 1/30 (um trigésimo) do salário mínimo, substituindo-se a pena privativa de liberdade por duas restritivas de direito, sendo uma de prestação de serviços à comunidade e outra pecuniária no valor de 1 (um) salário mínimo.

Da leitura da íntegra dos acórdãos, com riqueza de detalhes sobre as sentenças monocráticas, e as razões que os magistrados desposaram para proceder ao aumento da penabase, pode-se afirmar inexistir qualquer peculiaridade de um e outro caso, que demandasse a diferença da reprimenda aplicada.

No primeiro, a ré além de ter fixada sua pena privativa de liberdade com cinco meses a mais, também foi prejudicada com mais dias multa, além da fixação de regime mais gravoso, e da impossibilidade de substituição.

Outro caso que evidencia a falta de parâmetro objetivo é o da Apelação Criminal 2000.03.99.057564-9/SP, de relatoria do Juiz Federal Convocado Manoel Álvares, da $2^{\mathrm{a}}$ Turma, julgada em 20/03/2001, que tratou de roubo majorado pelo emprego de arma de fogo e concurso de agentes, em que o réu teve aumentada sua pena-base, por revelar maior periculosidade, uma vez ter demonstrado personalidade voltada à prática de crimes pela 
violência, e sublinhe-se, pelas circunstâncias do crime, que no caso, seriam o uso de arma de fogo e concurso de agentes.

\begin{abstract}
$\mathrm{V}-\mathrm{O}$ conjunto probatório indica ter o agente a personalidade voltada à prática de crimes, bem como que as circunstâncias do crime (uso de arma de fogo e concurso de agentes) exigem uma reprimenda maior, pois o todo demonstra sua alta periculosidade. ... VIII - O regime inicial de cumprimento de pena depende não só da quantidade de pena, mas também das circunstâncias judiciais, conforme os critérios previstos no artigo 59 do $\mathrm{CP}$ (parágrafo $3^{\circ}$, do artigo 33 , do $\mathrm{CP}$ ). Não basta a presença dos requisitos objetivos como primariedade do agente a pena não exceder a 8 anos para fazer "jus" ao regime mais brando. A concessão de regime mais favorável depende também da análise apurada dos requisitos de ordem subjetiva que, consoante todo o conjunto probatório, demonstram ter o réu a personalidade voltada à prática de crimes caracterizados pela violência, o que revela sua maior periculosidade, a justificar o início do cumprimento da pena no regime fechado.
\end{abstract}

Neste caso, o próprio elemento do crime de roubo, que é a violência, foi considerado para avaliação de uma suposta periculosidade do réu, com consequente aumento da pena-base. Além disso, foram tomadas como circunstâncias do crime, justificando a pena-base acima do mínimo legal, o emprego de arma de fogo e o concurso de agentes, que já constituem causas de aumento de pena, nos termos do artigo 157, parágrafo $2^{\circ}$, incisos I e II, do Código Penal.

Parece que, na impossibilidade de se aferir em que consiste a personalidade do agente, tomam-se, indevidamente, como critérios, os próprios elementos do tipo para tanto.

Importante esclarecer que o estudo da jurisprudência não pretendeu fazer críticas à atuação dos julgadores, cuja atividade árdua e solitária ${ }^{236}$ demanda reverência. Tampouco buscou-se diagnosticar o status da fixação da pena-base no Brasil. Na verdade, quis-se com essa análise demonstrar que a atividade de julgar, humana por natureza, ressente-se, como não

\footnotetext{
236 “A solidão é companheira do juiz brasileiro de primeiro grau. Culturamente treinado a julgar sozinho, ouvindo apenas a sua consciência, vai sendo empurrado a sozinho permanecer. Enquanto em outras carreiras - Ministério Público, por exemplo - é natural o espírito gregário, a função judicial estimula o isolamento. Pois o juiz não deve discutir com ninguém o ato de julgar. Precisa estar imune a qualquer influência nociva." (José Renato Nalini. Perspectivas da Justiça e do Juiz no limiar do Século XXI. Tese de doutoramento apresentada à Universidade de São Paulo, em 2000, p. 69). No mesmo sentido, Miguel Reale Júnior ao dispor que: "o juiz não apenas preside a produção da prova, mas a valora, e o faz muitas vezes no próprio instante em que conduz a sua realização, seja dirigindo o interrogatório ou colhendo o testemunho por meio de perguntas direcionadas em determinado sentido, no que se afasta da imparcialidade científica do historiador. Se há contraditório, com a participação das partes e o entrechoque de opiniões, a ponto de considerar Ferrajoli que a avaliação cruzada da prova torna o julgamento um psicodrama, na verdade, há, como em bela página destacou Carnelutti, o momento de decisão como um instante de silêncio, de diálogo do julgador consigo mesmo." (Miguel Reale Júnior. Razão e subjetividade no direito penal. Ciências Penais, São Paulo, ano 1, n. 00, 2004, p. 231). (destaques nossos).
} 
poderia deixar de ser, de todo tipo de falha, a final de contas, os julgamentos não são feitos por máquinas, computadores, onde se colocam os dados do caso, e com o aperto de um botão, se chega à pena. Não, trabalha-se com gente, e como tal, passível de erro.

As divergentes formas de julgar verificadas nos julgados estudados apenas vêm referendar a impossibilidade da manutenção de critérios subjetivos, na fixação da pena-base, uma vez que até quanto aos critérios objetivos não há isonomia nos julgamentos, demonstrando-se a imperfeição do ser humano.

Se com relação às circunstâncias objetivas, o subjetivismo ficou mais que constatado, no que diz respeito às circunstâncias subjetivas, a situação resta ainda mais frágil.

Com efeito, conforme apontado no início, o corte traçado para a pesquisa jurisprudencial, efetuado pelas palavras "Fixação da pena e conduta social e personalidade", trouxe julgados havidos dentre o período de 11/12/1995 a 25/06/2013.

Nesse espectro de quase 20 anos, percebeu-se que um ato específico causou mais dificuldades aos julgadores quanto ao que considerar para avaliar a personalidade e conduta social do agente de forma desfavorável.

Tal fato foi justamente a edição da Súmula 444 do Superior Tribunal de Justiça, em 28/04/2010, com publicação em 13/05/2010.

Este marco teve impacto profundo nas decisões, podendo-se, inclusive, arriscar dizer que os conceitos de personalidade e conduta social atribuídos aos réus até então, após a Súmula, ficaram completamente esvaziados, ou demandaram maior dificuldade para fundamentar.

A análise dos julgados ocorridos antes da Súmula demonstra que a personalidade negativa e a má conduta social, e aí se entenda todo tipo de adjetivo possível, como "perniciosa, indolente, com poucos freios, arrogante, antissocial, delituosa, e etc", pautavamse, quase que completamente, na valoração dos apontamentos constantes das fichas de antecedentes dos réus.

Então, a presença de inquéritos policiais, processos em andamento, atos infracionais e condenações sem trânsito em julgado, eram valorados negativamente também a título da personalidade e conduta social. Seguem alguns exemplos. 
III - Correta a fixação da pena-base acima do mínimo legal, se o réu é portador de maus antecedentes, em cuja extensa folha constam vários envolvimentos em delitos, reveladoras de personalidade voltada à prática de delitos. ${ }^{237}$

IV - Os antecedentes integram o elenco de circunstâncias judiciais norteadoras da fixação da pena-base. No caso, o apelante possui vários inquéritos policiais instaurados contra si, bem como processos em andamento, o que revela não apenas seus maus antecedentes, como também sua personalidade voltada à prática de crimes e má conduta social. Inteligência do artigo 59 do Código Penal. ${ }^{238}$

A sentença guerreada fixou, com acerto, a pena-base do apelante acima do mínimo legal, tendo em vista a sua conduta social e a sua personalidade vocacionada para a prática de ilícitos contra o patrimônio (folha de antecedentes - fls. 199/208), além de seus maus antecedentes, já tendo o recorrente suportado duas condenações definitivas por roubo, como se verifica das certidões criminais de fls. $150 / 151 .^{239}$

Mesmo nos casos em que já se falava, expressamente, da impossibilidade de tais apontamentos serem tomados como maus antecedentes, por conta do princípio da inocência, eram levados em consideração na análise negativa da personalidade e conduta social.

1 - A consideração de maus antecedentes para elevação da pena-base e o acréscimo pela reincidência apenas configura "bis in idem" se tiverem a mesma origem (mesma condenação). Pena-base corretamente elevada em razão de conduta social reprovável, derivada de inquéritos policiais e ações penais em curso, e exasperação pela reincidência efetivamente caracterizada. ${ }^{240}$

Excetuando-se os casos, em que houve, de fato, erro na fixação da pena, pela interpretação equivocada dos critérios objetivos, consoante demonstrado pelos diversos exemplos de julgados, citados ao longo deste capítulo, temos que antes da Súmula 444, a

${ }^{237}$ Apelação Criminal 0816830-32.1984.4.03.6181/SP, Rel. Des. Fed. Theotonio Costa, $1^{\mathrm{a}}$ Turma, TRF3, j. 15/05/1996.

${ }^{238}$ Apelação Criminal 0026481-82.1988.4.03.6181/SP, Rel. Des. Fed. Theotonio Costa, $1^{\mathrm{a}}$ Turma, TRF3, j. $17 / 11 / 1998$.

239 Apelação Criminal 0001025-47.1999.4.03.6181/SP, Rel. Juiz Fed. Convocado Hélio Nogueira, 5 Turma, TRF3, j. 21/11/2000.

${ }^{240}$ Apelação Criminal 0002762-54.2001.4.03.6104/SP, Rel. Des. Fed. Marisa Santos, da $2^{\mathrm{a}}$ Turma, TRF3, j. 25/03/2003. 
personalidade e a conduta social eram averiguadas, quase que exclusivamente, com base na folha de antecedentes do réu.

Nos casos julgados anteriormente à edição/publicação da Súmula, não houve interesse dos julgadores em buscar elementos na vida pregressa dos réus, que pudessem balizar a fixação da pena-base acima do mínimo, com fundamento na conduta social ou personalidade.

Quando existiu o aumento da pena-base por conta dessas duas circunstâncias judiciais, foi feito, quase sempre, por se transferir a desvalorização dos apontamentos criminais dos réus à análise de sua personalidade, como voltada ao crime ou à conduta social desfavorável.

Tem-se que, de um modo geral, antes da Súmula, somente a vida pregressa "criminosa" dos réus era considerada pelos julgadores para avaliar negativamente a personalidade e conduta social. Bastava ter inquéritos policiais e ações penais em andamento, para ensejar o rótulo de personalidade voltada ao crime.

\begin{abstract}
Não encontro, na reprimenda imposta, qualquer exacerbação não justificada. Reputo correta a fixação da pena-base do apelante acima do mínimo legal, visto que, consoante justificou o MM. Juiz "a quo", deveria agora ser considerado como portador de péssimos antecedentes, não sendo o presente um fato isolado em sua vida, tendo em vista a quantidade de condenações ainda não transitadas em julgado, que revelam ter optado pela prática criminosa, bem como outras condenações já passadas em julgado, posteriores à prática dos fatos delituosos de que tratam os presentes autos ... Quanto às condenações posteriores, já transitadas em julgado, apenas vêm reforçar a certeza moral de que a personalidade do apelante é voltada ao crime. $^{241}$
\end{abstract}

Não obstante, citam-se abaixo alguns poucos casos, em que a personalidade e/ou conduta social foram mal avaliadas, de forma autônoma à existência dos, na época, considerados antecedentes dos réus.

Com efeito, na Apelação Criminal 0100644-28.1991.4.03.6181/SP, de relatoria da Desembargadora Federal Cecília Mello, da $2^{\text {a }}$ Turma, julgada em 25/03/2008, o Tribunal deu provimento ao recurso do Ministério Público, e reformando sentença absolutória, condenou o réu, pelo crime do artigo $3^{\circ}$, inciso II, da Lei 8.137/90, decretando-lhe, ainda, a perda do cargo público que ocupava.

${ }^{241}$ Apelação Criminal 2001.03.99.044278-2/SP, Rel. Des. Fed. Marisa Santos, $2^{\mathrm{a}}$ Turma, TRF3, j. 22/04/2003. 
Depreende-se do acórdão que a exasperação da pena-base do réu fundamentou-se na valorização negativa de sua conduta social e personalidade, por auditor da Receita Federal do Brasil, pessoa, que pela profissão, teria a incumbência de fiscalizar o cumprimento dos tributos, e não se envolver em crime, solicitando dinheiro, para não fazer o seu dever.

Além disso, os julgadores apegaram-se, igualmente, às transcrições da fita, que gravou o momento da solicitação, para justificar que o réu seria pessoa com grande desenvoltura, demonstrando familiaridade com o assunto, não sendo, portanto, principiante.

Na primeira fase de fixação da pena, entendo existirem motivos bastante razoáveis para justificar a exasperação da pena. Muito embora não existam antecedentes desfavoráveis a serem considerados, é de se notar que a degravação das conversas demonstra ser o réu pessoa com bastante facilidade em abordar o assunto ora sub judice. Com o desvelar da conversa, principalmente o trecho acostado à fl.09/11 dos autos, haure-se que o réu conduz o diálogo com bastante desenvoltura e familiaridade, não demonstrando nervosismo ou insegurança de principiante. Além disso, trata-se de um Auditor da Receita Federal do Brasil, o mais alto cargo na carreira e melhor remunerado na escala hierárquica. É responsável, entre outras atribuições, pela fiscalização dos tributos federais e, mesmo assim, envolveu-se com a solicitação de valor considerável, de US\$ 50.000,00 (cinquenta mil dólares) para deixar de praticar ato de ofício. Todos esses fatores, que levam avaliação negativa da conduta social ou da personalidade do réu, não podem ser desconsiderados e conduzem à fixação da pena-base em 05 anos de reclusão e em 100 (cem) dias multa.

Este caso é um bom exemplo para demonstrar que quando os julgadores conseguem descolar a análise da personalidade e conduta social dos "antecedentes" do réu, ainda assim, não encontram solução exitosa para a definição dessas duas circunstâncias judiciais.

No caso em questão, inacreditavelmente, a elevação da reprimenda foi promovida, com base na própria circunstância elementar do crime.

O réu foi condenado pelo delito previsto no artigo $3^{\circ}$, inciso II, da Lei 8.137/90, que trata dos crimes funcionais contra a ordem tributária. $\mathrm{O}$ fato de ele ser auditor da Receita Federal do Brasil é condição sine qua non do crime.

Dessa forma, revela-se bis in idem o aumento da pena-base, porque o réu era auditor da Receita Federal, na medida em que ele respondeu ao processo crime, justamente por ter esta profissão.

Trata-se de uma situação tipicamente kafkaniana, na qual o réu responde pelo crime por ser funcionário público, e por esta condição, tem sua pena-base aumentada. 
Ademais, agravar a represália do réu, com base em sua desenvoltura, sugerindo não ser principiante é afastar-se completamente da culpabilidade do fato, deixando influenciar-se pelas condições pessoais do autor.

Outro julgado digno de nota, por mostrar até que ponto vai o arbítrio dos julgadores, é tratado na Apelação Criminal 2004.03.99.032406-3/SP, relatada pelo Desembargador Federal Cotrim Guimarães, da $2^{\text {a }}$ Turma, cujo julgamento se deu no dia 15/04/2008.

O réu foi preso em flagrante e denunciado pela prática dos delitos previstos nos artigos 304 c/c 297 e 334, alínea "d”, do Código Penal e artigo 16 da Lei no 6.368/76, por ter sido surpreendido, em sua residência, com pequena quantidade de cocaína e diversas mercadorias estrangeiras sem documentação fiscal e cédulas de identidade RG e CIC falsas em nome de H. C. H. ${ }^{242}$.

Em primeira instância, foi condenado pelo delito de uso de documento falso, previsto no artigo 304 do Código Penal, tendo sido absolvido da imputação do crime constante do artigo 334 do mesmo diploma legal, e declarada extinta a punibilidade em relação ao previsto no artigo 16, da Lei 6.368/76.

O Procurador da República recorreu da sentença, atacando apenas a fixação da reprimenda, a qual postulou o aumento; não objetou a declaração da extinção da punibilidade relativa ao porte de entorpecentes, tampouco questionou o decreto absolutório relativo ao crime do artigo 334 do Código Penal.

No entanto, ao postular pelo aumento da pena, deduz em seu pleito recursal que a pena-base deveria ter sido fixada acima do mínimo legal, porque o magistrado sentenciante teria limitado sua análise a primariedade e aos antecedentes do réu, não levando em conta, no entanto, fartos elementos nos autos, a demonstrar conduta social reprovável (uso de entorpecentes) e personalidade voltada ao crime (posse de diversas mercadorias desacompanhadas de documentação legal, utilização das mercadorias no comércio ambulante, e por descumprir as condições estabelecidas para o gozo da liberdade provisória).

Importante chamar atenção que o Ministério Público Federal, não obstante tenha deixado de apelar com relação à declaração da extinção da punibilidade do crime do artigo 16,

\footnotetext{
${ }^{242}$ Os nomes dos envolvidos foram suprimidos, mantendo-se somente as iniciais, não obstante não haja sigilo judicial.
} 
da Lei 6.368/76, e da absolvição do réu, quanto ao delito previsto no artigo 334 do Código Penal, o que, por si só, retiraria a possibilidade de o Tribunal manifestar-se a esse respeito, pleiteou o aumento da pena referente ao crime de uso de documento falso, com fulcro no porte de drogas para uso próprio e no descaminho, que não resultaram em condenação.

Não existia o menor cabimento para pleito de tal natureza, na medida em que um fato explicitamente apreciado, que não resultou em condenação, não pode ser usado para justificar a aplicação da pena-base acima do mínimo legal.

No entanto, o Tribunal acolheu o quanto requerido pelo órgão acusador, e promoveu o aumento da pena-base do réu, com o seguinte fundamento:

\begin{abstract}
No tocante à fixação da pena-base, assiste razão ao Ministério Público Federal. Embora primário e sem antecedentes criminais, a conduta social, a personalidade do réu e as demais circunstâncias judiciais permitem que a pena-base seja fixada acima do mínimo legal. O próprio acusado, por ocasião de seu interrogatório, afirmou que vendia canetas, facas, perfumes e roupas adquiridas na Avenida Vinte e Cinco de Março, esclarecendo que não possuía nota fiscal porque se tratavam de peças do seu mostruário. Na ocasião, as mercadorias apreendidas foram levadas em dois carros de polícia. Assim, os elementos constantes dos autos indicam para a prática de comércio ambulante de mercadorias estrangeiras introduzidas clandestinamente no país, conduta social reprovável. (fls. 286/288) Outro fator que deve ser considerado, com o temperamento devido, consiste na guarda de substância entorpecente. Sem que isto implique em julgamento pelo fato em si mesmo, que foi atingido pela prescrição da pretensão punitiva estatal, não se pode perder de vista que tal conduta é socialmente reprovável, tanto que, mesmo após o advento da Lei no 11.343/03, cujo artigo 28 não prevê pena privativa de liberdade, continua sendo criminosa.
\end{abstract}

Ao promover o aumento da pena-base, com fulcro em fatos devidamente analisados em primeira instância, e afastados de decreto condenatório, seja porque colhidos pela prescrição, seja por que entendidos como não criminosos, o Tribunal incorreu em severo equívoco.

Ademais, a despeito do erro técnico do julgamento, o acórdão revelou algo ainda pior, na medida em que transparecendo o preconceito em relação ao usuário de drogas, rotulado como portador de conduta reprovável, impingiu-lhe penalização mais dura, unicamente pelo seu modo de ser.

Retomando os julgados posteriores à Súmula 444 do STJ, pode-se dizer que a maioria acolheu seu entendimento, sendo certo que, em alguns poucos casos, ela foi excepcionada, inclusive, expressamente. 
A caracterização da personalidade e conduta social, a partir de então, pautou-se nas próprias condições do crime, acreditamos, até para disfarçar a real motivação.

A bem da verdade, o que se depreendeu dos julgados estudados é que depois da Súmula, os julgadores tiveram mais trabalho para justificar a fixação da pena-base acima do mínimo legal, pois, ainda que de forma velada, o real motivo desse aumento eram os "antecedentes". Como não mais se pode falar expressamente em inquéritos e processos em andamento, na primeira fase da aplicação da pena, passa-se a mencionar: a audácia de fraudar a autarquia, por tantas vezes; a enorme quantidade de notas falsas apreendidas a revelar personalidade sem travas morais, dentre outros.

Na Apelação Criminal 0002558-70.2001.4.03.6181/SP ${ }^{243}$, julgada em 07/02/2012, que tratou do crime previsto no artigo 171, parágrafo $3^{\circ}$, do Código Penal, o motivo do aumento da reprimenda, na primeira fase, foi a existência de apontamentos criminais na ficha do réu. No entanto, em função da vedação da Súmula 444, procurou-se embasamento em outras circunstâncias, tais como a ousadia na empreitada criminosa e a desenvoltura profissional utilizada na fraude.

4. Nos moldes da súmula 444 do Superior Tribunal de Justiça mister reconhecer que não ensejam a exasperação da pena-base inquéritos policiais e ações penais em curso em virtude do princípio constitucional da presunção de inocência. Mas é forçoso convir que, no caso, a pena-base restou fixada acima do mínimo legal por serem desfavoráveis ao acusado as circunstâncias judiciais previstas no artigo 59 do Código Penal, não somente diante da extensa folha de antecedentes do réu, demonstrando que possui personalidade voltada à prática de crime de estelionato, condenado pelo cometimento de crime da mesma espécie ao narrado na peça acusatória, como também pelo o alto grau de reprovabilidade da conduta, ante a desenvoltura profissional utilizada nas fraudes previdenciárias e pela utilização ilícita de documentos que estavam sob sua guarda. 5. As considerações relativas às circunstâncias judiciais destacadas na sentença demandaram análise detida da conduta do acusado, restando salientada sua ousadia na empreitada criminosa, bem assim sua personalidade sem travas morais. Assim, a discricionariedade conferida ao julgador pela norma penal dentro do processo global de fixação da sanção corporal autoriza concluir que a majoração da pena-base acima do mínimo legal, afigura-se suficiente para a reparação do delito.

${ }^{243}$ Apelação Criminal 0002558-70.2001.4.03.6181/SP, Rel. Juíza Federal Convocada Raquel Perrini, $1^{\text {a }}$ Turma, j. 07/02/2012. 
Há um caso digno de nota, o da Apelação Criminal 0005886-82.2010.4.03.6119/SP ${ }^{244}$, em que o Tribunal reformou a sentença de primeiro grau, para reduzir a pena base ao mínimo legal. A apelante havia sido condenada por tráfico internacional de entorpecentes, sendo certo que a pena não fora aplicada no mínimo, em virtude de ela ter, ao ver do magistrado, conduta social reprovável, uma vez que não cuidava dos filhos.

Acertado o entendimento do Tribunal, na medida em que afastou o aumento, primeiramente, porque nada nos autos evidenciava que a mãe negligenciava o cuidado com seus filhos. E, em segundo lugar, com todo respeito, ainda que a condenada não cuidasse dos filhos, o Estado não poderia levar tal fato em conta, em um julgamento referente ao tráfico de entorpecentes, sob o risco de, mais uma vez, punir-se o cidadão pelo que ele é, e não pelo que ele fez.

10. Relativamente à conduta social, afirmou-se que pesa em seu desfavor o fato não ter dispensado os cuidados necessários aos seus cinco filhos. A conclusão não se afigura plausível, porquanto a ré esclareceu no interrogatório que seus três filhos mais velhos estudavam e que eles ficaram aos cuidados da sua mãe após sua prisão. Por outro lado, além de suas declarações, nenhuma prova foi produzida no sentido de que a acusada não cumpria satisfatoriamente seu papel no contexto familiar, não obstante a atividade delituosa versada nestes autos.

Poder-se-ia continuar discorrendo acerca dos casos analisados; entretanto, entende-se que, do universo estudado, pinçaram-se aqueles mais ilustrativos. Tudo com o objetivo de evidenciar que, mesmo depois de uma Súmula publicada com o fim de reduzir o subjetivismo na aplicação da pena, a existência das circunstâncias judiciais da personalidade e da conduta social continua a permitir o Direito Penal de autor nos Tribunais pátrios.

A bem da verdade, o estudo feito evidencia que sequer é possível garantir que eventual exclusão de tais circunstâncias do ordenamento garantiria menor subjetivismo, pois, como visto, em muitos casos, tal subjetivismo vem travestido na condição de circunstância do crime.

Ainda que o estudo revele a falta de segurança jurídica das decisões judiciais até na avaliação de critérios objetivos, o que se poderia concluir pela impossibilidade de afastar a subjetividade dos julgadores em suas decisões; não é possível fechar os olhos para o fato de

${ }^{244}$ ACR 0005886-82.2010.4.03.6119/SP, Rel. Des. Fed. Ramza Tartuce, $5^{\mathrm{a}}$ Turma, j. 03/09/2012. 
que a permanência das circunstâncias conduta social e personalidade, subjetivas por sua natureza, incrementa o risco de decisões contaminadas por juízos moralizantes, na medida em que pautadas em parâmetros francamente vagos e imprecisos, além de conferir aos julgadores um supremo poder de gestores da moral.

Se as premissas da Lei Maior imprimem os valores da secularização, não há como conferir aos julgadores ampla faculdade para determinarem quem é bom e quem é mau, em critérios morais. Mais, se o princípio da legalidade expressa que não há crime, sem lei anterior que o preveja; não há como aceitar a fixação de pena acima do mínimo legal, em função da avaliação do julgador sobre a forma de autodeterminação da vida do agente, sem concluir por total afronta aos preceitos constitucionais.

Além do que, conforme dispõe Gabriel Antinolfi Divan:

\begin{abstract}
Não custa, ainda, filosofar acerca do fato de que, se é capaz, o julgador, de gerir a índole do réu a partir de severos juízos paternais (analogia mais do que bem vinda neste caso) de valor em meio à decisão (no caso, a sentença, através dos conceitos tradicionais sobre os meandros significativos do Artigo 59 em questão), é porque ele detém a ordem dos padrões morais necessários à sociedade. Não é passível de ser avaliador das "qualidades" de índole de uma pessoa quem não esteja (ou não se visualize) acima delas e creia ter, delas, perfeita noção não deturpada. O julgador penal, nessa óptica, se arvora da condição de proprietário da cartilha social de bons modos. E de uma Razão mais esclarecida. ${ }^{245}$
\end{abstract}

Seja por entender que somente pelos preceitos constitucionais, tais circunstâncias já deveriam ter sido abolidas do ordenamento jurídico, seja por acreditar que os juízes não estão acima do bem e do mal, conforme melhor será esclarecido no próximo capítulo, é que entendemos urgente a retirada da conduta social e da personalidade do artigo 59 do Código Penal.

\footnotetext{
${ }^{245}$ Gabriel Antinolfi Divan. Decisão judicial nos crimes sexuais: o julgador e o réu interior. Porto Alegre: Livraria do Advogado Editora, 2010, p. 154.
} 


\title{
4 O JULGADOR
}

\begin{abstract}
A grandeza do direito não está na sua certeza, como universalidade e previsibilidade, inalcançáveis, mas na busca incessante do justo, em uma tarefa sujeita a todas as contingências, às condicionantes do conhecimento e dos juízos de valor, de ordem pessoal, cultural, social, pois, por mais solene que o Judiciário seja, ao se revestir de pompas e liturgias, sempre carrega a marca das fragilidades e das virtudes humanas. ${ }^{246}$
\end{abstract}

O capítulo anterior, dedicado ao estudo de casos julgados pelos Tribunais pátrios, relativos à aplicação da Súmula 444 do Superior Tribunal de Justiça, e aos critérios utilizados pelos julgadores para se aferir o conceito de conduta social e personalidade, para fins de aplicação da reprimenda penal, confirmou algo que já se suspeitava quando do início do estudo.

A diversidade das decisões judiciais para casos similares, em termos objetivos, demonstrou algo de misterioso, que escapa ao entendimento racional. Transpondo, inclusive, a tradicional ideia de que o juiz, ao julgar, interpreta a lei a partir de um procedimento lógicodedutivo.

Destarte, a lei não se põe como um referencial seguro de uma aplicação uniforme do direito, sujeitas suas expressões a interpretações conflitantes, desfazendo-se a ingênua crença de que o juiz é a boca que diz a palavra da lei, na expressão de Montesquieu, nos restando ser apenas iluministas desiludidos, como refere Ferrajoli. ${ }^{247}$

O estudo dos julgados pátrios, no corte realizado, demonstrou a falácia do mito da neutralidade dos juízes, que como seres humanos, talhados por suas histórias de vida,

\footnotetext{
${ }^{246}$ Miguel Reale Junior. Razão e subjetividade no direito penal. Ciências Penais, São Paulo, ano 1, n. 00, 2004, p. 249.

${ }^{247}$ Miguel Reale Junior. Razão e subjetividade no direito penal. Ciências Penais, São Paulo, ano 1, n. 00, 2004, p. 229.
} 
contextos sociais e próprias idiossincrasias, não conseguem se desvencilhar de seus próprios preconceitos, no sentido de concepções antecipadas, para julgar. ${ }^{248}$

A tese irracionalista central sustenta que a tomada de decisão judicial não seria um procedimento racional, senão irracionalmente conduzido. Pois seria fruto de fatores psíquicos e sociais. E qualquer juiz vivencia esse processo e sabe que decidirá impulsionado por sua história pessoal, suas angústias e sonhos, sua fé ou seu agnosticismo, suas predileções, antipatias e idiossincrasias. ${ }^{249}$

\title{
Demonstrou-se que "o exercício da jurisdição acaba se pautando também por aspectos
} metajurídicos, de natureza psicológica, incidentes no curso da atuação de cada julgador - e tão alheios à sua vontade quanto mais inconsciente ele estiver deles". 250

\begin{abstract}
A ideia que vai permear a discussão é a da falibilidade de modelo de julgador (enquanto fruto decorrente de todo um universo epistemológico e de um ideal imagético de "operador jurídico" que a esse universo é correlato), caracterizado como eminentemente (meramente) técnico-legalista, e desconectado (conceitualmente) de possibilidades de que interferências subjetivas (psíquicas, emotivas, ideológicas) ajam em sua operação processual-decisória (tida, equivocadamente, como eminentemente lógica e racional). ${ }^{251}$
\end{abstract}

As decisões proferidas, nos casos apontados no Capítulo anterior, dizem muito da irracionalidade que ainda permeia as nossas Cortes, em seus julgamentos, demonstrando que mais que a interpretação da lei ao caso concreto, as decisões são influenciadas pelo subjetivismo de seus julgadores ${ }^{252}$, que por razões inconfessáveis, e, muitas vezes, até

248 "O paradigma cartesiano terminou por fazer dos conceitos de investigação científica e neutralidade racionalista um verdadeiro amálgama, e até hoje a imagem de perseguição causal é o que basta para legitimar os saberes obtidos, sem considerar que a pessoa do investigador não é elemento que possa ser desconsiderado, e que o agir técnico jamais será imune à pessoalidade (lato sensu) de quem o conduz." (Gabriel Antinolfi Divan. Decisão Judicial nos Crimes Sexuais: o julgador e o réu interno. Porto Alegre: Livraria do Advogado Editora, 2010, p. 41).

${ }^{249}$ José Renato Nalini. Perspectivas da Justiça e do Juiz no limiar do Século XXI. Tese de doutoramento apresentada à Universidade de São Paulo, em 2000, p. 89.

${ }^{250}$ Antoin Abou Khalil. A personalidade do juiz e a condução do processo. São Paulo: Antoin Abou Khalil, 2011, p. 124.

${ }^{251}$ Gabriel Antinolfi Divan. Decisão Judicial nos Crimes Sexuais: o julgador e o réu interno. Porto Alegre: Livraria do Advogado Editora, 2010, p. 16.

252 "Mas, na escolha de uma versão dos fatos, desde a direção da produção da prova até a valoração desta prova na seleção do que é relevante e, em especial, o que no evento é juridicamente relevante, o juiz decide de acordo com sua impressão, sua subjetividade, formada por suas circunstâncias de vida conformadoras de sua maneira de apreender e de avaliar os fatos." (Miguel Reale Junior. Razão e subjetividade no direito penal. Ciências Penais, São Paulo, ano 1, n. 00, 2004, p. 232). 
desconhecidas dos próprios, escondem na argumentação jurídica as verdadeiras razões da decisão.

Essa breve ponderação acima, antes do efetivo ingresso neste Capítulo, que tratará do Julgador, faz-se necessária, porque do resultado da análise da jurisprudência pátria, ficou clara a esquizofrenia do sistema, na aplicação da pena.

Antes de iniciar o estudo dos julgados, até por experiência profissional, em função de mais de 15 (quinze) anos de trabalho na área criminal, tínhamos ideia de que algo de enigmático acontecia no sistema judicial, mas não a real dimensão da extensão do problema.

Hoje, após a realização do estudo de casos julgados, temos que nosso sistema judicial encontra-se doente, precisando urgentemente de ajuda para resgatar a sua credibilidade, e para recuperar a saúde de seus principais prestadores de serviços, justamente, os julgadores. ${ }^{253}$

A análise dos julgados, com foco na descoberta daquilo que é tomado em conta pelos julgadores, como conduta social e personalidade, para proceder à fixação da pena-base além do mínimo legal, mostrou a irracionalidade do sistema, demonstrou que os julgamentos estão afastados do princípio da legalidade, na medida em que se atropelam critérios objetivos,

\footnotetext{
${ }^{253}$ Élio Braz Mendes, juiz titular da $2^{\text {a }}$ Vara da Infância e Juventude de Recife, em palestra intitulada "Aspectos psicopatológicos do ato de decidir", proferida na Escola Paulista da Magistratura, em 22.10.2012, trouxe um dado importante sobre a falta de saúde dos juízes brasileiros, que estão adoecendo, em função da pressão do ofício, da solidão da função, sendo que muitos estão se suicidando. Mencionou que atualmente se estuda um plano de suporte psicológico e emocional para os magistrados, denominado "Programa de Mentoria", que seria propiciado por juízes mais experientes, uma espécie de cuidador do ingressante e daqueles que estivem necessitando de ajuda para lidar com as diversas nuances da função. Seria um juiz mais experiente, que teria melhor desenvolvida a "escuta" para ouvir as angústias, as dúvidas e conflitos de seus colegas também julgadores, de forma a auxilialos a reencontrar o equilíbrio emocional. Em outra oportunidade, dessa vez como ouvinte, no II Seminário Ética para o juiz: um olhar externo, realizado em 22/11/2013, na Escola Paulista da Magistratura, Élio Braz Mendes levantou a questão do adoecimento psíquico, emocional e físico dos magistrados, que estão se utilizando de medicamentos e terapias seríssimas para manterem-se em seu papel, questionando o coordenador do evento, o Desembargador José Renato Nalini, na qualidade de Corregedor-geral da Justiça, acerca de quais medidas estariam sendo pensadas para preservar a saúde profissional dos juízes em São Paulo, ao que lhe foi respondido que nos dois anos de sua gestão na Corregedoria, seu gabinete funcionou como verdadeiro consultório psicológico, para ouvir as angústias dos magistrados, dizendo, ainda, que o pior era, muitas vezes, constatar que tais profissionais não se viam como enfermos, mas diziam-se vítimas do sistema de metas, do trabalho, e o quanto esta postura acaba atrapalhando a sua melhora. Citou trabalho iniciado por Ivan Sartori, para resgatar a autoestima dos funcionários, através de um programa de qualidade de vida, no qual se franqueava espaço para que os funcionários pudessem falar de seus problemas. Este espaço, permeado pela interdisciplinaridade, foi palco de eventos literários e etc. Disse, ainda, que mediante um trabalho informal, com magistrados que possuíam ferramentas fora do Direito, foi possível auxiliar muitos magistrados necessitados de aconselhamentos.
} 
conceitos típicos, julgando-se, segundo critérios completamente alijados da racionalidade, e conforme a subjetividade de cada julgador ${ }^{254}$.

Toda a exposição de Isay é dominada pela ideia de que "a intuição encontra sem procurar, a razão procura sem encontrar". Assim é que a decisão, a sentença se não deixa nunca compreender lógicamente: é no fundo "uma vivência" e, como tal, algo de irracional. Certo que se pretende por vezes verificá-la lógicamente pela sua referência à norma geral e abstracta. Mas nem por isso se pode pensar que a decisão deriva da lei, porque aquele controlo não é afinal vinculativo e o que em última análise decide é a intuição, a que se mistura o sentimento de justiça e utilidade. A experiência ensinaria - escreve Schwinge, resumindo o pensamento de Isay - que na prática a decisão só complementarmente "é racionalizada", isto é, fundamentada de acordo com os preceitos legais. Neste momento, porém, se o julgador verifica que a lei conduz a resultados diferentes daqueles a que irracionalmente chegou, afasta a disposição perturbadora por meio de "construção", quer dando à norma um sentido que exclui do seu âmbito o caso sub-judice - na interpretação da norma não haveria limites determináveis racionalmente (es gibt keine rationalbestimmte Grenze) -, quer arquitectando na situação de facto circunstâncias que tornem possível a aplicação de outro preceito. Pràticamente, a referência à lei seria, portanto, e só poderia ser uma ficção. ${ }^{255}$

${ }^{254}$ Karl Llewellyn, citado por Lídia Reis Almeida Prado, "acredita que, geralmente, a mente do juiz primeiro antecipa a decisão que considera justa (dentro da ordem jurídico-positiva) e depois procura a norma que pode servir de fundamento a essa solução, atribuindo aos fatos a qualificação apropriada. Percebe-se, por essa observação do autor, a admissão da existência, no processo decisório - sem excluir o prisma legal e o valorativo de aspectos extra-lógicos, relacionados com conteúdos subjetivos do juiz." (Lídia Reis de Almeida Prado. O juiz e a emoção: aspectos da lógica de decisão judicial. Campinas: Millenium Editora, 2003, p. 13). No mesmo sentido Jerome Frank, ao falar que: "The process of judging, so the psychologists tell us, seldom begins with a premise from which a conclusion is subsequently worked out. Judging begins rather the other way around-with a conclusion more or less vaguely formed; a man ordinarily starts with such a conclusion and afterwords tries to find premises which will substantiate it. Now, since the judge is a human being and since no human being in his normal thinking processes arrives at decisions (except in dealing with a limited number of simple situations) by the route of any such syllogistic reasoning, it is fair to assume that the judge, merely by putting on the judicial ermine, will not acquire so artificial a method of reasoning. Judicial judgments, like other judgments, doubtless, in most cases, are worked out backward from conclusions tentatively formulated. (Law \& the Modern Mind. Transaction Publishers. New Brunswick (USA) and London (UK), p. 108-109). Tradução livre: O processo de julgamento, de modo que os psicólogos nos dizem, raramente começa com a premissa de que uma conclusão seja posteriormente trabalhada. O julgamento começa sim ao contrário, com uma conclusão mais ou menos vagamente formada, um homem geralmente começa com tal conclusão e posteriormente tenta encontrar instalações que irá fundamentá-la. Agora, uma vez que o juiz é um ser humano e uma vez que nenhum ser humano em seus processos de pensamento normais chega a decisões (exceto em lidar com um número limitado de situações simples) por via de qualquer raciocínio silogístico tal, é justo supor que o juiz, apenas por colocar o arminho judicial, não vai adquirir um método tão artificial de raciocínio. Decisões judiciais, como outros julgamentos, sem dúvida, na maioria dos casos, são trabalhados para trás das conclusões provisoriamente formuladas

${ }^{255}$ Eduardo Henriques da Silva Correia. A teoria do Concurso em Direito Criminal: I - Unidade e Pluralidade de Infrações: II - Caso Julgado e Poderes de Cognição do Juiz. Almedina: Coimbra, 1983, p. 53. 
Compartilhando desse entendimento, Miguel Reale Junior dispõe que "Por outro lado, a conclusão a que chega o julgador deriva muitas vezes da sua sensação do certo e do errado, um sexto sentido ou intuição condiciona a valoração do fato, uma capacidade de intelecção a priori. Mas, ao contrário do que pondera Alexy no sentido de que deixa de haver lugar para a argumentação, na verdade há uma argumentação, mas que tem como ponto de partida a conclusão que se busca, a posteriori, fundamentar, em uma análise retrospectiva." ${ }^{256}$

Neil MacCornick, na mesma linha, dispõe que:

\begin{abstract}
Em todos os momentos de um processo semelhante, a falta de sinceridade é uma possibilidade evidente: um advogado experiente pode conseguir convencer um juiz de que uma reivindicação que ele próprio não considera válida está justificada nos termos da lei. Um juiz pode (como ficamos sabendo com bastante frequência) dar uma sentença favorável a uma querelante com um rostinho bonito ou proveniente de determinada classe social, na realidade porque gosta do rosto ou da classe (ainda de modo mais insidioso, por um preconceito inconsciente favorável ao rosto ou à classe), mas ostensivamente pelas razões que apresentar para sua decisão etc. e tal [...] (segue-se a um encadeamento cuidadosamente elaborado e ostensivamente impecável de razões de cunho legal para sua decisão). Assim pode acontecer; assim, às vezes, quase com certeza deve acontecer. ${ }^{257}$
\end{abstract}

E este fato não podia mesmo surpreender, haja vista que os julgamentos são prolatados por seres humanos, e como tais inseparáveis de seus mais obscuros sentimentos e básicos instintos, como bem aponta Gabriel Antinolfi Divan, quando diz que "Não existe possibilidade de conhecimento que não se mostre, em última análise, particular, perspectivo: o filtro pelo qual sofrem clivagem os conhecimentos adquiridos, processados e transmitidos pelo ser humano não pertence unicamente à esfera dos limites da Razão. É um filtro múltiplo, corpóreo

\footnotetext{
${ }^{256}$ Miguel Reale Junior. Razão e subjetividade no direito penal. Ciências Penais, São Paulo, ano 1, n. 00, 2004, p. 238. No mesmo sentido, Mariângela Gama de Magalhães Gomes, parafraseando Miguel Reale Junior consigna que "é possível sustentar, inclusive, que as decisões não decorrem de um processo racional de formação da convicção, mas defluem de posições subjetivas, fruto da experiência individual do julgador e de seus preconceitos de ordem política, econômica, social. Diz-se, aliás, que as decisões derivam dos impulsos do juiz, e as sentenças são fundamentadas de forma retrospectiva, a partir das intuições fruto do subjetivismo do julgador". (Mariângela Gama de Magalhães Gomes. Direito Penal e Interpretação Jurisprudencial: do princípio da legalidade às súmulas vinculantes. São Paulo: Atlas, 2008, p. 36).

${ }^{257}$ Neil MacCormick. Argumentação jurídica e teoria do direito. Tradução de Waldéa Barcellos. São Paulo: Martins Fontes, 2006, p. 18-19.
} 
- inclusive - que permite voz mesmo aos mais obscuros sentimentos e aos mais básicos instintos." 258

Temos que a possibilidade de cura do Judiciário terá como passo inicial a necessidade de assumir o lado humano da Justiça, partindo-se do pressuposto que o julgador é um ser humano, igual a todos os homens, que julga com suas emoções e paixões. E o desafio da magistratura será traçar-lhe um novo perfil, no qual a tarefa do magistrado, longe de se resumir ao exercício da subsunção do fato à norma, será capacitar-se, tanto para fora, mediante conhecimentos interdisciplinares ${ }^{259}$, como voltar-se para dentro ${ }^{260}$, através de um processo de autoconhecimento $^{261}$, tudo com o fim de bem compreender seus semelhantes.

Lídia Reis de Almeida Prado, citando entendimento de Jerome Frank, diz que "O aspecto importante na sentença, embora não o único, é a personalidade do juiz, sobre a qual

${ }^{258}$ Gabriel Antinolfi Divan. Decisão Judicial nos Crimes Sexuais: o julgador e o réu interno. Porto Alegre: Livraria do Advogado Editora, 2010, p. 52.

259 "Assumir o lado humano da justiça implicará falar tanto das paixões como da razão, tanto das emoções como da argumentação, tanto dos media como dos trâmites legais, tanto da prisão como das liberdades. Diante dessa constatação é que se mostra relevante a atuação do magistrado como agente de transformação social. Isto é, de incentivador e promotor de novos paradigmas que levam a sociedade a pensar em sua totalidade. Trata-se do juiz que estimula o diálogo, a humanidade, a fraternidade, a compaixão do eu em relação ao outro para que este se sinta valorizado frente àquele, porque o eu não é ninguém menos que o outro. Nesse sentido, pode o magistrado atuar de modo a provocar nos cidadãos o interesse pela discussão, pela participação e envolvimento na (re)construção de um consenso mínimo entre culturas e ideologias distintas. Neste contexto, o desafio atual de um novo perfil da magistratura não é mais um simples exercício da subsunção do fato à norma (aplicação do direito ao fato concreto), mas sim uma intensa atividade de construção e ponderação, participativa e dialética, que considera os imprescindíveis aportes transdiciplinares e que projeta cautelosamente os efeitos e as consequências da decisão para o futuro. Daí a importância da contínua capacitação do magistrado ao longo da carreira. Não apenas da capacitação jurídica, mas também da capacitação interdisciplinar. É neste ponto que se mostra relevante a universalização do conhecimento nas escolas da magistratura, assim como o intercâmbio dessas outras instituições das mais variadas áreas do saber. Capacitar o magistrado dos novos tempos não é torná-lo perito judicial, mas sim construir um novo perfil de magistrado que se preocupa com a totalidade para agir pontualmente."(Wellington Magalhães. Por uma revolução democrática da magistratura. Disponível em: <http://blogdofred.blogfolha.uol.com.br/2013/09/10/capacitar-o-magistrado-dos-novos-tempos/>. Acesso em: 10 set. 2013.

260 "Como assinala Zaccaria, exigir-se-ia do intérprete para escapar deste subjetivismo que se realizasse um processo de desfazimento ou desligamento dos preconceitos e de posturas pessoais, em uma reflexão autocrítica sobre-humana, que impõe um esforço infindável de abstração de seus próprios modos de ver e sentir a vida." (Miguel Reale Junior. Razão e subjetividade no direito penal. Ciências Penais, São Paulo, ano 1, n. 00, 2004, p. 239)

261 "Bastaria ao juiz, a cada dia, lembrar-se da limitação e da falibilidade humana, de que as criaturas não podem escapar. É preciso que o homem se governe; e, nada obstante, é ele um ser limitado; está sujeito à ignorância e ao erro, como todas as inteligências finitas; os débeis conhecimentos que tem os perde ainda; como criatura sensivel resulta sujeito a mil paixões". Essencial, portanto, que o homem se conheça cada vez mais a si mesmo, em suas fraquezas e deficiências, com isso aprendendo a melhor conhecer e a mais adequadamente julgar seu semelhante." (José Renato Nalini. Perspectivas da Justiça e do Juiz no limiar do Século XXI. Tese de doutoramento apresentada à Universidade de São Paulo, em 2000, p. 73). 
influem a educação geral, a educação jurídica, os valores, os vínculos familiares e pessoais, a posição econômica e política, os traços intelectuais e temperamentais. Pode controlar as indevidas influências desses fatores, se forem inconscientes, a boa disposição que os juízes tiverem para se auto-analisarem, adquirindo consciência de cada um deles."262

No mesmo sentido manifesta-se José Renato Nalini, para quem a disposição dos juízes para se autoconhecerem, é essencial ao juiz moderno, nos seguintes termos: "Em síntese, já não satisfaz o apego à racionalidade formal, nem se haverá de somente julgar sob o impulso das sensações. Impõe-se reconhecer a influência dos fatores desvinculados da razão no processo de formação da vontade judicial. Para isso, aprender a dominá-los, exercer o autoconhecimento e administrar suas deficiências mostra-se essencial ao juiz moderno."263

Compartilhando do entendimento acima esposado, Nereu José Giacomolli e Liza Bastos Duarte dispõem que:

É um tributo do ser-no-mundo o entendimento de si mesmo. O entendimento de si na interação com o mundo existencial que o habita e lhe atribui sentido, sendo que o sentido conferido às coisas é uma projeção desse seu mundo interior. Esse entendimento é necessário e instrumentaliza o juiz no ato de julgar. Dessa forma, o juiz nunca decide de forma neutra. Será sempre sujeito da tradição, que lhe servirá de sustentáculo no ato de julgar, nunca parando de repor-se, e de superar-se, pois a sua realidade, como a de outros seres, é a transposição de sentido projetada pelo ser, contextualizado na sua percepção da existência e existindo nela. ${ }^{264}$

Partindo, então, da premissa de que não há como afastar o subjetivismo das decisões judiciais, bem refletido no Capítulo anterior, no qual se ponderou diversas interpretações até de questões objetivas, justamente porque proferidas por seres humanos ${ }^{265}$. E partindo também da impossibilidade de se negar a força que tal subjetivismo exerce nos julgamentos,

\footnotetext{
${ }^{262}$ Lídia de Almeida Prado. O Juiz e a Emoção: aspectos da lógica de decisão judicial. Campinas: Millennium Editora, 2003, p. 18.

${ }^{263}$ José Renato Nalini. Perspectivas da Justiça e do Juiz no limiar do Século XXI. Tese de doutoramento apresentada à Universidade de São Paulo, em 2000, p. 93.

${ }^{264}$ Nereu José Giacomolli e Liza Bastos Duarte. "O mito da neutralidade na motivação das decisões judiciais: aspectos epistemológicos". Revista da Ajuris, Porto Alegre, Ajuris, ano XXXIII, n. 102, 2006, p. 292.

265 "O problema central do processo, como já advertiu Carnelutti é, antes de tudo, encontrar um homem digno de julgar. Pois, ainda na lição do grande mestre, "se removido o véu que encobre a res judicanda descobre-se outro homem. Assim, o desnível, que existia entre o homem que julga e a coisa a ser julgada, desaparece.". Com isto, quis ele dizer: no fundo o juiz, que é um homem, está sempre a julgar outro homem, ou seja, semelhante seu. Por isto, deve ter sempre presente que há de se defender, não apenas do mundo, mas, especialmente, defender-se de si próprio." (Pedro Máximo Paim Falcão. A Ética do Magistrado. In: José Renato Nalini (Coord.). Uma Nova Ética para o Juiz. São Paulo: RT, 1994, p. 148).
} 
sobrepondo-se a qualquer controle da razão ${ }^{266}$, pretende-se neste Capítulo abordar os juízes, estes seres que, subjulgados pela emoção, são, dentre outras responsabilidades, os incumbidos pela aferição da conduta social e personalidade, circunstâncias previstas no artigo 59 do Código Penal, paradigma para a aplicação da pena, quando da fixação da pena-base, bem como no momento de determinar-se o regime de cumprimento da pena.

Pretende-se, portanto, nesta oportunidade, tratar da figura crucial no processo de fixação da pena - o julgador - enfocando, no entanto, inicialmente, o seu universo interior.

Pouco se fala sobre a figura do juiz, sob esta perspectiva. A bem da verdade, já no próprio processo de seleção deste profissional, não há qualquer preocupação em conhecer a personalidade do juiz, seus temores e angústias, seus traumas, seus preconceitos, seus anseios, aspirações, sonhos e ilusões. ${ }^{267}$ Retroagindo um pouco mais, tem-se que o descaso a estes questionamentos inicia-se, ainda, na infância, como mais abaixo será salientado.

Se os concursos se preocupassem mais com o ser humano interessado em ingressar na Magistratura e menos com a sua possibilidade de decorar informações, teria início a verdadeira Reforma do Judiciário. [...] Para julgar um ser humano, o juiz precisa ser cada vez mais humano. O excesso de técnica pode ajudar a distanciá-lo desse ideal. É uma armadura a mais para afastá-lo do drama de que o processo está impregnado. A aprovação em concurso público para o qual acorrem milhares e no qual algumas dezenas logram sucesso, acarreta nítida dose de imodéstia. Da presunção à arrogância, é curta a distância. ${ }^{268}$

É parca a produção doutrinária sobre tema de importância ímpar, cujo objeto de estudo são as pessoas que têm por ofício julgar outras pessoas.

É praticamente inexistente o estudo sobre a psicologia do juiz ou sobre os fatores psicológicos conscientes e inconscientes presentes no ato de julgar. ${ }^{269}$

\footnotetext{
266 "Pouco importa, portanto, que se reconheça o valor da necessidade de se utilizar, no momento da decisão judicial, "conhecimentos extrajurídicos" para a resolução processual, uma vez que, por trás de uma indolente e reles simpatia para com os mesmos, há também a falta de noção quanto às possibilidades parcas de controle e regulação racional da subjetividade relativa aos próprios: a Razão pensa ter tudo sob seu controle, inclusive a dosagem de elementos "irracionais" de que pode "por vezes" se valer." (Gabriel Antinolfi Divan. Decisão Judicial nos Crimes Sexuais: o julgador e o réu interno. Porto Alegre: Livraria do Advogado Editora, 2010, p. 75) ${ }^{267}$ Prefácio de José Renato Nalini in Lídia Reis de Almeida Prado. O Juiz e a Emoção: aspectos da lógica da decisão judicial. Campinas: Millennium Editora, 2003, p. X.

${ }^{268}$ Prefácio de José Renato Nalini in Lídia Reis de Almeida Prado. O Juiz e a Emoção: aspectos da lógica da decisão judicial. Campinas: Millennium Editora, 2003, p. XI.

${ }^{269}$ Prefácio de Denise Gimenez Ramos in Lídia Reis de Almeida Prado. O Juiz e a Emoção: aspectos da lógica da decisão judicial. Campinas: Millennium Editora, 2003, de Lídia Reis de Almeida Prado, p. XIX.
} 
No ponto, é relevante mencionar a obra Juiz e Emoção: aspectos da lógica da decisão judicial, de Lídia Reis de Almeida Prado, que, em função de sua dúplice formação, em direito e psicologia, conseguiu com maestria demonstrar que o ato de julgar está no inconsciente coletivo e que, como todo arquétipo, o juiz também possui sua polaridade.

Tal obra tem especial importância, na medida em que desconstrói a crença, tão arraigada, de que o ato de julgar é absolutamente racional, sem se abalar pela existência de fatores psicológicos conscientes e inconscientes do julgador.

Ela trás de forma bem clara os aspectos internos que envolvem a atividade de julgar, sendo obra de referência obrigatória neste trabalho, cujo objeto tem, justamente, a ver com a previsão legal de o julgador analisar circunstâncias extremamente subjetivas de seus réus, o que abre uma porta muito larga para manifestação dos aspectos internos do julgador, que, com certeza, permearão o julgamento.

Dotado de uma postura interdisciplinar, o livro não se reduz à psicologia jurídica, dedicando-se, também, ao exame da influência, nas decisões judiciais, de fatores sociais, religiosos, econômicos e históricos.

Aliás, a valorização da interdisciplinaridade já não era sem tempo. É patente a necessidade de o universo jurídico aceitar o fato de que sofre influência de outros ramos do saber e que isso é positivo, pois aumenta a capacidade de compreensão do mundo.

Assim já manifestava, na década de 70, Rosa Maria Cardoso da Cunha, ao reconhecer que:

Finalmente, convém insistir em que todo conhecimento só pode ser depurado, desenvolvido e orientado para a objetivação, na medida em que é produzido com uma visão interdisciplinar. Por isso mesmo, o que reivindica para a construção de uma metodologia do ensino jurídico não é uma maniqueísta e castradora seleção de temas que rejeitem e excluem o conhecimento produzido em outras áreas. Também, na prática educacional, a utilização da teoria que esta disciplina conformará não afasta o recurso a outras teorias, que, compatibilizadas com a primeira, devem orientar os processos de ensino e aprendizagem. ${ }^{270}$

${ }^{270}$ Rosa Maria Cardoso da Cunha. Metodologia do Ensino Jurídico, Reflexões sobre a Necessidade de sua Sistematização. In: Luiz Alberto Warat e Rosa Maria Cardoso da Cunha. Ensino e Saber Jurídico. Rio de Janeiro: Eldorado Tijuca, 1977, p. 56-57. 
Não há mais espaço para ignorar que todos os ramos do saber se intercalam e que entendimentos estanques são maléficos, pois não contribuem com o entendimento do todo. A interdisciplinaridade expressa essa importância do conhecimento relacionado com a totalidade.

\begin{abstract}
Vista por essa perspectiva, a interdisciplinaridade enfatiza o homem enquanto ser social (que vive numa sociedade tecnologicamente desenvolvida), dotado de afetividade (que se relaciona com sua realidade interna) e com outros seres do meio em que vive. Possibilita, assim, a superação de um tipo de saber feito de especializações formais, o saber em migalhas, o saber sem sabor, que provoca a perda da visão da totalidade. Conforme a concepção sistêmica, até mesmo nas ciências da natureza (como nos mostram, por exemplo, as conquistas da Física moderna), inexiste distinção entre parte e todo, porque cada sistema é simultaneamente todo e parte, dependendo do ponto de referência. ${ }^{271}$
\end{abstract}

E é de posse desse conhecimento, sob, portanto, essa perspectiva, que se pretende desenvolver este capítulo, que tem como objeto principal a figura do julgador.

Antes de adentrar ao estudo da figura do julgador, propriamente dita, enfatizando-se a completa despreocupação com o "ser" de quem pretende ter como profissão o ato de julgar, é importante fazer pequenas digressões num tema, que também é de suma importância, e que tem relação com o objeto do trabalho.

Esse tema antecede a escolha de ser juiz, e trata do completo desrespeito com o "ser" e suas diversas manifestações, sejam elas quais forem, ainda, em infância.

Está-se a falar da educação, pautada na cultura da separação, que desconsidera as particularidades dos indivíduos, suas diferentes formas de aprendizagem, e promove o não desenvolvimento de potenciais, o tolhimento de escolhas, a rejeição de perfis não adequados, $o$ encaixotamento de talentos, a anulação das diferenças; em prol de um estandarte, de uma uniformização dos indivíduos, que buscam a felicidade fora.

Poder-se-ia perguntar qual a relação da educação com a aplicação da pena, precisamente na avaliação da conduta social e personalidade, que são os objetos de estudo deste trabalho.

Esclarece-se que o tema tem total conexão, uma vez que a criação desde a mais tenra idade é pela completa desconsideração das particularidades dos indivíduos; revelando-se

${ }^{271}$ Lídia Reis de Almeida Prado. O Juiz e a Emoção: aspectos da lógica da decisão judicial. Campinas: Millennium Editora, 2003, p.3. 
paradoxal a necessidade dessa avaliação, em sede de análise de conduta social e personalidade dos réus, por ocasião da fixação da pena-base, entre o mínimo e máximo.

A seguir, quer-se ponderar uma visão mais libertária da educação, que prime pela real preocupação com a essência do ser humano, suas buscas mais profundas, a reunião de suas partes separadas, para o encontro de sua integridade, e consequente realização do seu propósito de vida.

\title{
4.1 Uma educação com liberdade para alcançar a integração ${ }^{272}$
}

\begin{abstract}
A palavra educação - de ex (movimento para o exterior) e ducere (conduzir) remete a um processo que consiste em trazer à tona as possibilidades do indivíduo que se educa, o educando. Para a educação, o indivíduo aparece como um saber a ser desvendado, a ser desdobrado, como um centro irradiador de luz a ser descoberto. Já a palavra ensino - de in (movimento para o interior) e signo (símbolo, signo, inscrição) - remete a um processo que consiste em incutir no indivíduo que se ensina um conjunto de saberes anteriores e externos a ele. Para o ensino, o indivíduo aparece como ausência de saber, como vazio, como folha em branco a ser preenchida com a inscrição da cultura. A palavra aluno seria adequada aqui. Significaria, etimologicamente $-a$ (privado de) e lúmen (luz)-, um ser privado de luz, poço vazio e escuro, que cabe aos educadores preencher com o lume de seu saber. Vaidosa de seus dons iluminadores, a educação, entendida como ensino, pode produzir efeitos nefastos. Ao tomar o indivíduo como objeto, agindo irrestritamente sobre ele como um sujeito despótico, ela anula a possibilidade de irrupção da diferença, uniformiza e massifica. Mas, se se põe na perspectiva de seu sentido original, entendendo-se como processo de condução dos indivíduos para fora de si mesmos, para fora dos espaços convencionais da ordem simbólica, na direção de uma ordenação nova da realidade, aí, sim, a educação pode cumprir o papel de redentora das possibilidades de uma humanidade cada vez melhor. ${ }^{273}$
\end{abstract}

O tema educação, além da conexão já estabelecida acima, tem especial importância quando se fala do julgador, uma vez que demonstra que a falta de interesse na perquirição da interioridade dos que pretendem julgar não se restringe somente aos concursos para ingresso na carreira, tendo, ao contrário, origem muito mais remota.

\footnotetext{
${ }^{272}$ Esta ideia foi, inicialmente, desenvolvida por mim, em trabalho de conclusão de curso, em disciplina de Filosofia de Direito, denominada "A Filosofia em Questão". No entanto, para fins deste novo trabalho, muita alteração foi efetuada, a partir de inclusões de conceitos desconhecidos na ocasião da entrega de referido trabalho.

${ }^{273}$ John Holt. Como as Crianças Aprendem. Tradução de Walther Castelli Jr.. $2^{\mathrm{a}}$ edição. Campinas, SP: Verus Editora, 2010, p. 8- 9.
} 
O desrespeito e a falta de preocupação na persecução de suas dúvidas, desejos, indagações, angústias, infelicidades, sentimentos de "inadequação" ao sistema que lhes é proposto remonta aos bancos escolares, ao período de formação da personalidade, nos quais é imprescindível que se enxergue o ser de luz que existe em toda criança. ${ }^{274}$

Tal desrespeito, aliás, data de mais longe, tendo origem com nascimento da criança. Não é possível avançar neste tema, nesta oportunidade, até porque a sua importância demandaria uma nova dissertação.

No entanto, é importante ponderar que já no nascimento, não há qualquer preocupação com os desejos das crianças, na medida em que, apenas para citar um exemplo, não se respeita a necessidade do bebê mamar na hora que quiser, ditando-se regras para horários de mamadas, sonecas e tudo o mais; justificando-se na crença de que o bebê ficará mal acostumado, dentre outras.

O leite flui quando a presença constante do bebê gera na mãe a energia vital, a magia indescritível que só o contato e a proximidade amorosa podem produzir. Por outro lado, os horários, os pré-conceitos, a separação do corpo do bebê e a preocupação em não deixá-lo mal-acostumado conseguem "cortar" o leite. ${ }^{275}$

Os pediatras costumam recomendar que se acorde o bebê a cada três horas. O que acontece nestes casos é que, se o bebê estiver dormindo profundamente, mal sugará o peito e voltará a dormir. Então, os pediatras recomendam a mamadeira, uma vez que o bebê, mesmo adormecido, ingere seu conteúdo com uma atitude passiva. ${ }^{276}$

O que me parece espantoso é a facilidade com que as mães acreditam no pediatra que lhes entrega uma receita com o cardápio diário. Completamente dissociadas de sua intuição e de sua relação íntima com os códigos específicos que conseguiram estabelecer com a criança, caem em um abismo escuro, julgando-se incapazes de decidir e negando o vínculo poderoso que as une a seus filhos por causa de um papel assinado, carimbado e abençoado pelo manto do 'suposto saber'. ${ }^{277}$

\footnotetext{
274 "Quando eu era adulto, quanto mais uma coisa me interessava, melhor eu era capaz falar a respeito. Mas com as crianças talvez seja diferente. Quando um assunto nos importa muito, torna-se difícil falar sobre ele, mesmo quando sabemos a matéria. Como se tivéssemos vergonha, medo de dizer algo que não se deve dizer. Porque tem uma coisa chata na escola: a gente tem de falar cientificamente, para ganhar uma boa nota, um elogio, ou mesmo uma reprimenda, mas nunca do jeito como a gente sente." (Janusz Korczak. Quando eu voltar a ser criança. Tradução de Yan Michalski. São Paulo: Summus, 1981, p. 40).

${ }^{275}$ Laura Gutman. A maternidade: e o encontro com a própria sombra. Tradução de Luís Carlos Cabral. $2^{\mathrm{a}}$ ed. Rio de Janeiro: BestSeller, 2012, p. 74.

${ }^{276}$ Laura Gutman. A maternidade: e o encontro com a própria sombra. Tradução de Luís Carlos Cabral. $2^{\mathrm{a}}$ ed. Rio de Janeiro: BestSeller, 2012, p. 75.

${ }^{277}$ Laura Gutman. A maternidade: e o encontro com a própria sombra. Tradução de Luís Carlos Cabral. $2^{\mathrm{a}}$ ed. Rio de Janeiro: BestSeller, 2012, p. 79-80.
} 
Laura Gutman, autora de A maternidade e o encontro com a própria sombra ${ }^{278}$, questiona a influência da posição dos “opinólogos" de plantão, do impacto da cultura, no momento do parto, no nascimento dos bebês, colocando a sua versão do quanto pode ser maléfico para a criança a existência de tantas regras a serem seguidas, com o afastamento da intuição das mães da relação.

Ela diz que cada díade mãe-bebê é única, e nenhuma outra experiência pode servir de referência a seguir, pois no relacionamento mãe e filho, vários fatores são envolvidos, seja no plano material, seja em planos mais sutis, como o espiritual.

Cada mãe, quando lhe é permitido, consegue reconhecer suas necessidades e as de seu filho e qual a situação que os torna mais harmônicos e felizes. Ninguém fora da relação tem o direito de dar sugestões genéricas sobre como e quando se deve desmamar um bebê, se ainda não foi formulado um pedido de ajuda concreto nesse sentido. [...] Deveríamos refletir sobre o que estamos permitindo que ocorra em nossa sociedade. Por que qualquer um pode palpitar sobre uma coisa tão íntima como é o início ou o fim da lactação e por que as mulheres admitem expor sua maior fragilidade e levar em conta qualquer lobo que se disfarça de vovozinha para comêlas? Por que insistimos em nos aferrar à menina que vive dentro de nós, e não permitimos o desenvolvimento de nossa consciência? Qual é o risco de reconhecer nossas certezas mais íntimas e lhes dar credibilidade? ${ }^{279}$

O tema da amamentação, definitivamente, não é objeto deste trabalho, no entanto, os trechos acima foram colocados, apenas para demonstrar como, desde muito cedo, as pessoas deixam de escutar a voz de seus corações, em prol de conhecimento emprestado. Renegam sua intuição, e se submetem ao que culturalmente é aceito, e com isso dão início ao processo de separação, onde a criança já sente a primeira rejeição, a primeira frustração, com o afastamento de sua mãe.

Não existe um atuar correto. Ninguém pode atestar que uma criança criada no colo vai ficar mal-acostumada se comparada àquela que cresceu no berço, chiqueiro, ou carrinho. Não há regras nem exceções.

\footnotetext{
${ }^{278}$ Laura Gutman. A maternidade: e o encontro com a própria sombra. Tradutor: Luís Carlos Cabral. $2^{\mathrm{a}}$ ed. Rio de Janeiro: BestSeller, 2012.

${ }^{279}$ Laura Gutman. A maternidade: e o encontro com a própria sombra. Tradução de Luís Carlos Cabral. $2^{\mathrm{a}}$ ed. Rio de Janeiro: BestSeller, 2012, p. 81-82.
} 
Milhares são os livros que tratam de técnicas para criação e educação de crianças. São regras e horários para mamadas, fraldas, sonecas, banhos. Até sobre interpretação de choro já escreveram.

Desde cedo, busca-se fora a noção de normalidade, de adequação àquilo que é socialmente correto. E na medida em que se busca o referencial fora, as crianças ficam reféns desta criação imatura, que se submete ao conhecimento exportado e que, por falta de confiança, tira de seus filhos a possibilidade de emergir a originalidade que todo ser humano tem.

É nesse sentido que se entende que as crianças já, desde recém-nascidas, são tolhidas de suas vontades originais, pois todo e qualquer ato seu é interpretado, em função de um conhecimento externo, de certo ou errado, adequado ou inadequado, e assim por diante, como se entre seres humanos, fosse possível essa qualificação reta e precisa.

Há um filme indiano chamado "Taare Zameen Par - Every Child is Special"280, cujo significado é "Estrelas na Terra - Toda criança é especial", que traz uma mensagem para o mundo sobre o verdadeiro papel de um educador na formação de um novo ser humano.

Ao afirmar no título que toda e qualquer criança é especial, que são como estrelas na Terra, a proposta é trazer a ideia de que não se pode negligenciar a diversidade e preciosidade dos projetos de gente de nosso mundo, pois são eles que fazem o futuro.

O filme vai muito além de tocar na sensibilidade de ser criança e educador; ele manda uma mensagem do papel de ser humano.

\footnotetext{
280 Taare Zameen Par - filme da produção de Bollywood, em 2007 - trata de uma criança que sofre com dislexia e custa a ser compreendida. Ishaan, de 9 anos, já repetiu uma vez o terceiro período (no sistema educacional indiano) e corre o risco de repetir de novo. Ele não consegue acompanhar as aulas, porque as letras embaralham e dançam em sua frente. Seu pai acredita que a criança é preguiçosa e não tem disciplina. Após ser chamado na escola para falar com a diretora, o pai do garoto decide levá-lo a um internato, sem que a mãe possa dar opinião alguma. Tal atitude só faz regredir em Ishaan a vontade de aprender e de ser uma criança. Ele entra em depressão, sentindo falta da mãe, do irmão mais velho, da vida. No internato, o tratamento é muito rude. Inesperadamente, um professor substituto de artes entra em cena e percebe que algo de diferente acontece com Ishaan. Chegando à conclusão de que a criança sofria de dislexia, ele traça um ambicioso plano para resgatar aquele garoto que havia perdido sua luz e vontade de viver.
} 
De fato, sem a preocupação com a formação das crianças, com olhar do coração, certamente não haverá futuro questionamento de qualquer aspecto interior de nenhum adulto. Então, até para que se questionem as opções dos adultos, como as dos juízes, que são o caso em questão, necessário buscar, ou melhor, resgatar a originalidade das crianças.

Tércio Sampaio Ferraz Junior ${ }^{281}$, citando Karl Jaspers, menciona que:

Num de seus livros, o de Introdução à filosofia, esse grande professor de medicina, psiquiatria, psicologia, que depois se tornou filósofo, Karl Jaspers, diz que as perguntas metafísicas são feitas pelos filósofos e pelas crianças. Essa frase sempre me impressionou. Pergunta de filosofia é pergunta infantil, só criança faz. Todos nós já lidamos com esse fenômeno, ou passamos por ele. Toda criança passa pela fase das perguntas, e as perguntas que fazem nessa idade (começam com dois anos e meio, três anos, até uns quatro anos) são muito curiosas; são essas as perguntas filosóficas. A criança chega para o pai, ou para a mãe e pergunta: "Por que o mar é salgado? O pai talvez responda: "Tem alguém lá no fundo fazendo sal, ou alguém lá no outro canto jogando sal...". Mas depois ela volta, com uma pergunta talvez mais complicada: "Mas por que o mar é mar?". Talvez a essa altura o pai diga: "Vai brincar com seu irmãozinho!

E continua, no mesmo artigo, dizendo que a pergunta da criança é uma pergunta atrevida, daquele que chega ao mundo, mas que ainda não foi subjulgado por ele, concluindo que o adulto, que, por sua vez, já se encontra subjulgado, se assusta com tal tipo de indagação.

\begin{abstract}
A pergunta infantil é uma pergunta atrevida. É a pergunta de quem chega ao mundo. É a pergunta de quem não foi subjulgado pelo mundo. Subjulgado pelo mundo no sentido de subjulgado pela língua que me permite lidar com o mundo. A criança ainda não sabe lidar, como o adulto lida, com essas expressões do porquê da nossa vida. O mar, o sal, o meu pai, a minha mãe são palavras com as quais nós adultos lidamos com a maior facilidade, que compõem o nosso mundo, um mundo que já está aí quando a gente chega, e que nos subjulga. Mas não quando somos crianças, no momento em que estamos entrando nesse mundo, razão pela qual nessa idade todo mundo faz esta pergunta esquisita: "O que é mar?". E quando não recebe a resposta evasiva, "vai brincar", recebe a resposta talvez mais confusa ainda, e que assusta quem responde e pensa sobre o que responde. "Ora, o mar é o mar!"é a resposta mais plausível de quem já está subjulgado.
\end{abstract}

É justamente sobre a natureza questionadora da criança, deste perguntador nato, deste filósofo original, que tem sede de explorar o mundo, de entender tudo à sua volta, e que ainda não foi subjulgado pelas regras de conveniência, pelo sistema, e por tudo o mais que o

\footnotetext{
${ }^{281}$ Ferraz Junior, Tércio Sampaio. Filosofia do Direito: do perguntador infantil ao neurótico filosofante. In: Alaor Alves et al. O que é a filosofia do direito? Barueri, SP: Manole, 2004, pg. 109-120.
} 
controla e engessa, e com o intuito de evitar que essa criança se transforme em adulto indiferente, alienado a seu chamado interno, que se pondera a criação de nossas crianças, no atual sistema educacional ${ }^{282}$ e por pais, que também se submeteram a ele.

\begin{abstract}
Uma das coisas que se descobrem ouvindo as conversas das crianças é que as questões que elas propõem a si mesmas são sempre grandes questões. Elas não perguntam: "Por que a água sai da torneira?"Preferem: "De onde veio o universo?"As crianças não são apenas filósofos. São cosmólogos, inventores de mitos e de religiões. São como hindus, que apareceram com a idéia de que havia uma tartaruga em cujo dorso o mundo foi criado ou a de que os deuses trouxeram o fogo aos homens. Nós tendemos a tratar com condescendência as histórias e fantasias infantis e a extrair delas uma visão ornamental. "É uma história muito bonita, querida, mas você sabe que não é verdadeira, não é?’Mas a criança que é capaz de tais histórias está envolvida num trabalho sério. Não está só se divertindo. Está tentando construir um modelo de universo de fato mais grandioso do que jamais pudemos imaginar - a não ser, talvez, em nossa infância. Ela está fazendo perguntas a si mesma sobre o tempo, a vida, Deus e a criação. Repito: está trabalhando como um filósofo. Deveríamos dar a ela tempo para pensar. ${ }^{283}$
\end{abstract}

O objetivo deste item, inserido no capítulo que trata do julgador, também é chamar atenção para o fato de que a educação, nos padrões atuais, é um sistema competitivo, regulador de comportamentos, destruidor de potenciais, em que, na maioria dos casos, as crianças são vistas como números, estatística, aptas a atingir ou não o resultado esperado, e que tal visão, a posteriori, criará um adulto que escolherá sua profissão, objetivando ter sucesso financeiro, status, reconhecimento, estabilidade e poder.

Ao compartilhar do entendimento acima, José Renato Nalini, criticando as escolas, especialmente as particulares, dispõe que "a escola particular, que poderia converter-se em gueto das elites culturais, não tem - como regra - se portado diversamente. É uma empresa - e muito lucrativa - e seu compromisso é com a preparação dos jovens para a estúpida maratona

\footnotetext{
${ }^{282}$ A Escola não faz pensar. Não ensina a raciocinar, a ter discernimento. Não se preocupa com valores que, segundo entende - até como auto-defesa - constituem obrigação do lar. Oferece informações e, ao final do contrato, entrega diplomas. Não favorece o vínculo da comunidade, da família e do próprio educando com a instituição." (José Renato Nalini. Formação do Juiz. In: José Renato Nalini (coord). Formação Jurídica. São Paulo: RT, 1994, p. 134-135).

${ }^{283}$ John Holt. Aprendendo o tempo todo: como as crianças aprendem sem ser ensinadas. Tradução de Walther Castelli Jr. Campinas, SP: Verus Editora, 2006, p. 176.
} 
competitiva dos vestibulares, formando profissionais que se envolvem no plano universitário apenas para responder a uma imposição da sociedade de consumo."284

Este padrão de ensino, que está muito distante daquilo que, de verdade, significa educação, gera crianças frustradas, reprimidas e tristes e, na sequência, adultos recalcados, que se movem no mundo, de forma programada, sem irreverência, espontaneidade, reféns dos vários papéis que lhe são esperados. São atores das expectativas alheias, e não de suas próprias histórias. São almas que vagam perdidas, cada vez mais afastadas da tão sonhada individuação.

Luis Alberto Warat diz que "Nascemos príncipes e a educação faz de nós sapos"285.

A busca da tão almejada individuação é algo inquietante, sendo certo que já há educadores que escreveram sobre o assunto há um longo tempo.

Para ilustrar a necessidade de se alterar, desde cedo, o paradigma daquilo que se espera das pessoas, já na mais tenra idade, é importante colacionar o pensamento de John Holt, americano, nascido em Nova York, em 1923, que já na década de 50, então como professor convencional de quinta série em uma escola particular americana, questionava-se sobre a razão de ele ensinar e de os alunos não aprenderem. Quando a partir de então, passou a refletir o que se passava com as crianças em suas tentativas de entender o mundo a sua volta. E em 1967, após escrever o seu segundo livro, criou um centro de estudos de aprendizagem infantil, o Holt Associates, lá trabalhando com crianças e pais em experiências que deram importante impulso ao movimento do homeschooling (escola em casa) ${ }^{286}$ nos Estados Unidos, e ao reconhecimento da legalidade dessa forma de educação.

\footnotetext{
${ }^{284}$ José Renato Nalini. Formação do Juiz. In: José Renato Nalini (coord.). Formação Jurídica. São Paulo: RT, 1994, p. 134.

${ }^{285}$ Luis Alberto Warat. Surfando na pororroca: ofício do mediador. Orides Mezzaroba et al. Florianópolis: Fundação Boiteaux, 2004, p. 17.

${ }^{286}$ Selection by http://www.holtgws.com (consulta em 14/07/2011) [...] I have used the words "homeschooling" to describe the process by which children grow and learn in the world without going, or going very much, to schools, because those words are familiar and quickly understood. What is most important and valuable about the home as a base for children's growth into the world is not that it is a better school than the schools but that it isn't a school at all. It is not an artificial place, set up to make "learning" happen and in which nothing except "learning" ever happens. It is a natural, organic, central, fundamental human institution, one might easily and rightly say the foundation of all other institutions. We can imagine and indeed we have had human societies without schools, without factories, without libraries, museums, hospitals, roads, legislatures, courts, or any of the institutions which seem so indispensable and permanent a part of modern life. We might someday even choose, or be obliged, to live once again without some or all of these. But we cannot even imagine a society without homes,
} 
O intuito de trazer o pensamento deste autor, bem como as suas observações quanto ao aprendizado das crianças, em ambientes livres de pressão e obrigação, é o de promover o questionamento da educação recebida pelas crianças nas escolas, e de, no mais profundo, questionar as expectativas da sociedade, que se preocupa muito mais com o atendimento às regras convencionais, que com o despertar da individualidade de cada qual.

Acredita-se, na esteira do proposto por John Holt, que aprender é uma característica inata do ser humano, e que esse conhecimento se estrutura e aperfeiçoa no seu devido tempo, incumbindo ao educador compartilhar as experiências e descobertas junto à criança, respeitando o seu currículo interno. Entende-se que um programa curricular imposto de fora para dentro rompe a fluência dos relacionamentos, criando uma rotina cristalizada que impermeabiliza as interações e impede a experiência viva de manifestações da criança.

Essa rotina cristalizada, que anula a fluência das relações, e impede as manifestações mais originais e puras das crianças, é o que anos mais tarde se verifica, de forma mais intensificada, quando, como no caso deste trabalho, nenhuma preocupação existe em se perquirir a vocação daqueles que escolheram julgar outras pessoas.

Propõe-se que se busque na área da educação um caminho, com a menor ingerência possível do adulto, pelo qual haja possibilidade de afirmar no ser humano a capacidade de aprendiz nato, disposto a aprender tudo que realmente tenha um significado real para o processo de construção de si mesmo, integrando de forma criativa no social. ${ }^{287}$

even if these should be no more than tents, or mud huts, or holes in the ground. What I am trying to say, in short, is that our chief educational problem is not to find a way to make homes more like schools. If anything, it is to make schools less like schools. Tradução livre: Eu usei a palavra educação em casa para descrever o processo pelo qual cada criança cresce e aprende no mundo sem ir, ou indo muito, a escolas, porque tais palavras são familiares e de rápido entendimento. O que é mais importante e valioso sobre o lar como base para o crescimento das crianças no mundo não é o fato de ser melhor escola que as escolas, mas sim o fato de não ser uma escola. Não é um lugar artificial, criado para fazer "aprender", no qual nada além de aprender acontece. É uma natural, orgânica, central, fundamental instituição humana, a fundação de todas as outras instituições. Nós podemos imaginar, e de fato, nós tivemos sociedades humanas sem escolas, sem fábricas, sem bibliotecas, museus, hospitais, avenidas, leis, tribunais, ou qualquer uma das instituições que parecem tão indispensáveis e permanentes da vida moderna. Nós podemos, um dia, até escolher, ou sermos obrigados, a viver, uma vez mais, sem parte ou todas ela. Mas nós não podemos sequer imaginar uma sociedade sem lares (casas), mesmo que eles sejam não mais que tendas, ou cabanas de barro, ou buracos no chão. O que estou tentando dizer é que nosso maior problema educacional não é encontrar uma forma de fazer os lares mais parecidos com as escolas, mas sim, fazer as escolas menos parecidas com escolas.

287 "Mais ainda, a experiência universal dos educadores genuínos prova que o sujeito ativo do processo educacional é o estudante, não o professor, o diretor da escola ou toda a burocracia estatal reunida. Ninguém 
A escolha de John Holt, em específico, ocorreu após menção de Ana Thomaz, em palestra sobre desescolarização de adultos escolarizados, em 11 de maio de $2011{ }^{288}$ cujo assunto era um convite para nos darmos conta de que a escolarização espartana nos tornou soldados de uma cultura, afastando-nos, assim, de nossa pulsão singular.

Uma vez que não nascem escolarizadas, as crianças ainda estão diretamente conectadas às suas pulsões, aos seus desejos e em busca do desenvolvimento de suas potencialidades, e através do contato com seus pais e educadores, escolarizados, submetem-se ao processo de desconexão e iniciam as buscas referenciais externas, distanciando-se cada vez mais de si mesmas.

Pelo dogma da escolarização, é muito complicado compreender e aceitar o processo natural de aprendizagem das crianças, sem fazer qualquer intervenção. Em algum momento, vai-se atuar, sempre com fundamento numa crença já cristalizada do valor positivo da escolarização. $^{289}$

pode "dar" educação a ninguém. Educação é uma conquista pessoal, e só se obtém quando o impulso para ela é sincero, vem do fundo da alma e não de uma obrigação imposta de fora. Ninguém se educa contra a sua própria vontade, no mínimo porque estudar requer concentração, e pressão de fora é o contrário da concentração. $\mathrm{O}$ máximo que um estudante pode receber de fora são os meios e a oportunidade de educar-se. Mas isso não servirá para nada se não estiver motivado a buscar conhecimento. Gritar no ouvido dele que a educação é um direito seu só o impele a cobrar tudo dos outros - do Estado, da sociedade - e nada de si mesmo." (Olavo de Carvalho. $O$ Mínimo que você precisa saber para não ser um idiota. $5^{a}$ ed. Rio de Janeiro: Record, 2013, p. 359).

288 Ana Thomaz - professora da Técnica Alexander, estudou 3 anos em Londres, quando começou a desconstrução de sua identidade. Na volta ao Brasil conheceu o filósofo Luiz Fuganti - Escola Nomade de Filosofia, a qual é hoje em dia aliada.

${ }^{289}$ É algo desconfortante observar as crianças sem fazer qualquer movimento de intromissão. É difícil abandonar o papel de constante "professor". E esta constatação também foi observada por Janus Korczak, que também foi professor, quando diz:"Parece-me que as crianças muitas vezes trabalham inspiradas, só que os outros atrapalham. Por exemplo: você está contando algo, ou lendo, ou escrevendo. O trabalho está indo bem. Ou você entendeu imediatamente a solução de um problema. Inclusive pode haver um erro qualquer, mas não chega a ser um erro, ou então só um errinho. Mas logo alguém interrompe, manda corrigir, repetir, acrescentar algo, ou faz questão de explicar alguma coisa. Está tudo perdido. Você se aborrece, perde a vontade, não consegue mais nada." (Janusz Korczak. Quando eu voltar a ser criança. Tradução de Yan Michalski. São Paulo: Summus, 1981, p. 35). 
Isso ocorre, porque, na verdade, acredita-se que as crianças são incapazes de aprender qualquer coisa sem que um adulto as ensine. ${ }^{290}$

As obras de John Holt, praticamente desconhecidas no Brasil, tratam das experiências vividas por ele, com crianças, e da observância do método natural de aprendizagem de todas elas. $\mathrm{Na}$ verdade, as obras falam do aprendizado sem qualquer professor, deixando a espontaneidade, a curiosidade das crianças falarem.

Podemos olhar, com grande proveito, para a atividade de ajudar as crianças a aprender e a explorar o mundo como um ramo das ciências naturais, parecido como o cultivo de plantas exóticas, ou a criação de animais pouco conhecidos, ou ainda a tentativa de estabelecer comunicação com golfinhos ou baleias. O que se requer para tais atividades são capacidades que muito poucos professores, diferentemente dos grandes naturalistas, têm. Uma é a capacidade de observar de modo concentrado e minucioso, com grande atenção para o detalhe. Outra é a capacidade de relatar, também detalhadamente, o que se viu. [...] Enquanto essa observação atenta e paciente é mais difícil para os professores, ela se manifesta mais facilmente nos pais por causa do amor - e por causa do interesse que dele decorre - pelos filhos. Como um naturalista, um pai observador estará sempre alerta tanto para os pequenos indícios quanto para os grandes padrões do comportamento das crianças. Notandoos, um pai pode frequentemente auxiliar com a oferta de sugestões e experiências, assim como pode decidir sobre a adequação do auxílio e das explicações que foram dadas às crianças. ${ }^{291}$

Alerta também para o grande risco de, desde cedo, os pais criarem os filhos como um objeto a ser programado, projetado para alcançar determinados objetivos, sem a preocupação com sua vontade original.

Os experimentadores, dissecadores e manipuladores conduzirão as crianças a comportamentos artificiais, a decepções, à evasão escolar e à retração, frustrada, em si mesmas. Fazer bem o trabalho não é tanto uma questão de técnica quanto uma questão de espírito. A diferença entre pais dedicados que sentem prazer em estar com os filhos, brincando de "Hoje é domingo, pede cachimbo" e fazendo cócegas em seus bebês sorridentes, e dois clínicos ansiosos, fazendo "estimulação tátil" nessas

\footnotetext{
290 "Sempre que, sem ser solicitados, sem ser convidados, tentamos ensinar algo a alguém, transmitimos a essa pessoa uma mensagem de duplo sentido. A primeira parte da mensagem é: estou lhe ensinando algo importante, mas você não é inteligente o suficiente para perceber isso. A menos que eu ensine isso a você, você muito provavelmente nunca descobrirá sozinho. A segunda parte da mensagem é: o que estou lhe ensinando é tão difícil que, se eu não lhe ensinar, você nunca aprenderá." (John Holt. Aprendendo o tempo todo: como as crianças aprendem sem ser ensinadas. Tradução de Walther Castelli Jr. Campinas, SP: Verus Editora, 2006, p. 148)

291 John Holt. Aprendendo o tempo todo: como as crianças aprendem sem ser ensinadas. Tradutor: Walther Castelli Jr. Campinas, SP: Verus Editora, 2006, p. 152
} 
mesmas crianças, para que elas um dia se tornem mais espertas que as outras e entrem na universidade, pode não ser na aparência uma grande diferença. Mas, na verdade, é a diferença entre a noite e o dia. Entre as duas maneiras de olhar para as crianças que estão se tornando cada vez mais freqüentes nos dias de hoje - como monstrinhos malévolos que precisam ser tratados à base de castigos, ou como pequenos computadores de duas pernas, que podemos programar para que se tornem gênios-, é difícil saber qual a pior, qual a que fará mais estragos. Escrevi este livro para me opor a ambas. ${ }^{292}$

É interessante mencionar que John Holt, em virtude dos anos que observou as crianças em ambientes escolares e fora deles, pôde constatar o quanto, já desde pequenas, as crianças tentam agradar os adultos, se adequando às determinações externas. No entanto, o resultado é funesto, nos termos de suas próprias palavras:

\begin{abstract}
Quais são os resultados? Somente poucas crianças se tornam boas em aprender no ambiente escolar, exatamente por conta da forma como queremos que aprendam. A maioria sente-se humilhada, amedrontada e desencorajada. Elas usam a mente não para aprender, mas para livrar-se das coisas que lhes recomendamos que façam a fim de aprender. No curto prazo, essa estratégia parece funcionar. Permite a elas que passem pela escola, que agüentem o período que ali permanecem, ainda que aprendam muito pouco. Mas, no longo prazo, essas manobras cansam, castram a inteligência e frustram o natural desejo de aprender. Terminam por destruir o caráter e a inteligência. Esse tipo de atitude, tornando-se sistemático, impede que as crianças desenvolvam plenamente suas potencialidades e as condena à condição de seres humanos mais limitados do que poderiam ser. Esse é o verdadeiro fracasso que acontece na escola; dificilmente alguém escapa. ${ }^{293}$
\end{abstract}

John Holt entende que é justamente antes do efetivo ingresso na escola que as crianças mais aprendem, pois estão livres, sem qualquer pressão, estimuladas apenas pelo natural desejo de conhecimento do mundo à sua volta.

\footnotetext{
${ }^{292}$ John Holt. Como as Crianças Aprendem. Tradução de Walther Castelli Jr. $2^{\mathrm{a}}$ ed. Campinas, SP: Verus Editora, 2010, p. 39. Na mesma obra, na página 73, John Holt fala da importância do encantamento com o trato com as crianças, ressaltando que os melhores jogos com crianças fluem fácil e naturalmente de uma situação momentânea, não se conseguindo bons jogos ou brincadeiras planejando-se com antecedência, e que o aceite de brincar com elas apenas por diversão é que faz toda a diferença: "O espírito desses jogos é tudo. O único bom motivo para fazê-los com bebês é nosso amor por estes, é o fato de sentirmos prazer em jogar com eles e em compartilhar o encantamento que experimentam ao jogar - e não porque queremos que algum dia eles entrem na universidade. É nosso encantamento com as crianças e com as brincadeiras que pode tornar essas atividades divertidas e úteis para os bebês. Se retirarmos o encantamento e colocarmos em seu lugar um cálculo frio sobre o QI futuro e sobre classificação nos exames, mataremos o jogo, para nós mesmos e para o bebê. Se nos mantivermos com esse espírito, os bebês logo se recusarão a jogar. E, quando jogarem, brincarão com um espírito escolar, quer dizer, brincarão apenas por acharem que ficaremos desapontados ou zangados se eles não o fizerem."

${ }^{293}$ John Holt. Como as Crianças Aprendem. Tradução de Walther Castelli Jr. $2^{\mathrm{a}}$ ed. Campinas, SP: Verus Editora, 2010, p. 14-15.
} 
É exatamente antes de ingressar na escola que as crianças têm suas melhores experiências de aprendizagem. São muitos os especialistas que, embora divirjam quanto às razões do fato, estão de acordo com esta afirmação. Acredito, e tento mostrar aqui, que na maioria das situações nossa mente funciona melhor quando a utilizamos de determinada forma. E acredito também que as crianças tendem a aprender melhor que os adultos, e melhor do que aprenderão quando se tornarem mais velhas, porque utilizam a mente de uma forma especial. Em síntese, as crianças têm um estilo de aprendizagem apropriado a sua condição e que elas dominam com naturalidade até que as desviemos de seu caminho. Gostamos de dizer que mandamos as crianças para a escola para ensinar a elas como pensar. O que de fato fazemos, quase sempre, é ensiná-las a pensar mal e precariamente, a desistir de uma forma de pensar natural e poderosa para adotar um método que não funciona bem para elas e que nós mesmos raramente utilizamos. ${ }^{294}$

É importante ressaltar que John Holt sempre foi professor, e como ele mesmo diz, era aquele professor que se aparelhava de todo tipo de recurso que tomasse a atenção de seus alunos. E mesmo assim, percebeu algum tempo depois, que só o fato de ensinar já trazia o desinteresse do aluno, ou ainda, a vontade de aprender apenas para obter compensação.

Seus relatos são fiéis às observações vivenciais. Ele, de fato, experimentou deixar as crianças completamente à vontade, para depois anotar como investigavam o mundo a seu redor.

E foi a partir desta observação que realmente se convenceu que as crianças aprendem mais quando livres. Os livros a que tivemos acesso tratam dessas experiências vivenciais.

Cada criança tem um processo de aprendizagem próprio, autônomo, e diferente de qualquer outra, e somente um olhar carinhoso e profundamente respeitoso nesse sentido pode possibilitar à criança o seu desenvolvimento pleno, e o desabrochar de sua verdadeira potencialidade.

John Holt entende que qualquer interferência de um adulto nesse processo é sempre perniciosa, e na maioria das vezes, pode provocar o embotamento dos potenciais originais das crianças.

\footnotetext{
${ }^{294}$ John Holt. Como as Crianças Aprendem. Tradução de Walther Castelli Jr. 2ª ed. Campinas, SP: Verus Editora, 2010, p. 13-14.
} 
Ele diz que as crianças são muito espertas e sensíveis às expectativas dos adultos, e tão logo percebem o que delas se espera, passam a atuar conforme o esperado, anulando sua espontaneidade e originalidade.

E essa percepção vai aumentando na mesma proporção da idade, de forma que quanto mais velha a criança for, mais dissimulada, e com melhores estratégias agirá para enganar e esconder o que pensa, sente ou faz.

Ele diz que a única coisa que pode ser feita pelos adultos para ajudar as crianças no processo de aprendizagem é tornar o mundo e as pessoas mais acessíveis e transparentes a elas. Ele entende que a palavra-chave é acesso. Acesso às pessoas, aos lugares, às experiências, aos locais de trabalho e a outros tantos lugares aonde vamos, como países, cidades, ruas, construções.

De seus livros, percebe-se claramente a convicção de que as crianças melhor aprendem quando podem participar mais de perto do mundo real. Que seu interesse é nas coisas dos adultos, e que quando lhes franqueamos a entrada no nosso mundo, a curiosidade faz o resto, fluindo o aprendizado de forma natural. ${ }^{295}$

Para John Holt, a criança tem uma curiosidade desinteressada, e para que isso não se perca, é imprescindível um trabalho educacional sensível. ${ }^{296}$

Por outro lado, as escolas, com seus currículos de disciplinas intensos, não têm como oferecer aos alunos esse olhar compreensivo e sensível; não havendo, na maior parte do tempo, possibilidade de discussões sobre as mais variadas questões elaboradas pelas crianças. Não há tempo a perder. Há um cronograma a ser cumprido.

\footnotetext{
295 “Creio até hoje - na verdade, hoje mais que naquela época - que, sob todos os aspectos, é útil para as crianças observar os adultos trabalharem de verdade e, sempre que possível, ajudá-los em suas tarefas. Uma das grandes vantagens da educação feita em casa é que as crianças que não estão trancadas na escola têm a chance de observar seus pais e outros adultos em seus afazeres e, se desejarem, juntar-se a eles." (John Holt. Como as Crianças Aprendem. Tradução de Walther Castelli Jr. 2ª ed. Campinas, SP: Verus Editora, 2010, p. 86).

296 "Mas sua paixão sempre foram as crianças, nas quais ele via a possibilidade de um mundo melhor, se fôssemos capazes de fazer com elas um trabalho educacional compreensivo, sensível e respeitoso, de forma preservar o que há de essencialmente bom nelas e que é também o melhor do gênero humano: a curiosidade desinteressada pelo sentido das coisas. Nesse trabalho, Holt lembra que os pais exercem um papel fundamental." (John Holt. Como as Crianças Aprendem. Tradução de Walther Castelli Jr. $2^{\mathrm{a}}$ ed. Campinas, SP: Verus Editora, 2010, p. 11-12).
} 
Dentre as muitas razões de que o autor é contrário à escola, cremos que a principal diz respeito justamente à falta de tempo dos professores para atender às constantes perguntas dos alunos. Ele entende que aquele aluno, que está comprometido em aprender, mais que passar nos exames, certamente enfrentará dificuldades, pois estará sempre fazendo perguntas, não sendo bem recebido por isso.

De fato, com uma grade curricular tão extensa, com grandes conteúdos a serem transferidos aos alunos, fica impossível um atendimento personalizado. Na maioria das vezes, o aluno é ignorado, ou ainda pior, chacoteado por seus colegas.

Logo aprendem a guardar para si suas indagações, seus incômodos, e pouco a pouco, perdem o desejo de explorar o mundo, a espontaneidade, a originalidade, e se desconectam com a sua essência, seu pulsar.

Infelizmente, tanto as escolas como os professores estão ocupados em alfabetizar as crianças, no ensino fundamental, e depois capacitá-las, para ingressarem no mundo, conseguindo bons empregos, e o almejado sucesso.

Poderiam ser citados mais trechos dos livros publicados no Brasil por John Holt, e estender a discussão sobre o porquê ele entende muito melhor deixar as crianças livres para aprenderem, segundo sua vontade, mas o objeto deste item era apenas pontuar a existência de pessoas que entendem que a educação formal estigmatiza e massifica as crianças, fato que poucos questionam, e compreendem como uma grande perda para a humanidade.

Por esta razão, apenas para encerrar o pensamento dele, segue descrição, no sentido de que a educação formal é governada e dominada por três metáforas.

A educação formal é governada e dominada por três metáforas particulares. Alguns educadores estão mais ou menos conscientes de que seu trabalho é guiado por tais metáforas. Outros não têm a menor consciência disso. E outros, ainda, podem até chegar a negar vigorosamente sua influência. No entanto, conscientes ou não, elas têm determinado amplamente o que a maioria dos professores faz na escola. A primeira dessas metáforas apresenta a educação como uma linha de montagem em uma fábrica de enlatados ou engarrafados. Penduradas nas esteiras estão filas de recipientes vazios de diferentes formas e tamanhos. Ao lado delas, uma série de aparelhos de esguinchar, controlados pelos empregados da fábrica. À medida que os recipientes passam, os empregados esguicham em seu interior variadas quantidades de diferentes substâncias - leitura, ortografia, matemática, história, ciências. No andar de cima, os gerentes decidem quando os recipientes devem ser postos na esteira, quanto tempo devem ser deixados nela, que tipos de substâncias devem ser postos neles de cada vez e o que deve ser feito com aqueles recipientes cujas 
aberturas parecem menores que as dos outros e com aqueles que parecem não possuir nenhuma abertura. [...] Uma segunda metáfora retrata os alunos na escola como ratos de laboratório em uma gaiola, sendo treinados para fazer algum tipo de truque. Na maioria das vezes, um tipo de truque que nenhum rato na vida real teria qualquer razão para fazer. Põe-se, por exemplo, o rato em um lado da gaiola e, no outro, um triângulo e um círculo. Se o rato pressiona a figura "certa" - aquela que o experimentador quer que ele pressione -, lá vem uma saborosa recompensa. Se o rato pressiona a figura "errada", a indesejada, recebe um choque elétrico. [...] Digo que assim é o ensino ainda hoje: tarefa, recompensa, choque. No lugar de recompensa e choque leiam-se promessas e ameaças, ou "reforço positivo" e "reforço negativo". Os reforços positivos na escola são sorrisos dos professores, medalhas, notas altas nos boletins, classes especiais e, no fim, o ingresso em faculdades prestigiadas, a conquista de bons empregos, trabalhos interessantes, dinheiro e sucesso. O reforço negativo são reprimendas raivosas, sarcasmo, desprezo, humilhação, vergonha, o riso derrisório das outras crianças, as ameaças de fracasso, de ficar para trás, de ser expulso da escola. Para muitas crianças desafortunadas, os reforços negativos incluem castigos físicos. Ao fim dessa linha, estão a admissão em faculdades de segunda ou terceira categoria ou a impossibilidade de cursar uma faculdade, o desemprego ou empregos ruins, trabalho duro, pouco dinheiro ou absoluta pobreza. A terceira metáfora é, talvez, a mais destrutiva e perigosa de todas. Apresenta a escola como um hospital para alienados mentais. As escolas, de alto ou baixo nível, têm operado sob a regra, maravilhosamente conveniente para elas, de quando ocorre aprendizagem o crédito é delas: "Se você pode ler, agradeça a um professor", e de quando não ocorre aprendizagem, a culpa é dos alunos. Em uma escola de ensino fundamental muito bem cotada, um professor veterano chegou a afirmar: "Se as crianças não aprendem o que ensinamos, é porque são preguiçosas, desorganizadas ou têm distúrbios mentais”. À exceção de uns poucos professores, a maioria concordou com ele. Mais recentemente, no entanto, os educadores encontraram outra explicação para a não-ocorrência de aprendizagem: "deficiências de aprendizagem". Essa explicação se tornou popular porque oferecia um argumento a todos os envolvidos nesse assunto. Pais de classe média necessitados de se livrar da culpa pelo fracasso dos filhos puderam parar de perguntar: "O que fizemos de errado?". Os especialistas lhes diziam: "Vocês não fizeram nada de errado; o problema é só o fato de que seu filho tem uns parafusos soltos na cabeça". Podia-se dizer aos que, já com certa ira, cobravam às escolas que "fizessem seu trabalho e ensinassem algo às crianças": "sinto muito, mas nada podemos fazer; seu menino tem deficiências de aprendizagem”. ${ }^{297}$

A educação, talvez, seja um dos temas mais difíceis de tratamento, pelo fato de envolver o lado subjetivo das pessoas, suas opções religiosas, suas formas de enxergar a função do professor, e principalmente o papel do educando.

O que se pretendeu aqui foi apenas trazer ao conhecimento o pensamento de um antigo professor, que se indignou com o modo que as crianças eram tratadas na escola, de forma que tinham suas originalidades cortadas pela raiz.

\footnotetext{
${ }^{297}$ John Holt. Aprendendo o tempo todo: como as crianças aprendem sem ser ensinadas. Tradução de Walther Castelli Jr. Campinas, SP: Verus Editora, 2006, p. 169-170. (destaques nossos).
} 
As pessoas não questionam a ditadura do currículo, pelo contrário, o referendam. Ninguém contesta a razão de se estudar determinadas disciplinas, ao invés de outras. Não há indagação da grade curricular fechada, do ensino uniforme. Não se perquire as inclinações pessoais dos alunos. Não há espaço para o livre, o despertar, desabrochar de interesses das crianças.

\begin{abstract}
Não existe consenso a respeito do que deve ser transmitido a uma criança. Inúmeras informações lhe são fornecidas, sem a menor justificativa lógica da inclusão desses elementos no seu aprendizado. Já se afirmou que a criança é naturalmente inteligente na sua espontaneidade pré-escolar e que o ensino institucionalizado comete a façanha de imbecilizá-la. ${ }^{298}$
\end{abstract}

A cada dia que passa, o fracasso da educação é matéria jornalística. Evasão escolar, baixos índices nas avaliações de ensino, maus tratos, deficiências de aprendizado, bulling.

Temos que estes acontecimentos têm ligação com a educação dirigida de forma uniforme a todas as crianças, sem considerar o universo único que existe em que cada uma delas.

John Stuart Mill, já no século XIX, em seu grande clássico Sobre a Liberdade, dizia que:

A natureza humana não é uma máquina a ser construída segundo modelo, e destinada a realizar exatamente a tarefa a ela prescrita, e sim uma árvore que necessita crescer e desenvolver-se de todos os lados, na conformidade da tendência das forças internas que a tornam uma coisa viva. ${ }^{299}$

E continua, dizendo que:

Não há razão para que toda a existência humana se construa por um só modelo, ou por um pequeno número de modelos. Se se possui tolerável soma de senso comum e de experiência, o modo próprio de dispor a existência é o melhor, não porque seja o melhor em si, mas porque é o próprio. Os homens não são como carneiros, e mesmo os carneiros não são indistintamente iguais. Um homem não

\footnotetext{
${ }^{298}$ José Renato Nalini. Formação do Juiz. In: José Renato Nalini (Coord.). Formação Jurídica. São Paulo: RT, 1994, p. 133.

299 John Stuart Mill. Sobre a Liberdade. Tradução de Alberto da Rocha Barros. 2a ed. Petrópolis, RJ: Vozes, 1991, p. 100-101. (destaques nossos).
} 
pode adquirir um casaco ou um par de botas que lhe sirvam sem que tenham feito à sua medida, ou sem que os escolha dentre um completo sortimento - e é, porventura, mais fácil provê-lo de uma vida do que de um casaco? Ou serão as criaturas humanas mais semelhantes entre si pelo conjunto da formação física e espiritual, do que pelo feitio dos pés? Se os indivíduos só apresentassem diversidades de gosto, já haveria nisso razão suficiente para não se tentar talhá-los por um único modelo. Mas, além disso, pessoas diferentes requerem condições diferentes de desenvolvimento, e a identidade de atmosfera e clima moral pode não lhes convir mais do que convém à generalidade das espécies de plantas a identidade de atmosfera e clima físico. Aquilo que auxilia o cultivo da natureza mais elevada de um, impede-o a outro. Para um, certo modo de vida é estímulo sadio, mantendo na melhor ordem as suas faculdades de ação e de gozo; para outro, é carga pesada que paralisa ou aniquila toda a sua vida interna. A diversidade das fontes de prazer, das disposições para a dor, dos efeitos íntimos das várias ações físicas e morais, é tal nos seres humanos que eles não obtêm o seu justo quinhão de felicidade, nem se elevam à estatura mental, moral e estética de que a sua natureza é capaz, sem que exista uma correspondente diversidade nos seus modos de vida. ${ }^{300}$

Passados quase dois séculos da constatação de John Stuart Mill, e o homem continua desconsiderando a natureza diversa das pessoas, para impingir-lhes a mesma educação, de forma uniformizada e massificada.

Como bem pontuado por Elza Antonia Cunha Boiteux, "A educação dos sentimentos é uma preocupação moderna, ainda que autores clássicos se tenham dedicado a ela. Durante séculos, o sistema tradicional de educação procurou apenas se dirigir ao âmbito intelectual e racional. A dimensão interna precisa de aperfeiçoamento para chegar ao ideal, e o ideal é fazer com que, desde a mais tenra idade, as pessoas se habituem a considerar os seus próprios sentimentos e, a partir da adolescência, as suas próprias paixões. Todo ser humano é a um só tempo razão e sentimento."301

Temos negligenciado o tratamento dispensado às nossas crianças. Continuamos tratando-as como "gente pequena", no entanto, sem atribuir-lhes os mesmos direitos de gente. E os direitos, aqui referidos, não significam amparo legal.

Para nós não existe direito nem justiça, somos uma classe oprimida", escreve o "pequeno autor". No mundo dos adultos a criança "não tem importância": é tratada

\footnotetext{
${ }^{300}$ John Stuart Mill. Sobre a Liberdade. Tradução de Alberto da Rocha Barros. $2^{\mathrm{a}}$ ed. Petrópolis, RJ: Vozes, 1991, p. 109. (destaques nossos).

${ }^{301}$ Elza Antonia Pereira Cunha Boiteux. Educação e Valores Ambientais. In: Elza Antonia Pereira Cunha (coord). Direitos Humanos: estudos em homenagem ao Professor Fábio Konder Comparato. São Paulo: Editora Jus Podivm, 2010, p. 36.
} 
com desatenção, menosprezo, impaciência. Eles sempre têm mais o que fazer do que se incomodar com as "puerilidades" das crianças. ${ }^{302}$

Falta sensibilidade e delicadeza para compreender as preciosidades que são as crianças; falta pureza para lidar com seus sentimentos.

Qual é o adulto que entende que "se ele me deu os patins de presente, se o presente é meu, então posso fazer o que quiser com eles"? (No caso, trocar os patins com um colega por um cobiçado estojo.) Qual é o adulto que compreende que uma criança pode querer ficar triste: "A tristeza não é ruim, é um sentimento suave e agradável", sem que isso seja causa de reprimendas e "cobranças"? Quem entre os adultos reconhece a sexualidade infantil, o amor de uma criança por outra? Ou respeita as lágrimas infantis? Por que eles não entendem que "os vidros quebram, as molas (do sofá) arrebentam, as calças rasgam" - e não é por perversidade proposital da criança ${ }^{303}$

Relacionando tudo quanto acima exposto com o julgador, que é o objeto deste capítulo, pergunta-se como esperar mudanças na forma de ingresso na magistratura, se as crianças são preparadas para abafar seus instintos e desejos originais, procurando carreiras que lhes dêem segurança? Como esperar o questionamento dos candidatos de sua real vocação, de seus propósitos originais? Pior, como esperar que falem a verdade?

Dizer a verdade, nestes casos, pode acarretar ser vetado no concurso e, por isso, certamente, quando questionados, dizem que é vocação. Jamais dirão que, muita vez, o que os movem é a estabilidade econômica, social, o poder, ou que sequer se lembram do que realmente gostariam de trabalhar na vida.

José Renato Nalini, há tempos assim já se manifesta, ao falar que "O treino oficial para os concursos faz com que todos os candidatos ofereçam a mesma resposta: Por vocação! Por ideal! Sempre pensei em ser juiz! Ninguém se atreveria a dizer: Preciso de emprego! Tenho família para sustentar! Preciso me casar e não tenho salário! Não dei certo na advocacia!

\footnotetext{
302 Apresentação de Tatiana Belinky in Janusz Korczak. Quando eu voltar a ser criança. Tradução de Yan Michalski. São Paulo: Summus, 1981, p. 10.

${ }^{303}$ Apresentação de Tatiana Belinky in Janusz Korczak. Quando eu voltar a ser criança. Tradução de Yan Michalski. São Paulo: Summus, 1981, p. 10.
} 
Estou prestando todos os concursos porque a carreira pública ainda é uma boa opção num Brasil globalizado com incertezas ditadas pelos globalizantes! ",304

Para julgar um humano, o juiz precisa ser cada vez mais humano ${ }^{305}$. Como exigir isso do julgador, quando, desde muito cedo, não foi tratado como humano, mas sim como máquina, um computador de duas pernas, programado para desejar, sentir e se comportar, conforme as regras pré-determinadas, sem espaço para manifestar sua real potencialidade? Ainda quando bebê, até seu choro era interpretado e rotulado!

O ser humano precisa evitar verdades emprestadas, referenciais externos, e procurar escutar seu coração. Desde muito pequenos, como dito acima, somos acostumados a abafar nossos sentimentos, somos ensinados a ser comedidos, a valorizar o que é do outro, o que vem de fora, esquecendo e nos afastando daquilo que carregamos dentro de nós, que é nossa força original.

O panorama conferido acima é apenas para aguçar o questionamento de que não há qualquer preocupação com o "ser” que habita cada indivíduo. Ninguém quer saber se as pessoas são felizes profissionalmente, se exercem seu dom divino. E tal descaso se estende também à carreira da magistratura.

O objetivo da Justiça é prover-se dos mais capazes, dos mais cultos, dos mais preparados. E estes são aqueles que conseguem responder às perguntas da Comissão. Não é problema da Justiça indagar se eles vão ser pessoas realizadas, satisfeitas ou felizes no desempenho funcional. ${ }^{306}$

Poucos são os que mesmo machucados, moídos em seus sentimentos, conseguem, bravamente, questionar as convenções, e ultrapassá-las, ainda que, sob o risco de grave julgamento externo, para dar vazão à voz de seus corações. Poucos têm coragem e integridade para serem eles próprios, abrindo mão da aprovação dos outros.

\footnotetext{
${ }^{304}$ Prefácio de José Renato Nalini in Lídia Reis de Almeida Prado. O Juiz e a Emoção: aspectos da lógica da decisão judicial. Campinas: Millennium Editora, 2003, p. XIV. (destaques do autor).

${ }^{305}$ Prefácio de José Renato Nalini in Lídia Reis de Almeida Prado. O Juiz e a Emoção: aspectos da lógica da decisão judicial. Campinas: Millennium Editora, 2003, p. XI.

${ }^{306}$ Prefácio de José Renato Nalini in Lídia Reis de Almeida Prado. O Juiz e a Emoção: aspectos da lógica da decisão judicial. Campinas: Millennium Editora, 2003, p. X.
} 
Os que permanecem encaixotados e que, portanto, estão desajustados, uma vez que em dissonância com o seu pulsar vital, não têm como dar aquilo que não receberam. Serão almas sem vida, vagando por aí, buscando no outro aquilo que não encontram dentro de si.

Pior, passam a vida inteira fugindo da responsabilidade, atribuindo todo o mal que se lhe aflige aos outros, sendo imaturos.

Neste item, pretendeu-se deixar claro que somos criados e ensinados a não manifestar a nossa verdade original e, como consequência, a não considerar a dos outros. Fomos condenados a não descobrir nossa real potencialidade (dom), uma vez que as poucas tentativas nesse sentido são, desde a infância, tolhidas na raiz. Não há interesse de conhecer a verdade das pessoas.

Há uma passagem digna de nota no livro O Pequeno Príncipe, que particularmente resume essa criação voltada à desconsideração das belezas particulares de cada indivíduo, valorizando-se a padronização.

É a parte em que o autor conta que, com seis anos de idade, após ter visto num livro informações de que a jiboia engolia as presas inteiras, sem mastigar, fez um desenho que refletia este novo conhecimento; e que ao mostrar e questionar um adulto se o desenho lhe causava medo, foi surpreendido com a resposta negativa, uma vez que não era possível um chapéu causar temor.

Insistindo no tema de que não se tratava de um chapéu, mas sim de uma jiboia engolindo um elefante, aprimorou a figura, desenhando o interior da cobra, com o elefante dentro, e novamente submeteu ao crivo do adulto, tendo ouvido o seguinte:

As pessoas grandes aconselharam-me a deixar de lado os desenhos de jiboias abertas ou fechadas e a dedicar-me de preferência à geografia, à história, à matemática, à gramática. Foi assim que abandonei, aos seis anos, uma promissora carreira de pintor. ${ }^{307}$

Diante desse quadro de descaso, que acarreta um verdadeiro condicionamento do ser humano, para desconsiderar as especialidades e particularidades de seus pares, desde o

\footnotetext{
${ }^{307}$ Antoine de Saint-Exupéry. O pequeno príncipe: com aquarelas do autor. Tradução de Dom Marcos Barbosa. Rio de Janeiro: Agir, 2009, p. 8.
} 
processo de criação e educação, chega a ser um verdadeiro disparate e, até mesmo, uma contradição, a exigência da verificação destas particularidades tão subjetivas, por força de lei, quando da aplicação do artigo 59 do Código Penal.

Para o fechamento deste item, relacionando com o tema do trabalho, que é justamente o questionamento da existência da conduta social e personalidade, como critérios a serem analisados pelo julgador, para fixação da pena-base, tem-se por, no mínimo, curioso que, em um mundo treinado para desvalorizar as diferenças, e seguir atropelando-as, haja uma lei, que dite uma consideração, uma valoração de critérios altamente subjetivos, que o ser humano, por sua criação, acostumou-se a renegar.

No próximo item, seguindo a ideia de que a criação da criança no sentido de evitar exteriorizar seus sentimentos originais promove um distanciamento dela mesma e, por consequência, um adulto separado, pretende-se desenvolver o raciocínio de que alguém que desconhece a si mesmo não pode pretender conhecer o outro.

\title{
4.2 Conhecer o outro exige que primeiro conheça-te a ti mesmo ${ }^{308}$
}

\begin{abstract}
Um homem tem muitas peles, cobrindo as profundezas do seu coração. O homem conhece muitas, muitas coisas; ele não conhece a si mesmo. Ora, trinta ou quarenta peles ou couros, como que de boi ou urso, muito espessas e duras, cobrem a alma. Entre no seu próprio território e aprenda a conhecer-se lá. ${ }^{309}$
\end{abstract}

\footnotetext{
308، Quando Sócrates, o primeiro filósofo a estimular o autoconhecimento em seus discípulos, ouviu de Querofonte que o oráculo o considerara o homem mais sábio da Grécia, ele resolveu examinar a afirmação. Chegou à conclusão de que não era digno da honraria e proferiu outra frase pra lá de conhecida: "Só sei que nada sei." Para ele, a verdadeira sabedoria seria o autoconhecimento, capaz de livrar a humanidade de falsos conceitos." (trecho da entrevista de Ruy Cesar do Espírito Santo concedida a Vitor Casimiro, no site Educacional, em junho de 2001, cujo título foi Uma aula sobre si mesmo. Disponível em: <http://www.educacional.com.br/entrevistas/entrevista0065.asp >. Acesso em: 27 nov. 2013.

309 Meister Eckhart apud Eva Pierrakos, Donovan Thesenga. Não Temas o Mal: o método pathwork para a transformação do eu inferior. Tradução de Sérgio Luiz dos Reis Lassere. São Paulo: Editora Cultrix, 2010 , p. 19.
} 
Neste item, pretende-se avançar a pesquisa no sentido de que o modelo de criação da separação, que se vive, afasta as pessoas delas mesmas, e por consequência lógica impede aquele que não se conhece de olhar para o outro com olhar neutro, com compaixão.

Pretende-se, ainda, tratar do necessário processo de autoconhecimento, que todo ser humano precisaria, em algum momento da vida, enfrentar, para identificar padrões tão arraigados de comportamento, repletos de sentimentos e emoções distorcidas, para num processo subsequente, conseguir trabalhar o descondicionamento, mediante auto-observação.

Parte-se da hipótese de que a humildade para enxergar o outro com isenção de julgamentos só é alcançada por meio de longo e árduo processo de autoinvestigação, o qual obrigatoriamente passará pela retirada das máscaras, e acarretará o inevitável encontro com a própria sombra.

Quando é retirada a máscara que constitui a persona do indivíduo, aparece uma face desconhecida, o arquétipo da sombra. É o nosso lado escuro, onde moram todos os atributos que nos desagradam ou que nos assustam. As características que não aceitamos em nós são projetadas sobre o outro, seja ele nosso vizinho, nosso inimigo político ou figuras-símbolo, como 'o judeu', 'o negro', 'o homossexual'. Dessa maneira, permanecemos inconscientes do fato de que abrigamos tais figuras dentro de nós. Lançar luz sobre esses recantos escuros traz como resultado o alargamento da consciência, mediante o qual percebemos que não é "o outro" que está errado, mas nossa percepção dele. ${ }^{310}$

Dentro desse autoestudo, no qual serão reveladas as feridas advindas da vida não vivida em sua plenitude, uma das primeiras constatações a que se chega é a de que se atua no

${ }^{310}$ Lídia Reis de Almeida Prado. Luz e sombra na gênese dos direitos humanos. In: José Renato Nalini e Angélica Carlini (Coord.). Direitos Humanos e Formação Jurídica. São Paulo: Forense, 2010, p. 361. 
mundo, por meio de máscaras ${ }^{311}$. Tantas quantas forem necessárias, determinadas para cada situação da vida. ${ }^{312}$

As máscaras são colocadas e trocadas a depender do lugar onde está, da profissão que exerce, da imagem que pretende demonstrar e etc. E servem como proteção do indivíduo tanto externa como interna.

Externa, na medida em que garantem conforto a seu portador, permitindo-lhe transitar pelos mais diversos ambientes e ocasiões, adaptando-se a cada situação da vida, tudo com o objetivo de ser aceito.

E interna, porque protege o indivíduo da constatação de seu lado sombrio. Justamente aquele em que recaem todos os sentimentos menos nobres, todos os maus desejos, toda a maldade. Faceta essa que ninguém quer se deparar. E quando se depara, prefere negar.

Desde cedo, como visto no item anterior, o indivíduo é treinado para não manifestar suas qualidades (dons), já que a criação recebida desconsidera as peculiaridades das pessoas, reprimindo aquilo que não se amolda ao padrão externo. Logo, se já não é aceita a manifestação do bom, que dirá a do ruim.

Portanto, já que não há permissão para a manifestação das partes “más” existentes em todos os indivíduos, paulatinamente, também se aprende a negar a existência, até de si próprios. $^{313}$

${ }^{311}$ Sinônimo de "Persona: a palavra, de origem latina, designa a máscara usada pelos atores teatrais. Para a Psicologia Analítica, persona é o arquétipo que se refere à face que colocamos para enfrentar a vida social. Segundo Jung, ela nada tem de real e não passa de um compromisso entre o indivíduo e a sociedade, acerca do quê alguém parece ser o pai, filho, possuidor de um título, detentor de um cargo, etc. Assim, durante a existência, muitas personas são utilizadas reclacionando-se com um status social, uma atividade ou profissão, um papel familiar, isto é, com todos os compromissos necessários para a vida em sociedade." (Lídia Reis de Almeida Prado. Racionalidade e Emoção na Prestação Jurisdicional. In: David Zimerman e Antônio Carlos Mathias Coltro (Org.). Aspectos Psicológicos na Prática Jurídica. 3a. ed. Campinas, SP: Millennium Editora, 2010, p. 94).

312 "A persona tem crucial valor, pois sem ela seria inviável o enfrentamento da existência e a adaptação ao meio (trabalho, relações familiares, relações sociais). Problemas surgem quando o homem se identifica com esse arquétipo. Em tal circunstância, o indivíduo perde a noção de sua verdadeira identidade e do lado sombrio do próprio psiquismo. Como explica Jung (CW VIII2, \$230), essa pessoa, por estar identificada com a máscara social, deixa de ser real, ficando destituída de profundidade interior." (Lídia Reis de Almeida Prado. O Juiz e a Emoção: aspectos da lógica da decisão judicial. Campinas: Millennium Editora, 2003, p. 73).

313 “A sombra é, portanto e em termos bastante simples, aquilo que não se deseja ser. É como se a criança, após chegar ao mundo irradiando cada um de seus trezentos e sessenta graus (e o cículo é um forte símbolo da integridade), construísse, pouco a pouco, um muro divisório entre o aceitável e o inaceitável. Tal cisão interna força a consciência a identificar-se com os aspectos aceitáveis e a querer afastar de si os inaceitáveis."( Bruno 
Com a visão nublada, sequer em pensamento aceita-se a existência do mal dentro de si, que dirá reconhecer o desejo por ele.

Esse padrão de negação daquilo que é inerente a todo ser humano é o que acarreta que toda a maldade interna seja relegada aos porões do inconsciente, tornando a relação com tais conteúdos internos um misto de medo e atração.

Exemplo desta dicotomia é a dificuldade que temos de falar sobre coisas ruins, sempre com medo de atraí-las para nossas vidas. Certas coisas é melhor não se falar. Quem nunca foi avisado para não falar sobre a morte, para ela não escutar e se aproximar?

Esse é apenas um dos milhares de exemplos daquilo que nunca se fala, apesar de povoar todas as mentes humanas.

Chega a ser hilário, mas a realidade é que fomos criados para abafar, como já mencionado no início deste capítulo, nossas vontades originais e esconder a nossa parte sombria, até de nós mesmos.

Ocorre que não é evitando falar do mal que o expulsaremos de nossas vidas. Ao contrário, o processo é justamente o caminho oposto, pois na medida em que se dá voz a esses conteúdos internos, tão repudiados, inclusive por seus portadores, aos poucos a luz vai chegando, clareando, de forma que se dissipam, e se integram.

A verdade é que a natureza humana é dualidade. "A vida e a morte, o bem e o mal, a esperança e a resignação coexistem em todas as pessoas e manifestam sua força em todas as facetas da vida. Se sabemos o que é coragem, é porque também experimentamos o medo; se podemos reconhecer a honestidade, é porque já encontramos a falsidade. No entanto, a maioria de nós nega ou ignora nossa natureza dualista". 314

Assim já reconhecia Jean Jacques Rosseau, que em Confissões, declarou que:

Soe quando quiser a trombeta do juízo final: virei, com este livro nas mãos, comparecer diante do soberano Juiz. Direi altivo: "Eis o que fiz, o que pensei, o que fui. Disse o bem e o mal com a mesma franqueza. Nada calei de mau, nada acrescentei de bom; e se me aconteceu usar algum ornato indiferente, não foi nunca

Amabile Bracco. Carl Jung e o Direito Penal. Rio de Janeiro: Editora Lumen Juris, 2013, p. 63-64). (destaques do autor).

${ }^{314}$ Deepak Chopra et al. O Efeito Sombra. Tradução de Alice Klesck, São Paulo: Lua de Papel, 2010, p. 7. 
para preencher um vácuo da minha falta de memória. Talvez tenha imaginado ser verdadeiro o que eu acreditava que o devesse ser, porém jamais o que eu soubesse ser falso. Mostrei-me tal qual era: desprezível e vil quando o fui; bom, generoso, sublime, quando o fui; desnudei meu íntimo, tal como tu próprio o viste, Ente Eterno. Reúne ao meu redor a turba inumerável dos meus semelhantes; que eles ouçam as minhas confissões, que gemam com as minhas indignidades, que corem com as minhas misérias. E que, por sua vez, cada um deles descubra seu coração aos pés do teu trono, com a mesma sinceridade; e, após, que um só deles te diga, se ousar: Fui melhor que aquele homem. ${ }^{315}$

Cada um detém dentro de si tanto a bondade quanto a maldade, mas evita-se ao máximo entrar em contato com esse lado escuro, negando-o e relegando-o à sombra. "Fomos condicionados a temer o lado obscuro da vida, assim como o nosso."316

Há uma crença de que toda a maldade do mundo está fora, e que não se tem qualquer responsabilidade para o mal que existe. Ficamos chocados com as tragédias nos noticiários, com os crimes bárbaros, sem tomarmos consciência de que, de alguma forma, contribuímos com os acontecimentos. ${ }^{317}$

No entanto, quanto mais se corre da sombra, mais poder ela alcança, destruindo pouco a pouco as vidas. Essa força oculta que se apossa das decisões não pode ser negada, sob o risco de causar mais dor, sofrimento, tristeza e sujeição.

Esse é o entendimento de Nise da Silveira, quando diz que a medida da repressão da sombra será a medida de sua espessura e escuridão. Alertando, no entanto, que também na sombra poderão existir traços positivos: qualidades valiosas do indivíduo que não se desenvolveram em razão de condições externas adversas, ou porque a pessoa não teve energia bastante para levá-las adiante. ${ }^{318}$

\footnotetext{
315 Jean-Jacques Rousseau. Confissões. Tradução dos livros I a X de Rachel de Queiroz; livros XI e XII de José Benedicto Pinto. Bauru, SP: Edipro, 2008, p. 29.

${ }^{316}$ Deepak Chopra et al. O Efeito Sombra. Tradução de Alice Klesck, São Paulo: Lua de Papel, 2010, p. 8.

317 "Por que é agradável olhar para as coisas terríveis? Ver um acidente, alguém se afogando, uma bicicleta sendo quase esmagada por um carro, um ladrão sendo apanhado e coberto de pancadas? Talvez seja por isso que existem as guerras, porque as pessoas gostam de sangue e de perigo." (Janusz Korczak. Quando eu voltar a ser criança. Tradução de Yan Michalski. São Paulo: Summus, 1981, p. 111).

${ }^{318}$ Lídia Reis Almeida Prado. Luz e sombra na gênese dos direitos humanos. In: José Renato Nalini e Angélica Carlini (Coord.). Direitos Humanos e Formação Jurídica. São Paulo: Forense, 2010, p. 362.
} 
É preciso muita coragem para encarar a maldade interna, e para extrair da sombra a sabedoria que ela encerra no fundo da consciência de cada um. ${ }^{319}$

No processo de autoconhecimento, trabalha-se com poderosas resistências internas, que guerreiam com a efetivação da transformação, uma vez que é muito difícil ao ser humano renunciar suas tão bem conhecidas formas de sentir, pensar e agir, porque gradativamente, durante a vida inteira, foram ficando firmemente introjetadas e arraigadas no psiquismo. ${ }^{320}$

$\mathrm{Na}$ jornada da autoinvestigação, cedo ou tarde, o peregrino de si mesmo se deparará com seu lado incógnito, sombrio. Quanto maior abertura para aceitar a existência das vulnerabilidades, e reconhecer os maus hábitos, mais fácil será transpor-los. ${ }^{321}$

A sombra não é um problema a ser resolvido ou um inimigo a ser vencido, mas um campo fértil a ser cultivado. Quando mergulhamos as mãos em seu solo rico, descobriremos as sementes potentes da pessoa que mais desejamos ser. ${ }^{322}$

Não é possível compreender e ter compaixão pelo outro, quando inexiste entendimento de si mesmo.

E para encontrar a si mesmo, o processo é lento, árduo e sofrido, repleto de idas e voltas. Não funciona com pressa, e não tem termo certo. Só com muita paciência é que, dia após dia, caminha-se rumo à inteireza.

319 "O encontro com a Sombra requer muita honestidade pessoal. É preciso admitir que não somos quem pensávamos ser e que não existimos na grandiosidade que imaginávamos existir. É ínsito ao equilíbrio de quem julga a consciência das próprias limitações, dos valores e emoções reprimidos no inconsciente para que o conteúdo reprimido aflore ao consciente como Sombra fluorescente." (José Américo Abreu Costa. A Presença da Sombra na Sentença Criminal. In: David Zimerman e Antônio Carlos Mathias Coltro (Org.). Aspectos Psicológicos na Prática Jurídica. Campinas, SP: Millennium Editora, 2010, p. 287).

${ }^{320}$ David Zimerman. Uma Aproximação Entre o Perfil da Figura do Juiz de Direito e a do Psicanalista. In: David Zimerman e Antônio Carlos Mathias Coltro (Org.). Aspectos Psicológicos na Prática Jurídica. Campinas, SP: Millennium Editora, 2010, p. 602).

321 "Somente o trabalho com a Sombra, de ordem essencialmente prática, possibilita esse equilíbrio. Consiste no processo consciente e intencional de reconhecermos aquilo que havíamos ignorado ou reprimido. Isso implica uma terapia que recupere, tire da Sombra do inconsciente tudo o que foi rejeitado, reprimido em nome do ego ideal, estabelecendo uma nova ordem que explique o lado obscuro da personalidade. [...] Trata-se, na verdade, de um trabalho lento, de um processo de autoconhecimento e aceitação que demanda paciência e humildade. Afinal, o encontro com o lado sombrio da personalidade é extremamente doloroso e deve ser levado até o fim, pois, como lembra Tomás de Aquino, "Somente toques numa ferida se puderes curá-la"." (José Américo Abreu Costa. A Presença da Sombra na Sentença Criminal. In: David Zimerman e Antônio Carlos Mathias Coltro (Org.). Aspectos Psicológicos na Prática Jurídica. Campinas, SP: Millennium Editora, 2010, p. 286).

${ }^{322}$ Deepak Chopra et al. O Efeito Sombra.Tradução de Alice Klesck. São Paulo: Lua de Papel, 2010, p. 12. 
Essa jornada é eminentemente pessoal. E há que se ter bastante perseverança e disposição para adentrar nestes solos desconhecidos e desbravar estas terras nunca antes encaradas. Identificar as mazelas, olhar para elas, e enfrentá-las, por meio da expansão da consciência, que ocorre com a auto-observação. ${ }^{323}$

Para encontrar a sombra, é necessário procurá-la dentro de si, olhando diretamente para todas aquelas coisas que se sente, mas que não gosta de sentir; pensando na capacidade de odiar, invejar, agredir; na vontade de se vingar, ou naqueles momentos em que agradece pelos pensamentos serem privativos. ${ }^{324}$

O primeiro passo na busca da sombra é justamente aceitar que todo indivíduo é, a um só tempo, bem e mal, luz e sombra, claro e escuro, amor e ódio, generosidade e avareza, coragem e medo. Enfim, repleto de polaridades, ora de um lado, ora na outra extremidade.

É aceitar que todos possuem dentro de si outro "Eu" que, normalmente, é o causador de vexame, de vergonha, porque é o possuidor dos sentimentos "ruins" que gostaríamos não existissem, e que procuramos negar.

Há um poema de Ferreira Gullar, denominado Traduzir-se $e^{325}$, que, com o perdão do trocadilho, bem traduz essa natureza humana dual, ao falar das antinomias existenciais, inerentes a todo "ser" que se pretenda humano. A proposta do poema é descrever as naturezas opostas convivendo em uma mesma pessoa.

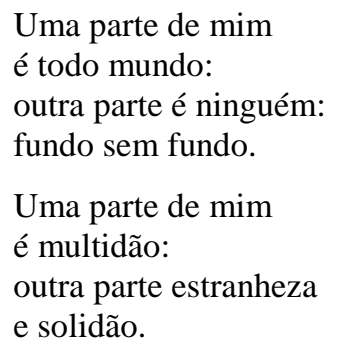

\footnotetext{
${ }^{323}$ Este caminho exige de um indivíduo aquilo que a maioria das pessoas está menos disposta a dar: verdade para consigo mesmo, exposição daquilo que existe agora, eliminação de máscaras e fingimentos e a experiência da sua vulnerabilidade nua. Isso é muito, e contudo é o único caminho que conduz à verdadeira paz e integridade." (Eva Pierrakos e Donovan Thesenga. Não Temas o Mal: o método pathwork para a transformação do eu inferior. Tradução de Sérgio Luiz dos Reis Lassere. São Paulo: Editora Cultrix, 2010, p. 15).

${ }^{324}$ Patrícia Gebrim. Gente que mora dentro da gente. São Paulo: Pensamento, 2004, p. 42.

${ }^{325}$ Este poema foi apresentado no livro Na vertigem do dia, publicado em 1980, de autoria de Ferreira Gullar. Disponível em: <http://www.passeiweb.com/na_ponta_lingua/livros/resumos_comentarios/n/na_vertigem_do_dia $>$. Acesso em: 20 set. $/ 2013$.
} 


\author{
Uma parte de mim \\ pesa, pondera: \\ outra parte \\ delira. \\ Uma parte de mim \\ almoça e janta: \\ outra parte \\ se espanta. \\ Uma parte de mim \\ é permanente: \\ outra parte \\ se sabe de repente. \\ Uma parte de mim \\ é só vertigem: \\ outra parte, \\ linguagem. \\ Traduzir uma parte \\ na outra parte \\ - que é uma questão \\ de vida ou morte - \\ será arte?
}

O poema inteiro revela a dualidade da natureza humana, porém a quinta estrofe é particularmente importante para a definição da sombra, na medida em que o poeta diz que uma parte sua é imutável, previsível, já a outra parte é sua desconhecida, e se manifesta subitamente. Querendo com isso dizer da parte sombria que todos os seres humanos possuem, e que é justamente a responsável pelas atitudes inesperadas e inexplicáveis. ${ }^{326}$

Segundo a Psicologia Analítica de Jung, somente a humildade de cada indivíduo, para lidar com seu próprio lado sombrio e assim descobrir seus limites, poderia ser um antídoto para a formação da sombra. Isso porque, segundo essa teoria, a sombra é perigosa quando negada, pois, nesse caso, o indivíduo ou grupo social projeta ${ }^{327}$ as próprias características

\footnotetext{
326 "O conceito de inconsciente causa impacto na medida em que propõe que o psiquismo humano se faz obrigado a represar em outra esfera, que não a exterior (consciencial, racional-volitiva), uma série de impulsos e afetos não condizentes com a cultura e a moralidade impostas. Longe de serem eliminados do psiquismo por uma racionalidade que lhes é muitas vezes inferior energeticamente, esses elementos seguiriam agindo através de pulsões constantes que praticariam "assaltos" à consciência, atuando muitas vezes às raias do incontrolável. É o preço da civilização: mal-estar." (Gabriel Antinolfi Divan. Decisão Judicial nos Crimes Sexuais: o julgador e o réu interior. Porto Alegre: Livraria do Advogado Editora, 2010, p. 84).

327 "Projeção: o conceito de projeção vem da Psicanálise, que a considera uma operação inconsciente, através da qual o indivíduo tira de si e coloca no outro (coisa ou pessoa) qualidades, sentimentos, desejos que lhe parecem inaceitáveis. A projeção não depende da vontade, pois é automática." (Lídia Reis de Almeida Prado. Racionalidade e Emoção na Prestação Jurisdicional. In: David Zimerman e Antônio Carlos Mathias Coltro (Org.). Aspectos Psicológicos na Prática Jurídica. $3^{\text {a }}$. ed. Campinas, SP: Millennium Editora, 2010, p. 94).
} 
destrutivas "nos outros", ficando escravos delas e sujeitos a serem dominados por ódios, julgamentos, preconceitos, agressividade etc. Tomar consciência da sombra seria a melhor maneira de torná-la menos espessa. ${ }^{328}$

\begin{abstract}
Muitas pessoas se assustam com a cara feia de seu Eu Inferior e, já que não podem acabar com ele, resolvem deixá-lo bem trancado na escuridão de uma caverna, fazendo de conta que a aparição do monstro não passou de um fruto da sua própria imaginação. Agem como se nunca sentissem raiva, tristeza, inveja ou esses sentimentos negativos que fazem parte de todos nós. Mas o que acontece é que preso, o monstro fica ainda mais bravo. ${ }^{329}$
\end{abstract}

Como visto acima, todos os seres humanos possuem esse lado sombrio que renegado acarreta uma série de consequências desastrosas, sendo que a única saída para o rompimento de tanta influência compulsiva seria a admissão da existência da sombra.

A partir desse mágico momento em que o buscador de si mesmo realmente compreende que abriga dentro de si várias partes ${ }^{330}$, vários Eu(s), e volta-se para um trabalho de autoinvestigação, o qual acarretará o fortalecimento do seu Eu Observador ${ }^{331}$, inevitavelmente, este peregrino será inundado pelo sentimento de compaixão ${ }^{332}$.

\footnotetext{
${ }^{328}$ Lídia Reis Almeida Prado. Luz e sombra na gênese dos direitos humanos. In: José Renato Nalini e Angélica Carlini (Coord.). Direitos Humanos e Formação Jurídica. São Paulo: Forense, 2010, v. 1, p. 363.

${ }^{329}$ Patrícia Gebrim. Gente que mora dentro da gente. São Paulo: Pensamento, 2004, p. 44.

330 "O reconhecimento interior não é só um exercício de memória, mas um esforço sério para ampliar a imaginação de modo que possa abarcar mesmo as possibilidades mais extremas e inusitadas. Você não pode fazer isso se não se dispõe a descobrir na sua alma monstros, heróis e santos que jamais suspeitaria encontrar lá." (Olavo de Carvalho. O Mínimo que você precisa saber para não ser um idiota. $5^{\mathrm{a}}$ ed. Rio de Janeiro: Record, 2013, p. 410).
}

331 “O Eu Observador é uma parte de você que consegue se afastar o suficiente para enxergar todos os outros eus, sem se misturar com eles.”[...]"Ele apenas identifica quem está presente. À medida que for aprendendo a reconhecer quem está se apresentando a cada momento, você vai começar a descobrir como lidar com os vários Eus de forma a criar mais harmonia na sua vida." (Patrícia Gebrim. Gente que mora dentro da gente. São Paulo: Pensamento, 2004, p. 111-113).

332 "Quando conectado ao seu Eu Observador você consegue olhar para si mesmo como se estivesse olhando de fora de você. Consegue olhar e reconhecer os outros Eus. Consegue identificá-los. Não julga, não condena a si mesmo, não se culpa, não se força a mudar, não divide as coisas em certo e errado. Observa com compaixão. Quando em contato com o Eu Observador, você não fica apegado aos outros Eus, e é capaz de mudar de um para outro pelo simples fato de estar tendo consciência deles. O Eu Observador é o que permite que sua consciência se expanda." (Patrícia Gebrim. Gente que mora dentro da gente. São Paulo: Pensamento, 2004, p. 134). 
A compaixão $0^{333}$ brotará tanto para si, abraçando estas partes relegadas aos porões do inconsciente, tão mal julgadas e reprimidas, como se expandirá externamente, despontando também para acolher a sombra dos outros indivíduos.

E esse despertar da consciência para a existência das mazelas humanas, que a todos nivela e iguala à condição de seres em evolução, acarretará um julgamento do semelhante o mais neutro possível.

Mais neutro, não porque isento de subjetivismo, mas porque pautado pelo reconhecimento da existência das projeções, dos preconceitos, e de todo conteúdo inconsciente que afeta as decisões, e por fim, pela compaixão, no sentido de respeito e acolhimento pela sombra alheia, pela simples constatação das polaridades havidas em todos os indivíduos, a exemplo do arquétipo juiz/réu.

Isso porque somente aquele que dá colo para si mesmo, que inclui e abraça o seu próprio Eu Inferior terá condições de dar colo para o Eu Inferior de outrem, e de fazer um julgamento o mais neutro possível, como dito acima.

Importante deixar claro que não se pretende, nesse momento, avançar os conceitos da psicanálise ou psicologia analítica, a fim de melhor esclarecer todos os processos de criação da sombra, de elaboração das máscaras, e dos diversos mecanismos de defesa, que os indivíduos desenvolvem, para se protegerem dos constantes choques de rejeição que recebem ao longo de suas jornadas na Terra.

Importantes escritos na área jurídica já atestam a necessidade da autoanálise dos magistrados, como saída para evitar sentenças desarrazoadas, em que se verifica claramente a presença dos conceitos irracionais e subjetivos, consistentes nas crenças, condicionamentos e pactos de vingança, projetados nas decisões.

\footnotetext{
333 "Joseph Campbell, cuja leitura me levou a caminhos de espiritualidade que refogem aos padrões dogmáticos das religiões tradicionais, sustenta que a grande herança judaico-cristã, qualquer que tenham sido os estragos feitos pela leitura literal dos textos bíblicos por muitos de seus ministros e sacerdotes ao longo da História, é o sentido da compaixão. Citando ninguém menos que Schopenhauer, ele nos ensina que a compaixão é uma identificação de alguém com uma pessoa que não é ele, uma ultrapassagem da barreira que existe naturalmente entre as pessoas, de tal maneira que o outro deixa de ser um estranho, passando a ser uma pessoa. Nesse processo, diz ele, transcrevendo o filósofo alemão, "eu sofro, a despeito do fato de sua pele não envolver meus nervos"”. (Adauto Suannes. Justiça \& Caos. Curitiba: Instituto Memória, 2008, p. 17).
} 
Nesse trabalho, não é possível traçar um histórico da origem da sombra, o que demandaria uma nova dissertação. E nem esse seria o objeto do estudo em questão. Ademais, já existem inúmeras obras da psicologia, mitologia e literatura, sem falar nas jurídicas de caráter interdisciplinar, que se desincumbiram dessa tarefa com maestria.

Mas a abordagem trazida neste capítulo relativa à criação pautada na cultura da separação, na busca de referencial externo, de adequação ao modelo exterior, e do completo afastamento do chamado interno, vez que desde muito cedo, os indivíduos são tolhidos, privados das mais básicas escolhas, e acostumados a esconder seus desejos; pretende demonstrar um dos possíveis percursos da criação da sombra, na medida em que tudo aquilo que não é plenamente vivido, porque reprimido, é empurrado para o inconsciente, e manifestase, sorrateiramente, através das projeções, nos mais diversos relacionamentos cotidianos da vida.

Feito este registro, as poucas considerações acima objetivam questionar a qualidade ou, até mesmo, a possibilidade de julgamento dos semelhantes sem o conhecimento prévio de si mesmo.

Esse estudo visa - mais que constatar a falácia do mito da neutralidade da atividade jurisdicional, tema já bem assentado pela doutrina brasileira e alienígena, uma vez que os julgadores não têm como se despir de suas histórias de vida, cultura, crenças, enfim, não se desvencilham de seu natural recorte de vida - reconhecer a necessidade de identificação do infrator que habita em todos os indivíduos, aceitando essa condição inerente ao ser humano, o que aproximará o julgador de seu réu e, inevitavelmente, ocasionará um julgamento mais sensível.

Sensível, na medida em que o julgador, sabedor das fragilidades humanas, e conhecendo, inclusive, as suas, certamente poderá bem melhor orientar seu julgamento de forma objetiva, abstendo-se de projetar todos os seus conteúdos internos sob a figura que se encontra diante de si.

Poderá, ainda, conhecendo essa natureza infratora dentro de si, e reconhecendo sua sombra, frear seus impulsos compulsivos, que causam verdadeiras tragédias, através das projeções. 
Aliás, esse é o entendimento de Lídia Reis de Almeida Prado, para quem os juízes, mais que qualquer outro profissional, deveriam entrar em contato com sua sombra.

\begin{abstract}
$\mathrm{O}$ ato de julgar implica a projeção, entendida como um mecanismo inconsciente, por intermédio do qual alguém tira de si e coloca no mundo externo (em outro, ou em alguma coisa) os próprios sentimentos, desejos e demais atributos tido como indesejáveis. Essa ligação entre julgamento e projeção traz um complicador, a formação de sombra. Por isso, creio ser importante que o juiz - mais talvez do que qualquer outro profissional - entre em contato com seus conteúdos sombrios, trazendo-os à consciência. Dessa forma, poderá talvez projetá-los menos. Isso ocorrerá se buscar entender o significado desse possível infrator que - como todo ser humano - tem dentro de si, reconhecendo-o como tal. ${ }^{334}$
\end{abstract}

Portanto, ao contrário de pretender resgatar uma pretensa neutralidade, nunca antes existente, nas decisões judiciais, quer-se alertar que não é a sua ausência que causa prejuízo aos julgamentos, mas sim a completa ignorância acerca dos aspectos psíquicos, metajurídicos e inconscientes que influenciam as decisões, por meio das projeções.

Miguel Reale, citando contribuição dos analistas ingleses do Século XVIII, com a chamada "Moral da simpatia", traz o pensamento de Adam Smith de que o ato de julgar é dos mais difíceis por pressupor a capacidade de colocar-se na posição do outro.

E avançando no tema, Miguel Reale dispõe que o acerto das decisões judiciais depende muito mais da capacidade psicológica dos julgadores, e até amorosa, com a possibilidade de colocar-se na posição do outro; concluindo que "neutralidade não consiste em ausentar-se das pessoas, fugindo delas, mas sim em se colocar compreensivamente na posição delas.”,335

José Renato Nalini entende que para os juízes "muito mais importante do que saber Direito é a pessoa conhecer-se, interessar-se pelo semelhante, condoer-se de alheio sofrimento. Depois, vontade de trabalhar, humildade, espírito público. „336

David Zimerman, psiquiatra por profissão, na mesma linha de Nalini, também entende que o juiz deve colocar-se no lugar do outro (condoer-se pela dor do outro), através da capacidade de ser continente, que significa a condição de conter dentro de si toda carga de

\footnotetext{
${ }^{334}$ Lídia Reis de Almeida Prado. O Juiz e a Emoção: aspectos da lógica da decisão judicial. Campinas: Millennium Editora, 2003, p. 49.

${ }^{335}$ Miguel Reale. A Ética do Juiz na Cultura Contemporânea. In: José Renato Nalini (Coord.). Uma Nova Ética para o Juiz. São Paulo: RT, 1994, p. 142.

${ }^{336}$ Prefácio de José Renato Nalini in Lídia Reis de Almeida Prado. O Juiz e a Emoção: aspectos da lógica da decisão judicial. Campinas: Millennium Editora, 2003, p. XV. (destaques do autor)
} 
necessidades, demandas e angústias que está sendo projetada nele, sem a devolução imediata, dizendo que "o que mais importa para o exercício do juiz é que ele tenha bem estabelecido o atributo da autocontinência, isto é, que ele consiga conter dentro de si as próprias angústias e sentimentos difíceis que lhe foram despertados pelo processo, de modo a poder mais tranquilamente poder decodificar, refletir, elaborar, dar um significado, um sentido e uma nominação para aquilo que vai se constituir a sua sentença." 337

E essa qualidade tão importante à judicatura não se alcança sem um mínimo de vontade de conhecer-se a si mesmo. ${ }^{338}$

Caminhando para a finalização desse item, então, buscou-se, nessa oportunidade, evidenciar que alguém que desconhece a si mesmo ${ }^{339}$, que ignora suas próprias vulnerabilidades, interagindo com seus semelhantes em posição superior, não tem condições de bem exercer a função judicante, pois não tem desenvolvida, dentre outras, a continência, qualidade inerente ao exercício da magistratura, como visto acima.

Deixou-se claro que a criação e a educação apartadas do chamado do coração e orientadas a abafar os mais primevos desejos, buscando-se referenciais externos, e a desconsideração das diferenças entre as pessoas, é portal para o incremento da sombra, cujo alimento é justamente a sua negação, mantendo-se a repressão no inconsciente, atuando clandestinamente através das projeções.

Ponderou-se que conhecendo a si próprio, ou pelo menos, trilhando um caminho de autoconhecimento, o julgador tomará consciência da existência desse Eu Inferior, que lhe

\footnotetext{
${ }^{337}$ David Zimerman. Uma Aproximação entre o perfil da figura do juiz de direito e a do psicanalista. In: David Zimerman e Antônio Carlos Mathias Coltro (Org.). Aspectos Psicológicos na Prática Jurídica. Campinas, SP: Milennium Editora, 2010, p. 605.

338 "Se incumbe à consciência aplicar a norma objetiva às circunstâncias e aos casos particulares, indeclinável a obrigação do ser humano em formar e aperfeiçoar o conhecimento íntimo de si próprio e de seus atos." (José Renato Nalini. Uma Nova Ética para o Juiz. José Renato Nalini (Coord). São Paulo: RT, 1994, p. 9).

339 “[...] um homem tem de estar livre de toda fiscalização externa para ter a certeza de que olha para si mesmo e não para um papel social - e só então pode fazer um julgamento totalmente sincero. Somente aquele que é senhor de si é livre - e ninguém é senhor de si se não aguenta nem olhar, sozinho, para dentro de seu próprio coração." (Olavo de Carvalho. O Mínimo que você precisa saber para não ser um idiota. $5^{\text {a }}$ ed. Rio de Janeiro: Record, 2013, p. 41).
} 
pertence, aceitando-o, e com isso compreendendo que todo ser humano também possui esta faceta interior, que é a grande responsável por todo o mal do planeta, e a partir desta constatação, interromper o processo de projeção de suas mazelas nos outros, libertando-se das suas programações.

Conhecendo a si próprio, certamente manifestações desarrazoadas como as abaixo seriam evitadas, uma vez que os julgadores teriam condições de compreender que não são seres supremos, sendo iguais a todos os outros que se submetem ao seu julgamento.

O Juiz de Direito não se confunde com a maioria dos homens. De 1000 (mil) Bacharéis em Direito que pretendem transformarem-se em Juiz de Direito, apenas 10 (dez), 05 (cinco), 01 (um) ou nenhum consegue realizar esse sonho. Esse tem sido o resultado da maioria dos concursos Públicos realizados para o provimento do Cargo de Juiz de Direito. Assim, apenas a minoria dos homens, a pequena fração de 0,01\% dos Bacharéis em Direito é capaz de moldar-se, converter-se em Juiz de Direito. Portanto o Juiz de Direito não está sujeito, exposto, aos sentimentos exagerados, como estão os outros homens em sua maioria. O Juiz de Direito emerge dentre os homens mais valentes, bravos, determinados, desasombrados, denodados, coerentes, sensatos, sensatos, educados, de melhor formação, tenazes, persistentes, resistentes, idealistas, íntegros, fabulosos, gigantes em virtude, elegantes, vencedores, campeões, melhores . [...] No desempenho de seu trabalho, nem o amor nem o ódio balizam a trajetória do Juiz de Direito. Para dá a cada um o que é seu, o Juiz de Direito orientase apenas pelo profissionalismo e pelo senso de Justiça." ${ }^{440}$

A liberdade de decisão e a consciência interior situam o juiz dentro do mundo, em um lugar especial que o converte em um ser absoluto e incomparavelmente superior a qualquer outro ser material. A autonomia de que goza, quanto à formação de seu pensamento e de suas decisões, lhe confere, ademais, uma dignidade especialíssima. Ele é alguém em frente aos demais e em frente à natureza; é, portanto, um sujeito capaz, por si mesmo, de perceber, julgar e resolver acerca de si em relação com tudo o que o rodeia. Pode chegar à autoformação de sua própria vida e, de modo apreciável, pode influir, por sua conduta, nos acontecimentos que lhe são exteriores. Nenhuma coerção de fora pode alcançar sua interioridade com bastante força para violar esse reduto íntimo e inviolável que reside dentro dele." ${ }^{\text {341 }}$

Essa mesma conclusão já apontou Lídia Reis de Almeida Prado, quando diz que o juiz que tem consciência da sua própria sombra, e que se coloca em condição de igualdade com seus jurisdicionados, pode prestar grande serviço ao Direito e a Justiça, nos seguintes termos:

\footnotetext{
${ }^{340}$ Trecho de despacho proferido pelo Juiz de Direito Carlos Antonio Alves da Silva, em 27/07/1994. Disponível em: 〈http://www.paginalegal.com/marcador/jurisprudencia/page/14/>. Acesso em: 29 set. 2013.

${ }^{341}$ Sentença proferida pela Juíza Titular Adriana Sette da Rocha Raposo, da Vara Única do Trabalho de Santa Rita-PB, nos autos do Processo 01718.2007.027.13.00-6, em 21/09/2007.
} 
Uma outra reflexão deve ser feita: o juiz todo-poderoso, que usa o direito positivo e a abstração para se esconder atrás do culto à neutralidade, não teria uma sombra mais espessa do que seu colega inglês? É possível, em termos humanos, que o juiz permaneça sempre capaz, equilibrado, eticamente sereno, sem mácula, enquanto que o outro, no caso aquele contra quem é movida a ação, continue sendo apenas o infrator? Por outro lado, o juiz que tem consciência da própria sombra pode, sem dúvida, prestar um grande serviço ao Direito e à Justiça. Vou chamá-lo de julgadorjulgado, porque entendo que essa denominação bem expressa o magistrado que embora procure orientar sua vida e seu trabalho pela legalidade e pela ética - sabe que contém, como possibilidade, aquele condenado anterior. ${ }^{342}$

Não se pretende com estes apontamentos afirmar que os julgadores não deverão mais julgar, ou que ficarão inaptos, uma vez que, por meio do autoconhecimento, adquirirão consciência de que não existem culpados ou inocentes, vítimas ou algozes, sendo todos os seres apenas atores de suas histórias, aprendendo, representando, errando juntos. Definitivamente, esta não é a conclusão a que se pretende chegar, até porque inviabilizaria o próprio ato de julgar.

Pretende-se apontar que ampliando a consciência, pelo autoconhecimento, cada vez mais, os julgadores concederão espaço interno para que seu Eu Observador perceba os diversos $\mathrm{Eu}(\mathrm{s})$ internos, que atuam dentro de si, nos mais variados momentos da vida, incluindo-se o próprio exercício de julgar, sendo-lhes possível, identificar, portanto, quando estão reagindo de forma programada, causando prejuízos aos jurisdicionados, ou seja, quando estão projetando sua própria sombra.

Embora os talentos individuais sejam multiformes e cada ser humano chamado a exercer a missão de julgar possa privilegiar uma determinada feição de seu temperamento, o juiz deve procurar o equilíbrio para um desempenho eficiente. Equilíbrio resultante de seu autoconhecimento. ${ }^{343}$

Esse também é o entendimento de Jacinto Nelson de Miranda Coutinho, quando diz que:

\footnotetext{
${ }^{342}$ Lídia Reis de Almeida Prado. O Juiz e a Emoção: aspectos da lógica da decisão judicial. Campinas: Millennium Editora, 2003, p. 47-48.

${ }^{343}$ José Renato Nalini. Formação do Juiz. In: José Renato Nalini (Coord.). Formação Jurídica. São Paulo: RT, 1994, p. 132.
} 
À coletividade interessa um juiz resolvido; e não aquele que se resolva judicando. Magistrado não é - e nem pode ser - analista. Colocado na posição de 'suposto Saber', deve dicere jus, isto é, juris dictio; e por evidente está muito mais para ortopedista do 'eu' (o behaviorismo não seria outra coisa) que para um terceiro, o qual, pela escuta, procura nas brechas do discurso encontrar a fala do sujeito, do Outro, para simplesmente pontuar situações discursivas e colocar o vivente em condições de conviver, ele mesmo, com o desejo. Mas não se põe - e nem pode -, o analista, como modelo, razão por que sabe - e deve saber, sob pena de impostura não se enlear no processo transferencial, essencial ao ato analítico. $\mathbf{O}$ magistrado, por elementar, não é assim. Quem aciona quer uma sentença que lhe reconheça o direito e, depois, satisfação quando ela é executada: o caso, assim, é levado para receber uma decisão, a qual, ainda que expressando aquilo que está sentindo o juiz (sentença, como se sabe, vem de sentire, do latim, gerúndio sentiendo), não é tão-só a vontade da lei (como articula o próprio Chiovenda e tantos continuam fazendo), não só porque ela não tem qualquer vontade, em hipótese alguma, mas porque o discurso decisional é impregnado de um Outro que fala pela sua fala; e do qual ele, juiz, nada sabe. ${ }^{344}$

A importância desta constatação relativamente à existência das circunstâncias judiciais conduta social e personalidade, na fixação da pena, revela-se crucial, na medida em que desconhecendo este caráter interno, o julgador não conseguirá identificar que tipo de projeção ocorreu quando tomou ciência, por exemplo, da conduta social do autor de um delito; ou ainda de sua personalidade, não tendo condições de abster seu julgamento da influência dos aspectos inconscientes, que operaram no momento da decisão.

Concluindo este item, entende-se que obrigar os julgadores a procurar conhecer-se melhor, para melhor trabalharem para a sociedade, não é algo possível, tampouco desejável, afinal de contas, seria também uma forma de repressão.

Como não é possível exigir que os magistrados entreguem-se a um processo de autoconhecimento, via única para alcançar a expansão da consciência, dissipando-se a ignorância sobre a influência dos aspectos internos nas decisões ${ }^{345}$, entende-se que este novo

\footnotetext{
${ }^{344}$ Jacinto Nelson de Miranda Coutinho. Jurisdição, Psicanálise e o Mundo Neoliberal. In: Jacinto Nelson de Miranda Coutinho et al. Direito e Neoliberalismo: Elementos para uma Leitura Interdisciplinar. Curitiba: EdiBEJ, 1996, p. 72-73. (destaques nossos)

345 “Tudo quanto até agora foi mencionado reforça a importância de o juiz ser verdadeiramente independente, e consciente de que tal independência deve ser praticada em relação a si mesmo, de maneira a afastar da atividade judicante aquilo que seja produto de posições pessoais suas, advindas da maneira como foi moldada a sua personalidade, ou mesmo de suas paixões e antipatias, naturais a todo e qualquer ser humano e que acabam, muitas vezes, ainda que, de forma inconsciente, a conduzi-lo a soluções afastadas daquilo que se tenha como conveniente e adequado aos casos que lhe caiba apreciar. A necessidade dessa consciência do que em si mesmo se passa adquire especial importância quando se trata dos magistrados, como forma de procurarem eles abrigar-se de influências, quer sejam elas internas, quer externas, e que possam comprometer o exercício da função sob o prisma de sua imparcialidade. Justamente por conta de que o elemento psicológico, seja ele consciente ou não,
} 
paradigma poderia, vagarosamente, ser introduzido no mundo jurídico, a começar pelo questionamento da atual formação jurídica no Brasil, passando, obrigatoriamente, pela análise crítica do modelo de recrutamento de juízes, e, por fim, chegando ao conteúdo e objetivo das escolas da magistratura. Tudo com o fim de prestigiar aquele que é o responsável pela prestação jurisdicional, e, em última instância, todos os jurisdicionados, que são os que sofrem com o trabalho mal executado.

É sobre este caminho intermediário, iniciando-se pelo repensar da atual estrutura da formação jurídica em nosso país, do modelo de ingresso dos juízes na carreira e da formação continuada, que pretendemos desenvolver o próximo item.

\subsection{Formação jurídica}

Como visto no início desse capítulo, estamos longe de atingir o estado ideal, em que os indivíduos reconhecerão o valor da cooperação (contrária à competição), que abre espaço para que todos ofereçam seus talentos ao mundo, por meio de uma educação que atrele o conteúdo pedagógico à intencionalidade amorosa, na qual além do aprendizado regular, os estudantes se desenvolverão como seres humanos e, nessa qualidade, poderão se tornar indivíduos realizados, escolhendo suas profissões, segundo seu chamado interno, sentindo-se, destarte, participantes no mundo (indivíduos socialmente colaborativos). ${ }^{346}$

acaba por interferir na atividade decisória, influenciando para melhor ou pior a conclusão a que chegue o juiz, torna-se imperioso ao julgador estar sempre atento para impedir que influxos próprios a sua personalidade ou mesmo a seu ideário e que não tenham a ver com a missão que lhe cabe, possam influenciar em sua forma de agir, seja para mais ou para menos." (Antônio Carlos Mathias Coltro. Uma Visão Humanística na Prática Judiciária. In: David Zimerman e Antônio Carlos Mathias Coltro (Org). Aspectos Psicológicos na Prática Jurídica. $3^{\text {a }}$. ed. Campinas, SP: Millennium Editora, 2010, p. 7).

${ }^{346}$ Hoje, já existe uma organização sem fins lucrativos, atuando em colaboração com a Secretaria Municipal da Educação da cidade de São Caetano do Sul-SP, chamada Instituto Alegria para um Mundo Melhor, cujos pilares de trabalho são a educação e a mediação de conflitos. Este Instituto, no âmbito da educação, tem como objetivo tornar possível conciliar a educação formal com a intencionalidade amorosa, e o faz através de oficinas que incluem espaços de silêncio, revisão de valores e crenças em situações cotidianas, contação de histórias, com foco em valores humanos, e partilha de sentimentos e aspirações. Nas palavras de Cynthia Ferrari, responsável pelo Instituto, este parte do pressuposto de que a paz é um desejo inerente ao homem, e que para entrar em contato com ela, de forma definitiva e legítima, a criança e o ambiente que a rodeia precisam aprender, desde cedo, a frequentar um universo que lhes darão respostas sobre si mesmas, para que este valor seja encontrado em cada um, e não em uma verdade emprestada que pode desmoronar no primeiro desafio. O que antes parecia um problema secundário às sociedades, hoje se faz de urgência: estudar os relacionamentos do nosso dia a dia para que possamos não somente conviver, mas aproveitar os benefícios da diversidade e das relações humanas. No 
E como ainda assim é, mesmo já havendo grande disposição de muitas organizações e educadores, com vistas a alterar esse paradigma, que lentamente já começam a plantar as sementes da educação do futuro, nesse item, pretende-se ponderar uma reflexão sobre o atual ensino jurídico brasileiro que, como não poderia ser diferente, também obedece à tônica educacional da separação, da competição, da obtenção de diploma, para conseguir empregarse no mercado de trabalho, mais que pelo exercício de vocação, o que contribui para manutenção do atual estágio da prática educacional, como um ciclo vicioso. ${ }^{347}$

Nessa linha do estudo com o objetivo de diplomar-se para conseguir bons empregos, arrisca-se dizer que o curso jurídico tem grande receptividade. E isso acontece por alguns motivos.

Um deles é, sem sombra de dúvidas, o fato de ser um curso, em que não se exige prática. Ainda que hoje em dia seja obrigatório estágio, ele está atrelado à disciplina de prática forense, existente apenas no último ano do curso, e se restringe ao cumprimento de algumas horas práticas, seja assistindo a audiências, seja elaborando petições, com supervisão do

Programa Florescer, desenvolvido por este Instituto, esta relação é estudada de dentro para fora, para que a paz se estabeleça a partir do conhecimento de si mesmo através da identificação dos pontos internos que alimentam a violência - manifestada não somente nos grandes eventos da humanidade, mas principalmente na convivência dos pequenos círculos relacionais. O modelo de educação necessário a uma sociedade moderna vai além dos conteúdos técnicos. A educação integral, que contempla o poder de conhecimento de si mesmo tanto quanto o saber curricular, é a única maneira de colocar em prática um movimento consciente e definitivo que nos mostre o caminho do respeito, da tolerância, do diálogo, da responsabilidade, da solidariedade, da preservação da vida e da natureza.

${ }^{347}$ Em duas passagens de seu livro O mínimo que você precisa saber para não ser um idiota, Olavo de Carvalho expressa essa supressão da vocação, pela busca do emprego, e como o brasileiro valoriza títulos e diplomas, mais que o próprio conhecimento. "A realização superior do homem na vocação é então substituída pela mera busca do emprego, visto apenas como meio de subsistência e sem qualquer importância própria no que diz respeito ao conteúdo. A adaptação conformista a um emprego medíocre e sem futuro é considerado o máximo do realismo, a perfeição da maturidade humana. Tudo o mais é depreciado (e por isto mesmo hipervalorizado e ansiosamente desejado) como "diversão"." [...] "Se há uma coisa óbvia na cultura brasileira, é o desprezo pelo conhecimento e a concomitante veneração pelos títulos e diplomas que dão acesso aos bons empregos. Isso é uma constante que vem do tempo do Império e já foi abundantemente documentada na nossa literatura. Nessas condições, campanhas publicitárias que enfatizem a educação como um direito a ser cobrado, e não como uma obrigação a ser cumprida pelo próprio destinatário da campanha, têm um efeito corruptor quase tão grave quanto o do tráfico de drogas. Incitam as pessoas a esperar que o governo lhes dê a ferramenta mágica para subir na vida sem que isto implique, da parte delas, nenhum amor aos estudos, e sim apenas o desejo do diploma." (Olavo de Carvalho. O Mínimo que você precisa saber para não ser um idiota. $5^{\text {a }}$ ed. Rio de Janeiro: Record, 2013.p. 48 e 359). 
professor e outras atividades, que nem de longe cumprem a função de bem preparar o estudante para a vida após o término da universidade. ${ }^{348}$

Outro motivo relaciona-se a seu custo, que comparado a muitos, é mais acessível, o que atrai vários estudantes, que desejam ter formação superior, mesmo sem qualquer vocação jurídica. E isto porque é um curso que não tem laboratórios; sua carga horária é de meio período; o custo do material didático não é elevado.

Mais um motivo, que seria um grande chamariz, refere-se ao fato de que o bacharel em Direito possui uma enorme gama de possibilidades de empregos e carreiras, desde a iniciativa privada, como pública, com acesso a diversos concursos públicos possíveis e imagináveis. ${ }^{349}$

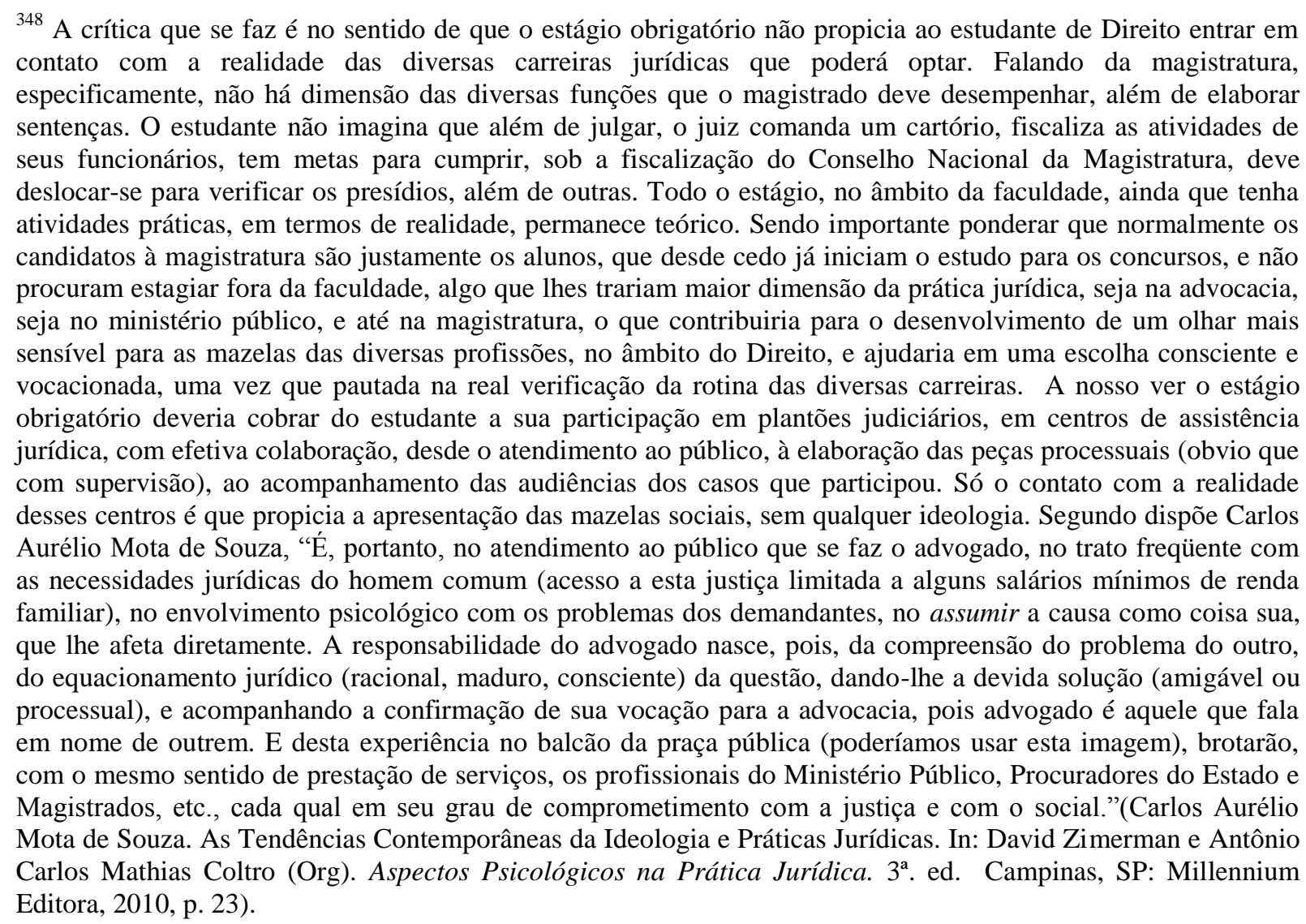

349 "Não perdem de vista, contudo, seus ideais pragmáticos, econômicos, tais como o de fazer carreira. Diante do grande número de advogados que se formam anualmente nas Faculdades de Direito, sobretudo em São Paulo, o campo de trabalho encontra-se atualmente muito competitivo; doutra parte, as administrações públicas, federal, estadual e municipal, têm necessidade crescente de funcionários qualificados no corpo jurídico, e o bacharel em Direito vem atender a estas demandas. Por esta razão pela qual os recém-formados preferem à banca da advocacia, com todas suas vicissitudes iniciais, uma carreira segura e orientativa”. (Carlos Aurélio Mota de Souza. As Escolas de Direito no que Tange ao Preparo Psicológico. In: David Zimerman e Antônio Carlos 
Compartilha-se do entendimento de que a pretensão de escolher a profissão da vida entre os 16 (dezesseis) e 18 (dezoito) anos de idade é realmente complicada ${ }^{350}$, o que pode acarretar a opção por determinados cursos que confiram um maior leque de possibilidade de empregos, e até por isso, acredita-se que o curso de Direito, por todos os motivos expostos, é muito escolhido.

Com isso, não se está a afirmar que a escolha pelo curso de Direito seja pautada somente nessas condições ou, ainda assim, que obrigatoriamente alije o candidato de sua vocação, até porque a universidade desperta paixões, podendo, inclusive, ajudar o aluno a encontrar a sua real vocação. Apenas, pondera-se que o curso de Direito, em razão das facilidades retro mencionadas, acaba atraindo muitas pessoas que não guardam qualquer identificação com o curso, e que muitas vezes farão suas escolhas de carreira muito mais em função dos ganhos que dela advirão, que motivados pelo serviço que gostariam de prestar. ${ }^{351}$

Conhecendo esta realidade, concordamos com Carlos Aurélio Mota de Souza quando diz que: "A Faculdade não pode olvidar que alunos que nela ingressaram, embora se considerem adultos, restam adolescentes em muitos aspectos psicológicos. Portanto, até finalizarem o curso, em muitas facetas necessitam de um amadurecimento, que vem da afirmação psíquica, construída diuturnamente, pois ninguém se forma adulto de uma vez, mas de espaço a espaço. [...] Um adequado Laboratório de Psicologia desempenharia um trabalho

Mathias Coltro (Org). Aspectos Psicológicos na Prática Jurídica. 3. Ed. Campinas, SP: Millennium Editora, 2010, p. 28).

350 "Outro aspecto a ser considerado é o momento em que é feita a opção pela profissão. A maior parte dos estudantes faz essa escolha num instante de intensa turbulência psicológica, que é a adolescência, caracterizada por um período no qual, em curto espaço de tempo, ocorrem mudanças intensas, tanto físicas quanto emocionais. Além disso, a escolha profissional frequentemente ocorre sob a pressão do término do ensino médio e a conseqüente inscrição no exame vestibular, sem que, necessariamente, coincida com o momento em que o jovem está pronto para escolher. Mesmo a maratona do período de cursinho não garante uma opção, apesar das exposições feitas por profissionais de diversas áreas, os quais costumam esclarecer sobre suas áreas de atuação profissional. O que habitualmente ocorre é que o estudante acaba escolhendo uma faculdade e não uma profissão. Finalmente, é comum observar que a escolha pode estar ligada a processos inconscientes, relacionados à tentativa de resolução de conflitos internos que certamente não serão assim sanados. Como exemplo, podemos citar o estudante que opta pela faculdade de Direito, por ter se sentido, na infância e adolescência, socialmente inferiorizado; inconscientemente, acaba buscando tal profissão como forma de resolver o conflito, pois acredita que isso o projetará no plano social." (Carmen Silvia de Oliveira Quadros. O Estudante de Direito. In: David Zimerman e Antônio Carlos Mathias Coltro (Org.). Aspectos Psicológicos na Prática Jurídica. $3^{\mathrm{a}}$. ed. Campinas, SP: Millennium Editora, 2010, p. 227-228).

${ }^{351}$ Em palestra intitulada "A Rebelião da Toga Revisitada", proferida, em 29/08/2013, na APAMAGIS, pelo Desembargador José Renato Nalini, referido palestrante disse ouvir com tristeza o desabafo de muitos juízes que afirmam trabalhar para viver; concluindo que isto significava a perda do sagrado da profissão. 
importantíssimo no despertar e reforçar os instintos vocacionais, encaminhando os vocacionados para a profissão adequada a seu perfil., 352

Partindo, portanto, dessa constatação, interessante seria considerar a possibilidade de os cursos universitários, e para os fins deste trabalho, importa o de Direto, terem este aporte psicológico, que certamente, auxiliaria e muito os alunos a reconhecerem seus talentos, e assim, poderem se direcionar para as profissões, nas quais melhor poderão servir.

Neste desiderato, além da ajuda psicológica, efetivamente prestada por profissionais da saúde, entende-se que os professores universitários detém considerável responsabilidade no despertar vocacional de seus alunos. Nessa medida, devem demonstrar paixão pelo compartilhar de conhecimento; comprometimento com o conteúdo substancial de cada matéria; atuação ética; esforço pela manutenção de um espaço saudável de troca de conhecimentos, alinhado ao respeito pelas diferenças de opiniões; abster-se de reproduzir nos alunos suas ideias e sentimentos pessoais, aproveitando-se de sua condição de formador de opinião; devendo ainda expor sua honestidade intelectual, franqueando aos alunos acesso a posicionamentos contrários aos seus. A academia não pode ser palco de devaneios ideológicos. O professor não tem liberdade para ensinar apenas o que lhe agrada. Deve-se conferir aos estudantes a mais ampla possibilidade de conhecimento. Há que se resgatar o amor pelo debate, pela dialética, pela zetética, acima de qualquer vaidade.

Pois se é verdade que é de exemplo que se aprende. Então, como aprender a ser um profissional ético ${ }^{353}$, tolerante, que consiga se colocar no lugar do outro, se na universidade muito do que ainda se vê é a pura transmissão das ideologias dos professores. ${ }^{354}$

\footnotetext{
352 Carlos Aurélio Mota de Souza. As Escolas de Direito no que Tange ao Preparo Psicológico. In: David Zimerman e Antônio Carlos Mathias Coltro (Org.). Aspectos Psicológicos na Prática Jurídica. $3^{\mathrm{a}}$. ed. Campinas, SP: Millennium Editora, 2010, p. 46.

353 "Nessa ocasião aproveitei o ensejo para sustentar a tese de que a formação ética do ser humano há de ter lugar durante toda a sua vida - desde o dia em que nasce até aquele em que morre, certo como é que o homem dito "moderno", o que acha em via de penetrar os umbrais do século XXI, atravessa a existência sob o signo da "educação permanente", apresentando-se-lhe a morte, até certo ponto, como a última lição que recebe da vida ao se afastar deste mundo de Deus." (Esther Figueiredo Ferraz. A Ética do Juiz. Formação Básica e Vida Familiar. In: José Renato Nalini (Coord.). Uma Nova Ética para o Juiz. São Paulo: RT, 1994, p. 56).

354 “Compete ao educador do Direito orientar e desenvolver em seus alunos o gosto pelo ensino, pela prática das virtudes mais antigas que o Direito protege, e que se expressam objetivamente no estudo e aplicação eficaz dos Direitos do Homem, seja pela sociedade, seja pelo governo organizado [...]. Em suma, os bacharéis serão o que os professores lhes ensinaram, obviamente, assim como os filhos retem o que são seus pais, salvo raras exceções, positivas ou negativas. A linguagem do professor será a linguagem dos bacharéis; a postura do professor será a de
} 


\title{
O repensar do papel do educador já era algo que inquietava o Ministro Sálvio de
}

Figueiredo Teixeira, que com suas sábias palavras, há tempos escreveu:

\begin{abstract}
Há, em suma, de se repensar o papel do educador. A transmissão dele reclamada já não se centra no repositório do conhecimento técnico, senão na experiência de vida. O educador há de ser, sobretudo, um estimulador, para que o estudante saiba não só se valer do conteúdo de informações postas à sua disposição, mas também selecionar dentre elas as mais úteis. [...]. Muito mais importante, ainda, será a capacidade de o educador transmitir emoção e caráter. Essa, a sua missão primeira e mais relevante, quando se sabe que a estrutura do nosso conhecimento clássico está alicerçada na razão. Nós, os educadores, em regra, somos formados e continuamos fiéis aos esquemas do racionalismo. Precisamos descobrir, agora, a "epistemologia da existência", o existir como condição para ver o mundo, que inclui, em primeiro lugar, a emoção, a cultura do coração. Porque se a razão reduz a força de descobrir, é a emoção que nos leva a ser originais. O cultivo da emoção é um trabalho conjunto dos estudantes e dos mestres. $^{355}$
\end{abstract}

\section{Prosseguindo em seu discurso, o Ministro citou José Renato Nalini, como exemplo de educador, que teria professado o que se exige, sob a ótica contemporânea, do educador e do universitário brasileiros.}

Daí as colocações hauridas na lucidez de José Renato Nalini, educador dos mais talentosos, sob a ótica da contemporaneidade, ao dizer sobre o que se exige do educador e do universitário brasileiros. O que se reclama do primeiro? Paixão pelo processo educacional, pois não se consegue fazer entender aquele que encara a missão de ensinar como algo burocrático, despido de entusiasmo, transmissão formal de algumas verdades estabelecidas, desempenho de emprego ou mera forma de subsistência. Renovação permanente, dado que a atualização é a regra de ouro para o educador, que precisa manter acesa e com a mesma intensidade a chama de educar. [...] Consciência de forja, quando se sabe que o educador não é intelectual socialmente descomprometido, mas à sua responsabilidade é confiado o mais valioso capital brasileiro: o futuro da juventude. [...] Caráter é o espelho da grandeza do homem. Integra um sistema de valores que agrega a lealdade, o compromisso, a ajuda mútua, o companheirismo, a confiança, a inteireza de propósitos [...] É

seus alunos, amanhã. Sempre haverá um ou outro professor marcando definitivamente a personalidade dos seus discípulos. A expectativa da Educação dos Bacharéis é a de que atinjam uma visão o mais universal possível do Direito (para distinguirem os diversos ramos em que se dividem), e a de que cada um desses, com suas várias disciplinas, tenha sido compreendido também em sua totalidade, e não com visões parciais, que incluem visões errôneas da respectiva ciência." (Carlos Aurélio Mota de Souza. As Escolas de Direito no que Tange ao Preparo Psicológico. In: David Zimerman e Antônio Carlos Mathias Coltro (Org.). Aspectos Psicológicos na Prática Jurídica. $3^{\text {a }}$. ed. Campinas, SP: Millennium Editora, 2010, p. 36 e 45).

355 Sálvio de Figueiredo Teixeira. Ensaios. A Universidade: Compromisso com a excelência e instrumento de transformação In: Ministro Sálvio de Figueiredo Teixeira: Homenagem. Brasília: Superior Tribunal de Justiça, 2007. 410 p. (Coletânea de Julgados e Momentos Jurídicos dos Magistrados no TFR e STJ; 51), p. 334. 
reforçando o caráter que se prepara a Nação para o enfrentamento da globalização. [...]. O Brasil tem condições de ensinar ao mundo que a diferença torna mais atraente o convívio e que a miscigenação é uma receita deliciosa. A mocidade, desperta para uma participação ativa na resolução dos problemas brasileiros, não encontrará óbices ao exercício de uma criatividade conseqüente. Todos, irmanados, encontrarão o justo equilíbrio entre a competitividade e a partilha, entre a auto-realização e o estímulo ao crescimento alheio, entre o desenvolvimento sustentado e a preservação do patrimônio ambiental. E o que se espera do universitário? Consciência universitária, uma vez que a parcela dos privilegiados que alcança os bancos da Universidade tem um compromisso com aqueles que ficaram à beira do caminho. [...] Participação, na medida em que a Pátria é uma construção diuturna. [...] Cobrança, porque o envolvimento em um projeto nacional legitima o estudante a cobrar de seus dirigentes uma postura compatível com as exigências da nacionalidade. ${ }^{356}$

É, portanto, a partir do resgate por parte dos professores e dos alunos do verdadeiro amor pelo compartilhar do conhecimento, por ver o outro brilhar, que se poderá viabilizar a tão sonhada educação do caráter, mencionada por Sálvio de Figueiredo Teixeira e José Renato Nalini.

E será pensando nela que a faculdade deverá se humanizar ${ }^{357}$ ainda mais, priorizando as matérias humanísticas, que agreguem aos estudantes o senso de responsabilidade ligado à distribuição e luta pela Justiça. O gosto pela filosofia, que é a mãe de todas as disciplinas, pois desperta o amor pelo saber, tanto externo quanto interno.

Nessa linha, a crítica de José Renato Nalini faz todo sentido:

A escola de Direito não ensina a pensar. Dispensa à Filosofia tratamento idêntico ao das demais disciplinas. Um semestre ou dois de aulas prelecionais. O mesmo faz com a Ética, a matéria-prima de que se ressente em primeiro lugar este Brasil continental. Ambas deveriam ser preocupação permanente e objeto de uma visão transversal,

\footnotetext{
${ }^{356}$ Sálvio de Figueiredo Teixeira. Ensaios. A Universidade: Compromisso com a excelência e instrumento de transformação In: Ministro Sálvio de Figueiredo Teixeira: Homenagem. Brasília: Superior Tribunal de Justiça, 2007. 410 p. (Coletânea de Julgados e Momentos Jurídicos dos Magistrados no TFR e STJ; 51 ), p. 335-336.

357 "Humanizar o ensino jurídico é, mutatis mutandi, transpor para o currículo das Faculdades a figura da pessoa humana com toda a dignidade que a caracteriza e que a Constituição lhe confere e garante. Digamos que é preciso constitucionalizar os currículos escolares, sobrelevando, nas diferentes disciplinas, a pessoa humana como destinatária última de todos os ensinamentos. A pedagogia do homem: muitos somos criticados, e certamente o seremos, por sustentar um pensamento utópico ou pelo menos estarmos propondo o óbvio no ensino jurídico.[...] Porém, a ênfase se coloca na pedagogia, na forma de introduzir os valores humanos, desvendando-os do interior dos conteúdos programáticos, fazendo ressaltar em toda linha qualquer item que revela a pessoa humana, sua valoração, sua dignidade." (Carlos Aurélio Mota de Souza. As Tendências Contemporâneas da Ideologia e Práticas Jurídicas. In: David Zimerman e Antônio Carlos Mathias Coltro (Org.). Aspectos Psicológicos na Prática Jurídica. $3^{\text {a }}$. ed. Campinas, SP: Millennium Editora, 2010, p. 13).
} 
presentes em todas as disciplinas e na estratégia de aprendizado explorada pela Universidade. ${ }^{358}$

Será nesse espaço que o universitário também poderá aprender (ou relembrar) a respeitar as diversidades, conviver com as diferenças e, desde cedo, exercitar o colocar-se no lugar do outro, condoer-se pela dor do outro, importar-se, efetivamente, com o outro, de forma a trilhar o seu futuro, com o compromisso de fazer melhor aquilo que já se faz bem, de superar limites, de envolver-se, de corpo e alma, entregando-se a seu propósito de vida.

Dentro desse novo paradigma, muito bem-vindas serão as disciplinas práticas, que estabeleçam dinâmicas, nas quais os estudantes experimentem, de fato, situações reais de conflitos, podendo treinar a alteridade. ${ }^{359}$

E, em busca da alteridade, e de diferentes formas de trabalhar conteúdos pedagógicos em sala de aula, relevante mencionar a experiência de Ruy Cezar do Espírito Santo, que como docente de Pedagogia, na Pontifícia Universidade Católica de São Paulo, efetivamente, introduziu em sua sala de aula, uma dinâmica diferenciada, buscando com a interdisciplinaridade despertar no aluno o encontro consigo mesmo.

Com efeito, referido autor, por acreditar como o filósofo Sócrates, que somente o autoconhecimento libera de falsas concepções, para o alcance da verdadeira sabedoria, iniciou um trabalho na PUC, que objetivou o desvendar do potencial humano, para uma visão integradora de si mesmo e do universo à sua volta, com fim de escapar da visão estritamente racional, que rege os bancos universitários.

Sua proposta foi realmente levar para a sala de aula a realização de vivências, trabalhando os conteúdos, dividindo a classe em grupos, sendo que o tema estudado seria

\footnotetext{
358 José Renato Nalini. A Responsabilidade do Juiz na Condução Racional do Processo. Revista da Escola Nacional da Magistratura, Brasília, Escola Nacional da Magistratura, ano VII, n 6, 2012, p. 460.

359 "De acordo com a Psicologia Analítica na teoria da conciliação dos opostos, o problema das diferenças não se resolve na igualdade (quer seja ela religiosa, étnica ou política), mas na aceitação da riqueza das diferenças, o que se dá na dominância do arquétipo da alteridade.” (Lídia Reis de Almeida Prado. O Juiz e a Emoção: aspectos da lógica da decisão judicial. Campinas: Millennium Editora, 2003, p. 104).
} 
enfocado em diferentes perspectivas. Um grupo deveria abordar o tema com enfoque no plano físico; outro, sob o emocional; o terceiro, sob o racional; e o último, sob o plano espiritual.

Ao contrário do normalmente exigido nos cursos de Direito, cuja escrita é premente, na experiência de Ruy Cezar do Espírito Santo, o objetivo era outro. Então, a primeira instrução que cada grupo recebia era que a apresentação do trabalho deveria obedecer aos critérios de comunicações visuais, tácteis, corporais e outros, com exclusão de leitura de qualquer texto explicativo. A única parte escrita seria um texto final de conclusão, para entregar à classe após a apresentação do trabalho.

Nas palavras do próprio autor:

Um dos objetivos de tal proposta é o educando perceber que qualquer temática escolhida, sempre permitirá quatro possíveis leituras ao nível de entendimento e pesquisa. Ou seja, a "realidade" não se resume ao plano físico, ou ao emocional, ou ainda ao racional ou finalmente ao espiritual. Há uma necessidade do educando perceber a integração e presença permanente dessas quatro realidades, em si mesmo e a seu redor. Por que isso? A razão está em permitir aos alunos um Caminho, que os leve a "escapar", da pura racionalidade habitual, nos seminários comumente apresentados na Universidade. [...] Ocorre, todavia, que a razão maior dessa forma de apresentação, e seu objetivo maior, é para que ocorra na leitura do trabalho final, ou seja na apresentação do seminário, uma transdisciplinaridade da temática, a partir das quatro vertentes dadas nos planos físico, emocional, racional e espiritual. Sim, ao ser eliminada a visão estritamente racional, da elaboração de um texto para ser lido, todos os aspectos se farão presentes, independentemente, do ponto de partida da pesquisa. É nesse instante que a transdisciplinaridade se faz presente na percepção dos educandos! Sim, o corpo físico surge nas dramatizações necessárias, para "dizer" da pesquisa feita. O corpo emocional surge nos gestos, nas falas, nas expressões [...] O corpo racional obviamente se faz presente na montagem toda do procedimento. Finalmente o corpo espiritual aparece na beleza, na alegria e de forma especial na conexão provocada com a classe, que tem sua raiz numa vivência amorosa, de vínculo com a classe. ${ }^{360}$

Através desse método de Ruy Cezar do Espírito Santo, o aluno amplia a visão sobre a completude do tema, antes restrita apenas a textos escritos. Por meio dessas experiências, os estudantes poderão expandir os instrumentos, que normalmente utilizam para trabalhar, e através da criatividade, expor à classe tudo o que foi pesquisado, sem o apego ao já conhecido formato escrito. Então, há dramatizações, cenários, danças, desenhos, enfim, há permissão

360 Ruy Cezar do Espírito Santo. Transdisciplinaridade e autoconhecimento. Disponível em: 〈http://cetrans.com.br/artigos/Ruy_Cezar_do_Espirito_Santo.pdf>. Acesso em: 27 nov. 2013. 
para cruzar a zona de conforto (ou desconforto); ir além do esperado, do formato padronizado e arraigado nas universidades, e em especial, nos cursos de Direito.

Esse tipo de vivência é algo de uma riqueza ímpar, para auxiliar o estudante a exercer a alteridade. Isso porque o trabalho com grupos impõe diversos desafios, seja pela divisão inicial de tarefas, seja por lidar com as diferentes opiniões, pontos de vistas, realidades e temperamentos. Se o grupo for completamente aleatório então, melhor ainda, porque também haverá o desafio do novo para os alunos, já acostumados a reunirem-se sempre com seus pares.

Nessas oportunidades os estudantes poderão exercitar a escuta ativa, a composição, a mediação, a sua colocação; tendo possibilidade de sentir, de fato, todos os problemas de comunicação que existem nos diversos relacionamentos.

Enfim, tira-se desse exemplo de vivência que a faculdade de Direito poderia abrir-se mais para novos horizontes, deixando-se permear pela interdisciplinaridade ${ }^{361}$, algo que propiciaria a seus alunos maior bagagem para o enfrentamento da vida, na medida em que tais experiências, inevitavelmente, ampliam a consciência interior, e remetem os estudantes para o conhecimento de si mesmo.

Em termos de dinâmicas interdisciplinares, poderia pensar em muitas outras, como por exemplo, as oficinas de "Clown" ou de "Palhaço", que tratam de jogos de improviso, trabalhando com a frustração, o fracasso, situações inusitadas, e sempre com humor. Rir da própria desgraça, rir do outro, igualar-se pelo fracasso ou pela vitória. Tudo isso ajuda a levar a vida com mais leveza e desprendimento, contando com a possibilidade do erro. Incrementa a necessária maturidade emocional indispensável a todo ser humano que pretenda lidar com gente. No entanto, para fins deste trabalho, são apenas colocações do que se entende urgente alterar e acrescentar às grades curriculares dos cursos universitários e, em evidência, o jurídico.

\footnotetext{
361 “É indispensável que os docentes se esforcem por adquirir uma visão multidisciplinária e uma formação metodológica hábil ao tratamento e ensino de qualquer ramo do Direito. Que entendam a importância de discutir com os estudantes com prioridade sobre a reflexão dos conteúdos específicos de cada disciplina, as características e caminhos do próprio processo de aprendizagem. Paralelamente, que comecem a preocupar-se mais com a formação da personalidade do aluno do que com o cumprimento rigoroso de um programa." (Luiz Alberto Warat e Rosa Maria Cardoso da Cunha. Técnicas e Conteúdos no Ensino do Direito. In: Luiz Alberto Warat e Rosa Maria Cardoso da Cunha. Ensino e Saber Jurídico. Rio de Janeiro: Eldorado Tijuca, 1977, p. 64).
} 
Além de todo arcabouço técnico jurídico que o aluno terá que aprender e, por isso, não há como afastar, por completo, as matérias teóricas, para a educação do caráter, no entanto, é preciso algo a mais.

É preciso que ele saiba da sua responsabilidade como estudante. Como dito por José Renato Nalini, há contas a prestar, por ter conseguido chegar ao ápice, enquanto muitos ficaram à beira do caminho. ${ }^{362}$

Sempre será função do educador ${ }^{363}$ auxiliar seus alunos a assumir responsabilidade, a procurar compreender o caráter ilícito de seus atos, a não relevar condutas incompatíveis com a condição de estudantes de Direito. ${ }^{364}$ Desde cedo, ainda nos bancos universitários, é importante que os alunos possam exercitar a autorreflexão ${ }^{365}$, e julgarem-se a si mesmos. ${ }^{366}$

\footnotetext{
${ }^{362}$ Isso se aplica a qualquer faculdade, seja privada ou pública. Na segunda, a responsabilidade é ainda maior, na medida em que o custo é arcado por todos os contribuintes, inclusive aqueles que, quem sabe, jamais poderão ter o privilégio de nessas universidades pisar. Há muito a devolver à sociedade e o mínimo que o estudante que galgou essa privilegiada possibilidade deve ter é dedicação e afinco aos estudos, aproveitando ao máximo a oportunidade que teve.

363 "“...] o professor representa o presente, que tem por função unir passado e futuro. O presente é o único momento que conta, e a cada instante, por tudo o que vivemos, fazemos ou ensinamos, estaremos comprometendo o passado e o futuro, pois é dessa forma que se cumpre a parte de eternidade do homem, a perpetuação de sua memória. Proferida, portanto, com adequada psicologia educativa, a palavra do mestre deve despertar a consciência cívica do acadêmico para o exercício de uma autêntica cidadania." (Carlos Aurélio Mota de Souza. As Escolas de Direito no que Tange ao Preparo Psicológico. In: David Zimerman e Antônio Carlos Mathias Coltro (Org.). Aspectos Psicológicos na Prática Jurídica. $3^{\mathrm{a}}$. ed. Campinas, SP: Millennium Editora, 2010, p. 35).

${ }^{364}$ É inadmissível que um estudante de Direito assine a lista de frequência em nome de outro. Tal fato já seria de repúdio a qualquer universitário, mas aos estudantes de Direito, revela-se inaceitável, na medida em que hoje estudantes, atuam como falsários, amanhã como promotores e juízes, processam e condenam os outros por falsidade ideológica. Deve-se, desde o início da faculdade, ponderar a ética e a moral daqueles atos que são feitos sem testemunhas. Aqueles em que basta o nosso juízo moral. Nas palavras de Olavo de Carvalho, "Estou persuadido de que as vivências desse tipo - os atos sem testemunha, como costumo chamá-los - são a única base possível sobre a qual um homem pode desenvolver uma consciência moral autêntica, rigorosa e autônoma. Só aquele que, na solidão, sabe ser rigoroso e justo consigo mesmo - e contra si mesmo - é capaz de julgar os outros com justiça, em vez de se deixar levar pelos gritos da multidão, pelos estereótipos da propaganda, pelo interesse próprio disfarçado em belos pretextos morais."(Olavo de Carvalho. O Mínimo que você precisa saber para não ser um idiota. $5^{\text {a }}$ ed., Rio de Janeiro: Record, 2013, p. 41).
}

365 "Ora, nem todos os seres humanos foram brindados pela Providência com a percepção espontânea e o julgamento certeiro de seus pecados. Sem esses dons, o anseio de justiça se perverte em inculpação projetiva dos outros e em "racionalização" (no sentido psicanalítico do termo). Quem não os recebeu de nascença tem de adquiri-los pela educação. A educação moral, pois, consiste menos em dar a decorar listas do certo e do errado do que em criar um ambiente moral propício ao autoexame, à seriedade interior, à responsabilidade de cada um saber o que fez quando não havia alguém olhando." (Olavo de Carvalho. O Mínimo que você precisa saber para não ser um idiota. $5^{\text {a }}$ ed., Rio de Janeiro: Record, 2013, p. 42). 
É necessário ainda que ele volte o seu olhar para além dos portões da faculdade, e tenha interesse em se envolver com os diversos projetos da sociedade, que certamente o ajudarão a confirmar ou não sua vocação. Só mediante a experiência é que se pode acessar a certeza daquilo que se veio fazer ao mundo. Somente vivenciando as antagônicas realidades de vida, de pleitos, de histórias, é que se desenvolve sensibilidade para lidar com gente. ${ }^{367}$

\footnotetext{
${ }^{366}$ Em passagem do clássico o Pequeno Príncipe, em que o principezinho visita o planeta habitado por apenas um Rei, que o convida a ser seu Ministro da Justiça, ele aprende uma grande lição ao questionar ao Rei quem ele julgaria, se não havia mais ninguém no planeta, quando o Rei lhe diz: "Tu julgarás a ti mesmo - respondeu-lhe o rei. - É o mais difícil. É bem mais difícil julgar a si mesmo que julgar os outros. Se consegues fazer um bom julgamento de ti, és um verdadeiro sábio." (Antoine de Saint-Exupéry. O pequeno príncipe: com aquarelas do autor. Tradução de Dom Marcos Barbosa. 48 ed., Rio de Janeiro: Agir, 2009 p. 39).

${ }^{367}$ David Zimerman, traçando um paralelo entre as profissões de analista e juízes, dispõe sobre os atributos mínimos, que seriam indispensáveis à execução de ambas as funções. A seguir, faremos um resumo desses atributos elencados pelo autor, mas desde já ressaltamos que estas imprescindíveis condições não se aprendem no exercício da função, devendo, quando não portadas como características inatas, ser aprendidas, ainda, nos bancos universitários. Daí também a urgência da faculdade dar esta condição ao universitário. Bem, de forma, resumida, os atributos seriam: a) seriedade, o que significa fazer o melhor possível para terem êxito em sua função; b) empatia, que seria a capacidade de se colocar no lugar do outro, de sentir o seu sofrimento; c) intuição, que não tendo qualquer relação a nada de transcendental, seria a capacidade de olhar para dentro, captando informações, além dos órgãos dos sentidos e do pensamento racional; d) capacidade de ser continente, que significa a condição de conter dentro de si toda carga de necessidades, demandas e angústias que está sendo projetada nele, sem a devolução imediata; e) visão multifocal, que seria a visão holística, ou seja, uma forma de perceber nos fatos ou nas pessoas que o todo é inseparável das partes constituintes, o que afastaria o risco, nada incomum, de se adotar um único ponto de vista, com a convicção absoluta de que se está sempre certo, ficando surdo e cego para diferentes pontos de vista, algo que trás inúmeros prejuízos às partes envolvidas, pois tal radicalismo está fundamentado em pré-conceitos; f) saber comunicar, pois segundo o autor, o maior mal da humanidade seria o problema dos mal-entendidos; e conhecedores dos diversos problemas com a transmissão e recepção das mensagens, os analistas e juízes, deveriam estar atentos às possíveis modalidades de transtornos na forma e intenção de comunicar que procedem das pessoas que eles atendem em suas atividades, de modo a não se deixar envolver em mal-entendidos, e fazerem sempre autorreflexão, naqueles casos em que não evoluem bem, para que possam assumir a responsabilidade pelas possíveis dificuldades nas suas formas de transmitir o conteúdo do que está sendo dito, ou nas formas como recepcionam aquilo que os outros estão dizendo; g) o risco do narcisismo excessivo, que, segundo o autor, a própria natureza da posição dos analistas e magistrados facilita o surgimento da crença da onipotência, uma vez que há sempre uma corte de bajuladores, que é especialista em inflar o ego de um juiz ou terapeuta pavão. Além disso, acrescenta outro inconveniente que seria o fato de uma pessoa excessivamente narcisista se tornar uma pessoa contraditória, na medida em que trata de uma forma os seus bajuladores, e de outra, totalmente hostil, os que não aderem à corrente da bajulação; $h$ ) ser verdadeiro, sendo ideal que haja consistência e coerência naquilo que eles sentem, dizem, fazem e o que, de fato, são. (David Zimerman. Uma Aproximação Entre o Perfil da Figura do Juiz de Direito e a do Psicanalista. In: David Zimerman e Antônio Carlos Mathias Coltro (Org.). Aspectos Psicológicos na Prática Jurídica. $3^{\mathrm{a}}$ ed. Campinas, SP: Millennium Editora, 2010, p. 603-610).
} 
A universidade tem, portanto, importância ímpar no despertar do sentimento de colaboração, de participação, de integração, de comunicação, de visão multifocal, de modo que o olhar além do próprio umbigo seja, desde cedo, um objetivo a ser alcançado. ${ }^{368}$

Nesse continuo aprendizado focado no olhar além do umbigo, que perpassa a consideração pelas diferenças, pouco a pouco, o estudante vai desenvolvendo a empatia, a condição de se colocar no lugar do outro, de sentir como seria estar na situação do outro, aproximando de si tudo o que antes era relativo, tratando como seu aquilo que é problema do outro.

Assim, os universitários poderão escolher suas carreiras, encorajados pelo pulsar de seus corações, preocupando-se mais com a realização espiritual ${ }^{369}$ que com o sucesso profissional, pautado em valores externos. E dessa forma, poderão ser canais, independentemente da carreira escolhida, de valores humanos.

Bem, mas enquanto não se alcança esta tão almejada cultura de paz e prosperidade, que tem origem na confiança de que cada ser humano detém um presente, um talento para doar ao mundo, e que há espaço para todos brilhar no palco da Terra; algumas medidas paliativas devem ser tomadas, conforme exposto acima, pois ainda há muitas pessoas que focalizam suas carreiras no comodismo, na segurança, na estabilidade financeira, no sucesso, na busca de poder e etc.

A magistratura, por acaso, é uma carreira que abriga essas e tantas outras qualidades, o que, por óbvio, atrai muitos que buscam esses objetivos.

E como, infelizmente, ainda hoje, mesmo com todos os avanços dos concursos públicos, com acréscimo de matérias humanísticas nas avaliações, ainda tem grande peso a memorização de leis, doutrina e jurisprudência ${ }^{370}$, pois não é permitida sua consulta ${ }^{371}$, nem

\footnotetext{
${ }^{368}$ O Brasil tem extensão de Continente, abrigando diversas e antagônicas realidades, inimagináveis, a quem se encontra em um polo ou em outro. Interessar-se por conhecer as diferentes realidades, e até participar de forma efetiva delas, ajuda o desenvolvimento da continência, a respeitar as diferenças, a aceitar e conviver com o desigual. O olhar além do umbigo é algo plenamente alcançável.

${ }^{369}$ Como espiritual, entenda-se o conceito genérico de espiritualidade, que quer dizer verdade. Então, seria a realização do projeto pessoal e único de cada indivíduo, do seu propósito de vida.

370 "Quando chamada ao debate, a cultura manualística que ganha vulto impressionante em meio à doutrina pátria aparece para confirmar suas premissas autistas destinadas à mera captação mnemônica dos futuros "operadores" do Direito, vazia de considerações de maior profundidade: "A sentença é uma manifestação lógica e formal", repete-se à exaustão, onde se opera "aplicando-se a lei ao caso concreto". (Gabriel Antinolfi Divan. Decisão
} 
sempre os que têm sucesso são os realmente vocacionados, preparados emocionalmente, competentes, para exercer tão árdua função.

Como bem ponderam José Renato Nalini e Lídia Reis de Almeida Prado, é mais que chegada a hora de buscar o ser humano que se encarregará de julgar os demais, sendo que nessa busca, o conhecimento jurídico não deve ser o critério norteador.

Até há pouco os tribunais se preocupavam com a escolha dos mais cultos. Assim considerados os que provassem capacidade de amealhar um acervo imenso de informações pertinentes e de reproduzi-las quando inquiridos por uma banca examinadora. Agora é chegado o momento de procurar primeiro o ser humano e depois o conhecimento jurídico. ${ }^{372}$

O juiz desempenha uma função que atinge aspectos essenciais da vida individual e social. Entretanto, como qualquer ser humano, não está imune às influências do inconsciente. Por isso, não é concebível que, num tempo em que não mais se discute a importância dessa instância do psiquismo, o Judiciário persista na adoção de critérios apenas formais na seleção, preparação e aperfeiçoamento daqueles que vão decidir o destino dos indivíduos e dos grupos sociais. ${ }^{373}$

Judicial nos Crimes Sexuais: o julgador e o réu interior. Porto Alegre: Livraria do Advogado Editora, 2010, p. $65)$.

${ }^{371}$ Ricardo Pippi Schmidt, Juiz de Direito no Rio Grande do Sul e integrante da Ajuris deste Estado, propondo alterar a Resolução 75 do Conselho Nacional de Justiça, de 12/05/2009, que dispõe sobre os concursos públicos para o ingresso na carreira da magistratura em todos os ramos do Poder Judiciário nacional, no que tange à primeira fase do concurso, assim dispõe: "Ao vedar a consulta à legislação durante a prova objetiva, a Resolução 75 do CNJ perdeu grande oportunidade de inovar, afastando-se de um modelo ultrapassado que segue impondo aos candidatos inócua memorização do texto legal na primeira prova do concurso, exigência totalmente dissociada do contexto da sociedade da informação, que permite a todos, em segundos, acesso a todo o tipo de conhecimento. Ora, hoje qualquer juiz, em qualquer lugar deste país, do Oiapoque ao Chuí, tem acesso à Internet e aos bancos de dados do Congresso Nacional e dos tribunais, onde pode em instantes consultar a legislação recém-aprovada, as súmulas e jurisprudência mais atualizada. Pergunta-se, então: quem de nós ainda memoriza lei? Qual o objetivo de impedir que os candidatos possam ter acesso ao menos ao texto da lei ao realizar a prova objetiva? Não estaremos aqui apenas reproduzindo práticas do passado, sem refletir sobre a sua adequação aos novos tempos? A primeira proposta diz, pois, com a mudança no regramento do concurso para a magistratura, com estímulo à seleção dos mais aptos, que não são necessariamente os de maior capacidade de memorização, o que exige a alteração do art. 34, II, da Resolução 75 do CNJ, de modo a permitir aos candidatos ter acesso aos textos de lei não comentados." (Ricardo Pippi Schmidt. Administração Judiciária Seleção e Formação de Juízes - Propostas de Alterações na Resolução $n^{\circ} 75$ do Conselho Nacional de Justiça. Revista da Escola Nacional da Magistratura. Brasília, Escola Nacional da Magistratura, ano VII, n 6, nov., 2012, p. 22-23).

372 José Renato Nalini. A Responsabilidade do Juiz na Condução Racional do Processo. Revista da Escola Nacional da Magistratura, Brasília, Escola Nacional da Magistratura, ano VII, n 6, nov., 2012, p. 464.

373 Lídia Reis de Almeida Prado. O Juiz e a Emoção: aspectos da lógica da decisão judicial. Campinas: Millennium Editora, 2003, p. 104. 
Por mais que o sistema de recrutamento dos juízes tenha evoluído, e isto é inegável, haja vista a inclusão, nos concursos públicos, de disciplinas interdisciplinares, como a filosofia e psicologia, ainda assim seu formato não propicia a escolha dos vocacionados.

A crítica, aliás, é feita pelos próprios magistrados, na esteira das tantas menções que foram feitas ao longo desse trabalho. Podendo-se dizer que em São Paulo, o maior expoente é o atual Presidente do Tribunal de Justiça de São Paulo, o Desembargador José Renato Nalini $^{374}$.

Sabe-se que os concursos públicos, com as diversas etapas probatórias, pelo caráter democrático que possuem, propiciando que qualquer bacharel em Direito a eles acorram, são uma realidade impensável de mudança, porque garantem a devida segurança e isenção de que o candidato exitoso, efetivamente, galgou todos os degraus, que o consagraram magistrado.

Também se conhece a realidade de que através dos concursos públicos, houve diversificação da origem dos magistrados, do ponto de vista social, econômico e cultural, assim como propiciou o ingresso de mais mulheres na magistratura. ${ }^{375}$

Compreendemos essa realidade, não questionamos o concurso público em si, porém, não concordamos que somente aqueles que amealharam conhecimento técnico suficiente, para satisfazer as várias fases dos concursos, sejam os realmente intencionados, comprometidos e, devotados à função que deverão exercer.

Muito se perde em material humano, pelo fato de os concursos públicos serem tão rigorosos, não admitindo sequer consulta à legislação, doutrina e jurisprudência, em sua primeira fase. Aliás, esta exigência, hoje em dia, não se coaduna com a realidade, em que patente o rápido e certeiro acesso a todo tipo de fonte de conhecimento.

Ainda que haja, na sequência, etapas no concurso, com a inclusão de matérias interdisciplinares, visando aferir o conhecimento do candidato, em disciplinas essenciais para

\footnotetext{
374 “Os valores da nova era estão distantes da memorização, pois a sociedade mediática permite a localização, pelas infovias, de um universo de informações atualizadas. Passam mais pela flexibilidade, pela polivalência, pela criatividade, pela intuição. Atributos que nunca estiveram na cogitação dos recrutadores de juízes." (José Renato Nalini. O Juiz e o Acesso à Justiça. 2. Ed. São Paulo: RT, 2000, p. 154).

375 Eugênio Facchini Neto. E o Juiz não é só de Direito...' (ou 'a Função Jurisdicional e a Subjetividade’). In: David Zimerman e Antônio Carlos Mathias Coltro (Org.). Aspectos Psicológicos na Prática Jurídica. $3^{\mathrm{a}}$ ed. Campinas, SP: Millennium Editora, 2010, p. 269.
} 
o incremento da maturidade emocional, todo o concurso é motivado para fora, ou seja, para balizar o conhecimento externo e objetivo do aspirante.

Como advertido por José Renato Nalini ${ }^{376}$, não há preocupação em buscar o ser que habita os candidatos a julgadores. Não existe interesse por conhecer suas angústias, dúvidas existenciais, e de verdade, saber o que o motivou a participar desse certame.

Uma sugestão, na linha do quanto já foi desenvolvido nesse trabalho, seria também nesta oportunidade incorporar as dinâmicas, mencionadas acima. Levar para dentro do concurso a interdisciplinaridade, mas não como forma de aferição de conhecimento, nos moldes já existentes; mas sim como inclusão do candidato nessas vivências.

Podia-se pensar numa fase do concurso, onde seria necessário o aspirante passar por elas, que muito bem poderiam ser oficinas de "Clown ou Palhaço"; dramatizações, com situações reais de conflitos, nos quais eles teriam que antecipar seus julgamentos; meditações ativas, com respiração, dinâmicas corporais, rodas de conversas; tudo a propiciar um espaço para que a interioridade desses candidatos se manifeste.

Seria muito importante para considerar a inteligência emocional daqueles que pretendem julgar os outros. Isso porque, nesses tipos de dinâmicas, é impossível o exercício do autocontrole. A rigidez é quebrada e, cedo ou tarde, o candidato irá se revelar ${ }^{377}$.

Não se desconhece que o candidato, à medida que avança nas etapas concursais, passa por avaliação psicológica, para verificação de traços de sua personalidade. No entanto, estas avaliações restringem-se à aplicação de testes, não havendo escuta psicoterapeuta individual e nem grupal. Não há nessa oportunidade possibilidade de adentrar o mundo interior do interessado no concurso.

\footnotetext{
376 “[...] não há preocupação equivalente em conhecera personalidade do futuro juiz. Seus temores e angústias, seus traumas, seus preconceitos, mas também seus anseios, aspirações, sonhos e ilusões." (Prefácio de José Renato Nalini in Lídia Reis de Almeida Prado. O Juiz e a Emoção: aspectos da lógica da decisão judicial. Campinas: Millennium Editora, 2003, p. X).

377 “Na visão de Freud, as pessoas não são o que elas pensam que são ou o que elas aparentam ser. Os mortais não conseguem se esconder o tempo todo, guardar seus segredos. E, ainda que suas bocas estejam fechadas, eles se traem com as pontas de seus dedos, com o movimento de seus olhos. A traição força a passagem através da expressão verbal e não verbal, corporal, do silêncio." (Paulina Cymrot. Nossas Lembranças: Guardam Intimidade com as Ficções e São Sempre Fontes Suspeitas? In: David Zimerman e Antônio Carlos Mathias Coltro (Org.). Aspectos Psicológicos na Prática Jurídica. 3a. ed. Campinas, SP: Millennium Editora, 2010, p, 339). A respeito da linguagem emocional e corporal, vide também Paul Ekman. A linguagem das emoções. Tradução de Carlos Szlak. São Paulo: Lua de Papel, 2011.
} 
Hoje, mais que nunca, os magistrados estão sendo convidados a promover uma verdadeira reforma do Judiciário. E essa reforma somente acontecerá quando, em um primeiro nível, houver consciência do material humano que está sendo recrutado ${ }^{378}$.

Enquanto a cegueira para a necessária compreensão da falibilidade do homem permanecer, e se esperar do julgador somente o conhecimento de um verdadeiro arcabouço técnico-jurídico, não haverá possibilidade de alteração do paradigma já instalado.

Os concursos devem ter condições de recrutar aqueles que, mesmo com todas as imperfeições inerentes a todo ser humano, tenham melhor desenvolvidas certas qualidades imprescindíveis à função, quais sejam: humildade ${ }^{379}$, temperança, tolerância, ética, empatia, dentre outras; além de possuírem inesgotável vontade de melhorar sempre, de todos os dias aprender, e de, enfim, se autoconhecer ${ }^{380}$.

Deve, ainda, poder reconhecer aqueles que possuem equilibradas as características masculinas e femininas, em uma mesma pessoa, de modo que possam integrar o pensamento e a técnica com o sentimento. ${ }^{381}$

\footnotetext{
378 "Se os concursos se preocupassem mais com o ser humano interessado em ingressar na Magistratura e menos com a sua possibilidade de decorar informações, teria início a verdadeira Reforma do Judiciário." (Prefácio de José Renato Nalini in Lídia Reis de Almeida Prado. O Juiz e a Emoção: aspectos da lógica da decisão judicial. Campinas: Millennium Editora, 2003, p. XI).
}

379 "O Juiz que não reverencia a humildade, acaba por afastar-se de outras qualidades que são, também, necessárias a si, primeiro como pessoa e, em seguida, de conseqüência, como juiz. [...] Aquele a quem falta humildade não pode ter espírito isento de paixões, porquanto o fato de superestimar-se o levará a defender suas idéias mais pela insistência de não ser dado como suscetível de modificá-las, do que por outra razão. E a quem falta a isenção de ânimo, faltará a serenidade, já que a última é aferida a partir da primeira.” (Antonio Carlos Mathias Coltro. Juiz, Humildade e Serenidade. In: José Renato Nalini (coord.). Uma Nova Ética para o Juiz. São Paulo: RT, 1994, p. 14-15.

380 "Pois bem. Penso que o juiz deve buscar se conhecer enquanto totalidade possível (evidente que conhecer a "totalidade total" é impossível), ou seja, enquanto agente historicamente localizado, apto à transformação e com ciência de sua própria individualidade, até dos mecanismos de seu inconsciente (cada vez mais parece-me indispensável tratamento psico-terapêutico). É que muitas vezes julgamos dando um conteúdo racional (consciente) ao ato decisório quando, em verdade, a real motivação aloja-se no inconsciente. A clareza de tais mecanismos faz com que ocorra certo distanciamento crítico brechtiano entre a angústia da lide e as pessoais do juiz. A resolução da neurose individual faz com que às das partes não alcancem a individualidade do juiz - ou a torne limitadamente suportável. Ao contrário, se o distanciamento não ocorrer, pode acontecer que o juiz esteja julgando a si próprio e não a lide do outro. Ou seja, condena a si, mas quem vai para o presídio é o outro." (Amílton Bueno de Carvalho. O juiz e a jurisprudência - um desabafo crítico. Disponível em: < http://ensaiosjuridicos.wordpress.com/2013/04/11/o-juiz-e-a-jurisprudencia-um-desabafo-critico-amilton-buenode-carvalho/>. Acesso em: 26 out. 2013.

381 "Tão importante quanto os aspectos próprios da justiça feminina (o sentimento do juiz, em face do caso concreto) são as qualidades da justiça masculina (a ordem social trazida pela norma, a qual constitui um traço exclusivo do Direito, entre os outros ramos do saber). Somente com a convivência dessas duas dimensões, presentes em Dikê e Atená, parece ser exeqüível uma prestação jurisdicional fundada na virtude da prudência e, 
Com efeito, "a psicologia junguiana citas as características masculinas, que se baseiam na racionalidade, objetividade, ação, determinação, estruturação, construção concreta e domínio dos acontecimentos e problemas; já as femininas teriam por base a sensibilidade, emotividade, flexibilidade, intuição, receptividade, profunda comunicação e clara aptidão para dar sentido à ação". 382

De fato, a pessoa que contém, dentro de si, o feminino e o masculino equilibrados ${ }^{383}$, tem maior condição de lidar com as diversas situações inusitadas que as relações humanas trazem ao conhecimento dos julgadores; de administrar as situações adversas; de criar alternativas para transpor as dificuldades da função; de conviver harmonicamente com as expectativas dos jurisdicionados sobre seu papel de julgador, sem pretender ser super-herói ${ }^{384}$, e sem se perder na toga ${ }^{385}$.

assim, equilibrada e harmônica." (Lídia Reis de Almeida Prado. O Juiz e a Emoção: aspectos da lógica da decisão judicial. Campinas: Millennium Editora, 2003, p. 134). A respeito da dualidade sexual dos seres humanos, com a convivência do masculino e feminino dentro de cada um de nós, vide: John A. Sanford. Os parceiros invisíveis:o masculino e o feminino dentro de cada um de nós. Tradução de I. F. Leal Ferreira. 10ª ed. São Paulo: Paulus, 2007.

${ }^{382}$ Elizabeth Eliana Schefer. A Liderança Feminina das Magistradas na Prática Jurídica. In: David Zimerman e Antônio Carlos Mathias Coltro (Org). Aspectos Psicológicos na Prática Jurídica. $3^{\text {a }}$. ed. Campinas, SP: Millennium Editora, 2010, p. 57).

383 "A alteridade é o arquétipo da anima na personalidade do homem e do animus na personalidade da mulher, que possibilita o encontro do Eu com o Outro dentro da totalidade ( $\mathrm{self}$ ), em um clima de respeito pelas diferenças. Tem sido vista como arquétipo da democracia, da ciência, da criatividade, do amor conjugal e ao próximo, da decisão judicial feita com justiça. Ao ser ativado, esse arquétipo tende a vivenciar a exuberância matriarcal e a ordem patriarcal, sem ser dominado por elas." (Lídia Reis de Almeida Prado. O Juiz e a Emoção: aspectos da lógica da decisão judicial. Campinas: Millennium Editora, 2003, p. 58).

384 “[...] um juiz-cidadão igual, presente, humano. O que se está buscando é uma nova ética à magistratura e não sua alienada teificação! Que tal se pensar num juiz que chora, sofre, ama e que se contamina pela angústia de seu povo!" (Amílton Bueno de Carvalho. O juiz e a jurisprudência - um desabafo crítico. Disponível em: < http://ensaiosjuridicos.wordpress.com/2013/04/11/o-juiz-e-a-jurisprudencia-um-desabafo-critico-amilton-buenode-carvalho/>. Acesso em: 26 out. 2013.

385 "O ego identifica-se com a persona, fato muito lesivo, porque redunda na ofuscação da consciência por um conteúdo inconsciente. $\mathrm{O}$ magistrado tenta ser divino, sem máculas, incidindo, às vezes, na hybris (descomedimento) de se considerar a própria Justiça encarnada (porque só os deuses julgam os mortais). Esse fenômeno chama-se inflação da persona, que ocorre quando os magistrados de tal forma se identificam com as roupas talares, que não mais conseguem desvesti-las nas relações familiares ou sociais. A inflação da persona causa fragilidade ou rigidez da psique." (Lídia Reis de Almeida Prado. O Juiz e a Emoção: aspectos da lógica da decisão judicial. Campinas: Millennium Editora, 2003, p. 45). A esse respeito, importa registrar o exemplo de uma magistrada, que tomada pela toga, não conseguia despi-la nem para fazer a compra de verduras, frutas e legumes, na feira semanal, o que virou motivo de chacota. Também, aqui, releva dizer que a "Juizite" seria, igualmente, uma forma de apego às vestes talares, na tendência à soberba, arrogância e ao complexo de autoridade. 
Os portadores dessas qualidades equilibradas certamente conseguirão melhor servir à sociedade, pois saberão: a) comunicar com simplicidade ${ }^{386}$, na medida em que não precisam se esconder no tecnicismo extremo que o afasta e blinda da sociedade ${ }^{387}$; b) escutar ativamente, o que significa ponderar o que se ouve, considerar, sem responder reativamente, concedendo conforto e espaço para as pessoas falarem sem qualquer temor reverencial (testemunhas ${ }^{388}$, partes, advogados e etc); c) melhor chefiar seus cartórios, lidando com os serventuários, de forma a considerar os diferentes temperamentos, aproveitando e fazendo uso das peculiaridades de cada um, sempre para obter melhor eficiência no trabalho; d) colocar-se perante o Tribunal ${ }^{389}$, em posição de igualdade e não de submissão, por receio de falta de

386 "Escrever com simplicidade é uma das coisas mais difíceis que existem, pois a tendência natural dos que se
consideram eruditos parece levá-los a complicar um pouco o texto, usar palavras difíceis, citações expressivas,
como se isso significasse valorizar o que escrevem. Puro engano: os melhores redatores sabem escrever bem
simples. [ ... Daí a dificuldade da redação de um texto limpo, claro, simples e direto: a vaidade e o desejo de
mostrar-se culto levam à busca da redação sofisticada, assim como as pessoas que se julgam feias se vestem às
vezes de roupas mais vistosas para disfarçar suas supostas imperfeições físicas [...]" (Alexandre Moreira
Germano. Técnica de Redação Forense. Apostila preparada pelo Desembargador Alexandre Moreira Germano,
em janeiro de 2004, e disponível no DAPRE-1 - Departamento de Administração de Prédios - Gráfica, p.16).

387 "O Judiciário deve atentar para o olhar daquele que lhe dirige a causa, aprimorar a qualidade de suas decisões, não fazendo uso do "juridiquês", o emprego de expressões aparentemente sofisticadas que apenas conferem mistério àquilo que devia ser transparente. É o excesso lingüístico que inviabiliza o controle social e a prevenção geral, quando não a própria prevenção específica (do acusado). [...] Rebuscamentos desnecessários, próprios, aliás, do universo jurídico do Brasil, baseado no segredo do que se alega claro, constroem na sociedade a imagem de um Judiciário lento, desatualizado e arrogante, que não faz a menor questão de ser entendido." (Fausto Martin de Sanctis. Alfaiataria. Disponível em: < http://www1.folha.uol.com.br/opiniao/2013/05/1285407-fausto-martinde-sanctis-alfaiataria.shtml.>. Acesso em: 27 maio. $/ 2013$.

388 "A sociedade brasileira é essencialmente erótica, afetiva e intuitiva. Sua baixa escolaridade impede a maioria, sobretudo os mais humildes, de se expressarem e dialogarem dentro da clareza objetiva da razão. Quando essas pessoas humildes são chamadas a depor como testemunhas diante de um juiz sem calor humano, sua principal reação é de medo e inibição o que limita muito a sua articulação. Esse viés psicológico, frequentemente faz com que esses depoimentos sejam transcritos nos autos, apresentando inadequações e incoerências, que muitas vezes os invalidam. O início do depoimento de uma testemunha, que é antecedido por uma ameaça de prisão no caso de um depoimento falso, já é bastante amedrontador. Isso é aumentado pela Persona desumana do juiz, que assim contribui para limitar e até invalidar, por incoerência e contradição, o depoimento da testemunha. A Persona desumana e pouco afetiva de um juiz é uma deformação histórica, causada pela dissociação materialista do método científico. Não é certo identificarmos essa Persona desumana com a justiça, pois ela pode provocar a inibição das testemunhas e limitar a justiça almejada pelo juiz. Estudando a função psicológica da Persona no relacionamento humano, podemos afirmar que a inclusão do calor humano afetuoso na Persona do juiz, favorece a espontaneidade da testemunha e acrescenta a possibilidade de um julgamento mais profundo e justo de um processo, principalmente na parte centralizada no contraditório." (Carlos Amadeu Botelho Byington. A Moral, a Lei, a Ética e a Religiosidade na Filosofia, no Direito e na Psicologia. Um Estudo da Psicologia Simbólica Junguiana. Palestra proferida no II Encontro Ética para um Juiz - Um olhar externo, na Escola Paulista da Magistratura, em 22/11/2013).

389 "Para se perceber o fascínio alienante que exerce a jurisprudência emergente dos tribunais na postura do juiz singular, há aspectos que ocorrem no seio da "casta judicante" que, ou não têm sido percebidos, ou têm sido sonegados àqueles que não fazem parte da estrutura, mas que merecem ser apreciados. A discussão que aqui se 
promoções ou de receber punições ${ }^{390}$. Enfim, terão condições de serem eles mesmos, ainda que exerçam a digníssima função de julgadores.

Entende-se que para os fins desse trabalho, os apontamentos genéricos acima são suficientes para apontar algumas fragilidades dos concursos, que infelizmente não conseguem prover-se dos mais indicados a tão difícil profissão. Registra-se que tais questionamentos, longe de configurarem crítica, intentam reverenciar tão digna carreira, que desgastada por todas as expectativas da função, estão acabando por adoecer o magistrado, que vive oprimido pelo sofrimento resultante do estresse emocional.

Aliás, Miguel Reale já apontava a responsabilidade do juiz como dramática, invocando sua lembrança de ser humano, como primeiro dever do magistrado na busca de atingir o equiitativo e o justo ${ }^{391}$.

levanta tem por objetivo mostrar o invisível que está atrás da realidade aparente, ambicionando que o ato sentencial forjador da jurisprudência possa ter continente liberatório/criativo e não opressor/repetitivo. Esta relação pai-filho é tão presente que, com incrível freqüência, surgem aqueles que a assumem numa extensão alarmante. Do lado do juiz, o temor reverencial leva-o a ter atitude de subserviência despersonalizante, a ponto de alterar o timbre da voz perante o genitor-tribunal, remeter-lhe presentes, conferir-lhe agrados e elogios vulgares: gera a figura repelente do bajulador. Na outra ponta, o integrante do tribunal, que já foi filho um dia, assume agora a figura do pai a exigir que se o bajule, que se o considere superior. E assim o faz até para justificar sua própria existência: negar a subserviência implica reconhecer que sua história foi doentia (e isso é insuportável). Evidente que tudo passa pelo inconsciente tanto que os magistrados percebem isso, mas nos outros! Nesta relação de família, percebem-se momentos interessantes. Há o juiz que está na infância (que pode perdurar para sempre). Aquele que tem o pai por ídolo, que tem apenas um sonho: agradar o pai. Mais: seu desejo quando "crescer" é ser igual a ele. O número daqueles que permanecem na infância é importante. E qual a forma mais comum de agradar o pai? Aderir sua sapiência, reconhecer a inteligência dele. Seu saber é o que interessa. E como o saber do pai é expresso em acórdãos, seu continente é um: transcrever, sempre e sempre, a vontade-jurisprudência do seu superior. ... Mas nesta relação, outros parecem permanecer na adolescência: querem destruir o pai. Seu inimigo externo, sempre e sempre, é o tribunal. Tudo o que acontece na vida tem um culpado: o tribunal. Mesmo as coisas boas que dele emergem são repudiadas. O tribunal está sempre a perseguir-lhe e proteger o outro, o irmão. Seus acórdãos, mesmo que preciosos, são rejeitados. ... Outros, porém, parecem assumir a maturidade: o tribunal é apenas o tribunal! Tem defeitos, como também virtudes, como qualquer grupo humano. Dele emergem decisões preciosas que merecem ser seguidas e outras não. É composto de alguns competentes e outros não, uns sérios e outros não, uns trabalhadores e outros não. Ou seja, é composto de homens com toda a sua dimensão e como tais, e não como "pais", devem ser vistos. Esse filho chega à real independência do tribunal e segue seu caminho para além da vontade "paterna". Está disposto a ousar e a criar, quer o pai aplauda, quer não. Seu compromisso não é com a carreira, ou agradar o pai, mas sim colocar sua atuação a serviço do jurisdicionado." (Amílton Bueno de Carvalho. O Juiz e a Jurisprudência - Um Desabafo Crítico. Disponível em: < http://ensaiosjuridicos.wordpress.com/2013/04/11/o-juiz-e-a-jurisprudencia-um-desabafo-critico-amilton-buenode-carvalho/>. Acesso em: 26 out. 2013. (destaques do autor).

390 A esse respeito, também se manifesta Alexandre Morais da Rosa, quando diz que a aferição de decisões reformadas pelo Tribunal seria critério para promoção na carreira, tal qual um "programa de milhagem", em que a confirmação da sentença renderia pontos, e a reforma acarretaria a perda. (Decisão no Processo Penal como Bricolagem de Significantes. Tese de Doutoramento apresentada à Universidade Federal do Paraná em 2004, p, 316). 
Portanto, além das sugestões acima, entende-se, na linha do quanto professado por José Renato Nalini, que o concurso deveria possuir como última fase para efetiva aprovação um curso de preparação à carreira. Este curso seria anterior à nomeação, e seria responsável pelo preparo prévio do candidato, de forma a capacitá-lo a enfrentar o dia a dia de ser juiz no Brasil.

Com efeito, diversos são os desafios impostos ao magistrado no enfrentamento diário de todo tipo de conflito. Se a carga já se revela pesada para quem é experiente na função, que dirá àquele que recém empossou-se.

Novamente, com apoio no magistério de José Renato Nalini, não há aprendizado de como ser juiz no Brasil, pois somente após sua posse, é que trabalhará. Diferentemente, ninguém chefia as Forças Armadas sem antes ter percorrido longos anos de carreira e educação especial. O mesmo se diz dos padres, que antes de celebrarem a missa, precisam ser ordenados e, para isso, passam anos no Seminário, estudando filosofia, teologia, noviciado, fazendo votos, renovando votos e etc. Sem contar os diplomatas, que depois de ingressarem na carreira, passam dois anos, no Instituto Rio Branco.

Faz-se necessário que o candidato experimente, vivencie as dificuldades que se deparará no exercício da função, que vão desde desafios materiais a emocionais. Por materiais, além dos acima mencionados, tem-se o acúmulo de processos ${ }^{392}$, o excesso de atribuições ${ }^{393}$, a falta de canais de comunicação, consistente na solidão da função. Enfim, é imprescindível que a realidade da carreira, sem qualquer idealismo e endeusamento, se apresente ao candidato antes de seu efetivo ingresso, a fim de que ele conheça todas as mazelas e dificuldades que se deparará, fazendo escolha consciente de para ela acorrer.

\footnotetext{
391 “A bem ver, a responsabilidade do juiz é dramática, visto como a sentença não se reduz a um simples juízo lógico, porquanto - queiram-no ou não os partidários de uma objetividade isenta - um juízo valorativo, como é o da sentença, não pode deixar de empenhar o juiz como ser humano. Lembrar-se dessa contingência talvez seja o primeiro dever do magistrado, em sua real e legítima aspiração de atingir o eqüitativo e o justo". (Miguel Reale. A Ética do Juiz na Cultura Contemporânea. In: José Renato Nalini (Coord.). Uma Nova Ética para o Juiz. São Paulo: RT, 1994, p. 140).

${ }^{392}$ Deve-se lembrar que com a cultura litigiosa brasileira, atrelada à Constituição Brasileira, que colocou o Judiciário como o exclusivo resolutor de litígios, a tendência é só aumentar.

${ }^{393}$ Engana-se o candidato se imaginar que terá como responsabilidade apenas fazer audiências e sentenciar. Os atributos de juízes são muito mais amplos. Possuem muitas funções burocráticas e administrativas, sendo verdadeiros gestores em seus cartórios. Isso sem contar aqueles que assumem comarcas, em que devem exercer jurisdição laboral, federal, e acumulando com a Infância e Juventude. Fora tudo isso, ainda são chamados a comparecer em eventos, e etc.
} 
Do contrário, só restará aos jurisdicionados conviver com magistrados despreparados, desiludidos, que vivem à espera da aposentadoria, conferindo uma justiça tosca, e sem qualquer criatividade.

A esse respeito, importante mencionar que "O Estado de São Paulo implementou experiência pioneira, lamentavelmente não mantida. Por ela, os candidatos aprovados em aprova inicial de concurso de ingresso na Magistratura eram matriculados de ofício no Curso de Preparação à Carreira de Juiz, ministrado pela Escola Paulista da Magistratura. Para prosseguir no concurso de ingresso, o candidato deveria apresentar certificado de conclusão, com aproveitamento, do Curso de Preparação. Iniciativa bem intencionada. Todavia, a natural substituição dos transitórios detentores dos cargos de mando não permitiu chegasse a ser bem implementada. Críticas baseadas no elitismo, gastos excessivos, perda de candidatos ao Ministério Público e afugentamento dos candidatos já egressos de outras carreiras, fizeram com que, antes de verdadeiramente experimentado o sistema, fosse ele abandonado."394

Como visto, esta etapa, que bem contribuiria com a escolha vocacionada da função judicante, foi abolida do concurso, antes mesmo de sua implementação.

E nesse cenário de desamparo ao aspirante a juiz, só se pode esperar das Escolas da Magistratura que compensem esse despreparo, suprindo o recém ingressante a seus quadros desta carência original, acolhendo-o, para o fim de prover-lhe apoio material e emocional, condizentes ao desvendar de tão necessária função.

Para esse mister, as Escolas da Magistratura, na esteira de tudo quanto já exposto acima, deverá, mais que propiciar contínuo ensino técnico-jurídico aos novatos, empreender por outros territórios, cruzar fronteiras, para trazer novas visões, acompanhando as vicissitudes da sociedade, e com isso promover a possibilidade de reciclagem existencial dos seus alunos (magistrados). ${ }^{395}$

\footnotetext{
394 José Renato Nalini. Perspectivas da Justiça e do Juiz no limiar do Século XXI. Tese de doutoramento apresentada à Universidade de São Paulo, em 2000, p. 160.

${ }^{395}$ Em recente entrevista ao Consultor Jurídico, o atual Diretor da Escola Paulista da Magistratura de São Paulo, desembargador Armando de Toledo, esclareceu que o curso que o juiz recebe depois de passar no concurso não se restringe mais ao continuo aperfeiçoamento no Direito. A formação inicial, em São Paulo, visa, atualmente, ensinar os novatos a ser um juiz na prática. Nestes cursos, são ensinados como se lidar com as partes, como fazer audiências, como o juiz deve sentenciar, onde deve pegar referências, como ele tem que se relacionar com o Ministério Público. Da entrevista, vê-se que, não obstante todo o progresso, ainda não há, nestes cursos, programação que objetive capacitar os recém magistrados para uma auto-reciclagem existencial. (Disponível em:
} 
Aqui também, renova-se a sugestão de incorporação de dinâmicas, grupos vivenciais, grupos de reflexão, nos quais os magistrados possam ter espaço para colocar suas angústias, suas dúvidas, receios, e também dividir suas alegrias, seus sucessos, de forma que seja possível saudável troca de experiências, privilegiando-se as virtudes que todos possuem, e tirando disso exemplos a serem seguidos, assim como naquilo que não for bom, instrumentos para possibilidade de cura.

É importante que o magistrado saiba que não está sozinho, e que ele tenha ciência que o problema dele também é o de outro. Necessário que a magistratura se sensibilize que não é uma carreira imune às intempéries inerentes aos humanos, e que por isso, que abra este espaço de compartilhamento de misérias e de êxitos, e acolha seu material humano, de forma a garantir-lhe o devido apoio que o mantenha feliz, satisfeito, íntegro, e, por fim, interessado a entregar à sociedade o seu melhor. ${ }^{396}$

Como visto, o caminho é longo. A nosso ver, necessárias muitas mudanças, quiçá utópicas, para se alcançar a tão sonhada reforma judicial.

< http://www.conjur.com.br/2013-nov-10/armando-toledo-diretor-escola-paulista-magistratura > Acesso em: 11 nov. 2013).

396 “Inspirar-se em outras experiências não é demasia. Ao contrário, pode ser aprendizado. O primeiro preconceito a ser vencido, portanto, é o da autossuficiência. Natural que o ser humano chamado a ser juiz e recrutado para servir ao Judiciário pela porta larga, mas árdua, do concurso público, venha a se sentir uma criatura especial. Ultrapassou um certame severo, enfrentou uma barreira de obstáculos que exigiu estudos, concentração, memorização de um acervo enciclopédico de informações. Toda a legislação, a doutrina e a jurisprudência era lícito presumir que ele dominasse." (José Renato Nalini. A Responsabilidade do Juiz na Condução Racional do Processo. Revista da Escola Nacional da Magistratura, Brasília, Escola Nacional da Magistratura, ano VII, n 6, 2012, p. 448.) 


\section{CONCLUSÃO}

A presente dissertação questionou a previsão da conduta social e da personalidade, do artigo 59 do Código Penal Brasileiro, como critérios orientadores aos magistrados, para fixação da pena-base entre o mínimo e o máximo, por possibilitarem, mediante a inferência em aspectos estritamente subjetivos dos réus, o incremento do poder discricionário, quiçá arbitrários dos julgadores.

Abordando o conceito dessas circunstâncias judiciais tanto na Doutrina quanto na Jurisprudência, o resultado do estudo revelou a excessiva carga moral que ainda orienta sua análise.

Procurou-se evidenciar, outrossim, a impossibilidade de afastar a subjetividade das decisões judiciais, uma vez que os julgadores não conseguem se desvencilhar de seus recortes e contextos de vida, não havendo, portanto, que falar em neutralidade nos julgamentos.

Ponderou-se que a criação recebida desde a infância é voltada para a desconsideração do que é original em cada indivíduo, enfatizando-se o valor da padronização, de forma a buscar-se fora o referencial para balizamento de conduta; o que confrontaria com a previsão das circunstâncias conduta social e personalidade, cujo objetivo é pesquisar a interioridade dos réus.

Para tanto, no Capítulo $1^{\circ}$, elegeu-se o pensamento de Luigi Ferrajoli como modelo, uma vez que referido autor trabalha, tanto em termos de direito processual penal como em termos de direito penal, com o garantismo, que pressupõe a estrita legalidade.

No Capítulo $2^{\circ}$, fizeram-se breves considerações às diversas finalidades da pena, não com o intuito de eleger uma, mas com a pretensão de evidenciar que nenhuma justifica a manutenção das condições judiciais subjetivas conduta social e personalidade.

Nesse mesmo capítulo, procurou-se mostrar que a própria doutrina revela o moralismo que circunda tais circunstâncias, não havendo critérios seguros a diferenciar o que sejam conduta social, personalidade e antecedentes.

Em sede do terceiro capítulo, mediante a análise de julgados do TRF3, do TJ-SP e do STJ, tentou-se comprovar a hipótese inicial de que realmente as condições pessoais abrem 
ainda mais margem ao arbítrio e à falta da desejável segurança jurídica. Aliás, essa falta de critérios verificou-se até mesmo com relação às circunstâncias objetivas.

A fim de reforçar a convicção de que as circunstâncias pessoais devem ser afastadas da aplicação da pena, no quarto capítulo, com fulcro em trabalhos desenvolvidos por profissionais das mais diversas áreas, tentou-se mostrar que os julgadores não estão emocional e psicologicamente preparados para fazerem uma incursão nos aspectos subjetivos dos acusados.

Aliás, poucos profissionais estariam, haja vista as falhas de uma educação voltada para o externo, pautada na cultura da separação, que desconsidera e atropela as particularidades de cada um.

É muito importante deixar claro que todo este trabalho foi permeado pela certeza de que a neutralidade absoluta é impossível; cabe consignar que tal neutralidade sequer seria desejável.

No entanto, dadas imperfeições humanas e a magnitude do Direito Penal do Fato, cabe ao estudioso do Direito Penal buscar criar critérios e, por conseguinte, fechar as diversas brechas existentes para o arbítrio e para a própria projeção das sombras dos responsáveis pelo julgamento de seus semelhantes. 


\section{REFERÊNCIAS}

ALAGIA, Alejandro et al. Direito Penal Brasileiro: teoria geral do direito penal. Rio de Janeiro: Revan, 2003.

AMARAL, Pablo Luiz. Da mitigação do art. 42 da lei 11343/2006 em face da realidade sombria enfrentada pelas "mulas" do tráfico. Disponível em: <http://www.conteudojuridico.com.br/artigo,da-mitigacao-do-art-42-da-lei-113432006-emface-da-realidade-sombria-enfrentada-pelas-mulas-do-trafico,42097.html>. Acesso em: 09 ago. 2013.

ANJOS, Fernando Vernice dos. Análise crítica da finalidade da pena na execução penal: ressocialização e o direito penal brasileiro. Dissertação (Mestrado em Direito). Faculdade de Direito, Universidade de São Paulo, 2009.

AZEVEDO, David Teixeira. Tipicidade e consequência jurídica do crime. Tese (LivreDocência em Direito). Faculdade de Direito da Universidade de São Paulo, 2013.

BACIGALUPO, Enrique. Direito Penal: parte geral. Tradução de André Estefam. São Paulo: Malheiros, 2005.

BAQUEIRO, Fernanda Ravazzano Lopez. As funções não declaradas da ressocialização e a tentativa do discurso legitimador. Ciências penais, São Paulo, ano 6, n. 11, jul./dez. 2009.

BATISTA, Nilo. Introdução crítica ao direito penal brasileiro. 4. ed. Rio de Janeiro: Revan, 1999.

BECCARIA, Cesare. Dos Delitos e das Penas. Tradução de Torrieri Guimarães. São Paulo: Editora Martin Claret, 2004.

BENFICA, Francisco Vani. Da lei penal, da pena e sua aplicação, da execução da pena. Rio de Janeiro: Forense, 1995.

BITENCOURT, Cezar Roberto. Tratado de Direito Penal: parte geral. São Paulo: Saraiva, 2013. 
BOITEUX, Elza Antonia Pereira Cunha. Educação e Valores Ambientais. In: BOITEUX, Elza Antonia Pereira Cunha (Coord.). Direitos Humanos: estudos em homenagem ao Professor Fábio Konder Comparato. São Paulo: Editora Jus Podivm, 2010.

BRACCO, Bruno Amabile. Carl Jung e o Direito Penal. Rio de Janeiro: Editora Lumen Juris, 2013.

BRUNO, Aníbal. Direito Penal: parte geral. Tomo I. Rio de Janeiro: Forense, 2003.

BYINGTON, Carlos Amadeu Botelho. A Moral, a Lei, a Ética e a Religiosidade na Filosofia, no Direito e na Psicologia. Um Estudo da Psicologia Simbólica Junguiana. II Encontro Ética para um Juiz - Um olhar externo,São Paulo, Escola Paulista da Magistratura, em 22/11/2013.

CAPEZ, Fernando. Curso de Direito Penal: parte geral. volume 1. São Paulo: Saraiva, 2002.

CARVALHO, Amilton Bueno de. Personalidade não pode prejudicar cidadão: atenuantes podem deixar a pena abaixo do mínimo: prescritibilidade da medida de segurança. Boletim do IBCCRIM, São Paulo, n. 129, Agost. 2003.

- O juiz e a jurisprudência - um desabafo crítico. Disponível em: < http://ensaiosjuridicos.wordpress.com/2013/04/11/o-juiz-e-a-jurisprudencia-um-desabafocritico-amilton-bueno-de-carvalho/>. Acesso em: 26 out. 2013.

CARVALHO, Olavo de. O Mínimo que você precisa saber para não ser um idiota. $5^{\mathrm{a}}$ ed. Rio de Janeiro: Record, 2013.

CARVALHO, Salo de. Garantismo e direito de punir: teoria agnóstica da pena. Disponível em:

<http://www.grupos.com.br/group/cienciascriminais8/Messages.html?action=download\&year $=10 \&$ month $=6 \& \mathrm{id}=1276553255444592 \&$ attach $=$ Garantismo+e+direito + de + punir + SALO + DE +CARVALHO.doc>. Acesso em: 15 dez. 2013.

-------. Antimanual de criminologia. $5^{\mathrm{a}}$ ed. São Paulo: Saraiva, 2013.

CERVINI, Raúl. Os processos de descriminalização. São Paulo: RT, 2002.

CHOPRA, Deepak et al. O Efeito Sombra. Tradução de Alice Klesck. São Paulo: Lua de Papel, 2010. 
CINTRA, Adjair de Andrade. Prescrição penal e finalidades da pena. Dissertação (Mestrado em Direito). Faculdade de Direito, Universidade de São Paulo, 2007.

COLLE, Juliana de Andrade. Critérios para a valoração das circunstâncias judiciais (art. 59, do CP) na dosimetria da pena. Disponível em: 〈http://jus.com.br/artigos/6232>. Acesso em: 13 set. 2013.

COLTRO, Antônio Carlos Mathias. Juiz, humildade e serenidade. In: NALINI, José Renato (Coord.). Uma Nova Ética para o Juiz. São Paulo: RT, 1994.

. Uma Visão Humanística na Prática Judiciária. In: ZIMERMAN, DAVID; COLTRO, Antônio Carlos Mathias (Orgs.). Aspectos Psicológicos na Prática Jurídica. $3^{\mathrm{a}}$. ed. Campinas, SP: Millennium Editora, 2010.

CORREA JUNIOR, Alceu; SHECAIRA, Sérgio Salomão. Teoria da Pena: finalidades, direito positivo, jurisprudência e outros estudos de ciência criminal. São Paulo: RT, 2002.

CORREIA, Eduardo Henriques da Silva. A teoria do Concurso em Direito Criminal: I unidade e pluralidade de infrações: II - caso julgado e poderes de cognição do juiz. Almedina: Coimbra, 1983.

COSTA, Fernando José da; COSTA JUNIOR, Paulo José da. Curso de direito penal. 12. ${ }^{\text {ed. }}$. São Paulo: Saraiva, 2010.

COSTA, Helena Regina Lobo da. A dignidade Humana: teorias de prevenção geral positiva. São Paulo: RT, 2008.

. Direito Penal Econômico e Direito Administrativo Sancionador: ne bis in idem como medida de política sancionadora integrada. Tese (Livre-Docência em Direito). Faculdade de Direito, Universidade de São Paulo, 2013.

COSTA, José Américo Abreu. A Presença da Sombra na Sentença Criminal. In: ZIMERMAN, DAVID; COLTRO, Antônio Carlos Mathias (Orgs.). Aspectos Psicológicos na Prática Jurídica. 3ª ed. Campinas, SP: Millennium Editora, 2010.

COSTA, José de Faria. Linhas de Direito Penal e de Filosofia: alguns cruzamentos reflexivos. Coimbra: Coimbra Editora, 2005.

COSTA JÚNIOR, Paulo José da. Curso de direito penal. São Paulo: Saraiva, 2009. 
COUTINHO, Jacinto Nelson de Miranda. Jurisdição, Psicanálise e o Mundo Neoliberal. In: COUTINHO, Jacinto Nelson de Miranda et al. Direito e Neoliberalismo: Elementos para uma Leitura Interdisciplinar.Curitiba: EdiBEJ, 1996.

CUNHA, Rosa Maria Cardoso. Metodologia do Ensino Jurídico, Reflexões sobre a Necessidade de sua Sistematização. In: WARAT, Luiz Alberto; CUNHA, Rosa Maria Cardoso. Ensino e Saber Jurídico. Rio de Janeiro: Eldorado Tijuca, 1977.

CYMROT, Paulina. Nossas Lembranças: Guardam Intimidade com as Ficções e São Sempre Fontes Suspeitas? In: ZIMERMAN, DAVID; COLTRO, Antônio Carlos Mathias (Orgs.). Aspectos Psicológicos na Prática Jurídica. 3ª . ed. Campinas, SP: Millennium Editora, 2010.

DELMANTO, Celso et al. Código Penal Comentado. 7. a ed. Rio de Janeiro: Renovar, 2007.

DIAS, Jorge de Figueiredo. Direito Penal: parte geral: tomo I: questões fundamentais: a doutrina geral do crime. São Paulo: RT; Portugal: Coimbra Editora, 2007.

Liberdade, culpa e direito penal. Coimbra: Biblioteca Jurídica Coimbra, 1983.

DIVAN, Gabriel Antinolfi. Decisão judicial nos crimes sexuais: o julgador e o réu interior. Porto Alegre: Livraria do Advogado Editora, 2010.

EAGLEMAN, David. Incógnito: as vidas secretas do cérebro. Tradução de Ryta Vinagre. Rio de Janeiro: Rocco, 2012.

EKMAN, Paul. A linguagem das emoções. Tradução de Carlos Szlak. São Paulo: Lua de Papel, 2011.

ESPÍRITO SANTO, Ruy Cesar do. Uma aula sobre si mesmo. Disponível em: <http://www.educacional.com.br/entrevistas/entrevista0065.asp >. Acesso em: 27 nov. 2013.

.Transdisciplinaridade e autoconhecimento. Disponível em: 〈http://cetrans.com.br/artigos/Ruy_Cezar_do_Espirito_Santo.pdf>. Acesso em: 27 nov. 2013. FACCHINI NETO, Eugênio. E o Juiz não é só de Direito...' (ou ‘a Função Jurisdicional e a Subjetividade'). In: ZIMERMAN, DAVID; COLTRO, Antônio Carlos Mathias (Orgs.). Aspectos Psicológicos na Prática Jurídica. 3ª ed. Campinas, SP: Millennium Editora, 2010.

FALCÃO, Pedro Máximo Paim. A Ética do Magistrado. In: NALINI, José Renato (Coord.). Uma Nova Ética para o Juiz. São Paulo: RT, 1994. 
FALCÓN Y TELLA, Fernando; FALCÓN Y TELLA, Maria José. Fundamento e finalidade da sanção: existe um direito de castigar? Tradução de Claudia de Miranda Avena. São Paulo: RT, 2008.

FERRAJOLI, Luigi. Direito e Razão: teoria do garantismo penal. Tradução de Ana Paula et al. São Paulo: RT, 2002.

FERRARI, Eduardo Reale. Medidas de segurança e direito penal no Estado Democrático de Direito. São Paulo: RT, 2001.

FERRAZ, Esther Figueiredo. A Ética do Juiz. Formação Básica e Vida Familiar. In: NALINI, José Renato (Coord.). Uma Nova Ética para o Juiz. São Paulo: RT, 1994.

FERRAZ JR., Tercio Sampaio. Filosofia do Direito: do perguntador infantil ao neurótico filosofante. In: ALVES, Alaor et al. O que é a filosofia do direito? Barueri, SP: Manole, 2004. FRAGOSO, Heleno Cláudio. Lições de Direito Penal: parte geral. Rio de Janeiro: Forense, 2003.

FRANCO, Alberto Silva; STOCO, Rui (coords.). Código Penal e sua Interpretação: Doutrina e Jurisprudência. $8^{\text {a }}$ ed. São Paulo: RT, 2007.

FRANK, Jerome. Law \& the Modern Mind. Transaction Publishers. New Brunswick (USA) and London (UK).

GARCIA, Basileu. Instituições de direito penal. volume I. tomo II. $7^{\mathrm{a}}$ ed. São Paulo: Saraiva, 2008.

GEBRIM, Patrícia. Gente que mora dentro da gente. São Paulo: Pensamento, 2004.

GERMANO, Alexandre Moreira. Técnica de Redação Forense. Apostila preparada pelo Desembargador Alexandre Moreira Germano, em janeiro de 2004, e disponível no DAPRE-1 - Departamento de Administração de Prédios - Gráfica.

GIACOMOLLI, Nereu José; DUARTE, Liza Bastos. O mito da neutralidade na motivação das decisões judiciais: aspectos epistemológicos. Revista da Ajuris. Porto Alegre, Ajuris, ano XXXIII, n. 102, 2006.

GOFFMAN, Erving. Manicômios, prisões e conventos. Tradução de Dante Moreira Leite. $5^{\mathrm{a}}$ ed. São Paulo: Editora Perspectiva, 1996. 
GOMES, Mariângela Gama de Magalhães. O princípio da proporcionalidade no Direito Penal. São Paulo: RT, 2003.

. Direito Penal e interpretação jurisprudencial: do princípio da legalidade às súmulas vinculantes. São Paulo: Atlas, 2008.

GRECO, Rogério. Curso de direito penal: parte geral. Niteroi: Impetus, 2008.

GULLAR, Ferreira. Traduzir-se. Na vertigem do dia. Disponível em: < http://www.passeiweb.com/na_ponta_lingua/livros/resumos_comentarios/n/na_vertigem_do_ dia>. Acesso em 20 set. 2013.

GUTMAN, Laura. A maternidade: e o encontro com a própria sombra. Tradução de Luís Carlos Cabral. 2a ed. Rio de Janeiro: BestSeller, 2012.

HASSEMER, Winfried. Neurociências e culpabilidade em direito penal. Revista Brasileira de Ciências Criminais, São Paulo, v. 100, 2013. Tradução de Helena Regina Lobo da Costa.

HOLT, John. Aprendendo o tempo todo: como as crianças aprendem sem ser ensinadas. Tradução de Walther Castelli Jr. Campinas, SP: Verus Editora, 2006.

. Como as crianças aprendem. Tradução de Walther Castelli Jr. Campinas, SP: Verus Editora, 2010.

HUNGRIA, Nelson. Comentários ao Código Penal. v. 5. 4ª ed., Rio de Janeiro: Forense, 1958.

JUNG, Carl Gustav. Memórias, Sonhos, Reflexões. Tradução de Dora Ferreira da Silva. Rio de Janeiro: Nova Fronteira, 2006.

KHALIL, Antoin Abou. A personalidade do juiz e a condução do processo. São Paulo: Antoin Abou Khalil, 2011.

KORCZAK, Janusz. Quando eu voltar a ser criança. Tradução de Yan Michalski. São Paulo: Summus, 1981.

LOPES JUNIOR, Aury. Introdução crítica ao processo penal: fundamentos da instrumentalidade garantista. $3^{\mathrm{a}}$ ed. Rio de Janeiro: Lumen Juris, 2005.

LOPES, Jair Leonardo. Curso de direito penal: parte geral. 3. a ed. São Paulo: RT, 1999. 
MACCORMICK, Neil. Argumentação jurídica e teoria do direito. Tradução de Waldéa Barcellos. São Paulo: Martins Fontes, 2006.

MAGALHÃES, Wellington. Por uma revolução democrática da magistratura. Disponível em: < http://blogdofred.blogfolha.uol.com.br/2013/09/10/capacitar-o-magistrado-dos-novostempos/>. Acesso em: 10 set. 2013.

MELIÁ, Manuel Cancio. Psicopatía y Derecho Penal: Algunas Consideraciones Introductorias. Disponível em: 〈http://www.fder.edu.uy/contenido/penal/cancio.pdf >. Acesso: 13 dez. 2013.

MELLO, Lydio Machado Bandeira de. Da capitulação dos crimes e da fixação das penas. 4. ${ }^{\mathrm{a}}$ ed. Belo Horizonte: Bernardo Alvares, 1963.

MENDES, Élio Braz. Aspectos psicopatológicos do ato de decidir. São Paulo, Escola Paulista da Magistratura, em 22.10.2012.

MENESES, Tobias Barreto de. Fundamentos do Direito de Punir. Estudos de Direito. História do Direito Brasileiro. v. 5. Brasília: Senado Federal, 2004.

MILL, John Stuart. Sobre a Liberdade. Tradução de Alberto da Rocha Barros. 2a edição. Petrópolis, RJ: Vozes, 1991.

MIR PUIG, Santiago. Direito penal: fundamentos e teoria do delito. Tradução de Cláudia Viana Garcia e José Carlos Nobre Porciúncula Neto. São Paulo: RT, 2007.

NALINI, José Renato. Formação do Juiz. In: NALINI, José Renato (Coord.). Formação Jurídica. São Paulo: RT, 1994.

. O juiz e a ética no processo. In: NALINI, José Renato (Coord.). Uma Nova Ética para o Juiz. São Paulo: RT, 1994.

- Perspectivas da Justiça e do Juiz no limiar do Século XXI. Tese (Doutorado em Direito). Faculdade de Direito, Universidade de São Paulo, 2000.

. O Juiz e o Acesso à Justiça. 2a . ed. São Paulo: RT, 2000.

- A Responsabilidade do Juiz na Condução Racional do Processo. Revista da Escola Nacional da Magistratura. Brasília, Escola Nacional da Magistratura, ano VII, n 6, 2012. 
. A Rebelião da Toga Revisitada. APAMAGIS, São Paulo, 29/08/2013.

- II Seminário Ética para o juiz: um olhar externo (Org.). Escola Paulista da Magistratura, São Paulo, 22/11/2013.

NUCCI, Guilherme de Souza. Individualização da Pena. 2a ed. São Paulo: RT, 2007.

. Manual de Direito Penal: parte geral: parte especial. $3^{\text {a }}$ ed. São Paulo: RT, 2007.

OLIVEIRA, Edmundo. O Tráfico de Pessoas. $1^{\circ}$ Fórum Mundial Sobre Crime, a Segurança e as Metas da ONU para o Novo Milênio, São Paulo, 06/08/2013.

PASCHOAL, Janaina Conceição. Segurança pública - poder e dever de todos. Das políticas de segurança pública às políticas públicas de segurança. São Paulo, Ilanud, 2002.

PIERRAKOS, Eva; DONOVAN Thesenga. Não Temas o Mal: o método pathwork para a transformação do eu inferior. Tradução de Sérgio Luiz dos Reis Lassere. São Paulo: Editora Cultrix, 2010.

PRADO, Lídia Reis de Almeida. O Juiz e a Emoção: aspectos da lógica da decisão judicial. Campinas: Millennium Editora, 2003.

. Luz e sombra na gênese dos direitos humanos. In: NALINI, José Renato; CARLINI, Angélica (Coord.). Direitos Humanos e Formação Jurídica. São Paulo: Forense, 2010.

_. Racionalidade e Emoção na Prestação Jurisdicional. In: ZIMERMAN, David; COLTRO, Antônio Carlos Mathias (Orgs.). Aspectos Psicológicos na Prática Jurídica. $3^{\mathrm{a}}$. ed. Campinas, SP: Millennium Editora, 2010.

QUADROS, Carmen Silvia de Oliveira. O Estudante de Direito. In: ZIMERMAN, David; COLTRO, Antônio Carlos Mathias (Orgs.). Aspectos Psicológicos na Prática Jurídica. $3^{\mathrm{a}}$. ed. Campinas, SP: Millennium Editora, 2010.

REALE, Miguel. A Ética do Juiz na Cultura Contemporânea. In: NALINI, José Renato (Coord.). Uma Nova Ética para o Juiz. São Paulo: RT, 1994. . Filosofia do direito. 20ª ed., São Paulo: Saraiva, 2002.

REALE JR, Miguel. Razão e subjetividade no direito penal brasileiro. Ciências Penais, São Paulo, ano 1. n. 00, 2004. 
. Instituições de direito penal: parte geral. 3. ${ }^{\mathrm{a}}$ ed. Rio de Janeiro: Forense, 2009.

ROCHA, Fernando A. N. Galvão da. Aplicação da pena. Belo Horizonte: Del Rey, 1995.

Direito Penal: curso completo: parte geral. 2a ed. Belo Horizonte: Del Rey, 2007.

RODRIGUES, Anabela Miranda. A determinação da medida da pena privativa de liberdade. Coimbra: Coimbra, 1995.

RODRÍGUEZ, Víctor Gabriel. Fundamentos de Direito Penal Brasileiro. São Paulo: Atlas, 2011.

ROSA, Alexandre Morais da. Decisão no Processo Penal como Bricolage de Significantes. Tese (Doutorado em Direito). Faculdade de Direito, Universidade Federal do Paraná, 2004.

ROUSSEAU, Jean-Jacques. Confissões. Tradução dos livros I a X de Rachel de Queiroz; livros XI e XII de José Benedicto Pinto. Bauru, SP: Edipro, 2008.

SÁ, Alvino Augusto de. Criminologia Clínica e Execução Penal: proposta de um modelo de terceira geração. São Paulo: RT, 2011.

. Parecer sobre a sentença em primeira instância que condenou E.P.A.T. Disponibilizado pelo autor. Parecer não publicado.

SAINT-EXUPÉRY, Antoine de. O pequeno príncipe: com aquarelas do autor. Tradução de Dom Marcos Barbosa. Rio de Janeiro: Agir, 2009.

SALVADOR NETTO, Alamiro Velludo. Finalidades da pena, conceito material de delito e sistema penal integral. Tese (Doutorado em Direito). Faculdade de Direito, Universidade de São Paulo, 2008.

SANCTIS, Fausto Martin de. Alfaiataria. Disponível em: < http://www1.folha.uol.com.br/opiniao/2013/05/1285407-fausto-martin-de-sanctisalfaiataria.shtml.>. Acesso em: 27 maio. /2013.

SANFORD, John A. Os parceiros invisíveis: o masculino e o feminino dentro de cada um de nós. Tradução de I. F. Leal Ferreira. 10ª ed. São Paulo: Paulus, 2007. 
SCHEFER, Elizabeth Eliana. A Liderança Feminina das Magistradas na Prática Jurídica. In: ZIMERMAN, David; COLTRO, Antônio Carlos Mathias (Coord.). Aspectos Psicológicos na Prática Jurídica. 3ª . ed. Campinas, SP: Millennium Editora, 2010.

SCHMIDT, Ricardo Pippi. Administração Judiciária - Seleção e Formação de Juízes Propostas de Alterações na Resolução no 75 do Conselho Nacional de Justiça. Revista da Escola Nacional da Magistratura. Brasília, Escola Nacional da Magistratura, ano VII, n. 6, novembro, 2012.

SHECAIRA, Sérgio Salomão. Criminologia. São Paulo: RT, 2004.

- Pena e política criminal. A experiência brasileira. In: SÁ, Alvino Augusto de; SHECAIRA, Sérgio Salomão (Orgs.). Criminologia e os problemas da atualidade. São Paulo: Atlas, 2008.

SIQUEIRA, Galdino. Tratado de direito penal: parte geral. tomo II. Rio de Janeiro: José Konfino, 1947.

SOUZA, Carlos Aurélio Mota de. As Tendências Contemporâneas da Ideologia e Práticas Jurídicas. In: ZIMERMAN, David; COLTRO, Antônio Carlos Mathias (Coord.). Aspectos Psicológicos na Prática Jurídica. 3a . ed. Campinas, SP: Millennium Editora, 2010.

As Escolas de Direito no que Tange ao Preparo Psicológico. In: ZIMERMAN, David; COLTRO, Antônio Carlos Mathias (Coord.). Aspectos Psicológicos na Prática Jurídica. $3^{\mathrm{a}}$. ed. Campinas, SP: Millennium Editora, 2010.

SOUZA, Marcelo Soares de. Lombroso entre nós: a perspectiva da personalidade como critério de aumento de pena no direito brasileiro. Boletim do IBCCRIM, ano 19, n. 299, dezembro, 2011.

STEFAM, André. Direito penal 1. São Paulo: Saraiva, 2010.

STERN, Willian. Psicologia geral. Tradução de Fritz Berkemeier. Lisboa: Fundação Calouste Gulbenkian, 1981.

STOCO, Tatiana de Oliveira. A Personalidade do Agente na Fixação da Pena. Dissertação (Mestrado em Direito). Faculdade de Direito, Universidade de São Paulo, 2013. 
SUANNES, Adauto Alonso. Os fundamentos éticos do devido processo penal. São Paulo: RT, 1999.

. Justiça \& Caos. Curitiba: Instituto Memória, 2008.

TANGERINO, Davi de Paiva Costa. Culpabilidade. Rio de Janeiro: Elsevier, 2011.

TEIXEIRA, Sálvio de Figueiredo. Ensaios. A Universidade: Compromisso com a excelência e instrumento de transformação. In: Ministro Sálvio de Figueiredo Teixeira: Homenagem. Brasília: Superior Tribunal de Justiça, 2007. 410 p. (Coletânea de Julgados e Momentos Jurídicos dos Magistrados no TFR e STJ ; 51).

TELES, Ney Moura. Direito penal: parte geral. São Paulo: Atlas, 2006.

THOMAZ, Ana. Desescolarização. São Paulo, Morada da Floresta, 11/5/ 2011.

TOLEDO, Armando Sérgio Prado de. Para presidir tribunal é preciso vocação, não antiguidade. Disponível em: < http://www.conjur.com.br/2013-nov-10/armando-toledo-diretor-escolapaulista-magistratura > Acesso em: 11 nov. 2013.

TOLEDO, Francisco de Assis. Princípios básicos de direito penal. $5^{\mathrm{a}}$ ed. São Paulo: Saraiva, 1994.

WARAT, Luiz Alberto; CUNHA, Rosa Maria Cardoso da. Ensino e Saber Jurídico. Rio de Janeiro: Eldorado Tijuca, 1977.

WARAT, Luis Alberto. Surfando na pororroca: ofício do mediador. MEZZAROBA, Orides et al (Coord.). Florianópolis: Fundação Boiteaux, 2004.

ZAFFARONI, Eugenio Raúl; PIERANGELI, José Henrique Pierangeli. Manual de direito penal brasileiro: parte geral. $2^{a}$ ed., São Paulo: RT, 1999.

ZIMERMAN, David. Uma Aproximação Entre o Perfil da Figura do Juiz de Direito e a do Psicanalista. In: ZIMERMAN, David; COLTRO, Antônio Carlos Mathias (Coord.). Aspectos Psicológicos na Prática Jurídica. 3a . ed. Campinas, SP: Millennium Editora, 2010. 